\title{
LOS TÓPICOS, LAS IDEAS COMUNES Y EL AUTOR \\ UN EJEMPLO EN FRAY LUIS DE LEÓN
}

Memoria de Licenciatura realizada bajo la dirección del Profesor José María Becerra Hiraldo 
MEMORIA DE LICENCIATURA

ROBERTO CASTILLA PÉREZ 


\section{INTRODUCCIÓN}

A la hora de realizar este estudio que va a ser nuestra memoria de Licenciatura queremos ofrecer lo más claramente posible el manuscrito 2846 de la Biblioteca Nacional de Lisboa, págs. 61-132, que es en las que se ofrece el comentario espiritual del Cantar de los Cantares, y del cual todavía no había ninguna edición, ya que la realizada por José Manuel Blecua recoge la primera parte únicamente.

Para ello comenzamos realizando la transcripción del texto, modernización de las grafias y corrección de las citas bíblicas que aparecian en el manuscrito, ya que en su mayoría estaban equivocadas.

Una vez presentado el texto de forma clara se nos planteaba la duda de si realmente sería Fray Luis el autor del texto, ya que hasta ahora nadie lo había trabajado, y además Blecua no lo menciona siquiera en su estudio.

Para tratar de demostrar la autoría del texto decidimos que lo mejor era llevar a cabo un estudio comparativo de este manuscrito con otros textos de los que tuviésemos absoluta seguridad que sí pertenecian a Fray Luis. Y esto es lo que ofrecemos en las páginas siguientes, un estudio de los contenidos del texto que ofrece el P. Merino en su recopilación de las Obras completas de Fray Luis de León, comparado con el texto que ofrece el texto que aqui ofrecemos. Para que el ver paralelismo que existe entre los dos textos de una forma más clara, hemos optado por ofrecer en doble columna todos aquellos pasajes, que son muchos, en los que los textos son identicos, y comentamos únicamente el contenido del resto, que en la mayoría de los casos es también el misnıo, aunque con otras palabras.

El estudio está precedido de un breve capítulo en el que se expone la vida y el proceso inquisitorial sufrido por Fray Luis de León.

A este capitulo le sigue otro en el que se analiza la transmisión de la obra del Cantar de los Cantares desde la época de Fray Luis hasta la actualidad. Y, por último, se ofrece un catálogo con los manuscritos más importantes que se conocen del 
Comentario al Cantar de los Cantares de Fray Luis de León. Después de esto se da inmediatamente paso al estudio comparativo de los contenidos.

\section{VIDA Y PROCESO DE FRAY LUIS DE LEÓN.}

Fray Luis de León nació en Belmonte en agosto de 1527, siendo el primogénito de! matrimonio formado por Lope de León e Inés de Varela. Luis fue el primero los seis hijos. Sus hermanos Cristóbal y Miguel llegaron a ser venticuatros de Granada (el padre vinculó una hacienda en cada uno de ellos). Otro, Antonio, fue sacerdote, pero murió siendo joven. Una hermana, Mencia de Tapia, casó con Francisco de Arévalos, de Hellín; la otra, María de Alarcón casó con el doctor Diego López de Jaramillo.

La fecha exacta del nacimiento de Fray Luis se ha discutido mucho. La crítica apoyándose en algunas razones, se inclina hacia el año 1528, por el epitafio que copió Herrera en el siglo XVII, en el que afirma que murió el 23 de agosto de 1591, a los sesenta y cuatro años de edad.

Lo que sabemos de los primeros años de Fray Luis es muy poco. Vivió en Belmonte hasta los cinco o seis años de edad y ya había comenzado a aprender la lectura y el canto con un maestro, cuando en 1533 acompañó a su padre a Madrid y luego a Valladolid. Lope de León destacó rápidamente en la corte como abogado y, así, en 1541 se le otorga el importante cargo de Oidor de la Cancillería de Granada. Esto aseguraba ya al primogénito una vida acomodada; pero él decidió servir a la Iglesia.

Entre la familia de Fray Luis y el convento de Salamanca existía algún lazo de unión, el célebre agustino Fray Luis de Montoya, que había nacido en Belmonte en 1497 y que había salido hacía pocos años de Salamanca acompañando a Juan III. Fray Luis de León profesó en el convento agustino de San Pedro el 29 de enero de 1544.

El fallecimiento del P. Vitoria en 1546 y la candidatura del célebre P. Cano para sucederle en ia cátedra de Prima de Teología, señalan el acceso de Fray Luis a las aulas de la prestigiosa Universidad de Salamanca. No es posible que asistiera a las clases de Vitoria, ya que todo estudiante de Teología tenía que cursar antes las artes, y esto lo hizo Fray Luis en el convento agustino con Fray Luis de Guevara. Sí asistió a 
las clases del P. Cano y sintió más profundamente que nadie la persuasiva influencia del gran dominico, gracias al cual Fray Luis, antes de que Cano fuese a Trento, habia logrado importantes progresos en exégesis bíblica. Estuvo en Alcalá dieciocho meses no consecutivos, asistiendo e impartiendo clases y en 1557 visitó Toledo, donde se graduó de bachiller por su Universidad.

En mayo de 1557 Fray Luis asistió al Capítulo que los agustinos celebraron en Dueñas, y el discurso en latín que pronunció se hizo célebre en los anales de la orden. Las noticias de tan elogiable discurso llegaron hasta Granada y su padre las recibió con gran alegría.

En 1558 voivió a Salananca incorporando a la Universidad el grado que había conseguido en Toledo. Eran días de tristeza en Salamanca por la quema de un fraile del convento de San Esteban, al ser acusado de hereje.

No sabemos nada de Fray Luis en el transcurso del año de 1559, en el que parece que vivió dedicado a sus estudios. Ya en 1560 se gradúa de maestro y licenciado en Teología. El 30 de junio de este mismo año, y junto a Fray Luis de Guevara, su buen amigo, recibió el grado de Maestro en Sagrada Teología. Este fue el último que concedió el célebre Domingo de Soto, sucesor de Cano en Salamanca, que rnurió el 15 de noviembre de 1560 . Por entonces también murieron dos sabios que habían ejercido gran influencia sobre nuestro fraile: Melchor Cano y Cipriano de la Huerga, cuya oración fúnebre pronunció el belmontino en la Catedral.

Consiguió el agustino la cátedra de Santo Tomás con gran dolor por parte de los dominicos, contra los que pronunció Fray Luis de León una plática aludiendo a la herejía latente descubierta en su orden. En este mismo año de 1561 fue cuando tradujo al castellano el Cantar de los Cantares, que tanto había de dar que hablar a su autor y a todo ei mundo.

En 1562 murió su padre y Fray Luis vino a Granada a visitar a su madre, pasando antes por Valladolid para exponer a los inquisidores, Grijelmo y Riego, que tenía en su poder un libro que le trajo de Italia Arias Montano y que él lo estaba comentando. Todo ello estuvo propiciado por los escrúpulos que suscitó en Fray Diego Rodríguez este libro. 
A partir de este momento las nubes se cernían, cada vez más densas, sobre Fray Luis. Las denuncias las recibía León de Castro en el convento de San Esteban, y éstas las realizaban los estudiantes, como el hijo del Marqués de Mondéjar, contra los "maestrillos" liberales Grajal, Martínez y Luis dee León.

En los primeros meses de 1572 fueron arrestados Grajal, Martínez y Fray Luis de León, produciendo esto una gran sorpresa en Salamanca por ser hombres muy conocidos y queridos. El maestro León pasó la noche de' 26 de marzo en casa de González, y al día siguiente llegó a la cárcel inquisitorial de Valladolid.

El 31 de marzo, cuatro días después de su prisión, pidió que le enviasen desde su convento un crucifijo, un cuadro de la Virgen, las obras de San Agustín, las de San Bernardo, el Libro de Oración de Fray Luis de Granada, unas disciplinas, algunos polvos "para mis melancolías y pasiones del corazón", que una monja llamada Ana de Espinosa hacía para él, un candelero de bronce y un cuchillo para "cortar lo que como". Todos estos deseos fueron satisfechos debido a la quebrantada salud del fraile.

En estos momentos, primeros de su encarcelamiento, sus pensamientos eran muy variados e incesantes. Aunque estaba convencido de que no era culpable. no podía dejar de pensar que su vida de estudio había sido inútil, habiendo sacrificado por ella su salud, sus comodidades y su fortuna. Pero lo que más le mortificaba era el saberse inocente y no poder demostrarlo.

Fue el día 5 de abril de 1572 cuando lo interrogaron y lo amonestaron para que dijera la verdad en todo. "Dios es testigo de que no deseo otra cosa", contestó Fray Luis. Después de esto fue devuelto a su celda, a la que se le llevó papel para que comenzara a redactar su defensa. El 13 de abril presentó esta defensa en doce hojas de papel -unas cinco mil palabras-.

El 5 de mayo, el acusador público Diego de Haedo leyó a Fray Luis la acusación formal. Las cinco primeras acusaciones, y la octava, que son las principales, presentaban a Fray Luis como "descendiente de generación de judíos", y se referian a la interpretación de las Escrituras y la autoridad de la Vulgata; en la sexta, se le acusaba de haber traducido el Cantar de los Cantares a la lengua vulgar; en la séptima, se le imputaba creer que la fe bastaba para justificarse, y en la novena, no haber enunciado las proposiciones heréticas de otros. Las acusaciones de más peso que se le 
hicieron fueron las de haber traducido el Cantar de los Cantares al castellano y haber desautorizado la Vulgata.

Después de ieer el fiscal la acusación a Fray Luis y responder éste por escrito, se designó como abogado defensor del fraile al Dr. Ortiz de Funes. Este hombre estaba bastante abrumado de trabajo y, por ello, tuvo que alegrarle tener un defendido tan instruido que fuese capaz de conducir por sí mismo la causa. La defensa del agustino fue, durante el primer año, restringida y clara. Pero, tras pasar un año en la cárcel, el fraile comienza a impacientarse.

Es necesario, en este momento, plantearnos una pregunta, a saber, qué hicieron los amigos de Fray Luis en su favor mientras éste estuvo encarcelado. Parece que consideraron que era más oportuna una discreta presión en ocasiones contadas y en el momento oportuno. Por ello, Benito Arias Montano y Chacón creyeron que podían perjudicarle si avocaban su causa a Roma. Pero lo que sí hicieron fue pedir a Pedro de Fontidueñas, canónigo de Salamanca y conciliar en Trento, que escribiera al cardenal Hosio, explicándole la situación. Portocarrero, que se encontraba en Galicia, influyó mucho para evitar que se diesen tormentos a Fray Luis. El general de la orden agustiniana, Tadeo Guidelli, escribió a su Provincial de España para que influyese en la liberación de ntestro fraile. La Universidad de Salamanca, por su parte, escribió al inquisidor don Pedro Ponce de León, abogando por Grajal, Martínez y Fray Luis. Es muy posible que hubiese otras muchas personas que estuvieran convencidas de la inocencia del fraile agustino, pero, por temor a la Inquisición, no lo defendieron.

Veamos ahora qué esperaban en estos momentos sus acusadores y enemigos. Éstos pensaban que un hombre tan excitable y $\tan$ franco, como era Fray Luis, se comprometiese a sí mismo durante el proceso. Pero. por el contrario, nuestro agustino, no sólo se defendió con gran ingenio, sino que ayuda también a Grajal.

Como vemos, los acusadores de Fray Luis dejaban mucho que desear. Parece ser que lo que les interesaba era mantener alejado al fraile de la Universidad de Salamanca y de la pugna por las cátedras, que antes siempre habían estado en manos de los dominicos. Pero esto es algo muy serio, ya que parece, al menos a nosotros, que es injusto mantener a una persona en prisión por unas razones como éstas. 
Estos acusadores y enemigos del agustino lanzaban acusaciones, algunas veces obligando a alumnos de la Universidad a que las hicieran, que contenían mucha envidia y maldad. Veamos ahora cómo Fray Luis respondió a algunas de ellas. Aunquc estas acusaciones eran secretas, el ingenio del fraile conseguia saber quién era el autor de cada una de ellas. A Fray Bartolomé de Medina respondió, entre otras cosas: "Este testigo depone sus ruines sospechas y ruines entrañas". A León de Castro: "El maestro León de Castro llama judío y judaizante a aquel, y a todos, los que son diferentes de su parescer". En otra ocasión responde al mismo León de Castro: "Digo que este testigo es el maestro León de Castro, hombre notoriamente enemigo mío y de juicio turbado y demas turbada conciencia como se parece este su juicio. Dice que he vuelto con pasión por ciertas personas y debe ser por el maestro Grajal; y para que esto fuese culpa en mi, y no señal de ánimo dañado en $\dot{c}_{1}$, había de mostrar primero que el dicho maestro Grajal fuese mal hombre o que yo hubiese vuelto por él defendiéndole de cosas malas o no debidas".

Con todo esto hemos querido señalar cuán injustas son las acusaciones contra Fray Luis de León y cómo fueron nacidas del odio existente entre estos acusadores hacia el fraile agustino. Además queremos hacer justicia, en este estudio, a un hombre que tuvo la mala fortuna, en su tiempo, de ser un perfecto hebraísta; tener unas ideas muy claras acerca de las necesidades de leer la Biblia en su lengua que tenían los pueblos que hablaban romance; conseguir hacer unas exégesis bíblicas envidiables, ser un incondicional en la defensa de su lengua frente al latín (aspecto de vital importancia en aquellos momentos de vacilación entre el latín y el romance), y otras muchas cosas por las cuales se le encarceló y mantuvo preso durante cinco años.

El día 30 de diciembre de 1576 una gran multitud de caballeros, profesores y distintas clases sociales salieron al encuentro de Fray Luis y lo acompañaron, triunfalmente, hasta la ciudad de Salamanca. Al día siguiente, se reunió el pleno del Claustro de la Universidad y el Comisario del Santo Oficio declaró que el agustino estaba en libertad y que los inquisidores querían que fuese restituido en su cátedra. El martes 9 de enero comenzó a explicar de nuevo en la Universidad, allí había muchos alumnos a los que Fray Luis conocía desde antes del proceso, algunos de los cuales testificaron en su contra. La ocasión que se le ofrecía para aludir a su inocencia y 
criticar duramente a las personas malintencionadas que lo acusaron no podía ser más óptima. Pero nuestro fraile, una vez más, prefirió una estudiada sencillez que produjo mayor efecto. Así pues, comenzó su explicación con las palabras dicebamus hesterna die, es decir, "decíamos ayer".

No sabemos exactamente si Fray Luis de León pronunció realmente estas palabras, pero creemos que no fue así, ya que aquel día, tras su vuelta a las aulas después del encarcelamiento, empezó a explicar un nuevo curso y en una nueva cátedra. Pero esto no tiene mucha importancia, lo que realmente importa es lo que esa frase, real o elaborada por los alumnos después de lo que allí ocurrió, encierra en sí. Todos los oyentes que se reunieron aquel día, amigos y enemigos, esperaban alguna reflexión, por supuesto dura, de Fray Luis acerca de su injusta prisión en las cárceles de la Inquisición. Nuestro agustino, sabedor de todo esto, prefirió iniciar sus clases como si en esos cinco años no hubiese ocurrido nada, provocando, una vez más, la ira de sus enemigos.

En el año 1578 Fray Luis participa en la reforma del calendario ante la petición del Papa León XIII a la Universidad de Salamanca; además, en ese mismo año, gana la cátedra Filosofia Moral y se gradúa de Maestro en Artes.

El año siguiente, 1579, consigue, tras la muerte del obispo de Segovia, Gregorio Gallo, la cátedra de Sagrada Escritura para la que compitió con un hijo de Garcilaso de la Vega, Fray Lomingo de Guzmán.

El año 1580 Fray Luis poseía una de las tres clases de Escritura en propiedad y explicaba el libro del Eclesiastés y, en este mismo año, vio publicada su obra In Cantica Canticorum junto con el comentario en latín del Salmo XXVI. Además, en este tiempo, explica sobre la Epístola a los Tesalonicenses, el Salmo LXVII y sobre el capítulo 32 del Deuteronomio.

En 1582 el agustino es, de nuevo, denunciado a la Inquisición por herético, ya que había defendido la teoría de Montemayor acerca de la predestinación: los méritos de Jesucristo durante su vida sobre la tierra.

De 1582 a 1585 Fray Luis publica sus primeras obras en español, La Perfecta casada y la primera parte de De los nombres de Cristo. En 1582 se celebró el capítulo 
de Dueñas en el que Fray Luis es elegido Dsfinidor de su orden. Viaja a Madrid para representar a su Universidad en un pleito y vuelve a finales de Julio de 1585.

En el bienio 1586-88 asiste al Capítulo que los agustinos celebran en Burgos. Es enviado, de nuevo, a Madrid para continuar representando a la Universidad de Salamanca en el litigio con el Colegio del Arzobispo; vuelve a Salamanca a informar a la Junta de Comisarios la marcha del litigio ?/ regresa a Madrid donde cae enfermo.

En los años 1588-89 edita las obras de Santa Teresa. Revisa también las cuentas del Provincial de Castilla y vuelve, en agosto de 1589 a Salamanca con el Real Decreto en el que se disponía que los grados sólo fueran conferidos en presencia del número de profesores que dispongan los Estatutos de la Universidad.

El período de 1590-91 lo pasa Fray Luis muy ocupado, ya que tiene que defender a las monjas carmelitas de los abusos del tirano Provincial Fray Nicolás de José María Doria. Termina la Exposición de Job y es elegido Provincial de su orden en Madrigal el 14 de agosto de 1591, sólo nueve días después, el 23 de agosto moriría en Madrigal de Altas Torres y fue enterrado en Salamanca.

\section{TRANSMISIÓN DE SU OBRA SOBRE EL CANTAR DE LOS CANTARES}

Queremos plantear en este apartado, en primer lugar, cuál fue el origen de esta obra y, después, cómo se ha transmitido hasta nuestros días. A lo largo de los cuatro siglos que nos separan del siglo XVI se han barajado varias posibilidades acerca del origen de esta obra. Por un lado, unos piensan que la Exposición del Cantar de los Cantares se produjo a raíz de la petición que hizo a Fray Luis de León la monja del convento salmantino de Sancti Spiritus, Isabel de Osorio, prima del fraile, que deseaba desentrañar la trama literaria y la base alegórica del libro bíblico, ya que ella no podía hacerlo por su desconocimiento del latín. Cuando ella ia hubo leído y meditado se la devolvió al agustino, el cual la guardó bajo llave, libre de las miradas de todos menes de la de un joven fraile que estaba encargado de organizar su celda, Fray Diego de León. Éste, tras leerla. se dedicó a copiarla, comenzando así una amplia dispersión de manuscritos sacados del original.

Otros estudiosos creen que la idea de llevar a cabo esta obra fue propiciada por el encuentro que tuvieron Fray Luis y su amigo Benito Arias Montano, que le comentó, a 
raíz de una obra que éi traía de Italia, la posibilidad de trasladar al castellano el texto bíbiico. A esta hipótesis se opone el hecho de que las últimas investigaciones pueden afirmar que cuando se produjo ese encuentro Fray Luis había iniciado ya su obra.

Estas dos posibilidades son perfectamente válidas, pero creemos que, al menos, la primera puede tratarse más de un recurso literario que de otra cosa, ya que resulta bastante increíble que una obra tan rigurosa en las explicaciones vaya destinada a un uso particular. Por el contrario, parece más sensato creer que es una obra nacida del conocimiento extraordinario que tenía Fray Luis de la Exégesis bíblica y por la necesidad, que él tan bien intuyó, de un acercamiento en castellano a un texî̀ tan complejo como era el Cantar de los Cantares por su lengua y estructura original.

A partir de su realización, como ya hemos dichc, las copias se dispersaron por España, Portugal y alguna liegó incluso a Cuzco. Al principio los manuscritos pasaron de unas manos a otras y en algunos momentos podemos fácilmente perderles la pista.

En el año 1798 se publica en Salamanca en la imprenta de Francisco de Toxar el texto de la Traducción literal y declaración del libro de los Cantares de Salomón hecha por el maestro Fray Luis de León. También es importante, así como anterior, la recopilación de las obras completas de Fray Luis que llevó a cabo Gregorio Mayans en 1762 y donde también se recoge este Comentario.

Pero cuando realmente se produce un gran avance en el tratamiento de esta obra a la hora de su publicación es cuando en 1804 la presenta el P. Merino dentro de una edición de las Obras Completas de Fray Luis de León. Este clérigo había cotejado diez manuscritos que se encuentran en la Academia de la Historia y que pasan por ser los más cercanos a la versión original de la obra, alguno de ellos corregido por el mismo Fray Luis.

A partir de este momento se han seguido recopilando las obras completas de nuestro agustino, pero ya todas estas recopilaciones y acercamientos al comentario del texto bíblico se realizan a partir del cotejo llevado a cabo por el P. Merino, añadiendo muy pocas cosas. En este grupo de ediciones se encuentran las del P. Félix García, el P. Ángel Custodio Vega y el P. Blanco García, entre otros. Pero todos estos clérigos y otros muchos críticos no se han limitado exclusivamente a editar las obras de Fray Luis, sino que son autores de multitud de trabajos acerca del hallazgo de nuevos 
documentos y crítica textual de estas obras, sobre todo la referida al texto de los Cantares de Salomón. En los últimos años, este tipo de estudios críticos han seguido desarrollándose. tratando de llevar a los lectores este comentario del libro bíblico de la forma más clara posible e incluso buscando nuevas interpretaciones.

Muy recientemente, y como muestra de la vigencia que todavía hoy tienen Fray Luis de León y su Comentario, ha aparecido una nueva edición y estudio de esta obra, llevada a cabo por José Manuel Blecua, y que coteja la edición del P. Merino y el Manuscrito 2846 de la Biblioteca Nacional de Lisboa en su Comentario según la letra, sin hacer ninguna referencia al Comentario según el sentido espiritual que es el que nosotros aquí ofrecemos.

Como vemos, la figura de Fray Luis de León, de toda su obra y, sobre tode, del Comentario del Cantar de los Cantares, no ha dejado de tener importancia y vigencia a lo largo de estos cuatro siglos y, con seguridad la seguirá teniendo.

Después de haber hablado de la transmisión textual dei comentario al Cantar de los Cantares no queremos terminar este apartado sin hacer una reflexión sobre ia localización en Lisboa de nuestro manuscrito. Podíamos haber tomado el camino más corto y haber expuesto que dicho texto se hallaba en la Biblioteca Nacional de Lisboa porque sí, o porque no estaba en ninguna otra, al igual de los manuscritos de las obras de otros autores se han encontrado en los lugares más insospechados sin existir una obligada relación entre el autor $\mathrm{y}$ dicho lugar.

Leyendo el volumen $\mathrm{X}$ de la Colección de Documentos inéditos para la historia de España, el cual recoge el proceso inquisitorial instruido a Fray Luis de León, nos apareció una posible pista que nos vinculaba al agustino con Portugal; se trata el dominico Francisco Foreiro. Este fraile, según afirma el mismo Fray Luis durante el proceso, le había enviado una carta felicitándole por su traducción y comentario al Cantar de los Cantares. La carta la había enviado a través de un deudo que él tenía en el convento dominico de San Esteban en Salamanca.

La pista era buena, pero había algo que no cuadraba: cómo un dominico felicita a un agustino por su trabajo y, precisamente, a través de otre dominico, además, de! convento de San Esteban. Pero tras la lectura de algunos textos de la época, nos dimos cuenta rápidamente de que era posible sin ningún tipo de problema por varias 
cuestiones. En primer lugar, las relaciones hispano-portuguesas eran muy buenas, especialmente en lo que a cultura se refería. En segundo lugar, las relaciones entre los conventos eran aún más cordiales en la época, sin importar la orden a la que pertenecían. Además, las mitificadas polémicas entre los conventos de San Esteban y San Agustín, en Salamanca, no existieron siempre ni tampoco todos los frailes se odiaban mutuamente. Por otra parte, Francisco Foreiro pudo conocer, más o menos directamente, a Fray Luis de León, ya que el primero estuvo un corto período de tiempo en Salamanca al volver del Concilio de Trento, antes de profesar en la Orden de Santo Domingo de Coimbra.

Una vez establecida esta posible relación creímos necesario un estudio lingüístico y paleográfico que nos diese más claridad sobre el asunto. Una vez obtenidas las conclusiones de estos estudios nos dimos cuenta de que, realmente, el Comentario del Cantar de los Cantares en castellano pudo haberlo leído Francisco Foreiro, ya que de lo contrario pondríamos en duda las palabras de Fray Luis en el proceso, aunque no tenía por qué ser nuestio manuscrito; más aún, no debió ser nuestro manuscrito el que leyó Foreiro debido a la imposibilidad de fecharlo antes de 1580, año en que murió el dominico. Todo ello nos llevó a plantear una segunda hipótesis, y era que, tras haber leído Francisco Foreiro el texto y ante la petición de Fray Luis de todos los manuscritos dispersos para aportarlos al proceso, éste lo devolviera, no sin antes haber hecho una copia, por el interés que podía tener dicho texto para un experto escriturista como era Foreiro, máxime con lo frecuente que era hacer este tipo de cosas en la época, ya que el mismo Fray Alonso Gudiel tenía una copia hecha por él misrio de esta obra, según nos narra Aubrey Bell en su obra Luis de León. Un estudio del Renacimiento español'. Así pues, de la copia realizada por Foreiro se habrían sucedido otras, una de las cuales sería la nuestra.

\footnotetext{
1. Aubrey Bell. Luis de León. Un estudio del Renacimento español. Araluce, Barcelona, 1927, pág. 227. Es un excelente estudio sobre la figura de Fray Luis de León en el que su autor nos demuestra su gran conocimiento de la cultura española del XVI, en general, y de Fray Luis de León, en particular. Aún así la informacion que ofrece en la nota a pie de página no la hemos podido comprobar, ya que debió confundir su fuente porque la noticia del manuscrito que poseia Gudiel no aparece en Documentos inéditos para la historia de España, X, 365, como él dice.
} 


\section{MANUSCRITOS}

Nos proponemos ahora, antes de culminar este apartado, presentar la referencia bibliográfica de los manuscritos más importantes que se conservan de la obra de Fray Luis de León, bien sea er. recopilaciones de obras completas, en recopilaciones parciales, o en las que sólo aparece el Comentario del Cantar de los Cantares.

I. Ms. D. 6. 15. De la Angélica, de Roma. Contiene la Espositio in Psalmun XXXVI, In Cantico Canticorum explanatio, ambas de Fray Luis de León, y otros trabajos de los padres Guevara y Antolínez, los dos catedráticos e hijos del convento agustino de Salamanca.

II. Ms. De la Academia de la Historia. $4^{\circ}$, forrado en pergamino, con paginación incompleta. Copia de varias manos. Tiene estos tratados:

- In Ecclesiastem (incompleto).

- In Canticum Moysis. Fragmento autógrafo, coil muchas correcciones.

- In Psalmum XV (completo).

- In Psalmuin XVI (completo).

- In Psalmum XVII (incompleto).

- In Psalmum CXLV (incompleto).

- In Psalmum XXVIII (completo).

- Exposición de los Cantares. En castellano.

- De utriusque Aqui typici.., ejemplar impreso de la edición salmantina de 1592.

III. Ms. De la Academia de la Historia. $4^{\circ}$, encuadernado en pergamino. En el lomo lleva el siguiente rótulo: Papeles pertenecientes a la causa del M. Fr. Luis de León. Es copia de varias manos y contiene estos opúsculos:

- Exposición de los Cantares (copia en castellano) 
- De Vulgata editione. Extracto autógrafo que hizo Fray Luis de León de su lectura: De Sacra Scriptura. Está suscrito por los doctores Velázquez, Barriovero y Balvás.

IV. Ms. de la Academia de la Historia. Obras de..., $4^{\circ}$, de fines del siglo XVI, o principios del XVII. Este manuscrito es el famoso de San Felipe el Real, "que examinó aprisa y malamente el dicho Coster", escribe Astrana Marín.

V. Ms. De la Academia de la Historia. Exposición del libro de los Cantares. Letra parecida a la de Fray Luis de León.

VI. Ms. de la Biblioteca del Conde-Duque. La Exposición sobre los Cantares, según la letra. En $8^{\circ}$.

VII. Ms. 1717 de la Biblioteca de Barcelona. Exposición de los Cánticos de Salomón. Folios 1-105. Expossitio litteralis et mistica. Inc.: Es tan grande y tan insaciable el desseo del enamorado, que ninguna cosa le satisfaze... Papel del siglo XVII, 107 folios útiles menos el $105 \mathrm{v}^{\circ}$., más cuatro hojas al principio y una al final, que están en bl. S. n. 175 x 115 mms. Letra española. Apostillas marginales, de la época. Notanda: en el primer plano se entrelee: Exposición de los cánticos de Salomón. Manuscrito. Expositor anónimo. En la hoja primera hay varios ejercicios escolares. El cántico $8^{\circ}$ es casi idéntico al de la Exposición de los Cantares de Fray Luis de León.

VIII Ms. Es el códice 2846 de la Biblioteca Nacional de Lisboa, descubierto por Klaus Reinhardt del que dio noticia en el diario $\mathrm{ABC}$, 29-8-91, pág. 47 y ss. Letra del siglo XVI, 129 fols. En el folio 1 se lee Exposición sobre el cantar / de los cantares de Salomon segun / el sentido de la letra, por el / maestro Fray Luis de Leon / de la Orden de S. Aug. / Cathedratico de / Theologia / en Sala / manca. En el folio 61 comienza la versión espiritual: Prohemio sobre la Exposición de los Cantares de Salomon por el P. F. Luis de Leon. Segun el sentido espiritual. El mismo Klaus 
Reinhardt escribe: "Esta exposición espiritual tiene las siguientes características: en primer término se apoya muy estrechamente en la exposición literal de $156^{\prime}$, repitiéndoia literalmente en algunos pasajes o abreviándola. En algunos casos la Exposición espiritual incluso revisa la literal y la continúa. También en cuanto al texto bíblico, la Exposición espiritual no siempre adopta la Exposición literal, sino que la modifica utilizando para este fin variantes que se encuentran ya en la exposición literal o en otros escritos de Fray Luis".

IX. Palencia, Biblioteca Capitular, Ms. 55 (s. XVI), f. îr-70v: Cantares del Maestro f. Luis de León. Inc: “Ninguna cosa es mas propria a dios ...”. Falta el último folio; el texto termina con las palabras: «... hacellas a tiempo que el se saue y tiene señalado que es el de el ju<icio>n. El manuscrito lleva muchas notas marginales; en parte dan para cada versículo del Cantar de los Cantares el texto de la Biblia vulgata latina; en parte ponen una palabra en castellano que indica y resume el contenido de la exposición correspondiente.

X. Toledo, Biblioteca pública, Ms. 260 (s. XVIII), p. 1-208. Sin nombrar al autor ni el título. Al dorso: Sobre el libro del Cantar de los Cantares. El manuscrito contiene el texto íntegro. Inc.: “Prólogo. Ninguna cosa es mas propia a Dios...”. Expl: “... a quien propia y solamente se debe toda gloria por los siglos de los siglos. Amen".

XI. Toledo, Biblioteca Pública, Ms. 299, f. 3r-164r: Cantar de los cantares de Salomon por el maestro Fr. Luis de León del Orden de San Agustin Doctor Theologo y cathedratico de la Universidad de Salamanca. f. 1-2 en blanco. Escritura de fines del siglo XVIII o principios del siglo XIX. Incipit y Explicit como en Ms. 260 descrito arriba. En f. 3v se encuentra de mano posterior la nota: "En este año de 1798 se ha impreso en Valencia (sic!) la obra presente y se anunció en la página 664 de las Gazetas de Madrid. En el año de 1806 se ha reimpreso en Madrid en el tomo $5 .^{\circ}$ de las Obras del mismo Fr. Luis". 


\section{BIBLIOGRAFÍA}

\section{EDICIONES}

- León, Fray Luis de, Del maestro Fray Luis de León la Exposición del Cantar de los Cantares de Salomón según la letra, en Obras completas, VI, 1804, págs. 1-292. Edición del P. Merino.

- León, Fray Luis de, Cantar de los Cantares de Salomón, Gredos, Madrid, 1994. Edición y estudio de José Manuel Blecua.

- León, Fray Luis de, De los nombres de Cristo, 3 vols., Clásicos Castellanos, Espasa-Calpe, Madrid, 1969. Edición y prólogo de Federico de Onís.

- León, Fray Luis de, Poesía completa, Libros Río Nuevo, Barcelona, 1989. Edición y prólogo de Miguel de Santiago.

\section{OBRAS DE CONSULTA}

- Alborg, J. L., Historia de la literatura española, vol. I, Gredos, Madrid, 1980.

- Alcina Franch, J., y Blecua, J. M., Gramática española, Ariel, Barcelona, 1989,

- Corominas, J. y Pascual, J.A., Diccionario Crítico Etimológico Castellano e Hispánico, Madrid, Gredos, 1984.

- Covarrubias, S., Tesoro de la lengua castellana, Madrid, 1674.

- Díez Borque, J. M., Comentario de textos literarios, Playor, Madrid, 1988. 
- Jones, R. O., Siglo de oro: prosa y poesía, en Historia de la literatura española, tomo II, Ariel, Barcelona, 1989.

- Lapesa, R., Historia de la lengua española, Gredos, Madrid, 1988.

- Marcos Marín, F., El comentario lingüistico, Cátedra, Madrid, 1990.

- Moliner, M., Diccionario de uso del español, Gredos, Madrid, 1992.

- Real Academia Española, Diccionario de autoridades, 3 vols., Gredos, Madrid, 1963.

- Real Academia Española, Diccionario de la lengua española, Vigésima edición, Espasa-Calpe, Madrid, 1984.

- Sair.z de Robles, F. C., Diccionario español de sinónimos y antónimos, Aguilar, Madrid, 1986.

- Ventura, J., Desde los Reyes Católicos hasta Carlos IV, vol III de Floría, G. (Dir.), Historia de España, Plaza \& Janés, Barcelona, 1976.

\section{ESTUDIOS}

- Alcalá, A., El proceso inquisitorial de Fray Luis de León, Servicio de Publicaciones de ia Universidad de Salamanca, Salamanca, 1991.

- Álvarez Aranguren, L., La gramática española del siglo XVI. Fray Luis de León, Servicio de Publicaciones de la Junta de Comunidades de Castilla la Mancha, Madrid, 1989. 
- Bahner, W., La lingüistica española del siglo de oro, Ciencia Nueva, Madrid, 1966.

- Barrientos García, J., Escritos desde la cárcel. Autógrafos del primer proceso inquisitorial, Real Monasterio del Escorial, Madrid, 1991.

- Bell, A. F., Luis de León. Un estudio del Renacimiento español, Araluce, Barcelona, 1927.

- Fernández Navarro, J., “Amigos y enemigos de Fray Luis de León”, El dia de Cuenca, 28 de enero de 1928.

- Figueiredo, F. De, Pirene. Introducción a la Historia comparada de las literaturas Portuguesa y Española, Espasa-Calpe, Colección Austral, Madrid, 1971.

- Foreiro Ulyssiponensi, F, Iesaiae Prophetae vetus et nova ex Hebraico versio cum commentario in quo utriusque ratio redditur, vulgatus interpres a plurimorum calumniis vindicatur; et loci omnes, quibus sana doctrina adversus haereticos, atque Iudaeos confirmari potest, summo studio, ac diligentia explicantur, Venetiis, ex officina Iordani Zileti, 1563.

- García de la Concha, V. (Dir.), Academia literaria renacentista. I Fray Luis de León, Servicio de Publicaciones de la Universidad de Salamanca, 1979.

- Menéndez Pidal, R., "El lenguaje del siglo XVI", en Cruz y Raya, n VI, 1933, págs. 7-63.

- Montoliú, M., "La lengua española en el siglo XVI", en Miscelánea Nebrija, Revista de Filología Española, ${ }^{\circ} 29,1945$. 
- Reinhardt, K., Bibelkommentare Spanischer autoren (1500-1700), vol. I (A-LL), CSIC, Madrid, 1990.

- Revista Española de Estudios Bíblicos, Málaga, 1928, vol. II (dedicado integramente a Fray Luis de León). 


\section{ESTUDIO DEL CONTENIDO}

Antes de abordar el estudio comparativo del contenido de los dos textos Comentario del Cantar de los Cantares según la letra y Comentario del Cantar de los Cantares según el sentido espiritual, tenemos que comentar algunos aspectos de ambos textos que nos parecen interesantes.

En primer lugar, tenemos que decir que el Comentario según la letra es el que recoge el P. Merino en su recopilación de las obras completas de Fray Luis de León del año 1804, y al que nos referiremos en este estudio como texto $M$.

En segundo lugar diremos que el Comentario según el sentido espiritual corresponden al manuscrito 1846 de la Biblioteca Nacional de Lisboa en el cual aparece este título, así como el nombre del padre Maestro Fray Luis de León. Este manuscrito consta de 193 páginas, pero es en la página 61 donde comienza el comentario según el sentido espiritual que es el que aquí estudiamos. A partir de este momento nos referiremos a este texto como texto $\mathrm{L}$.

Una vez realizadas estas aclaraciones, nos tenemos que plantear qué es lo que vamos a encontrar en cada uno de estos dos textos si partimos de los títulos. Ambos, como sus títulos indican, son comentarios al libro bíblico del Cantar de los Cantares aunque con algunas diferencias, ya que $\mathbf{M}$ se ciñe a la letra y por ello será un comentario más formal, de aciaración de términos oscuros del texto, mientras que $\mathrm{L}$ es un comentario con muchos más aspectos literarios y sujeto a las sugerencias que hace al espíritu del lector, o comentarista, la lectura del texto bíblico. Pero todo esto tenemos que entenderlo desde un plano totalmente teórico, ya que en la práctica, como veremos según avancemos en la comparación, los textos van tomando cosas el uno del otro y viceversa confundiéndose de forma clara lo que es comentario espiritual y lo que a la letra se refiere.

Además hay que tener en cuenta que contamos con la autenticidad innegable de uno de los dos textos, $\mathrm{M}$, lo cual nos ayudará y dará bastante luz para llegar al lugar que queremos, a saber, demostrar con el mayor número de datos posibles la autoría de Fray 
Luis de León en el segundo texto, es decir, L, que es lo que tratamos de llevar a cabo con este estudio. Por tanto, las coincidencias en algunos casos y las omisiones, en otros, nos darán suficiente luz para llevar a cabo nuestro propósito.

Dicho todo esto pasamos al estudio comparativo del contenido de ambos textos con la intención de ver cómo afronta cada uno de los textos el comentario del libro sagrado, y analizar, de forma más particular, los párrafos en los que coinciden exactamente ambos textos, que no scn pocos, y los cuales ofreceremos en doble columna para que se vea de forma más clara el paralelismo que existe entre ambos textos.

\section{ESTUDIO COMPARATIVO DE LOS CONTENIDOS}

La exposición del texto bíblico se comienza en los dos textos con un prólogo. En la primera parte existe un gran paralelismo entre los dos textos. Comienzan haciendo una declaración del gran amor que Dios tiene a los hombres y las formas que tiene de demostrárselo a través de la vida, la libertad, el mundo; reconfortándolo en todo momento con su auxilio, al principio, y después con la colaboración del Espíritu Santo. No existe, pues, diferencia notable en el planteamiento del tema del amor de Dios a los hombres entre $\mathrm{L}$ y $\mathrm{M}$, aunque está claro que $\mathrm{M}$ desarrolla más por extenso las ideas con un interés que podriamos denominar pedagógico, para conseguir una aclaración mayor de los puntos que pudieran resultar más oscuros.

Por el contrario, L plantea el tema de una forma más sintética, como si se tratara de una obra destinada a personas ya iniciadas y conocedoras de la manifestación plural del amor de Dios a los hombres.

A continuación se habla de que este amor de Dios, antes expuesto ha sido tratado en muchas partes de la Biblia, pero hay un libro en el que está tratado de manera magistral. Todavía no se da el título del libro en ninguno de los textos, pero ya se advierte que se trata de una "canción suavísima", como la definen ambos textos, que fue compuesta por Salomón y puesta en boca de dos pastores, pastor y pastora, esposo y esposa. 
Llegados a este punto las semejanzas entre $L$ y $M$ no pueden ser mayores y nos encontramos que en la descripción del contenido de la obra ambos textos coinciden exactamente.

Dice L:

"aqui se been pintados al viuo los amorosos juegos de los diuinos amantes. los ençendidos deseos, los perpetuos cuidados, las rezias congoxas que la ausençia y el temor que en ellos causan juntamente con los celos y sospechas que entre ellos se mueuen, aqui se oye el sonido de los ardientes suspiros mensageros del coraçon, y de las amorosas quexas $y$ dulçes raçonamientos que vnas vezes van vestidos de esperança, otras de temor, otras de tristeza, otras de alegria y en breue todos aquellos sentimientos que los apassionados amantes prouar suelen. aqui se been tarto mas agudas $y$ delicadas, quanto mas viuo $\mathrm{y}$ açendrado es el diuino amor que el humano."

(Texto M, pág. 3-4)
"Aqui se veen pintados al vivo los amorosos fuegos de los divinos amantes, los encendidos deseos, los perpetuos cuidados, iàs recias congojas, que el ausencia, y el temor en ellos causan, juntamente con los zelos, y sospechas, que entre ellos se mueven. Aqui se oye el sonido de los ardientes sospiros, mensageros del corazon, y de las amorosas quejas, $y$ dulces razonamientos, que van unas veces vestidos de esperanza, y otras de temor. $\mathrm{Y}$ en breve, todos aquellos sentimientos, que los apasionados amantes probar suelen, aqui se veen tarto mas agudos, $y$ deiicados, quanto mas vivo, y acendrado es el divino amor, que el mundano."

(Texto L, pág. 104-105)

Continúa la narración quiénes son realmente esos personajes alegóricos, pastorpastora, esposo-esposa. De nuevo, en esta explicación, concuerdan ambos textos y se 
dice que ei pastor-esposo es Dios y que la pastora-esposa es la congregación de los fieles, la Iglesia.

Llama la atención lo que ocurre a partir de este momento en el desarrollo de la exposición de los dos textos. El texto $\mathrm{L}$ después de esta aclaración de los personajes remata el prólogo haciendo algunas, muy breves, indicaciones sobre la lengua hebrea. Por otro lado el texto $\mathrm{M}$ se dedica a explicar pormenorizadamente la metodología seguida en la elaboración de la obra, así como los problemas surgidos, las soluciones adoptadas y otros aspectos. De este modo se habla en $\mathbf{M}$ de la oscuridad característica de la lengua hebrea, de la adaptación a texto en prosa que ha realizado el autor, ya que la obra se "escribió en metro", y, en tercer lugar, de cómo el autor cumple con su función de fiel traductor de la obra "volviendo en nuestra lengua palabra por palabra".

Pero esta diferencia de contenidos de $\mathrm{L}$ respecto a $\mathrm{M}$ pierde su importancia cuando nos adentiamos en el texto y vemos cómo todas estas apreciaciones que $M$ hace en el prólogo, $\mathrm{L}$ las introduce en el momento en que surge en la exposición algún problema derivado de estos aspectos que plantean dificultad a la hora de trasladar un texto de la lengua hebrea a la española. 


\section{CAPÍTULO I.}

Antes de comenzar la comparación de los contenidos hay que decir que el texto $\mathrm{M}$ incluye unas breves aclaraciones acerca de la propiedad de la lengua hebrea de duplicar los términos cuando "se quiere encarecer una cosa". Estas aclaraciones son las mismas que $\mathrm{L}$ hacía en el prólogo, también de forma breve.

Por tanto, haciendo un recuento de los contenidos de la parte comparada hasta el momento nos damos cuenta de que entre $\mathrm{L}$ y $\mathrm{M}$, más que diferencias, lo que hay son cosas en común.

1.- ¡Béseme de besos de su boca!, porque buenos (son) tur amores más que el vino.

Desde que se inicia la exposición, y sobre todo en estos primeros capítulos, vemos cómo algo que advertíamos al principio que podía ocurrir se está manifestando. Estamos estudiando dos comentarios de una misma obra, pero uno de ellos es un comentario según la letra, M, y el otro, L, es según el sentido espiritual. Por tanto si hacemos una lectura ingenua y sin habernos documentado en algunos aspectos acerca de lo que en el texto se entiende por letra y por sencido espiritual, podríamos abundar en la idea de que estamos ante dos textos distintos coincidentes, parcialmente, en el título.

Dicho lo anterior y entrando en los textos, nos damos cuenta de que en ambos se hace una interesante reflexión acerca de los vínculos de unidad que produce el amor, llegándose a unir en uno solo los que antes eran dos. De este modo lo expresa $\mathrm{M}, \mathrm{y}$ añade aún más afirmando que la separación física, que se puede producir en algún momento, tiene consecuencias muy negativas para los amantes.

En los mismos términos se expresan estas cualidades del amor en L, al principio, pero llega un momento en el que se inicia un giro en la explicación. Se inicia, en ese momento, el comentario según el sentido espiritual. Así pues, nos damos cuenta de que, como decíamos al principio, en muchos casos se mezcla el comentario según la 
letra con el espiritual, lo cual nos lleva a pensar que el texto L es más completo que el texto M por abordar el doble comentario al Cantar de los Cantares. Esto que aqui parece una simple conjetura, irá tomando consistencia a lo largo del estudio cuando comprobemos que este dobie comentario se repite en $\mathrm{L}$ en todos los capítuios.

En el texto L la explicación del amor humano, que se da en $\mathrm{M}$, se convierte, al iniciarse este comentario espiritual, en una declaración del amor entre Dios (Esposo) y la Iglesia (Esposa), así como en la relación de mutua dependencia que se establece entre ellos.

\section{Porque tus amores son mejores que el vino.}

El pequeño comentario que se hace de este pasaje es muy rico y muestra las dotes poéticas de su autor. Se hace una comparación entre el amor y el vino, ambos tienen los mismos, efectos, ya que producen plena felicidad en los que hacen uso de ellos y hace olvidar "los trabajos pasados".

Hasta aquí la comparación vino-amor es igual en los dos textos. A partir de este punto el texto $\mathrm{L}$ desarrolla más la comparación y añade un miembro a ese dúo de eiementos con las mismas propiedades; el tercer elemento, como corresponde al sentido espiritual, es Dios, que tiene para el hombre los mismos efectos benefactores que el amor y el vino. Por tanto, vemos como es un pasaje lleno de metáforas y vuelve a plantearse el aspecto de que el texto $\mathrm{L}$ es más rico que el texto $\mathrm{M}$.

2.- Al olor de tus ungüentos buenos. (Que es) ungüento derramado tu nombre; por esto las doncellas te amaron.

Nos encontramos, una vez más, ante un caso de gran coincidencia entre nuestros dos textos. Ambos coinciden en la idea de que la primera frase del versículo no está completa y es propio del lenguaje de los enamorados, que aunque emiten secuencias incompletas, elios las entienden por completo; para completar la primera frase del versículo faltaría decir: "al olor de estos ungüentos yo volveré de mi desmayo".

De nuevo nos encontramos en un texto cargado de imágenes, en el cual se entiende la presencia del amado como una "confección de olor", que hace volver en sí a la amada, que como ya hemos visto, se había desmayado por la ausencia del otro. 
Queda claro que las coincidencias entre $\mathrm{L}$ y $\mathrm{M}$ son bastante llamativas. Vamos a ver ahora las diferencias que existen entre $\mathrm{L}$ y $M$ provocadas, obviamente, por el interés espiriual del primero de ellos. En L la metáfora va más lejos y ese ungüento que da la vida no es sólo el amado, sino que además es Dios, en cuya presencia nos encontramos revividos del desmayo producido por su ausencia. De ahí que todas ias doncellas (todo aquel que quiere volver a Dios) lo quieran conseguir porque el tenerlo supone la felicidad.

\section{3.- ¡Llévame! En pos de ti correremos.}

Vuelve a repetirse una explicación muy pequeña, pero, a la vez, muy rica en cuanto a su contenido. De nuevo los dos textos coinciden en la explicación quedando claro que hay que entenderla en relación con lo anterior. Una vez que semos sido cautivados por el oior de los ungüentos, ahora ya vamos donde nos lleve este amado. Insiste el texto L en ofrecer una triple explicación en la que la Esposa (Iglesia) ha de ser guiada por el verdadero olor de Dios y alejarse de "todas las otras sectas de la gentilidad".

Metióme el rey en sus retretes. Regocijarnos hemos en ti, alegrarnos hemos, membrársenos han tus amores más que el vino. Las dulzuras te aman.

Parece ser que una de las mayores muestras de amor es la confianza. De este modo lo entienden los enamorados que aparecen en nuestros textos. La explicación de este versículo, en su mayor parte, está dedicada a comentar cómo es una gran muestra de amor el que el rey la haya conducido a sus aposentos más íntimos.

Ya en la segunda parte los caminos que se toman para la explicación son bastante distintos. Así, en M se opta por una explicación filológica de este versículo tan largo y que puede interpretarse de varias formas; por ello se proponen distintas puntuaciones a partir de retretes.

Por el contrario $\mathrm{L}$ vuelve a su comentario espiritual y afirma que en estos versos del texto sagrado se ven dos aspectos de la "grandeza y benignidad de Dios". El primero es que Dios nos muestra sus maravillas (sus retretes) y además, en segundo lugar, nos ofrece la esperanza de que si le amamos es posible gozar de esas maravillas, de ese amor íntimo con Dios, de esus retretes. 
4.- Morena yo, pero amable, hijas de Jerusalén, como las tiendas de Quedar, como las cortinas de Salomón.

La apariencia externa no es lo principal a la hora de valorar a las personas y así es manifestado, muy por extenso, en ambos textos. Es considerable la semejanza que existe entre estas dos explicaciones aunque la del texto $\mathrm{L}$ es mucho más pormenorizada. Esta explicación es más extensa porque añade una más, informando de que para llegar a conocer la verdadera belleza interior, no la tez morena, es necesario tener también unos ojos especiales que sepan ver el interior de las personas y no quedarse en lo exterior. Del mismo modo interpretan ambos textos lus ejemplos que pone esta Esposa para demostrar que su belleza es interior y no exterior; estos ejemplos son el compararse con las tiendas de Quedar y con las cortinas de Salomón.

Por último, si faltaba alguna semejanza, ambos textos coinciden en que esta Esposa es la Iglesia y esa morena pigmentación es la mala opinión a la que ésta estaba expuesta en el mundo. Hay que tener en cuenta que ésta es la primera vez que el texto $M$ incluye un comentario espiritual de forma explícita, ya habíamos advertido en la introducción que esto ocurriría.

5.- No me desdeñéis si soy morena, que miróme el sol. Los hijos de mi madre porfiaron contra mí, pusiéronme (por) guarda de viñas; la mi viña no guardé.

Este fragmento viene a justificar el anterior. Se trata de explicar, entre ambos textos, a qué se debe el color de la piel, a qué se debe el que la Iglesia esté tan mal vista en el mundo. La explicación a esto es que los hermanos de la Esposa la pusieron a cuidar su viña, es decir, aquellos que rodean a la Iglesia apartaron a la Esposa de ella para dedicarla a otros menesteres, de ahí que la apariencia exterior de ésta sea fea, aunque ella, en su interior, se ha cultivado para agradar a Dios.

De nuevo los dos textos mantienen una explicación muy parecida de los versos sagrados. En este apartado volvemos a citar dos párrafos idénticos de cada uno de los textos a la hora de explicar la expresión viña mía. Aunque la explicación sea muy parecida en ambos textos, nosotros ofrecemos en doble columna aquellos pasajes que son absolutamente idénticos. 
"y donde dize viña mia en lo hebreo tiene doblada fuerça que dize (mia remia) dando a entender quan suia propia es, y quanto cuidado deue tener dellas".
"Donde dice, mi viña, en el bebreo tiene doblada fuerza, porque dice, mia remia, dando a entender, quan propria suya es, y quanto cuidado debe tener della".

( Texto M, pág. 13 )

( Texto L, pág. 119)

Corno hemos visto ambos textos quedan casi homogeneizados al introducir $\mathbf{M}$ algurios aspectos del comentario espiritual.

6.- Enséñame, joh amado de mi alma!, dónde apacientas, dónde sesteas al mediodia. Que, ¿jor qué andaré yo descarriada entre los rebaños de tus compañeros?

Una vez que ha sido justificada su bondad por parte de la esposa, aún siendo morena de piel, ahora le pide al Esposo que le diga dónde se encuentra para ir a buscarlo, ya que ella no puede permanecer más tiempo con esa angustia. Quiere saber el lugar exacto donde apacienta para llegar directa a él y no perder tiempo buscándolo "de hato en hato".

En todo esto coinciden M y L. A partir de aquí L incluye el comentario espiritual en el cual ese pastor es Dios, que conduce a sus ovejas a los pastos de la Doctrina Cristiana y esta Esposa es la Iglesia que quiere llegar rápidamente a esos pastos. En este caso M vuelve a no hacer mención del comentario espiritual. En este momento tenemos que hacer una precisión que nos ayuda a dar solidez a una teoría antes sólo apuntada. Se trata de la anterioridad cronológica del texto $\mathrm{M}$ y la mayor exactitud en las explicaciones, así como cantidad de las mismas que aporta $\mathrm{L}$ con respecto al anterior. Para esta explicación tenemos que apoyarnos en una frase de los versos bíblicos que introducen este apartado de la exposición. Vamos a mostrar esa frase tal y como aparece en L y M: 
L

“...porque andare yo reboçada por las manadas de tus compañeros"
M

"....porque andare yo descarriada entre los rebaños de tus compañeros?"

(Texto L, pág. 120)

(Texto M, pág. 31)

La palabra clave es "descarriada" que en $M$ se sugiere que es mejor entenderla como "rebozada"; la explicación posterior de este término es semejante en L y en M. Pero lo que a nosotros nos interesa resaltar es que en L ya no se habla de "descarriada" sino que hasta en los mismos versos que introducen la exposición se sustituye por "rebozada". Puede parecer una hipótesis arriesgada pero parece que se puede hablar con cierta seguridad de la continuidad existente de $\mathrm{M}$ a L.

7.- Si no te lo sabes, joh hermosa entre las mujeres!, salte y sigue las pisadas del ganado, y apacentarás tus cabritos junto a las cabañas de los pastores.

Ante las peticiones de la Esposa, el Esposo le da la solución para que lo encuentre y llegue a él. La solución está en que la Esposa salga a apacentar el ganado menor, los cabritos, y éstos por instinto maternal saldrán siguiendo los pasos de sus madres y la llevarán hasta los pastos donde está el ganado mayor y el Esposo.

En el sentido espiritual que expone $L$ se advierte a la Esposa que no ande "por caminos no hollados", sino que siga las huellas de los que han sido sus antepasados y predecesores en la fe.

Por su parte, el texto $M$ incluye, una vez más, el sentido espiritual diciendo que esta interpretación "avisa a las almas justas de dos cosas muy importantes": la primera es que a Dios se le encuentra en todas las manifestaciones de la naturaieza. La segunda es que para llegar a Dios no es necesario buscar nuevos caminos sino seguir "el usado ya y trillado por el bienaventurado ejemplo de infinito número de personas santísimas y doctísimas que nos han precedido".

8.- A la yegua mía en el carro de Faraón te comparo, amiga mía. 
Una vez más nos encontramos un fragmento en el que $M$ prescinde del comentario espiritual. Por su parte, L no prescinde del comentario según la letra y además lo advierte: "porque la letra está revuelta, desmarañémosla primero y luego iremos al sentido".

En el comentario de la letra la semejanza entre ambos textos es bastante importante, sobre todo en la definición de términos como "Faraón", aunque hay que advertir que la descripción de la letra efectuado por $\mathrm{L}$ es más minucioso. Ambos textos llegan a coincidir incluso en las citas bíblicas a las que recurren para ilustrar los comentarios de términos que llevan a cabo.

9.- Bellas están tus mejillas con los cerquillos, tu cuello con los collares.

\section{0.- Tortolicas de oro te haremos con remates de plata.}

Dentro del primer capítulo, éste es el apartado más rico en el comentario según la letra de ambos textos. Se lleva a cabo una muy minuciosa descripción del término "cerquillos" y sus correspondencias españolas. Es una de las mejores descripciones de todo el comentario en la que se hacen múltiples relaciones entre los términos, argumentadas con ejemplos bastante fiables. El culmen de la comparación se produce al relacionar "cerquillos" con tórtolas y con la asociación lógica a la fidelidad de los amantes reflejada en la fidelidad, ya que las tórtolas son los animales que guardan mayor fidelidad cuando se unen en parejas.

El comentario espiritual, que sólo desarrolla $\mathrm{L}$, apunta que todos estos regalos que el Esposo promete a la Esposa son los dones que Dios ofrece a la Iglesia y es necesario que ésta se eduque en la ley y en la doctrina cristiana para llegar a conseguirlos y ser la Esposa (Iglesia) más bella a los ojos de su Esposo (Dios).

\section{1.- Cuando estaba el rey en su recostamiento, el mi nardo dio su olor.}

El comentario según la letra vuelve a ser muy parecido en ambos textos, haciendo una extensa argumentación acerca de las costumbres existentes en Oriente sobre la utilización de los perfumes a la hora de honrar a personas de dignidad. 
El coinentario espiritual se intuye en ambos textos aunque son bastante parcos en la explicación. Dios es digno de que la Iglesia, su esposa, le tribute estas ofrendas olorosas.

12.- Manojuelo de mirra es mi amado a mí. Morará entre mis pechos.

\section{3.- Racimo de copher mi amado a mi de las viñas de Engadi.}

Nos encontramos ante estos dos versículos en los que parece que lo más interesante es "declarar" qué tipo de plantas son las que se nombran y de dónde provienen, aunque en algún caso no se acierte a encontrar un nombre que las defina en castellano. A esto se dedican ambos textos en profundidad.

La conclusión a la que se llega en el texto L, en el comentario espiritual, es que lo mismo que las mujeres gustan de los bálsamos y perfumes, más aún si son apreciados, del mismo modo gusta Dios de su Iglesia y ésta de Él.

Se trata, por tanto, en ambos textos, de un comentario basado, más que en otra cosa, en la aclaración de términos que pueden ser de dificil comprensión.

\section{4.- ¡Oh cuán hermosa eres, amiga mía, oh cuán hermosa! Tus ojos de paloma.}

En estos últimos versículos estamos asistiendo a una explosión de piropos y alabanzas que se envían los esposos. En este apartado, en concreto, de la hermosura global de la Esposa, puesta de manifiesto por esa reiteración de la expresión “ $i O h$ cuán hermosa eres!". Y toda esta belleza general se centra en los ojos, ya que si éstos son bellos todo el cuerpo será bello. Los ojos son el ideal de belleza en la mayor parte de la Sagrada Escritura, y se comparan con los ojos de las palomas, ya que hay una raza de éstas, las tripolinas, que tienen unos ojos bellísimos.

Veamos ahora el comentario a la letra que hacen ambos textos ya que llama la atención por su gran semejanza.

L

"Torna el Esp ${ }^{\circ}$ loar a su Esposa lo qual el conosçe ser sumamente bella fuera de
M

"Loa pues la hermosura de la Esposa, que a su parecer era sumamente bella, $y$ declara ser grande su belleza, usando 
lo que las hijas de Jerusalem pensauan, $y$ assi con esta repetiçion vsada en la sagrada scriptura come hemos dicho declara su belleza ser grande diziendo hermosa eres amiga mia, hermosa eres. dando a entender que del todo sea hermosa, y porque gran parte de la hermosura y perfection esta en los ojos de tal arte que aun`$q$ sea bien dispuesta, $y$ de bellas façiones vna persona si tiene los ojos feos todo se desdora. siendo los ojos instrumento del mas preçioso sentido del hombre y unas ventanas por donde los affectos del anima mas claro se muestran, por esso particularmente despues de auer testificado la tal belleza de su Espa trata de sus ojos, diziendo, tus ojos son de paloma; ay algunas palomas hazia leuante, las quales algunos han traido hazia ca. y llamalas Tropolinas, estas tienen muy hermosos ojos y de un color estraño ^q paresçen fuego viuo."

(Texto L, pág. 130) desta repeticion de palabras que es comun en la sagrada Escritura, diciendo: Hermosa eres, amiga mia, hermosa eres, como si dixera, hermosa, hermosisima eres. Y porque una gran parte de la hermosura esta en los ojos, que son espejo del alma, y el mas noble de todos los sentidos, y que ellos solos si son fens, bastan a afear el rostro de una persona por demas gentiles facciones que sea; por esto particularmente despues de haber loado la belleza de su Esposa en general, hace mencion dellos, $\mathrm{y}$ dice, que son como de paloma. Las que vemos por aca no los tienen muy hermosos, pero sonlo de hermosisimos las de tierra Palestina: que como se sabe por relacion de mercaderes, y por unas que trahen de levante, que llaman tripolinas, son muy diferentes de las nuestras, señaladamente en los ojos, porque los tienen grandes, y muy redondos, llenos de resplandor, y de un movimiento velocisimo, y de un color extraño, que parece fuego vivo."

(Texto M, págs. 44-45)

En el comentario espiritual que hace L esta semejanza de los ojos de la Esposa con la palomas se traduce como "simplicidad y candor cristiano(s) y inocencia de la vida y lealtad en el amor y fe". 
15.- ¡Y tú qué hermoso eres, amado mío, y qué gracioso!; y también el nuestro lecho florido; las vigas de nuestra casa, de cedro; los artesones de ella, de aciprés.

Una vez más existe una gran semejanza entre los dos textos a la hora de explicar la letra, aunque L es más minucioso. Ambos textos están de acuerdo en que la belleza no puede ser solamente exterior sino que también debe ser interior, $y$ que hay personas muy bellas que en "el movimiento de su ánima" pierden toda esa belleza. Por todo esto la Esposa no sólo se refiere a la belleza de su Esposo, sino también a la de las cosas de sus Esposo, es decir, su cama, las vigas de la casa y los artesonados. Esto es lo que expresan tanto L como $\mathrm{M}$.

"Responde la Espa al testimonio de loor ^ $\mathrm{q}$ su Esp $^{\circ}$ açerca de su belleza auia dado conosçiendo y publicando la hermosura del, y porque la belleza no solo esta en la exterior muestra asentada. s. de la proporçion de los miembros, y escogida pintura de naturales colores, mas tambien $y$ principalmente tiene silla en la anima como son andar, mirar, hablar. ets. que sin esta belleza no tiene sal, ni gracia la otra del cuerpo, antes es vna frialdad y menos de amar que una bella ymagen pintada como lo vemos vulgarmente".

(Texto L, pág. 131-132)
"Responde la Esposa, y paga en la misma moneda al Esposo, conociendo, y publicando la hermosura que hay en el: y porque la belleza esta, nc solamerite asentada en la exterior muestra de la buena proporcion de facciones, $y$ escogida pintura de naturales colores, mas tambien $y$ principalmente tiene su silla ex el anima; y porque esta parte de la hermosura del anima se llama gracia, y se muestra de fuera, y se da a entender en los movimientos de la misma anima, como son mirar, hablar, reir, cantar, andar. y los demas, los quales todos en lengua toscana generalmente se llaman atti, de tal manera que sin esta belleza, la otra del cuerpo, es una frialdad sin sal, y sin gracia, y menos digna de ser 
amada, que lo es una imagen, como cada dia se ve"

(Texto M, pág. 45)

En el sentido espiritual, que expresan ambos textos, se afirma que este párrafo es una muestra del "deseo de las almas que aman a Dios y querrían verse con él". Pero es éste un deseo aún imperfecto, ya que quieren traer a Dios hacia ellas y no ir ellas a buscarlo. 


\section{CAPÍTULO II}

1.- Yo rusa del campo y lirio de los valles.

\section{2.- Como lirio entre espinas, asi es mi amada entre las hijas.}

Nos encontramos que en la exposición de estos versículos del texto bíblico existen dos opiniones encontradas en nuestros textos. Mientras $M$ cree que es la Esposa quien recita estos versos, $\mathrm{L}$ afirma que es el Esposo quien los recita en un lógico tú a tú propio del diálogo de elogios que ambos esposos están llevando a cabo. La edición de la Sagrada Biblia preparada por D. Eloino Nácar Fuster y D. Alberto Colunga, O.P., BAC, 1978, Madrid, ponc también en boca ae la Esposa estos versos. Pero no tratamos aquí de averiguar quién dice las cosas sino qué es lo que se dice.

Asistimos, a partir de ahora, a una serie de elogios que se tributan recíprocamente Esposo y Esposa demostrándose en cuánto precio se tienen. Todos estos elogios son referidos a plantas y árboles del campo, tales como la rosa, el lirio, la azucena, etc.

Lo más llamativo son las aclaraciones que se hacen acerca de estas plantas y el valor para referirse a la belleza que podían tener estos elementos para los coetáneos del rey Salomón. Así la rosa del campo tiene más valor que la de la huerta por tener el mérito de crecer sin cultivo; el lirio de los valles goza de una situación privilegiada por estar en las zonas más frescas; por último, el lirio entre espinas es el más bello y meritorio de todos por encontrarse rodeado de zarzas. En todos estos aspectos de interpretación de la letra coinciden $\mathrm{L}$ y $\mathrm{M}$.

Del mismo modo coinciden en lo que se refiere al comentario espiritual, ya que ven en estas plantas la belleza de la Iglesia, pero, a la vez, se dan cuenta de que se encientra rodeada de las zarzas del mal, aunque con la ayuda de la belleza suprema (Dios) consigue sobresalir y resultar mejor que los demás que le rodean.

3.- Como el manzano entre los árboles silvestres, asi el mi amado entre los hijos; en su sombra deseé, sentéme, y su fruto dulce a mi garganta. 
En el comentario de ambos textos a estos versículos se prescinde de la interpretación espiritual, aunque en los dos se alude a ella.

Se compara al Esposo con un manzano, árbol hermoso, lleno de hojas y fruto que invita al descanso bajo sus ramas y a reponer fuerzas comiendo de su fruto. Esto es lo que la Esposa hace y además bajo su sombra rememora los acontecimientos que le han ocurrido junto a su Esposo. Esto es en cuanto al sentido de la letra en el que L y M son casi idénticos.

En cuanto al sentido espiritual ya hemos advertido que se alude de pasada, pero creemos que no es necesario más, ya que en ese Esposo-Manzano se ve claramente la figura de Dios en cuya sombra se cobija la Esposa-Iglesia para descansar y tomar nuevas fuerzas para seguir su camino y para rememorar los hechos que le han ucurrido junto a su amado.

4.- Metióme en la cámara del vino y la bandera suya en mi (es) amor.

5.- Rodeadme de vasos de vino, cercadme de manzanas, que enferma estoy de amor.

Es muy difícil encontrar tanta semejanza entre dos textos que, a juzgar por lo que sus títulos indican, tienen pretensiones distintas. En este apartado L y M coinciden de forma casi absoluta.

Los lazos de unión que crea el amor y la gran confianza que despierta entre los dos amados. Establecida esta confianza la Esposa se deja llevai a la bodega del Esposo y este hecho se supone una tan gran muestra de amor que no tiene por menos que desmayarse y de ahí la segunda frase. Pide vino y ser rodeada de manzanas para volver en sí de su desmayo, ya que está enferma, enferma de amor. Veamos como comentan L y $M$ este segundo versículo:

"y por esso dize. esforçadme con vasos, tened debaxo de mi mançanas que estoi
"Y por la misma causa pide, que la rodeen de manzanas. $\mathrm{Y}$ ansi en decir, 
enferma de amor, en dezir esforçadme se da a entender el desfalleçimiento de la fuerça ^ $q$ se yua a caer, y diziendo. Tened debaxo de mi mançanas, se da a entender que ella estaua ya cayda y recostada, y esto todo al prinçipio del desmaio, y lo que dize. estoi enferma de amor, no es la enfermedad propia del cuerpo, sino vna grande afliçion del aninıo que la imaginaçion de alguna cosa causa, y de aqui se sigue desfalleçimiento de la fuerça del cuerpo." esforzadme, se da a entender el desfallecimiento de su fuerza, que se iba a caer. Y diciendo, tended debaxo de mi manzanas, se colige que ella estaba ya caida, y recostada. Lo que dice, estoy enferma de amor, no es la enfermedad propria del cuerpo, sino una grave afliccion del anima, que la imaginacion de alguna cosa causa, y de aqui se sigue el desfallecer del cuerpo."

(Texto M, págs. 57-58)

(Texto L, pág. 139)

En cuanto al sentido espiritual, que sólo nos ofrece $L$, tenemos que decir que esa Esposa es la Iglesia, que en todo momento se deja llevar por su Esposo, Dios, pues es grande la confianza que entre ellos existe, fruto del amor que se profesan. Y son tan grandes las muestras de amor de Dios que esta Iglesia, asombrada, sufre desmayos, volviendo de nuevo a Dios, a su vino, a sus manzanas, a "los Sagrados Libros", para volver en sí de esos desmayos, muestra clara de su flaqueza.

\section{6.- La su izquierda debajo de mi cabeza y la su derecha me abrace.}

Parece muy normal, y así se muestra en los cuadros, que cuando alguien se desmaya las persona que lo socorre, y más aún si es su amado, sitúe su brazo izquierdo bajo la cabeza del desmayado y el derecho abrazando el cuerpo. Éste es el sentido de la letra de estos versículos y así lo interpretan L y $M$. 
"Prosigue la Enamorada demandando socorro para su desmayo. ningun remedio maior ay para los que se desmayan, que ver junto consigo aquello ^ $q$ ama y que le muestren fauor y le den señales de amor. porque ellos tienen entendido que de alli les viene su trabajo, y de alli mismo les puede venir el aliuio y descanso, por tanto estando ya la Espa caida en el desmayo, dize, 0 , si mi Esp $^{\circ}$ viniesse y debaxo de mi cabeça pusiesse su braço yzquierdo. y con el derecho ciñesse mi cuerpo, estas palabras son figura de vno que tiene abraçada alguna persona $\uparrow q$ se desmaya y la quiere bien sientase, y pone la cabeça del desmayado ençima del su braço yzquierdo, y con el derecho le abraça, $y$ esto hemos de entender que lo dize la Esposa en aquellos interualos del desmaio quando torna en si, como se vee en los ^q tal passion sienten ^q se trasponen $y$ tornen $y$ tornan en si hablando algo de aquella materia que los haze desmayar y luego se tornan a trasponer durando esta batalla $\wedge \mathrm{q}$ la fuerça del coraçon vença aquel contrario humor..."

(Texto L, pág. 140)
"Prosigue la enamurada Esposa demandando socorros para su desmayo. El natural remedio para los que se desmayan de amor, es ver juntos consigo a los que aman, $y$ que les muestren señales de favor, $y$ voluntad, $y$ se conduelan de su mal; porque de alli les viene su trabajo, y de lo mismo les ha de venir su alivio, y descanso. $Y$ ansi la Esposa estando ya caida en el desmayo, pide a su Esposo que llegue a ella, y la sustente, y ciña con sus brazos. Y no fue en esto negligente el Esposo, que visto su desmayo, acudio luego, y la tomo en sus brazos: que se hace conforme, a como ella dice, poniendo el brazo izquierdo debaxo de la cabeza, y abrazandola con el derecho. Y esto hemcs de entender, que lo dixo la Esposa en aquellos intervalos del desmayo, quando vuelve en si; como se ve en los que sienten esta pasion, y se trasponen, y vuelven en si hablando algo de aquello que les duele, y se iornan a trasponer, y dura esta batalla, hasta que se consume el mal humor".

(Texto M, pág. 58) 
Respecto al sentido espiritual L ve en los brazos, derecho e izquierdo, una imagen de la vida terrena y la vida eterna. La mano izquierda es con la que Dios sostiene nuestras cabezas para que en este mundo no lleguen a tocar el suelo. La mano derecha es con la que Dios nos abrazará en la vida eterna cuando hayamos dejado esta vida.

7.- Conjúroos, hijas de Jerusalén, por las cabras y por las ciervas inontesas, si despertáredes y velar hiciérades al amor hasta que quiera.

Una vez que se ha conseguido recuperar a la Esposa de su desmayo, ésta cae en ur profundo sueño. El Esposo pide a los circundantes que por nada despierten a la Esposa, que bajo ningún concepto interrumpan su sueño. Para hacer esta petición emite un conjuro muy apropiado para aquellas mujeres que, al parecer, eran cazadores.

Lo más interesante en este comentario de la letra son las comparaciones que se hacen al aludir a cómo se suelen hacer los ruegos a las personas deseándoles, si los cumplen, que todo les vaya bien. Veamos con qué grado de semejanza analizan estos versículos los dos textos.

"Estas donçellas pareçe que son caçadoras en la conjuraçion ^q el Esp ${ }^{\circ}$ les haze, y es muy conforme a la imaginaçion tomada en este idro porque a la $E p^{a}$ pastorica, las compañeras han de ser rusticas y que tengan exerçiçio del campo, como es ser pastoras, y caçar, y este era vso de tierra de Asia prinç̧ipalmente hazia Tiro, y en aquellas comarcas de Judea que las Virgines exerçitassen en la caça, y assi las requiere, y ajuramenta el Esposo. Diziendo. Ruegoos, y "y estas eran cazadoras, segun parece en la conjuracion, que el Esposo les hace: $y$ es muy conforme a la imaginacion que se prosigue en este libro, porque de la Esposa, que es pastora, las compañeras han de ser rusticas, y que tengan exercicio del campo, como es ser pastoras, y cazar. Y este era uso de la tierra de Asia, principalmente hacia Tiro, $y$ en aquellas comarcas de Judea, que las virgenes se exercitasen en la caza; y ansi las requiere, $y$ juramenta el 
requieroos hijas de Jerusalem ansi os vaia siempre bien en la caza, ansi en la caça, assi gozeys de las çierbas y hermosas cabras montesas que no desperteis a my amada hasta que ella quiera, y de suio se despierte. Esta es comunisima costumbre de todos ios buenos autores $\mathrm{y}$ aun de todas las gentes orar la feliçidad, a desgraçia del estudio y exerçiçio del otro, quando lo quiere rogar algo, o, quando le desea mal, que a vno que estudia dezimos assi Dios os haga vn gran letrado, y a vno ^q pretende dignidades, assi yo os vea un grandisimo, al marinero, assi Dios os de buenos viages, y ansi en todos los demas."
Esposo, diciendo: Ruegoos, y requieroos, hijas de Jerusalem, ansi os goceis de las ciervas, y hernosas cabras montesas, que no desperteis a mi amada, hasta que ella quiera, y hasta que ella despierte de suyo. Esta es muy comun costumbre de todos los buenos autores, $y$ aun de todas las gentes, orar la felicidad, o desgracia del estudio, y exercicio de otro, quando le quieren rogar algo, o le desean mal: como a uno, que estudia le decimos: ansi Dios os haga un gran letrado; y a uno que pretende dignidades: ansi os vea yo un gran señor; y al marinero: ansi os de Dios buenos viages; $y$ desta manera en todos los demas."

Insistimos en que los pasajes con este grado de identidad se repiten en el texto con mucha frecuencia. No se trata de llegar en este punto a una conclusión, pero lo que sí podemos hacer ya es formular una hipótesis. Es casi imposible que dos autores distintos, puestos a hacer una obra de las mismas características, coincidan no sólo en las interpretaciones sino también en los ejemplos de una forma tan clara, por lo que pensamos que los dos textos, sobre todo $\mathrm{L}$ que es el que aquí nos ocupa de una manera especial, debieron pertenecer al mismo autor, es decir, Fray Luis de León es el autor de ambos textos. 
En cuanto al sentido espiritual, ambos textos coinciden en ver en estos versículos una manifestación del amor de Dios, el cual no quiere que sus hijos sean despertados cuanto éstos están heridos, un Dios que protege al hombre cn todo momento.

8.- ;Voz de mi amado!; ;Helo! Viene atrabancando por los collados, saltando por los montes.

9.- ¡Heio! Ya está tras nuestra pared, acechando por las ventanas, mirando por las celosias.

La larga explicación que en ambos textos se ofrece de estos versículos del libro sagrado es la que, hasta el momento, más se parece en ambos textos. Desde la alusión a un conocido poeta español (Ausias), hasta el final son ambos textos idénticos.

Resulta especialmente curiosa la introducción en la que se dice que todos estos aspectos que, a continuación, se van a comentar pueden ser difíciles de entender para las personas desconocedoras del amor $y$, aunque puedan parecer niñerías, son cosas que los amantes tienen en mucha estima. Se compara al Esposo con los ciervos por la rapidez con la que se ha acercado a la Esposa. Después, cuando él ha llegado a la casa se inicia un juego de "tras" en el que el Esposo se esconde de la Esposa.

"Es el cuidado del amor tan grande, $y$ esta tanto en vela en lo que desea, que de mill pasos como dizen lo siente, entre sueños lo oye, y tras los muros lo ve. finalmente es de tal naturaleza el amor que haze obras en quien reina diversas mucho de la comun opinion de los hombres, y por esto los que no sienten tal affecto en si esperiençia no creen, o los paresçe milagro, o, por
"Es el cuidado del amor tan grande, y esta $\tan$ en vela en lo que desea, que de mil pasos, como dicen, lo siente, entre sueños lo oye, y tras los muros lo ve. Finalmente es de tal naturaleza el amor, que hace obras en quien reyna, diversas mucho de la comun experiencia de los hombres; y por esto los que no sienten tal afecto en si, no las creen, o les parecen milagros, o por mejor decir, 
mejor dezir locura ver y oyr las tales cosas en los Enamorados, y de aqui resulta que los autores ^ $q$ tratan de amor son mal entendidos y juzgados de algunos autores de deuaneos, $y$ disparates, por lo qual vn antiguo poeta Enamorado de nuestra naçion, honesto $y$ mui entendido. hizo prinçipio a sus cançiones, diziendo en su lengua lemosina semejante seña.

No uea mis scriptos quien no este triste, $o$, quien no ha estado triste en tiempo alguno., assi que las estrañas cosas que sienten, hazen y dizen los que aman no se pueden entender de los libres de amor, donde sera forçoso que muchas cosas deste libro sean escuras, ansi al compositor del, como a los demas que en el diuino amor estan frios, $y$ por el contrario sera mui claro todo al que tuuiere en si la seña desta obra y ninguna cosa le pareçera impossible, ni disparatada.- Vemos aqui que la Esposa cansada del trabajo passado esta durmiendo. y con todo en el punto que su Esposo habla, siente su voz, y la conosçe sin errarla, y se auisa de su venida diziendo. La voz de amado"

(Texto L, págs. 143-144) locura, ver, $y$ oir las tales cosas en los enamorados. $Y$ de aqui resulta, que los autores que tratan de amor son mal entendidos, $y$ juzgados por autores de devaneos, y disparates. Por lo qual, un Poeta antiguo, y bien enamorado de nuestra nacion, dixo bien en el principio de sus canciones esta sentencia:

No vea mis escritos quien no es triste, $O$ quien no ha estado triste en tiempo alguno. Ansi que las extrañas cosas que sienten, dicen, y hacen los que aman, no se pueden entender, ni creer de los libres de amor; de donde sera forzoso, que muchas cosas deste libro sean escuras, ansi al expositor del, como a los demas que en el divino amor estan frios, $y$ tibios; y por el contrario, sera muy claro todo al que tuviere, $y$ experimentare en si la sentencia desta obra, y ninguna cosa le parecera imposible, ni disparatada.

Pues vemos aqui, que la Esposa cansada del trabaxo pasado esta durmiendo, y con todo eso en el punto que su Esposo habla, siente su voz, y la conoce sin errarla, y se avisa de su venida, diciendo: Voz de mi amado."

(Texto M, págs. 61-63) 
En lo que respecta al sentido espiritual, este fragmento muestra la presteza de Dios en acudir a prestar su auxilio al hombre cuando éste se encuentra en algún apuro.

10.- Hablado ha mi amado y dijome: ;Levántate, galana mia, y vente!

11.- Ya ves, pasć el invierno, pasó la lluvia, fuese.

12.- Descubre las flores la tierra, el tiempo del cantar es venido, oida es la voz de la tórtola en nuestro campo.

13.- La higuera brota ya sus higos y las viñas de pequeñas uvas dan olor.

Todos estos versos los oye la Esposa cuando está recuperándose de su desmayo y con ellos el Esposo la invita a que salga con él al campo, ya que el invierno y sus inclemencias ya han pasado y allí ella se encontrará mejor pudiendo ambos gozar de su amor. Ésta es la explicación que ofrecen los dos textos con no pocas coincidencias.

En cuanto al sentido espiritual sólo es desarrollado por $L$ que ve en la llegada del verano la venida del Hijo de Dios, enviado por su padre para sacar a la Iglesia, su amada, de la postración en que se encuentra a causa de las acechanzas de los enemigos. Al fin, cuando Dios consiga sacar a la Iglesia de su postración, celebrarán sus "santas bodas".

14.- Paloma mia, puesta en las quiebras de la piedra, en los escondrijos del paredón, descúbreme tu vista, hazme oír ia tu voz; que la tu voz dulce y la tu vista bella.

Sigue el Esposo requebrando a la Esposa y, en este momento, le pide que se vaya con él a un lugar apartado, ya que él es palomo celoso y la quiere sólo para él. Su mayor riqueza es gozar con ella de su amor, tenerla junto a él, las demás riquezas del mundo no le importan, sólo ésta. Esta explicación de la letra es casi igual en ambos textos, aunque más pormenorizada en $\mathrm{L}$. 
"Declara ya el Esposo a la Espa la condiçion de su amor y como se ha de auer con el en este offiçio de amarlo, pues ya es tiempo ^ $q$ se junten a viuir en vno, como arriba lo mostro, y para dailo a entender trae vna bellisima semejança de las palomas cuya propiedad sabida estara claro este lugar. I hanse de tal manera las palomas en su compañia, que desque vna vez se Enamoran, dos, macho y hembra para viuir juntos, ya mas deshazen la compañia hasta que el vno falta de en medio, y esto nasçe del natural amor que se toman, y la paloma esta muy obediente a todo el querer del palomo tal que no le basta todo el amor y lealtad que de su naturaleza le tiene, sino ^q tambien sufre muchas riñas $y$ importunos çelos del marido (porque esta aue es la ^ $\mathrm{q}$ mas muestras de çelos da) y ansi en viniendo el de fuera luego hiere con el pico a su compañera, y con la voz aspera da grandes indiçios de sospecha çercandola mui azorado, y arrastrandola esta y a todo esto ella esta mui pasçiente sin se mostrar aspera $y$ estas aues entre todos los animales brutos muestran mas claro el amor que se tienen ser de gran fuerça assi por eí
"Declara pues en esto el Esposo a su amada la condicion de su amor, y como se ha de haber con el en este oficio de amarlo, y trahe para ello una gentil semejanza de las palomas, cuya propriedad sabida, quedara claro este lugar. Hanse de tal manera las palomas en su compañia, que despues que una vez se hermanan dos, macho y hembra, para vivir juntos, jamas deshacen la compañia, hasta que el uno ciellos falta; $y$ esto nace del natural amor que se toman. Y la paloma esta muy obediente a todo el querer del palomo, tanto que no le basta el amor, y la lealtad, que de naturaleza tiene, sino que tambien sufre muchas riñas, $\mathrm{y}$ importınos zelos del marido. Porque esta ave es la que mayores muestras de zelos da entre todas las demas; $y$ ansi en viniendo de fuera, luego hiere con el pico a su compañera, luego la riñe, y con la voz aspera da grandes indicios de su sospecha, cercandola muy azorado, y arrastrando la cola por el suelo; $y$ a todo esto ella esta muy paciente, sin se mostrar aspera, ni enojada. $Y$ estas aves entre todos los animales brutos, muestran mas claro el amor, que se 
andar siempre juntos, y guardarse lealtad el vnc al otro con gran simpliçidad como por los besos que se dan, y los regalos que se hazen despues de passadas aquellas yras que los çelos en el marido leuantauan. Pues de esta manera misma notifica el Esposo a su Espa en las palabras ^ $q$ ahora le dize que se han de ver ambos en el amor, y quando arriba dixo (compañera mia) ya començaua apuntar esta semejança porque quasi en todas las lenguas, la junta de las palomas se llama compañia y ellas se llaman compañeras, y suelese dezir a esta paloma le falta el compañero, pues venid aca compañera mia (dize el Espo) que ya es tiempo que juntemos esta tierna compañia. sabed $\wedge q$ yo soy palomo, y vos aueis de ser paloma, y no de otro palomo, sino mia. paloma mia, amada mia, y assi yo he de ser amado y compañero vuestro. Este amor ha de ser firme para siempre, ninguna cosa ha de bastar para deshazerlo, o, disminuirlo, $y$ con todo esso yo os tengo de pedir zelos y porque aunque ay muchas palomas en vn lugar cada qual viue por si, ni ella sabe el nido ageno, ni el palomo estraño les quita el suio. Es razon ^q nosotros nos apartemos a nuestra poyatilla aparte nos tienen, ser de gran fuerza, ansi por el andar siempre juntos, y guardarse la lealtad el uno al otro con gran simplicidad, como por los besos que se dan, y los regalos que se hacen despues de pasadas aquellas iras. Pues desta misma manera notifica el Esposo a la Esposa, que se han de haber entrambos en el amor. $Y$ ansi le dice: Ven aca, compañera mia, que ya es tiempo que juntemos este dulce desposorio: sabed que yo soy palomo, y vos habeis de ser paloma, y no de otro palomo, sino paloma mia, y amada mia, y yo amado, y compañero vuestro. Este amor ha de ser firme para siempre, sinque ninguna cosa :amas lo disminuya; y con todo esto yo os tengo de pedir zelos. Y porque aunque haya muchas palomas en un lugar, cada par vive por si, ni ella sabe el nido ageno, ni el palomo extraño le quita el suyo; es razon que nosotros tambien nos apartemos a nuestra poyatilla aparte. Por eso venios al campo, paloma mia, aqui en esta peña hay unos agujeros muy aparejados para nuestra habitacion, aqui hay unas cuevas en esta barranca alta, aqui me mostrad vos, paloma mia, vuestra vista, y aqui os oiga yo cantar, que aqui me agradais, y 
es razon $\wedge_{q}$ vos andeis entre la gente $y$ yo me este en el campo, si me quereis agradar ha de ser a solas, si aueis de cantar conmigo solo ha de ser, por esso venios conmigo al campo paloma mia, aqui en esta peña ay vnos agujeros muy aparejados para nuestra habitaçion, aqui ay vnas cuebas en esta barranca alta, aqui me mostrad vos paloma mia, vuestra vista, y aqui os oyga yo cantar $\wedge_{q}$ aqui me agradais y en esta soledad vuestra vista me es muy bella, y vuestra voz suauisima". en esta soledad vuestra vista me es muy bella, y vuestra voz suavisima."

(Texto M, págs. 69-71)

(Texto L, pág. 148-149)

El texto $\mathrm{L}$, al comentar el sentido espiritual, dice que éste está muy claro una vez dicho lo anterior; y es cierto, Dios es celoso, quiere que sólo lo amemos a Él y además que lo amemos con humildad, en la pobreza, no en la abundancia.

15.- Prendedme las raposas, las raposas pequeñas destruidoras de viñas, que la nuestra viña está en flor.

16.- El amado mío es mío y yo soy suya, (de él) que apacienta entre las azucenas.

Estamos, una vez más, ante dos exposiciones casi idénticas de unos mismos versículos. Sólo hay que hacer dos excepciones a esta identidad. En primer iugar, $\mathbf{M}$ explica que estos versículos pueden estar, indistintamente, en boca del Esposo o de la Esposa, mientras que L los pone únicamente en boca de la Esposa. En segundo lugar, M no incluye comentario espiritual, cosa que sí hace $L$. Veamos ahora el resto de la exposición. 
"llamada la Espa a la compaxia de su Esp ${ }^{\circ}, y$ teniendo entendido el amor que le tiene ponese muy ufana y regalada, $y$ viene en este lugar a ser mouida de vn affecto comun a los regalados en teniendo delante de si a quien los ama y regala. declararlo hemos en vna semejança. Quando vna madre esta ausente, o, la ha estado de vn niño su hijo, en veniendo luego pregunta por el, y lo llama y lo abraça mostrandole aquella terneza de amor que le tiene., loprimero $\wedge q$ el haze es quexarse de quien lo ha offendido en ausençia de su madre porque el deseo ^ $\urcorner$ tiene de vengarse le fuerça a que pida socorro de quien puede vengarlo. Lo mesmo haze vna Esposa, o, muger casada ^q mucho ama a su marido el qual ha tenido algun espaçio de tiempo apartado de si, luego se le regala quexandose de las desgraçias que en su ausençia le har acaesçido. Este affecto muestra aqui la Enamorada y tierna Espa y regalada con el llamar de su Esposo, y con los demas que le dixo, quexase de la cosa que mas la offende, y es como ella tenia vna viña $\wedge q$ arriba hemos visto la qual preçiaua mucho por ser suya y de su Espº y veya
"Ufana pues la Esposa, y muy regalada con los favores, y dulces palabras, que le acababa de decir su querido, viene en este lugar a ser movida de un afecto que es muy comun a los regalados, teniendo delante de si a quien los ama, y regala. Declararlo hemos por este exemplo. Quando una madre ha estado ausente de su niño, y en viniendo luegu pide por el, y lo llama, y lo atraza mostrandole aquella terneza de regalo, que le tiene; lo primero que el hace, es quejarse de quien le ha ofendido en su ausencia, y con uncs graciosos pucheritos relata, como puede, su injuria, y pide a la madre que le vengue. Lo mismo hace una esposa, o muger casada, que mucho ama a su marido, $y$ le ha tenido ausente, que luego se le regala quejandose de las desgracias, que le han sucedido en su ausencia. Este afecto muestra aqui la Esposa, luego que se vee acariciada, y regalada con el llamarla su Esposo, y con lo demas que le dixo. Quejase de la cosa que mas le ofende, y es que como eila tenia una viña, la qual precizba mucho, y veia ya que las viñas estaban en cierne, y comenzaba a quedar limpio el agraz, tiene gran temor, que las 
que las vides estauan ençierne y que daua ya a quedar limpio el agraz. Tiene gran temor que las raposas se la hechen a perder, y quexandose de la mala casta dañadora pide socorro al Esp ${ }^{\circ}$, y a los pastores sus compañeros. diziendo. Caçadnos las raposas, las raposas pequeñas. guarda bien la propiedad de naturaleza porque quando las virias estan en agraz, y comiençan a madurar. Entonçes las raposas de las camadas se crian, y estas hazen despues mucho daño a las viñas, porque son muchas $y$ van juntas, como por su poca fuerça no se atreuen a hazer salto en el gado, ni en las gallinas, ni en las otras cosas que los raposos viejos caçan, y destruyen. vanse a las viñas doncie ay menos concurso de hombres, y perros, y ellos son menos vistos fur la espesura de las hojas, y pampanos, y alli hazen mucho daño, por tanto ruega la Esp que les busquen las camadas y las tomen y maten mientras son aun pequeñas, porque sera mas façil assi de deshuyrlas, $\wedge \mathrm{q}$ no esperando a que crezcan, y declarandose dize las raposas pequeñas) quiere dezir. agora gue son pequeñas $\wedge^{q}$ es buen tiempo, agora que las viñas estan en agraz, antes que crezcan ellas y maduren las ubas. Vino a muy buen tiempo esta quexa en raposas se la echen a perder; y quejandose de la mala casta dañadora, demanda socorro al Esposo, y a los pastores, sus compañeros, diciendo: Cazadme las raposas pequeñas. $\mathrm{Y}$ en decir pequeñas, guarda bien la propriedad de la naturaleza; porque quando las viñas estan en agraz, y antes que comiencen a madurar, entonces las raposillas cie las camadas se crian, y estas hacen despues mucho daño en las viñas, porque son muchas, y van juntas; y como por su poca fuerza no se atreven a hacer salto en los ganados pequeños, ni en las gallinas, ni en las otras cosas, que los raposos viejos cazan, y destruyen, vanse a las vinas donde hay menos concurso de hombres, $y$ de perros, y ellas son menos vistas porla espesura de las hojas, y pampanos, y ansi hacen mucho daño: y por eso pide la Esposa que las prendan, y maten mientras son aun pequeñas, que sera mas facil que despues. $\mathrm{Y}$ ansi dice, las raposas, y declarandose mas añade, las raposas pequeñas. $\mathrm{Y}$ vino a muy bien tiempo este quejarse de la Esposa, porque, corno habemos dicho, en tal tiempo se suelen quejar, y pedir venganza los que tiernamente aman. $Y$ ansi son todos los iugares deste libro, 
la Espa'. porque (como hemos dicho). En tal tiempo se suelen quexar y pedir vengança contra quien les offende los que tiernamente aman $y$ sienten muestras del amor ^q se les tiene y assi son todos los otros lugares deste libro, donde pareçe no tener dependençia las vnas palabras de las otras, que si se considera y entiende el sentido lo tiene muy grande e mui trauado por^q estos libros en que se tratan passiones de amor, y dolor, yra y enojo, y otros tales, lleuan sus razonamientos, $y$ las ligaduras dellos en el affecto, no en las palabras, $y$ esto es menester aduertirse $y$ amonestarse muchas vezes,...” donde parece no tener dependencia las unas palabres de las otras, que si bien se considera el sentido del afecto, la tienen muy grande, y muy trabada. Porque estos libios donde se tratan pasiones de amor, o otras tales, llevan sus razonamientos, $\mathrm{o}$ las ligaduras dellos en el hilo de los afectos, y no en el concierto de las palabras, lo qual es menester que se advierta muchas veces."

(Texto M, págs 72-75.)

(Texto L, pág. 151-152)

17.- Hasta que sople el dia y las sombras huyan, tórnate, sei semejante, amado mío, a la cabra o al corzo sobre los montes de Betel.

La mujer teme quedarse sola de noche y por eso la Esposa pide a su Esposo que se quede con ella esa noche, que vuelva de donde está tan rápidamente que asemeje a las cabras por los montes de Betel. Así comentan ambos textos la letra, además L, en el comentario espiritual, dice que este momento se refiere a la situación de tinieblas en que vivió la Iglesia antes de la llegada de Cristo. Pide la Iglesia, por tanto, que no se la deje sola en las tribulaciones hasta la llegada del Nuevo Testamento "en el que ahora estamos". 


\section{CAPÍTULO III}

1.- En el lecho en las noches busqué al que ama mi alma; busquéle y no le hallé. Levantarme he ahora y cercaré por la ciudad, por los barrios y por los lugares anchos, buscaré al que ama mi alma; busquéle y no le hallé.

2.- Encontráronme las rondas que guardan la ciudad, (Preguntéles) ¿Visteis por ventura al que ama mi alma?

3.- A poco que me aparté de ellas, (anduve) hasta hallar al amado de mi alma, asile y no le dejaré hasta que le meia en la casa de mi madre y en la cámara de la que me parió.

Ante todas las peticiones de que venga a su casa que ha hecho la Esposa a su Esposo y como este no viene, decide salir ella a buscarle. Sale durante la noche, sin miedo a nada, y se encuentra, en primer lugar, con las guardas, las cuales no le dan ninguna pista de dónde está su amado; después de dejar a las guardas encuentra a su amado y decide no soltarlo hasta que lo tenga encerrado en su casa. Así comentan el sentido de la letra L y M.

En el sentido espiritual, que comentan los dos textos, queda claro que a Dios no se le puede encontrar en la comodidad (cama) humana; hay que salir sin miedo a buscarlo y esto es lo que hace la Iglesia, no fiándose de las guardas (dirigentes), sino buscándolo por sí sola, y una vez que lo encuentra lo pone a buen recaudo para tenerlo siempre para ella.

4.- Conjuroos, hijas de Ierusalén, por las cabras y por los ciervos del campo, si despertáredes y velar hiciéredes al amor hasta que quiera.

Una vez que la Esposa ha conseguido llevar al Esposo hasta su casa y éste está durmiendo después de haber estado andando toda la noche, la Esposa, lógicamente, pide a los demás que no despierten a su amado con las mismas palabras que él conjuró a las doncellas para que no la despertaran a ella cuando se desmayó. 
Ésta es la interpretación de la letra que hace $\mathrm{L}$ acerca de estos versículos. Por otra parte M se limita a remitir a la interpretación que hizo de estos mismos versículos puestos en boca del Esposo.

El sentido espiritual que desarrolla $L$ nos revela que Dios entra en la casa del que no lo busca, como lo tiene prometido, y alli permanece para siempre, a no ser que en aquella casa no se viva conforme a la piedad; por eso la Esposa pide que no se haga nada que lo pueda alterar.

5.- ¿Quién es ésta que sube del desierto como columnas de humo, de oloroso perfume de mirra y encienso y de todos los polvos olorosos del maestro de los olores?

La forma de interpretar estos versos del Cantar de los Cantares no es la misma en L y M. Éste explica que no hay ninguna relación con lo anteriormente dicho desde aquí hasta el final del capítulo. Parece que después de haber contado los prolegómenos a las bodas sagradas, Salomón, comienza ahora, a relatar cosas diferentes.

Por otra parte, $\mathrm{L}$ afirma que estos versos son puestos en boca de las gentes que rodean a la Esposa que, al verla tan mejorada después de sus amores con el Esposo, se preguntan quién es, porque no lo conocen. La asemejan a una fina columna de humo producido por perfumes olorosos, de los más preciados olores que por aquellos lugares tanto abundan.

Respecto al sentido espiritual, ninguno de los dos textos lo menciona; podríamos pensar que esto se debe a que el sentido espiritual de estos versos está muy claro si tenemos en cuenta la línea que sigue la exposición espiritual de ambos textos.

6.- Veis el lecho suyo, que es el de Salomón; sesenta valientes en su cerco de los más valientes de Isrcel.

7.- Todos ellos, la espada en la mano, ejercitados en guerra; la espada de cada uno sobre su muslo por el tei or de las noches.

Es normal que si se había producido una ruptura en la interpretación de los versos ésta continúe hasta el final del capitulo.

M afirma que estos versos hacen mención al gran poderío del rey Salomón y la consiguiente necesidad de personas que velen por su vida. 
L, por el contrario, dice que es aquí donde se desvela la personalidad del pastor-esposo al hablarse directamente de Salomón. Éste quiere mostrar a su Esposa el cuidado y protección que junto a él tendrá.

En el sentido espiritual sí coinciden ambos textos y comentan que estos versos son una muestra del cuidado que el anor (Dios) pone para proteger a aquellas personas que lo siguen, protegiéndolos de todas las adversidades del mundo. Resulta llamativo, al menos, el hecho de que ambos textos ofrezcan una explicación distinta de la letra del texto sagrado y coincidan en el comentario espiritual. Esto puede dar mayor solidez a la hipótesis que antes planteábamos acerca de la posierior elaboración del texto $\mathrm{L}$ respecto a $\mathrm{M}$.

\section{8.- Litera hizo Salomoir para si de los árboles del Líbano.}

9.- Las columnas de plata, el techo de oro cuibierts de puirpura, y todo él sembrado de amor por las hijas de Jerusalén.

Se prosigue la enumeración de las riquezas de Salomón y, en este caso, se habla de su aposento realizado con ricos materiales y sembrado, 0 encendido de amor por las hijas de Jerusalén. Éste es el sentido de la letra y en él coinciden ambos textos, incluso en las explicaciones más oscuras, como podría ser la aclaración de la frase “...y todo él sembrado de amor por las hijas de Jerusalén".

L

"Y assi tiene mui graçioso $y$ gentil sentido; ^ $\mathrm{q}$ despues de auer mostrado la fabrica de su tabernaculo como es muy rica en materiales, muy graçiosa en compostura, porque la plata bien labrada sustenta al oro, y las vigas que estan en el techo estan cubiertas de purpura, de manera que solas. haze de estos tres preçiosos colores, oro, plata, y purpura se

\section{M}

"Lo qual tiene muy gracioso, y gentil sentido, que despues de haber mostrado la fabrica de su trono, como es muy rica en materiales, y muy graciosa en compostura (porque la plata bien labrada sustenta al oro, y las vigas que estan en el techo estan cubiertas de purpura, de suerte que de las luces destos tres preciosos materiales, oro, plata, y purpura, se hace una bella mezcla, 
halle vna bella mezcla ^ $\mathbf{q}$ se viene a los ojos con graçiosa vista dize luego. Este tan graçioso pauelion hizo Salomon para si. En medio del qual se entro y esta alli encendido de amor, por vna de las hijas de Jerusalem que era su Esposa, la qual aun^q fuesse estrangera de naçion esta muy auezindada y hecha çiudadana de Jerusalem por auer casado El rey con ella". que se viene a los ojos con graciosa vista) dice luego, este tan hernioso trono hizo Salomon para si, en medio del qua' se entro, y esta alii encendido de amor por una de las hijas de Hierusalem, q̨ue era su Esrosa, la qual, aunque fuese extragera de nacion, estaba ya avecindada, y hecha ciudadana de Hierusalem, por haberse casado con el Rey della."

(Texto M, págs. 94-95)

(Texto L, pág. 55)

El sentido espiritual sólo es aportado por L, muy extenso, y en él se identifica cada uno de los omamentos descritos con la Iglesia y sus pilares y sostenes, siendo Dios la globalidad del edificio, que lo ha construido para albergue de su amada, "de las hijas de Jerusalén", de la Iglesia.

10.- Salid, hijas de Sión, y ved al rey Salom on la corona con que le coronó la su madre en el día de su desposorio y en el dia del regocijo de su corazón.

Con estos versículos se llega al final del capítuio y de la descripción que está haciendo la Esposa de su Esposo. En este momento, una vez descritas sus riquezas materiales, la Esposa llama a "las hijas de Sión" para que vean a su Esposo y lo beilo que sale con la corona "que le puso su madre el día de su desposorio". Éste es el sentido de la letra expuesto por nuestros textos.

El sentido espiritual, realizado sólo por L, nos muestra que en este pasaje se manifiesta la alegría de la primera comunidad cristiana cuando Cristo resucitó y se produjo el desposorio entre Él y la Iglesia. 


\section{CAPÍTULO IV}

1.- ¡Ay qué hermosa te eres, amiga mía, ay que hermosa! Tus ojos de paloma entre tus cabellos; tu cabello como un rebaño de cabras que miran del monte Galad.

A la hora de comentar estos versos del Cantar de los Cantares ambos textos están de acuerdo en que su primera parte ya está comentada anteriormente $e$ insisten, ambos, en que las comparaciones que a partir de ahora se van a hacer son difíciles de entender, porque no son muy usuales en nuestra lengua.

Los dos textos se centran en la explicación de la letra correspondiente a la segunda comparación coincidiendo en no pocas cosas. Al parecer, las cabras que apacentaban en el monte Galad dejaban entre la humedad de los árboles su pelo y, al salir de estos bosques, les relucía el pelo nuevo, mucho más hermoso. Veamos ahora la descripción que se hace del monte Galad en ambos textos.

L

"El monte Gilgaad esta assentado a la parte ocçidental del Rio Jordan y tiene este nombre desde el conçierto ^q tuuo Jacob, y Laban su suegro como se cuenta en el libro de la creaçion, y es monte de muchos arboles y frescos, como el libano, y de hermosos pastos, como lo dan a entender Amos, y Heremias, y Zacharias, $y$ entre las otras plantas ^ $q$ en el se crian ay muchos arboles y matas resmolas. Pues andando por el las cabras pasçiendo, como son animales sueltos encaramanse por los arboles y metense por las matas de

\section{M}

"Porque se ha de presuponer, que el monte Gilgaad esta asentado a la parte occidental del Jordan, y tiene este nombre desde el concierto que hubo entre Jacob, y Laban su suegro, como se cuenta en el libro de la Creacion, y es monte de muchos, y frescos arboles, como el libano, y de hermosos pastos, como lo dan a entender Hieremias, Amos, y' Zacharias. Entre las otras plantas, que en el se crian, hay muchos arboles, y plantas hermosas. Pues andando por el las cabras pasciendo, como sor. animales sueltos, encaramanse 
donde es neçessario $\uparrow q$ los pelos dellas $\wedge$ son viejos, y mas arraigados, y estos mui limpios, compuestos, y luçios, assi por andar ludiendo, y refregandose por las matas y arboles y peñas, como por'q se untan con la resina que de los arboles se derrite, la qual suele hacer luçir los pelos y cabellos, y assi el Esp ${ }^{\circ}$ dize $\uparrow q$ los cabellos de su Esposa son tan gentiles, tan luçios y tan compuestos, como suelen ser los de las cabras $\wedge_{q}$ andan por las espesuras de Ghilghad, ' $q$ alli se pelan, y peinan, y ponen muy hermosas, y esto quiere dezir la voz hebrea, $\mathfrak{q}_{\mathbf{q}}$ donde en nuestra traslaçion dezimos (se leuantan) el hebreo dize (se peinan, y pelan). De manera que por parte de ojos y cabellos ya esta bien loada de hermosa".

(Texto L, págs. 169-170) por los arboles, y metense por entre las matas, donde es necesario, que los pelos dellas, que son viejos, y estan ya poco asidos al cuerpo, se salgan, y solamente queden los nuevos, y mas arraigados, y estos muy limpios, compuestos, y lucios, por que se untan con la resina, que de los arboles se derrite, y se curan, y hermosean con ella, la qual suele hacer lucir los pelos y cabellos. $Y$ ansi el Esposo dice, que los cabellos de su Esposa son tan gentiles, tan lucios, $\mathrm{y}$ tan compuestos, como suelen ser los de las cabras, que andan por las espesuras de Gilgaad, que alli se pelan, y peynan, y parescen muy hermosos. Y esto quiere decir la voz hebrea, que donde en nuestra traslacion decimos, se levantan, en el hebreo dice, se peynan, o pelan. De manera que por parte de los ojos, y cabello queda la Esposa bien loada de hermosa."

(Texto M, págs. 105-106)

Esto es en cuanto al sentido de la letra; en cuanto al sentido espiritual, desarrollado sólo por L, asemeja los cabellos de la Ėsposa a los pensamientos, que según la descripción del Esposo están bien ordenados y asentados como es propio de la gente justa. 
2.- Tus dientes como hato de ovejas trasquiladas que salen de bañarse; todas paren de dos en dos y ninguna de ellas hay vacía.

Estamos ante uno de los más bellos pasajes de toda la Exposición... no sólo por la forma de llevar a cabo las comparaciones, sino también por el alcance de las mismas. Los dos textos coinciden exactamente en la explicación de la letra.

L

"y a las ouejas como hemos visto vienen muy juntas con su manada, de manera $\Upsilon_{\mathbf{q}}$ a quien las mira algo apartado pareçen todas vna misma cosa blanca como sabana tendida que no se vee entre ellas mas espaçio, que ay de los pies de la vna a los pies de la otra, por^q por ser delgados los pies, y los cuerpos gruesos tocanse arriba con los lados del cuerpo, y abaxo lleuan los pies vna de otra apartados, y assi va aquello negro con la sombra $\uparrow q$ ellas hazen, mas quando vna ha parido, dos, como aqui dize luego veremos los cordericos entre ellas encaxados, de manera $\uparrow q$ cada madre lieua sus, dos, hijos a los lados, y assi entre cada dos ouejas dos corderitos vienen a henchir todo aquello vaçio $\wedge_{q}$ los pies dellas descauan, y deste modo no queda entrada a la vista de quien las mira para penetrar entre ellas, ni conosçer $\wedge_{q}$ vna este apartada de otra, sino todo por abaxo, y por arriba pareçe vn cuerpo blanco, y
M

"Porque como se vee, las ovejas vienen $\tan$ juntas en su manada, que a quien las mira algo apartado, le parecen ser todas una cosa blanca, como sabana tendida, que no se paresce entre ellas mas espacio, que lo que hay de los pies de la una a los pies de la otra; poraue por ser delgados los pies, y los cuerpos gruesos, tocanse arriba con los lados del cuerpo, y abaxo llevan los pies una de otra apartados, y ansi va aquello negro con las sobras que ellas hacen. Mas quando son llenas, y han cada una parido dos, como aqui dice, vienen los corderitos encaxonados entre ellas, porque cada una lleva sus dos hijos a los lados, los quales hinchen aquel vacio, que los pies dellas dexaban; $y$ deste modo no queda entrada a la vista de quien las mira para penetrar en ellas, ni conocer que una este apartada de otra, sino todo por abaxo, y por encima parece un cuerpo blanco, y hermoso, como la experiencia lo demuestra. Pues dice el pastor en este 
hermoso, como la experiençia lo muestra, Pues dize el pastor en este lugar $\uparrow_{q}$ los dientes de su Esposa son ni mas, ni menos, porque ellos son blancos en el color como las ouejas reçien bañadas, $y$ son tan parejos y juntos vnos con otros como las mesmas ouejas quando vienen en su manada, y por'q muchas personas tienen los dientes por la parte de arriba juntos, mas por sus nasçimientos donde juntan las ençias los tienen apartados, demas ^ q pueden meter por entre diente, $y$ diente vn buen alfiler, como lo vemos en muchas bocas. Por esso dize el Esp ${ }^{\circ}$. que los dientes de su Espa estan tan juntcs por abaxo, como por arriba, tan iguales $y$ parejos como las ouejas $\uparrow q$ vienen cada qual con dos cordericos $\uparrow q$ ninguna ay vaçia entre ellas, $y$ pudieralos comparar a un sartal de perlas, 0 , a otra tal cosa preçiosa, y gentil como hazen otros Enamorados, mas con esta semejança de las ouejas guardo mejor el decoro, y conueniençia de pastor, y declaro mucho mas la hermosura $y$ igualidad dellos $\uparrow q$ con ninguna otra semejança de las otras se pudiera declarar"

(Texto L, págs. 172-173) lugar, que los dientes de su Esposa son ni mas, ni menos, porque son tan parejos, $y$ tan juntos L..os con otros, como las ovejas quando vienen en su manada. $Y$ dice, que son tan juntos en su nascimiento por abaxo donde se juntan con las encias, y donde algunas personas los suelen tener apartados, como lo estan por arriba; tan iguales, y parejos, como las ovejas, que vienen cada qual con sus dos corderitos, $y$ no hay vacia entre ellas. Pudieralos asemejar a un sartal de perlas, 0 a otra cosa preciosa, y gentil, como hacen otros enamorados; mas en esta semejanza de las ovejas guardo muy mejor la conveniencia de pastor, y declaro mas enteramente la hermosura, y igualdad dellos, que con ninguna semejanza de las otras se pudiera deciarar."

(Texto M, págs. 107-109) 
Respecto al sentido espiritual, ofrecido por $\mathrm{L}$, tenemos que decir que, hasta el momento, es uno de los mejor conseguidos por su elaboración. Por esta razón no lo expresamos aquí, sino que remitimos a texto $\mathrm{L}$, pág. 172, para su lectura completa.

\section{3.- Como un hilo carmesi tus labios y el tu hablar polido; como el casco de granada tus} sienes entre tus copetes.

Si antes el elogio se hacía de los dientes, ahora se hace de los labios, el hablar y las sienes. Los labios han de ser de color rojizo y el hablar acorde con el conjunto de tan bellos labios y dientes. Las sienes, por otro lado, tienen que presentar una mezcla de color rojizo y blanco como las granadas. De este modo se consigue un ideal de belleza muy arraigado en la cultura oriental y occidental hasta no hace mucho tiempo. Éste es comentario de la letra expresado por L y $\mathrm{M}$.

El sentido espiritual, únicamente aportado por $\mathrm{L}$, expresa que todo este conjunto de belleza llena de contento al Esposo porque es manifiesta a todos.

4.- Como la torre de David el tu cuello fundada en los collados; mil escudos cuelgan de ella, todos escudos de valientes.

\section{5.- Tus dos pechos como dos cabritos mellizos que están paciendo entre las azucenas.}

La belleza parece estar asentada sobre dos pilares fundamentales: por un lado, la buena disposición del rostro, y, por otro lado, el cuello como puente de unión entre la cabeza y el resto del cuerpo. De esta descripción del cuello trata este apartado del comentario y se compara el de la Esposa con una esbelta torre que construyó el rey David en la cumbre de un monte, la cual estaba llena de escudos de los valientes que la guardaban. En esta interpretación de la letra coinciden $\mathrm{L}$ y $\mathrm{M}$.

Parece que $\mathrm{M}$ ha abandonado por completo el sentido espiritual, cosa que no hace $\mathrm{L}$ con el sentido de la letra. En este sentido espiritual expresa $L$ que Dios se alegra de ver a su Esposa tan bella y alta, fijándose en las cosas altas y divinas. Sus pechos entiende $\mathrm{L}$ que son los dos Testamentos, Nuevo y Antiguo, que son el alimento de los creyentes. 
6.- Hasta que sople el día y huyan las sombras, voyme al monte de la mirra y al collado del incienso.

\section{7.- Toda eres hermosa, amiga mia, y en ti no hay falta.}

Una vez que el Esposo ha loado toda la belleza de su Esposa se retira a dormir "al monte de la mirra y al collado del incienso"; esto es le que interpreta M. Por otro lado, L no dice que se vaya a dormir sino que va a estos lugares a recoger estas plantas olorosas para ofrecérselas a su Esposa. Cuando vuelve resume toda la belleza de su Esposa, pormenorizada antes, con la frase "toda eres hermosa, amiga mía, y en ti no hay falta".

El sentido espiritual ofrecido por $\mathrm{L}$ dice que aquí se ve la etapa de oscuridad de los creyentes antes de la venida de Cristo. La mirra y el incienso son adelantos de esta venida, los profetas que lo anunciaban.

8.- Conmigo del Líbano, Esposa, conmigo del Libano te vendrás, otearás de la cumbre de Amana, de las vertientes de Senir y Hermón, de las moradas de los leones y de los montes de los pardos.

Rápidamente pide el Esposo a la Esposa que abandone esos montes salvajes donde se encuentra y se venga junto a él. Esta explicación de la letra es la que ofrecen L y $\mathrm{M}$.

En el sentido espiritual expresa L que hay que ver en esta llamada del Esposo la llamada de Dios a su Iglesia para que se aparte de las sectas salvajes (leones y pardos) que buscan su mal, y se reúna rápidamente con él.

9.- Robáste mi corazón, hermana mía, robaste mi corazón con uno de los tus ojos, con un sartal de tu cuello.

Narra ahora el Esposo a su Esposa las heridas que le ha producido su amor, ya que desde un primer momento, con una sola mirada de la Esposa, con un solo collar de los que la adornaban, el Esposo quedó enamorado. Éste es el sentido de la letra que apor'an ambos textos. Veamos ahora cómo lo desarrollan. 
"No se puede disimular el don por aquella persona en quien reyna luego pone su escudo en el rostro del Enamorado, luego lo haze a el mesmo pregonero de su passion todas las otras passiones, $y$ affectos del coraçon pueden hazer menos ruido y estruendo dentro en el de manera que los de fuera no sientan quien esta alla, mas este viuo fuego no puede estar ^q no humee, da estallidos buena, y deça llama, y esto ha sido causa muchas vezes de graues afanes, fatigadas y discontentos a los amadores, por`q muchas vezes vno açierta amar un colaçon rustico y avillanado, 0 , altiuo, el qual pareçe $\uparrow$ le ama antes $\uparrow$ sopa quanto es amado, mas despues $\bigwedge_{\mathrm{q}}$ el otro le descubre la gran rebuelta de sus pensamientos $\wedge_{\mathbf{q}}$ por su causa le hazen guerras viendo $\uparrow q$ la tiene subjecto, se ensoberueçe, y no le muestra el amor que primero, cosa indigna de nobles coraçones, y tanto mas a cauer con passion del ' $q$ en tal modo padeçe por auer descubierto sus entrañas, quanto menos fue en su mano dexallas de descubrir.

En este lugar venido y ei Esposo a la conuersaçion de su Fspa. le comiença tiemamente a mostrar las barias cosas de
"No se puede disimular el amor por aquella persona, en que reyna; luego le hace a el mismo pregonero de su pasion. $Y$ aunque todos los demas afectos, y pasiones del corazon se pueden encubrir, este vive fuego, por mas cuidado, y diligencia que se ponga, no se escusa que no se descubra donde $\epsilon$ sta, que no humee, de estallidos, y levante llama, que suele ser principio de grandes afanes en los amadores. Que muchas veces acierta uno a amar un corazon rustico, 0 altivo, el qual parece, que ama tambien, y se esfuerza a pasar lo que debe, antes que sepa enteramente que es amado; mas despues que el otro le descubre la gran revueita de sus pensamientos, que por su causa le hacen guerra, viendo que lo tiene sujeto, se ensoberbece, y se alza a su manc, y no le muestra el amor que primero. Cosa indigna de nobles corazones, $y$ tanto mas es de haber compasion del que en tal modo padesce por haber descubierto sus entrañas, quanto menos en su mano fue dexarlas de descubrir. Pues en este lugar viene ya el Esposo a no poder mas encubrir su pena, y comienza tiemamente a mostrar las heridas que en su corazon el crudo amor ha hecho, diciendo: $O$ Esposa 
su coraçon $\uparrow q$ su maior en el ha impremido diziendo. 0 , hermana mia, 0 Esposa mia, herido has mi coraçon, herido y despedaçado lo has con solo vn ojo tuio, y con solo vn collar de tu cuello quiere dezir con sola vna vista de vna vez ^ $\mathbf{q}$ me miraste, y de vna vez ^q yo te vy, dando a entender quan subito se apodero en el amor $\uparrow q$ apenas vna vez lo hubiste para ini tan graçioso mirar quando senti en my coraçon la herida de tu amor, y repitiendo dos vezes la razon heriste, heriste mi coraçon, muestra la vehemençia, y fortaleza de su amor y argumenta en sus palabras, como si dixese, si sola una vista tuia y vn collar de los que tu sueles ponerte quando te engalanas basta fara me rendir herido en tu amor, quanto mas seran para meter a prisa an tu poder $y$ amor todas tus vistas, tus hablas, tus risas y ti: beldad todas juntas." mia, o hermosa mia, robado has, herido has mi corazon, herido, y despedazado lo has con solo un ojo tuyo, con solo un collar de tu cuello: como si dixera, con sola una vista, de una vez que me miraste, y de una vez que yo te vi apuesta, y galana. Dando a entender, quan de subito se apodero el amor, y argumentando ocultamente en sus palabras, como si dixese: Si sola una vista thya, y un collar de los que tu te sueles poner quando te compones, basto para rendirme a tu amor; quanto mas fuertes seran para me tener preso todas tus vistas, tus hablas, tus risas, y tu beldad toda junta? "

(Texto M, págs. 118-120)

(Texto L, págs. 178-179)

En el sentido espiritual se ve a un Dios enamorado de su Esposa (Iglesia), de la cual le llaman la atención las cosas más insignificantes, como un collar y de la cual se enamora con sólo una mirada de ella.

10.- ¡Cuán lindos son tus amores, hermana mia Esposa, cuán buenos son tus amores más que el vino! El olor de tus olores sobre todas las cosas olorosas. 
11.- Panal destilan tus labios, Esposa, miel y leche está(n) en tu lengua, y el olor de tus arreos, como el olor del Líbano.

Poco hay que decir para la explicación de estos versos bíblicos, ya que son un resumen de todo lo anteriormente expuesto, manifestado, ahora, con otro tipo de comparaciones. Veamos ahora alguna de las explicaciones que ofrecen $\mathrm{L}$ y $\mathbf{M}$ para declarar estos versículos:

"Añade todavia loores a la hermosura de su Esposa como aquel $\uparrow \mathbf{q}$ tanto la ama $\wedge_{\mathbf{q}}$ no puede callar su amor, ni se harta de alabarla y assi prosigue. 0 , hermana mia querida, y dulçisima Espa . graçiosos y bellos son tus amores mas suauidad, y alegria me pone amarte que la que suele poner el vno a los que lo hazen con gran gusto. Tus tus azeites que son aigalias y los demas olores que traes donde sale tanta fragançia vençe a todos los olores del mundo, que los que, otras traen no huelen $\tan$ bien como los tuios. Tus palabras son tan dulçes ^ $\mathrm{q}$ no pareçe sino ^ $q$ tu lengua anda bañada en miel y leche, $\mathrm{y}$ tus labios derraman tanta dulçura como el panal de la miel. Tus vestiduras te estan $\tan$ bien, te adoman, y huelen tanto $\mathbf{q}$ pareçes con ellas el bello monte Libano donde ay tanta frescura, y assi en la vista de las verdes y floridas plantas, como en los suaues olores ^q alli el ayre mezcla".
"Que es como si junto con ella, y enterneciendose en su amor, dixese: $\mathbf{O}$ hermana mia dulcisima, y querida Esposa, mas alegria me pone el amarte, que es la que suele poner el vino a los que con mas gusto le beben. Tus ungüentos, y aceytes, que son las algalias, y los demas olores que trahes contigo, vencen a todos los del mundo; en ti, y por ser tuyos, tienen un particular, y aventajado olor. Tus palabras son todas miel, y tu lengua parece que anda bañada en miel, y leche; $y$ no es sino dulzura, gracia, y suavidad, todo lo que sale de tus labios. Hasta tus vestidos, demas que te estan bien, y adoman maravillosamente tu gentil persona, huelen tan bien, $y$ tanto, que paresces con ellos al bello monte libano, donde tanta frescura hay, ansi en las verdes y floridas plantas, como en los suaves olores, que el ayre mezcla".

(Texto M, págs. 121-122)

(Texto L, pág. 180) 
Respecto al sentido espiritual, L entiende que también está todo, o casi todo, comentado anteriormente, como ocurría con el comentario segin la letra.

\section{2.- Huerto cercado, hermana mía Esposa, huerto cercado, fuente sellada.}

13.- Las tus plantas cual jardin de granados, con frutas de dulzuras, juncia de olor $y$ nardo.

14.- Nardo y azafrán, canela y cinamomo, con los demás árboles aromáticos, mirra, lináloe, con todos los principales olores.

15.- Fuente de huertos, pozo de aguas vivas que nacen del monte Libano.

16.- iSus, vicela, cierzo, y ven tú, ábrego, orea este mi huerto y haz que se esparzan sus olores!

Queda claro por qué se agrupan tantos versículos para comentarlos juntos. El sentido de la letra es interpretado por los dos textos somo la descripción que hace de la Esposa el Esposo comparándola, o mejor dicho, identificándola con lo que nosotros conocemos ccmo locus amoenus.

El sentido espiritual apuntado, de nuevo, por los dos textos está muy claro; una vez pasadas todas las adversidades, Dios goza y se alegra con todas lac cosas buenas que tiene su Iglesia conseguidas gracias a la ayuda de su creador.

Veamos ahora cómo cierran ambos textos este capítulo:

"y esto esta claro y es muy conforme bendiçion a la naturaleza de huerto segun la regla $\uparrow q$ ya arriba referimos $\uparrow q$ quando bendezimos, 0 , aborreçiendo detestamos alguna persona, 0 , cosa hablamos
"Y esta bendicion es dicha ansi, y muy graciosamente, por ser conforme a la naturaleza del huerto, de quien se habla. Porque es regla, que quando bendecimos, - maldiciendo aborre-cemos alguna 
conforme a su offiçio y naturaleza como lo hizo el Elegantisimo Dauid en aquella lamentaçion $\uparrow$ hizo sobre la muerte de Saul, Diziendo, o, montes de Gelbos esteriles seays sin ningun fruto, ni plantas priuados del benefiçio del çielo, $\wedge q n i$ roçio, ni agua desçienda sobre vos otros"

(Texto L, pág. 183) persona, o cosa, la bendicion, o maldicion ha de ser conforme a la naturaleza, y su oficio de la cosa. Como lo hizo David en aquella lamentacion, que hizo sobre la muerte de Saul, y Jonatas, diciendo: 0 montes de Gelboe, esteriles seais sin ningun fruto, ni planta, privados del beneficio del cielo, que ni rocio, ni agua caiga sobre vosotros."

(Texto M, págs. 130-131) 


\section{CAPÍTULO V}

\section{1.- Venga el mi amado a su huerto y coma la fruta de sus manzanas delicadas.}

2.- Vine a mi huerto, hermana mía Esposa. Cogi mi mirra y mis olores, comi mi panal con la miel mía, bebi mi vino y la mi leche. Comed, compañeros, bebed y embriagadvos, amigos.

Como la Esposa ha sido comparada e identificada con un huerto, ésta decide llamar a su Esposo en los mismos términos y así, para pedirle que venga a ella, lo hace diciéndole que venga a su huerto. El Esposo no se hace de rogar y promete ir rápidamente, aunque utilice los verbos en pasado, ya que "propiedad es de la lengua hebrea decir en pasado lo venidero". Promete venir y gozar de la presencia de su Esposa y gozar de todos los frutos agradables que el huerto le ofrece, convidando incluso a sus compañeros, los pastores. Éste es el sentido de la letra expuesto por $\mathrm{L}$ y M.

En cuanto al sentido espiritual, ofrecido por $L$, queda claro que en esa premura del Esposo está la premura de Dios en venir a gozar de los frutos que le ofrece su Esposa, la Iglesia, que no es otra cosa que la Doctrina Sagrada que sirve de alimento a los fieles.

Al final de la exposición de estos versículos, el texto $M$ nos ofrece una aproximación a lo que va a ser todo el capítulo: la llegada del Esposo, la tardanza en abrirle, la marcha del Esposo, la búsqueda del mismo por parte de la Esposa, la descripción del Esposo por parte de la Esposa para facilitar su búsqueda a las hijas de Jerusalén que acuden en su ayuda.

3.- Yo duermo y mi corazón vela; la voz de mi querido llama: Ábreme, hermana mía, compañera mía, paloma mía, perfecta mía, porque mi cabeza está llena de rocío y mi cabello de las gotcs de la noche. 
Estamos, de nuevo, ante una interpretación de la letra idéntica en ambos textos, repitiéndose palabra por palabra de uno a otro.

Parece natural que entre los enamorados el corazón no funcione a la par con el resto del cuerpo y así puede estar el cuerpo durmiendo y el corazón en vela, pensando en la persona amada. Por eso la Esposa se despierta rápidamente al oír al Esposo que le pide que abra porque la noche está fría.

El sentido espiritual, aportado en este caso por los dos textos, se ve en esa Esposa, la Iglesia, en fase de postración por los problemas que la cercan en el mundo, pero siempre alerta a la voz de Dios que viene a ella para reconfortarla.

Veamos ahora cómo expresan ambos textos la exposición de la letra de estos versículos:

L

"Dizese del que ama ^q no viue consigo mas de la mitad y la otra mitad que es la mejor parte que viue, y esta con la cosa amada $\operatorname{por}^{\wedge} q$ como nuestra anima tenga dos offiçios vno de criar, y consenuar el cuerpo mediante las obras ^q para esto haze, comer, dormir y las demas, el otro offiçio es pensar, ymaginar, y contemplar exerçitando la prinçipal parte suia, quando vno ama nunca su alma esta en el, ni en cosa ^q a el pertenezca, contemplando, pensando, ni imaginando, sino en la cosa amada. En aquella sola se emplea, $y$, en el conosçimiento, y deseo de aquelia se ocupa solamente obra en si las obras de la vida animal, $y$ estas avn no
M

"Dicese del que ama, que no vive consigo mas de la mitad, y la otra mitad, que es la mejor parte del, vive, y esta en la cosa amada. Porque como nuestra alma tenga dos oficios, uno de criar, y conservar el cuerpo, y el otro, que es el de pensar, y imaginar exercitandose en el conocimiento, y contemplacion de las cosas, que es el primero, y mas principal; quando uno ama, este oficio, que es de pensar, $y$ imaginar, nunca lo emplea en si, sino en aquella cosa a quien ama, contemplando en ella, y tratando siempre della; solamente da a si, y a su cuerpo aquello primero, que es un poco de su presencia, y cuidado, quanto ha menester, para tenelle en 
perfectamente. Esto $\widehat{\Upsilon}$ hemos assi propuesto simplemente sin mas philosophar, en ello nos auvlara la grandeza del amor que en este lugar muestra la Espa. diziendo ( $\%$ duermo, $y$ mi coraçon vela) porque dize. $\widehat{\wedge}$ aunque duerme, no duemse del todo, ni toda ella reposa por^q su coraçon ^a no esta con ella, sino con su amado esta siempre velands con el cuidado, como quiera $\wedge q$ su coraçon se aya entregado al amor, y seruiçio de su Esp", no tiene que ver con ella, y assi no obra juntamente con ella en su prouecho por^q vno querria huyr los trabajos del amor, mas el coraçon dize yo los quiero suffrir, dize el que ama. graue carga es esta, responde sli coraçon, de llevaria tenemos, quexase el amante que pierde el tiempo, la vida, la esperança, dale el coraçon todo por bien empleado, $y$ assi quando el cuerpo duerme, y reposa, entonçes esta el coraçon velando, y negoçiando con las fantasias de amor, recibiendo, y enuiando mensajes".

(Texto L, págs. 188-189) vida, y sustentalle, y aun esio no todas veces enteramente. Esto ansi prosupuesto simplemente, y $\sin$ philosophar en elio mas, nos declara la grandeza del amor, que en este lugar muestra la Esposa diciendo: Yo duermo, $y$ mi corazon vela. Porque dice, que aunque duerme, no duerme del todo, ni toda ella reposa, porque su corazon no esta en ella, siry, con su amado esta siempre velando: que como se ha entregado al amor, y servicio de su Esposo, no tiene que ver con ella, $y$ ansi no obra juntamente con ella en su provecho. Porque el uno querria huir los trabajos del amor; mas el corazon dice, yo los quiero sufrir. Y dice el que ama, grave cosa es esta; y dice el corazon, de llevarla teriemos. Quejase el amante, que pierde el tiempo, la vida, las esperanzas; dalo el corazon todo por bien empleado. Ansi quando el cuerpo duerme, y reposa, entonces esta el corazon velando, y regocijandose con las fantasias de amor, rescibiendo y enviando mensages".

(Texto M, págs. 138-140) 
4.- Desnudéme mi vestidura; ¿cómo me las vestiré? Lavé mis pies; ¿cómo los ensuciaré?

5.- El mi amado metió la mano por entre el resquicio de las puertas, y mis entrañas se estremecieron en mí.

6.- Levantéme a abrir a mi amado y mis manos gotearon mirra y mis dedos mirra que corre, sobre los goznes de la aldaba.

Nos enconträmos ante una declaración de la letra en la que ambos textos ofrecen una explicación idéntica,

Esta identidad de los textos no llega al comentario espiritual, ya que éste es ofrecido sólo por L. Además creemos que ni el sentido literal ni el espiritual necesitan, en este caso ningún tipo de aclaración, ya que con la lectura de los versos es suficiente para su comprensión.

L

"Aqui se pinta muy al viuo vn melindre, 0 , como le llamaremos ^q acaesçe, y es mui comun a las mugeres. haziendose esquiuas donde no es menester, y muchas vezes deseando mucho vna cosa, y quando la tienen a la mano fingen no querella, $0, \wedge_{q}$ les sea enojosa., ha la Espa. deseado $\wedge^{q}$ su Esposo viniese, y dicho que sin el no puede vna hora viuir $\mathbf{y}$ rogandolo $\uparrow q$ venga, y no la dexe sola y despertada con gran alegria a la voz del que venia, $y$ agora en sintiendolo llamar ensoberueçese, $y$ rehusa de le abrir, y
$\mathbf{M}$

"En lo qual se pinta muy al vivo un melindre, o como lo llamaremos, que es comun $\delta$ las mugeres haciandose esquivas donde no es menester; y muchas veces, deseando mucho una cosa, quando la tienen a la mano, fingen enfadarse della, y que no la quieren. Ha la Esposa deseado, que su Esposo viniese, $y$ dicho que no podia vivir sin el una sola hora, y rogadole que venga, y despertado con alegria, y con presteza, a la primera voz del Esposo, y al primer golpe, que dio a la puerta; $y$ ahora, que lo vee venido, ensoberbecese, y 
hazese delicada por hazerlo penar, y ganan aquella victoria, mas del, y dize poniendo frias escusas (denudeme my camisa, como la tornare a vestir) $\wedge \mathbf{q}$ estara fria (laveme los pies poco ha para acostarme, tengolos agora de ensuçiar poniendolo en el suelo). Es gentil trueque este $\wedge \mathrm{q}$ viniendo el $\mathrm{Esp}^{\circ}$ a ella cansado, y mojado, auiendo passado el sereno, y mal trato de la noche, y ella no quiere suffrir por ella la camisa fria".

(Texto L, pág. 190) emperezase en abrirle, y hace de la delicada por hacerle penar, y ganar aquella victoria mas del. $\mathrm{Y}$ dice, poniendo frias excusas: Desnudeme mi camisa, como la vestire, que estara fria? laveme mis pies poco ha para acostarme, tengolos de ensuciar, poniendolos en el lodo? Que es gentil trueco este, que viene el Esposo cansado, y mojado, y habiendo pasado por vella el sereno, y mal rato de la noche; y ella rehusa de sufrir por el la camisa fria".

(Texto M, pág. 144)

No nos resistimos a hacer, en este punto, una reflexión en cuanto al contenido. Se trata de ver la relación y conexión existente entre el comentario de la letra y el espiritual, y cómo el primero lleva irremediablemente al segundo, que es al que realmente se quiere llegar, usándose el primero como medio. Esto lo hacemos notar por lo pueril y sin sentido que puede parecer, en la letra, la actitud de la Esposa, que ha estado rogando a su Esposo encarecidamente que venga, cuando éste llega. Pero todo esto, el sentido literal, sirve de puente para llegar a un sentido espiritual en el que se ve a unas personas deseosas de la palabra de Dios y su presencis, pero no dispuestas a abandonarlo todo cuando éste llega.

7.- Yo abri al mi amado y el mi amado se habia ido y se habia pasado. Busquéle y no le hallé, llaméle y no me respondió.

8.- Hallárorme las guardas que rondan la ciudad, hiriéronme, tomáronme mi manto que sobre mi tenia, las guardas de los muros. 
9.- Yo os conjuro, hijas de Jerusalér, que, si halláredes a mi querido... Mas, ¿qué le contaréis? Que soy enferma de amor.

10.- ¿Qué tiene el tu amado más que otro amado, oh hermosa entre la mujeres? ¿Qué tiene el tu amaa'o sobre otro amado? ¿Por qué asi nos conjuraste?

Debido a la demura de la Esposa por abrir la puerta a su Esposo, éste ya se había ido y ella avergonzada por su tardanza no se vuelve a la cama, sino que sale a la calle a buscarlo. En esta búsqueda nocturna se encuentra con las guardas de la ciudad que la maltratan y quitan el velo; pero ella no se desanima sino que reanuda su búsqueda y pide ayuda a las hijas de Jerusalén para que le ayuden a buscarlo. Éstas, lógicamente, piden a la Esposa una descripción de su amado para que, cuando lo encuentren, le puedan decir que ella muere de amor. Éste es el sentido de la letra, y una vez más, es muy parecido en $\mathrm{L}$ y $\mathrm{M}$.

Pero esto no es todo, ya que el conıentario espiritual de estos versos es exactamente igual en ambos textos, aunque no necesita ninguna explicación lo que estos versículos sugieren al espiritu.

Veamos ahora cómo inician ambos textos lá explicacién de estos versículos:

L

"A muy buen tiempo el Esposo vsa del

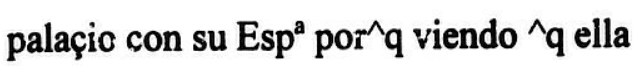
al prinçipio no le quiso abrir dandole quasi a entender ^ $q$ no le auia menester, $y \wedge q$ sin el estar podia, El prouo abrir la puerta por lugar donde ella estaua, mas como la sinctio leuantada y que le venia a abrir, quierele pagar la burla, como quien dixcse vos quereis darme a entender que podeys estar sin my., pues
"A muy buen tiempo usa el Esposo del palacio con su Esposa, porque viendo, que ella al principio no le quiso abrir, dandole quasi a entender, que no le habia menester, el probo a abrir la puerta; mas quando sintio, que se levantaba, y venia a abrirle, quierele pagar la burla. Como quien dice: Vos quereisme dar a entender que podeis estar sin mi; pues yo os hare conocer, 
yo os hare entender como yo me puedo mas suffrir sin vos, que vos $\sin$ my, y por esto se ausenta luego de ay no aborreçiendola, sino castigandola, y para mayor prueua de su amor de ella, y hazella penar vn rato, deseando, y temiendo, para $\wedge q$ mas gusto le sea despues la presençia de su Esp ${ }^{\circ}$, y escarmiento viendo quan mal le va con su ausençia, Dize pues la Espa, yo abri a my amado, y no le halle a la puerta como yo pensaua por^q el era ydo, $y$ passado de largo. Bien se entiende la tristeza con $\wedge q$ estas palabras dize la Esposa, como aquella ^q justamente se hallaua triste, y corrida de su desalido, y assii pareçen las palabras como de asombrada, y medio fuera de si con vna tan gran congoxa, y la representaçion de su dezir ^q se auia ydo, y que se auia passado. denota esto como quiera $\wedge \mathbf{q}$ vna persona afligida suele hablar, dos, $y$ tres y mas vezes vna misma cosa, y callar otras, ^ $q$ auia de dezir, y assi con grande angustia dize !uego, my anima se me salic en el hablar del"

(Texto L, pág. 192) como me puedo mas sufrir sin vos, que vos $\sin \mathrm{mi}$. $\mathrm{Y}$ ansi se ausenta, no aborreciendola, sino castigandola, y haciendola pasar un rato entre esperanzas, $y$ temores, para que despues guste mas, y para que juntamente escarmiente.

Dice pues: Yo abri a mi amado, y no le halle a la puerta, como pensaba, porque se era ya ido, y pasado de largo. Bien se entiende la tristeza con que la Esposa dice estas palabras, como aquella que juntamente se halla corrida y triste de su descuido; y ansi parecen las palabras como de asombrada, y medio fuera de si, que la repeticion de su decir, que se habia ido, y que se habia pasado, denota esto. Mi anima se me salio en el su hablar." 


\section{1.- Mi amado blanco y colorado, trae la bandera sobre los millares.}

12.- Su cabeza como oro del Tíber, sus cabellos crespos, negros como cuervo.

Comienza la Esposa la descripción que le han pedido las hijas de Jerusalén y dice que su amado es reconocible entre millares. Esto es en general; particularmente, su cabeza es como oro por la perfección y su cabellos negros como cuervo. Éste es el sentido de la letra, casi igual en $\mathrm{L}, \mathrm{y} \mathbf{M}$.

El sentido espiritual no aparece en ninguno de los dos textos, pero está suficientemente claro: es la idealización del amado (Dios) por parte de la amada (Iglesia).

Veamos cómo es descrito el Esposo por parte de la Esposa en ambos textos:

L

"Da al prinçipio la Espa señas de su Esposo generalmente diziendo $\wedge_{q}$ es blanco y colorado, despues va señalando las partes de su belleza cada vna en su lugar. Dize pues sabed hermanas hijas de Jerusalem ^q el my amado es blanco, $y$ roxo porque de lexos le conozcays con la luz destos colores, los quales son tan perfectos en el ^q entre millares trae la vandera"

(Texto L, pág. 194)
$\mathbf{M}$

"Da al principio la Esposa señas de su Esposo generalmente, diciendo, que es blanco, y colorado; y despues va señalando las partes de su belleza cada una en su lugar. Dice pues, sabed hermanas mias, que el mi amado es blanco, y roxo, porque de lejos le conozcais con la luz de estos colores, que son tan perfectos en el, que entre mil hombres se diferencia, $y$ hace raya, y se lleva la vandera."

(Texto M, pág. 153) 
13.- Sus ojos como los de las palomas junto a los arroyos de las aguas, bañadas en leche junto a la llenura.

Esta explicación es una ampliación de la que en otra parte se ha hecho acerca de las propiedades de los ojos de las palomas y más aún cuando éstos son mojados. "Bañadas en leche" alude al color blanco de estas palomas. La comparación con los ojos de las palomas es la misma en los dos textos.

Acerca del comentario espiritual no se dice nada en ninguno de los dos textos. Creemos que es igual a lo dicho para los versos anteriores, exaltación del amado por parte de la amada.

14.- Las sus mejillas como hileras de hierbas y plantas olorosas.

15.- Las sus manos de oro llenos de tarsis. El su vientre blanco, diente adornado de zafiros.

16.- Sus piernas como columnas de mármol fundadas sobre basas de oro fino. El su semblante como el del Libano.

17.- Su paladar dulzuras, y todo él deseos. Tal es mi amado y tal es mi querido, hijas de Jerusalén.

Continúa la larga descripción del amado por parte de la Esposa. Creemos que no necesita ninguna aclaración lo que clla dice. Sí diremos que todas estas comparaciones son normales y muy comunes en la lengua hebrea, por extrañas y sin sentido que puedan parecernos a nosotros.

Veamos cómo se hace la descripción de las manos del Esposo por parte de la Esposa en ambos textos:

"y por el mismo tenor, de las manos de su Espo. dize. que son vnos rollos de
"Y por la misma manera alaba las manos, diciendo: Las sus manos rollos 
oro llenos de tharsis, alabando la graçia y composiçion dellas, por ser largas, luengas, y los dedos rollisos tan lindos como si fuessen tomeados de oro, y la piedra de tharsis es vn poco como entre roxa y blanca, segun $\wedge_{q}$ vn hebreo antiguo llamado Abençerro la pinta, $y$ conforme a esto da a entender la Espa las vñas en que se rematan los dedos de las manos que son vn poco roxas, $y$ reluçientes como piedras preçiosas de tharsis, y por tanto las manos en su hechura, y con sus vñas seran como rollos de oro rematados en tharsis, que aqui solamente en dezir de las manos (rollos de oro) habla de la hechura de las manos, y graçia dellas, ^ $q$ del color ya ha dicho que son blancas, quando arriba dixo my Esposo es blanco, $y$ colorado".

(Texto L, pág. 197) de oro, llenos de tharsis. En lo qual alaba la gracia, y composicion dellas, por ser luengas, y los dedos rollizos, tan lindos, como si fueran torneados de oro. La piedra tharsis, que se llama ansi de la provincia adonde se halla, es un poco como entre roxa, y blanca, segun la pinta un hebreo antiguo llamado Abenezra. Y conforme a esto da a entender la Esposa las uñas, en que se rematan los dedos de las manos, que son un poco roxas, y relucientes, como piedras preciosas de tharsis. $Y$ por tanto las manos en su hechura, $y$ con sus uñas, seran cumo rollos de oro rematadas en tharsis: que aqui en decir las manos ser rollos de oro, solamente habla de la hechura, y gracia dellas; que del color ya ha dicho, que son blancas, quando dixo arriba, mi Esposo es blanco, y colorado."

(Texto M, pág. 161)

Una vez más nada se dice del sentido espiritual, aunque, en verdad, creemos que hay poco que decir.

Terminada ya esta descripción del Esposo, la Esposa lo aglutina todo en la frase "tal es mi amado y tal es mi querido, hijas de Jerusalén".

18.- ¿A dónde fue tu amado, oh bellisima entre las mujeres? ¿Hacia dónde se volvió tu amado y buscarlo hemos contigo? 
Es muy curioso el comentario a estos versos que ofrecen los dos textos. M lo único que dice es que se trata de una pregunta que se responderá en el capítulo siguiente. Por su parte, el texto $\mathrm{L}$, ro hace ningún comentario a la letra y dedica un extenso comentario al sentido espiritual, explicando todos los versos no comentados anteriormente, ya que como hemos ido apuntando, el texto $\mathrm{L}$ había abandonado también el comentario espiritual en algunos versos anteriores.

Lo cierto es que se trata de una pregunta de enlace entre este capítulo y el siguiente, que es en el que se responde a esta pregunta formulada por las hijas de Jerusalén, maravilladas por la belleza del Ėsposo hasta tal punto que prometen a la Esposa ayudarle a buscarlo. 


\section{CAPÍTULO VI}

1.- El mi amado descendió al su huerto, a las eras de los aromates, a apacentar entre los huertos y coger las flores.

2.- Yo a mi amado y mi amado a mi, que pace entre las azucenas.

Después de haber descrito la Esposa a su amado sigue buscándolo y se acuerda de que es muy posible que esté en su huerto apacentando. Baja hasta el huerto y al ver alli su rebaño comienza a gritar llamándolo para que éste venga donde está ella. Éste es el sentido de la letra y así lo entienden L y M.

El sentido espiritual, sólo aportado por $\mathrm{L}$, afirma que aunque parezca que Dios abanciona a su Esposa cuando ésta puede pasar sin él, en ei momento en que ella acude de nuevo a Él, no se lo piensa ni un momento y la recibe con los brazos abiertos, loándola como ahora veremos.

3.- Hermosa eres, amiga mía, como Tirsa, bella como Jerusalén, terrible como los escuadrones, sus banderas tendidas.

\section{4.- Vuelve los ojos tuyos que me hacen fuerza.}

Ahora, tras su regreso, los elogios del Esposo hacia su Esposa van mucho más aitos, y la compara ahora con dos ciudades, las dos ciudades más importantes que hay en aquella tierra. El gentil semblante de la Esposa lleva al Esposo a calificarlo de terrible, como unos escuadrones a punto de iniciar el combate. Una vez que ha loado la generalidad, comienza una descripción más pormenorizada. Lo primero que aparece en esta relación de la belleza de la Esposa son los ojos, ya que lo arrastran a ella. Veamos, ahora, la comparación de la Esposa con las dos ciudades, la cual hacía el Esposo al inicic de este capítulo, las ciudades son Tirsa y Jerusalén. 
"En salça grande mete los grandes amores de su Esposa, porque en los capitulos de arriba para loar la variedad de su gentileza y hermosura. La apodo a vn gentil huerto, agora lo haze semejante a, dos, çiudades las mas hermosas $\uparrow q$ auia en toda aquella tierra, la vna se llama Thyrsa ^q era çiudad de Palestina assentada en vn monte en la qual estaua la corte de los Reyes de Isrrael antes que se poblara Samaria adonde despues se mudo, y la otra es Jerusalem ^ $q$ era la prinçipal çiudad y la mas hermosa ^ $q$ auia en toda Palestina, $y$ aun en todo oriente segun tenemos notiçia por las escripturas hebreas, $y$ gentiles, y Dauid hizo un psalmo loando a la letra la grandeza, beldad, $y$ fortaleza de Jerusalem, pues destas, dos, dize el Esp $^{\circ}$ que es semejante su Espa. en hermosura, diziendo, Tan grande marauilla es verte quan bella eres en todo, y por todo, quan grande lo es ver estas dos çiudades reales en la quales las fortalezas de sus sitios. la magnifiçençia de sus edifiçios y la grandeza, y hermosura de sus riquezas, la variedad de sus artes y offiçios ponen grande admiraçion a quien las vee".
"Sube en este lugar hasta el cielo los loores de la Esposa, y vencese a si mismo loandola. Porque en los capitulos pasados para loar la variedad de su gentileza, y hermosura, la apodo a un gentil huerto; y agora la hace semejante a dos ciudades, las mas hermosas que hay en aquella tierra, Thirsa, y Hierusalem. Thirsa es nombre de una ciudad de Israel noble, y populosa, donde los Reyes tenian su asiento, antes que se edificase Samaria; y el mismo nombre muestra la hermosura de la ciudad, y su gentil, y apacible sitio: porque Thirsa quiere decir tanto, como suavidad, y contento. $\mathrm{Y}$ deciase ansi la ciudad, por el contento, y descanso que daba a los que la moraban, por ser su asiento, $y$ habitacion della descansado, $y$ apacible. Hierusalem era la principal ciudad, y la mas hermosa, que habia en toda Palestina, y aun en todo el oriente, segun sabemos por las escrituras hebreas, $\mathrm{y}$ de los gentiles, tanto que David hizo un Psalmo loando a la letra la grandeza, la beldad, y fortaleza de Hierusalem. Pues a estas dos ciudades, dice el Esposo, que es semejante el parecer bello, y hermoso, lleno de 
magestad, y de grandeza, de la Esposa, diciendo: Tan grande maravilla es verte, quan bella eres en todo, y por todo, quanto lo es ver estas dos ciudades reales, en las quales la fortaleza de sus sitios, la magnificencia de sus edificios, y la grandeza, y hermosura de sus riquezas, la variedad de sus artes, y oficios pone grande espanto, y admiracion a quien lo vee".

(Texto M, págs. 170-172)

El sentido espiritual, aportado por $\mathrm{L}$, muestra a un Dios que, tras haber conseguido recuperar a su alma amada, se regocija mucho más de su belleza y virtudes. Loa además de la belleza las propiedades que su amada tiene para liberarse de aquellos enemigos que la acechan y quieren apartarla de Él.

5.- Tu cabello como las manadas de cabras que se parecen en Galad; tus dientes como atajo de ovejas que suben del lavadero, las cuales todas paren de dos en dos y no hay estéril entre ellas.

\section{6.- Tus sienes como un casco de granada entre tus copetes.}

7.- Sesenta son las reinas y ochenta las concubinas, y las doncellas sin cuente.

8.- Una es la mi paloma, la mi perfecta, única es a su madre, ella escogida es a la que la parió. Viéronla las hijas y llamáronla bienaventurada, y las reinas y las concubinas la loaron. 
Los textos L y M a la hora de comentar los dos primeros versículos (5 y 6) del texto sagrado remiten a los lugares de otros capítulos en que estos aspectos han sido comentados, tanto para el sentido de la letra como para el sentido espiritual.

Por lo que respecta a los otros dos versículos ( 7 y 8), sí son explicados por extenso y de modo exhaustivo haciendo comprensibles aspectos como los distintos nombres que recibían las mujeres de Salomón según su origen, todo ello enfocado a que veamos con gran claridad la diferencia tajante que el Esposo establece entre todas las demás mujeres y su paloma, envidiada por todas las demás, orgullo de su madre. Veamos cómo comentan ambos textos los distintos nombres que se les dan a las mujeres:

"las concubinas entre los hebreos, no eran mançebas como algunos lo entienden, sino mugeres legitimas $\wedge_{\mathbf{q}}$ auian sido esclauas, 0 , criadas, $y$ tomalas su amo por mugeres, mas no se çeletran las bodas, por instrumento escripto, ni con las çeremonias legitirnas que en casamento de las otras libres se usauan, y estas se añadian a las mugeres prinçipales, los hijos que destas, no suçedian en los mayorasgos ni herençias capitales, mas podia bien el padre dotarlos de grandes dones para sustentamiento de sus vidas, como de todo esto ay claro testimonio en el Genesis, de Çethyra, y Agar, mugeres de Abrahan, y assi, la escriptura sagrada
"Y no se ha de entender que eran mancebas, como algunos piensan, y se engañan; antes acerca de los hebreos, las tales eran mugeres legitimas, pero mugeres desta manera, que habian sido esclavas, o criadas, y su amo las tomaba por mugeres: mas no se celebraban las bodas por instrumento escrito, ni con las ceremonias legitimas que se usaban en el casamiento de las otras, que eran libres. Y estas se añadian a las mugeres principales, y los hijos, que de estas nacian, no subcedian en los mayorazgos, $y$ herencias capitales, pero podia bien el padre hacelles algunas mandas, o donaciones para su sustentacion: como consta en el Genesis de Cetura, y Agar, mugeres de 
mas vezes llama nombres de mugeres legitimas y otras concubinas".

(Texto L, págs. 209-210)
Abraham, que la sagrada Escrituro llama ansi concubinas".

(Texto M, pág. 179)

En el comentario espiritual que hace $\mathrm{L}$ se nos presentan todas esas mujeres de Salomón como las "mayores Iglesias" con quien está casado el Esposo. Las concubinas son las Iglesias menores. Las doncellas son "todas las particulares ánimas creyentes". Pero todas esas comunidades $s \_n$ una, "la mi paloma". La madre de la Esposa es la predicación.

9.- ¿Quién es ésta que se descubre arriba como el alba, hermosa como la luna, escogida como el sol, terrible como los escuadrones?

Creemos que en la exposición de estos versos del libro sagrado lo más interesante es el comentario de la letra que hacen ambos textos, ya que en él se hace una explicación pormenorizada de la figura literaria que nosotros conocemos como gradatio y que en amibos textos se denomina encarecimiento acrecentado. La Esposa ha suscitado una gran envidia entre las mujeres, y éstas la loan mucho comenzarido a compararla con el alba, pasando por la luna, hasta llegar al sol, máxima lumbrera.

Respecto al sentido espiritual, que en este caso L liama alegórico, se ve en estas mujeres a las "fieles ánimas, que movidas por la admiración, alaban la gran belleza de la Esposa", distinguiéndola entre las demás religiones. Es, por tanto, $y$ así lo explica $\mathrm{L}$, una exaltación de las virtudes de la Esposa Iglesia Católica frente a las otras religiones.

10.- Al huerto del nogal descendí por ver los frutos de los valles y ver si está en cierne la vid y ver si florecen los granados.

11.- No sé, la mi alma me puso como los cairos de Aminadab.

12.- Torna, torna, Solimitana, torna, torna y yerte hemos. 


\section{3.- ¿Qué miráis en la Solimitana, como coros de escuadrones?}

La explicación de la letra de estos últimos versos del capítulo resulta algo distinta en los dos textos, no tanto en la traslación de las palabras hebreas al castellano, que es idéntica, como en lo que afecta a la trama general de la historia.

El texto $\mathrm{M}$ ofrece dos posibilidades: que estas palabras estén dichas por la Esposa pudiendo expresar dos cosas distintas. En primer lugar, la Esposa no quiere dar importancia a la ausencia del Esposo y le hace creer que ella ha bajado al huerto a ver si florecíar las plantas. La segunda interpretación es que con estas palabras la Esposa informa al Esposo de que el agotamiento fisico que sufre es porque bajó aprisa a ver si el huerto florecía.

La segunda opción que ofrece $M$ es creer que estas palabras las dice el Esposo, ya que como la Esposa no le abrió la puerta, él se bajó al huerto.

Por otra parte. L ofrece una sola interpretación y es que la Esposa se dio cuenta de la estancia del Esposo en el huerto porque lo vio florecido. En todos los demás aspectos del comentario de la letra sí coinciden ambos textos.

En cuanto al sentido espiritual, llevado a cabo por $\mathrm{L}$, se ven en el huerto de los nogales las Divinas Escrituras en las que la Esposa ha vuelto a encontrar a su Esposo. 


\section{CAPÍTULO VII}

1.- ¡Cuán lindos son tus pasos en el tu calzado, hija ciel principe! Los cercos de tus muslos como ajorcas, obra de mano de oficiai.

Comienzan ambos textos haciendo una introducción acerca de lo que nos vamos a encontrar en este capítulo. Cuando la Esposa arrancó a correr, en el capítulo anterior, hacia su huerto, las mujeres de Jerusalén le pidieron que no corriera y que se volviera para que ellas pudieran admirar su belleza.

En el sentido de la letra los dos textos están de acuerdo en que es una manera muy bella de empezar a describir desde los pies y continuar hacia arriba hasta llegar a la cabeza.

Curiosamente, el sentido espiritual sólo es incluido ahora por $M$, que ve en la expresión "hija del príncipe" la expresión "hijos de Dios" y el ser hijos de tal padre no se debe a nuestro amor sino a la "sola franqueza y liberalidad de Dios".

2.- Es tu ombligo como vaso de luna que no está vacio; tu vientre ün montón de trigo cercado de violetas.

3.- Los dos pechos tuyos como dos cabritos mellizos de una cabra.

4.- El tu cuello como torre de marfil; tus ojos como estanques de Hesebón junto a ia puerto de Bat-Rabim; tu nariz como la torre del Libanc, que mira frontero de Damasco

Todas las comparaciones y descripciones de la Esposa que se llevan a cabo en estos versos han sido hechas antes; ambos textos vuelven a explicarlas con los mismos términos para el sertido literal y espiritual. Nosotros nos vamos a centrar eri la descripción que los dos textos hacen de las piemas y de la nariz de la Esposa. Acerca de las piernas dicen los textos: 
"Quierc dezir sobre estas dos hermosas, y rezias columnas de hus piernas se asienta el bello edifiçio de tu persona, la primera parte es el ombligo y vientre tuio el qual esta mui hermosamente proporcionado, porque no pareçe sino vna taça tan redonda como la luna, $y^{\wedge} q$ esta taça siempre esta llena de mixtura $\wedge_{\mathbf{q}}$ es vino mezclado con agua para beber, assi ni mas, ni menos es el vientre. de virtud ^a nunca le falta, y para mas declarar esta loa del vientre torna a dezir. Es tu vientre tan redondo y litino, $\tan$ hermoso en su blancura, como vn monte de trigo cubierto de violetas blancas, y lirios, $\mathrm{y}$ es muy gentil apodo este, por`q el monton de trigo esta por todas partes ygual en reciondez $\wedge q$ en ninguna parte del ay seno, o, hoyo alguno, por^q luego los granos lo hinchen, y assi dize ser de toda parte lleno, y leuantado el vientre de la bella Esposa"

(Texto L, pág. 217)
"Pues quiere decir: Sobre estas dos hermosas colunas de tus piemas, se asienta el edificio de tu persona: la primera parte del es el ombligo, y vientre tuyo, el qual esta muy hermosamente proporcionado, porque no parece sino una taza tan redonda como la luna; y que esta taza esta siempre llena de mixtura, que es vino aguado para beber: ansi ni mas ni menos es el tu vientre redondo, bien hecho, ni flojo, ni flaco, sino lleno de virtud, que nunca le falta. Y para mas deciarar esta loa del vientre, torna a decir: $T u$ vientre, como monton de trigo, redondeado de violetas. $\mathrm{Y}$ es muy gentil apodo este, porque el monton de trigo esta por todas partes igual en redondez, que en ninguna parte del hay seno, ni hoyo alguno, porque luego los granos le hinchen; $y$ ansi dice ser de todas partes lleno, y levantado el vientre de la Esposa".

Veamos ahora lo que los textos dicen acerca de la nariz de la Esposa: 
"Tu nariz es semejante a la torre del libano ^ $q$ mira hazia Damasco, la çual torre estaua puesta en aquel monte tan nombrado, y çelebrado por su frescura, y erä muy fuerte porque seruia de atalaya en la frontera de Damasco que era cabeça de Siria assi esta tu nariz hermosa, y bien hecha que se leuanta fuera del bellisimo rostro. como aquella hermosa y fuerte torre esta assentada sobre el fresco monîe libano, y se leuanta ssbre el."
"La tu nariz es semejante a la torre del libano, que mira hacia Damasco. La qual torre estaba puesta en aquel monte tan nombrado, y celebrado por sus frescuras; y era muy fuerte, porque servia de atalaya a las fronteras de Damasco, que era cabeza de Syria. Ansi dice: Esta tu nariz hermosa, y bien hecha, que se levanta fuera de tu graciosisimo rostro, es como aquella hermosa, y fuerte torre, que esta asentada sobre al fresco monte libano, y se levanta sobre el".

(Texto L, pág. 218)

(Texto M, págs. 201-202)

5.- Tu cabeza sobre tí como el Carmelo, y la madeja de tu cabeza como la púrpura. El rey atado en las regueras.

\section{6.- ¡Cúánto te alindaste, cuánto te enmelaste, amada, en los deleites!}

La última patte del cuerpo de la Esposa que se loa es la cabeza, por ser la parte más alta del cuerpo y se la compara, nada menos, que con el monte Carmelo, el más alto de aquella tierra. En segundo lugar se habla del color de sus cabellos que eran castaños, uno de los colores preferidos en estas tierras. Por último, se le dice a la Esposa que el rey está prendado y prendido de la belleza de esos cabellos. Éste es el sentido de la letra según ambos textos. Veamos ahora la descripción que se hace en los textos del monte Carmelo y la explicación de los distintos colores del cabello y cuáles son los preferidos en la tierra de nuestra pareja de enamorados. 
"La vitima parte de las personas es la cabeça, considerando dende los pies, y llamamos en este lugar cabeça, al casco della, donde nasçen los cabellos, no toda ella con el rostro, porque el rostro, ya esta dicho y por esso dize la letra, la $t u$ cabeça $\wedge^{q}$ esta sobre $t i$, quiere dezir lo vltimo de tu cabeça ^q esta sobre todo cuerpo, que no ay arriba della mas de los cabellos, esto es tan hermoso, $\tan$ gentil, como el monte Carmelo, ^q es vn monte muy alto en tierra de Isrrael bien çelebrado en la sagrada escriptura, y para denotar quan gentil muger sea esta Esposa, le dizen que su cabeça sobrepuja a las otras, como la cumbre del monte carmelo, a los otros montes".

\section{(Texto L, pág. 220)}

"La ultima parte de la Esposa es la cabeza, considerandola desde los pies: y llamamos aqui la cabeza, el casco della, de donde nacen los cabellos, y por eso la letra dice: La tu cabeza, que esta sobre ti. Que es decir, lo ultimo de tu cabeza es $\tan$ hermoso, y tan gentil, como el monte Carmelo: que es un monte muy alto en la tierra de Israel, bien celebrado en la Escritura, por haber estado en el muchas veces Elias, y Eliseo, Prophetas. Y para denotar, quan gentil muger, y dispuesta es esta Esposa, le dicen, que su cabeza sobrepuja a las otras, como la cumbre del monte Carmelo a los otros montes".

(Texto M, pág. 202)

Veamos ahora la descripción de los distintos colores del cabello que hay en las tieiras que habitan los esposos de nuestros textos y cuál de todos esos colores es el más preciado.

L

“despues loan la belleza de los cabellos, diziendo que son semejantes a la purpura antigua de la qual agora no
"Pues siguiendo esta letra, para mejor entendimiento de la comparacion, es de advertir, que la purpura antigua, de la 
tenemos notiçia por vso, $\wedge_{q}$ era finamerte vermeja y reluzia desde lexos, como el carmin ^q los pintores dan sobre oro, 0 , plata, asemejan el cabello de la Esposa a la purpura por`q deuia de ser castaño, $\wedge \mathbf{q}$ aun^q no sea perfectamente roxo tira mas a ello $\uparrow q$ a otro color, $y$ por^q en las tierras calientes, como son las de Asia no se estima el cabello rubio, antes a los hombres esta muy bien el negro, y a las mugeres, negro, o, castaño, y otros. Que se le pareçen quando reluzen que son sus luzes roxas, assi como las luzes de lo amarillo tiran a lo blanco, y las de verde a negro.

Dizen le aqui que son sus cabellos roxos vn poco, y reluçientes como la purpura, y que son crespon y hondeados como canales, 0 , regueras de agua que van dando bueltas, y vsan luego de vn parlar comun de los Enamorados. äiziendo. En essas bueltas de tus cabellos tienes tu atado al Rey, Esp ${ }^{\circ}$ y Enamorado tuio, de los cabellos haze amor la cuerda con ^q lo liga., Es muy regalada, graçiosa, y amorosa esta loa".

(Texto L, págs. 220-221) qual no tenemos ahora noticia por uso, tenia dos cosas: que era finamente bermeja, y relucia desde lejos, como el carmesi, que los pintores ponen sobre oro, o plata. Conforme a esto, asemejan aquellas dueñas el cabello de ia Esposa a la purpura, porque debian ser castaños los cabellos, que aunque no sea perfecto roxo, tira mas a ello, que a otro color; $y$ porque en las tierras calientes, como son las de Asia, no se estima el cabello rubio, antes a los hombres les esta muy bien el negro, y a las mugeres negro, 0 castaño, o alheñado, como ellas lo suelen curar, y hoy dia lo usan las moriscas. Por eso los alaban aqui de aquel color, y mas del resplandor, que daban de si; y en esto eran muy semejantes a la purpura. Porque vemos, que el color castaño, y otros que se le parecen, son luces roxas, ansi como las luces del amarillo tiran a blanco, y las del verde a negro. Pues dicenle aqui a la Esposa, que sus cabellos soll relucientes, y un poco roxos, como la purpura, y que son crespos, y ondeados, como canales, o regueras donde el agua va dando vueltas. $Y$ usan luego parlar comun de los enamorados, diciendole: En esas vueltas de tus cabellos tienes tu atado al Rey, y Esposo, y enamorado 
tuyo; destos cabellos hace el amor la cuerda con que lo liga: que es una muy regalada, y amorosa loa".

(Texto M, págs. 206-208)

Por lo que respecta al sentido del espíritu de estos versículos, $L$ expresa que en todas las partes del cuerpo loado de la Esposa se ven los buenos juicios y propósitos que ésta posee.

7.- Esta tu disposición semejante es a la de la paloma, y tus pechos a los racimos de la vid. Dije: yo subiré a la palma y asiré sus racimos y serán tus pechos como los racimos de la vid, y el aliento de tu boca como el olor de las manzanas.

Se produce, al llegar estos versos, la máxima loa de las mujeres de Jerusalén a la Esposa. Una vez descrita toda la semblanza de la misma, ahora se habla de la planta, la estatura. Parece esta Esposa una erguida palmera que crece recta y le cuelgan los racimos, sus pechos; y el sabor y olor de su boca recuerda a las manzanas. Éste es el sentido de la letra en el que están de acuerdo ambos textos, con afirmaciones algo arriesgadas para la época, tratándose de un texto sagrado y con un abusivo uso del verbo gozar cuyas connotaciones en el siglo XVI son muy concretas.

Respecto al sentido espiritual, no aparece en ningún texto, pero creemos entender este sentido con unas connotaciones muy cercanas al misticismo y pleno disfrute de la presencia de Dios.

8.- El tu paladar como vino bueno, que va a mi amigo a las derechas, hace hablar con labios durmientes.

Continúan estas infatigables mujeres sus alabanzas $\mathrm{y}$, ahora, comparan el paladar de la Esposa con un buen vino que "se bebe a las derechas", es decir, es agradable al paladar y muestra su efecto haciendo hablar con labios durmientes, desacertadamente, como los que están medio dormidos. Éste es el sentido de la letra comentado por L y M. 
Si nos detenemos ante el comentario espiritual, nos dice $L$ que en esta loa las mujeres manifiestan su deseo de estar abrazadas con esta Esposa "que es la Iglesia en unión de fe y caridad y gozar del fruto de los dos pechos", es decir, los dos Testamentos, el Antiguo y el Nuevo.

\section{9.- Y a mi amado y el su ciesco a mí.}

Nos sorprende bastante lo que ocurre al comentar, según la letra, estos versos del libro bíblico, ya que el texto que suele ser más parco en las exposiciones, $\mathrm{M}$, se decide a resolver el probleina del comentario en muy pocas líneas, como también hace $\mathrm{L}$, para después añadir una larguísima disertación acerca de los tres tipos de amor que pueden presentarse. Un primer tipo en el que los enamorados se engañan mutuamente diciéndose que se aman sin amarse. El segundo tipo es en el que una persona ama a otra pero no es correspondido. Por fin, el tercer tipo es el amor en el que los dos amantes gozan de plena felicidad porque los dos se aman.

No queremos hacer valoraciones de esta disertación, que por otro lado está cargada de literatura; pero creemos que éste no es su lugar por no ser necesaria, en ningún momento, para la aclaración de estos versos, y así también parece que lo entiende $L$, que hace un breve comentario a los mismos.

En el comentario espiritual, que únicamente aporta L, queda claro que la EsposaIglesia se alegra mucho de que loen su belleza, pero ella es consciente de que esa belleza le viene de Dios y es para Dios.

10.- Ven, amado mio, salgamos al campo, moremos en las granjas.

11.- Levantémonos de mañana a las viñas, veamos si florece la viä, si se descubre la menuda uva, si brotaron los granados. Alli te daré mis amores.

12. Las mandragoras si dan olor, que todos los dulces frutos, asi los nuevos como los viejos, amado mio, los guardé en mis puertas para tí.

Una vez que la Esposa cuenta a su Esposo lo que las mujeres dijeron de ella le invita a que se aparten del mundo y se vayan a su huerto donde, alejados de todos, 
cuidarán su jardín, gozarán de su amor y se reconfortarán con los frutos que ha producido dicho huerto. Éste es el sentido de la letra que exponen ambos textos, aunque $\mathrm{M}$ lo hace de forma muy breve. Veamos cómo es comentado el sentido de la letra de estos versículos por los dos textos:

L

$\mathbf{M}$

"Despues destos exerçiçios no nos faltaran buenos, y dulçes mantenimientos para sustentaçion de nuestra vida porque de las puertas adentro, $\sin$ yr a comprar cosa tendremos las mas bellas frutas que el campo suele produzir. asi de las frescas guindas çerezas, çiruclas, mançanas, $y$ todas las desta suerte, como tambien de las anejas ^ $q$ pueden conseruar; que son vino, toçino, trigo, açeite con todas las otras cosas de que suele abundar la vida rustica y esto sola yo sere la que te lo

(Texto M, pág. 221)

"ardare, y adereçare".

(Texto L, pág. 225)

"Y demas destos gustos y pasatiempos, que tendremos en gozar del campo, y andarnos viendo como florescen los arboles; no nos faltaran buenos mantenimientos, dulces, y sabrosas frutas, ansi de las frescas, y recien cogidas, como de las de guarda, que son riquezas de que suele abundar la vida rustica; lo qual todo, dice, yo te lo guardare dentro de mi casa, y de mis puertas, y te lo aderezare".

El sentido espiritual, expuesto por L, muestra el interés de la Esposa por estar cerca de su Dios y alejada de las cosas mundanas que la apartan de Él. 


\section{CAPÍTULO VIII.}

1.- ¿Quién te me dará cumo heimano mío, que manases los peshos de mi madre? Hallarteia fuera, besarteia y también no me despreciarian.

2.- Meteriate en casa de mi madre, enseñariasme, hariate beber del vino adobado y del mosto de las granadas nuestras.

Comienza este último capítulo con la exposición de la letra de estos versos. La Esposa quiere que el Esposo fuese un hermano pequeño, para que los excesos de cariño que le muestra no fuesen tema de comentario entre los vecinos. Ésta es la explicación de la letra que ofrecen L y M.

Pero lo más importante de estos versos es el extenso comentario espiritual que ofrecen ambos textos y al que remitimos, ya que aquí sería muy dificil de resumir con todos sus matices. (Texto L, págs. 230-232 / Texto M, págs. 226-230).

Mostramos ahora ei sentido de la letra expuesto por ambos textos para ver el grado de identidad existente entre los mismos.

"Vna de las cosas que en el verdadero amor ay es el creçimiento suyo $\wedge_{q}$ mientras mas del se goza, mas se desea, y mas se preçia, al contrario es el amor falso, y vil, ^q es fastidioso, y pone vna aborreçible hartura, hemos visto muy bien los proçesos deste gentil amor $\wedge q$ aqui se trata como al prinçipio la Espa caresçiendo de su Esposo, deseaua
"Una de las cosas que hay en el verdadero amor es el crescimiento suyo, que mientras mas del se goza, mas se desea, y mas se precia; al contrario es el amor falso, y vil, que es fastidioso, y pone una aborrecible hartura. Hemos visto bien los procesos deste gentil amor, que aqui se trata: como al principio la Esposa, careciendo de su 
siquiera algunos besos del, despues de auer alcançado la presençia, habla, y regalos, y los abraços suios, desea tenello en el campo consigo, y ya que en el campo le tenia a sus solas gozando del donde no vuiesse quien los impidiese, querria tener mas liçençia de nunca se apartar del sino en el campo; y en el pueblo, siempre andar junta a el; y gozar de sus besos en todo lugar, y en todo tiempo, como aquella $\uparrow$ auia gustado la suauidad de los besos de su Esposo, y no querria dexar siempre de gozallos, y para mostrar este deseo la Esposa, y la manera como querria cumplillo, comiença su pregunta diziendo.

I Quien te me dara.- Esto es en lengua hebrea, oraçion de animos deseosos, y vale tanto, como oxala, o plugiese a Dios, $\mathbf{y}$ assi es aquello $\uparrow \mathbf{q}$ dize Iheremias, quien dara agua a mi cabeça? y Dauid dize. Quien me dara alas como paloma y bolare, dize pues la Espa $^{a}$ que estando a sus solas sin conuersaçion de otra gente; ella goza de los besos de su Esp ${ }^{\circ}$ y se huelga; y alegra mucho con el, mas quando esta delante gente tiene verguença, como la suelen tener las mugeres de besar a sus Esposos, y que le es gran perdida
Esposo, deseaba siquiera algunos besos de su boca; despues de haber alcanzado la presencia, habla, y regalos suyos, deseo tenerle en el campo consigo; y ya que le tenia en el campo, gozando del a sus solas $\sin$ que nadie lo estorbase, desea ahora tener mas licencia de nunca se apartar del: sino en el campo, y en el poblado andar siempre a su lado, y gozar de sus besos en todo lugar, $y$ en todo tiempo. Y para monstrar este deseo la Esposa, y la manera como queria cumplirlo, comienza, como en forma de pregunta, diciendo: Quien te dara, como hermano mio etc. La qual forma de preguntar en la lengua hebrea, es oracion de animos deseosos, y vale tanto, como, ojala, plugiese a Dios. Y ansi es aquello que dice Hieremias: Quien dara agua a mi cabeza? Y David dice: Quien me dara alas, como paloma, $y$ volare?

Dice pues la Esposa, que estando a sus solas, y sin conversacion de otras gentes, ella goza de los besos de su Esposo, y se huelga, y alegra mucho con el; mas quando esta delante de gente, tiene vergüenza, como la suelen tener las mugeres: $y$ dice, que le es gran perdida aquella, porque siempre querria estar colgada de los hombros de su 
aquella, porque siempre querria estar colgada de sus besos, sin desasirse vn punto, que pluguiese a Dios ella pudiese tenello, y tratar son el como con vn niño pequeño hermano suyo hijo de su madre ^ $q$ aun mamase, ^ $q$ como elld lo hallase en la calle arremeteria con el, y le daria mill besos delante de quantos alli estuuiesen, porque esto es mui vsado de las mugeres con los niños, y no son notadas desto, y no tienen empacho de hacer estos regalos, y mostrarles este amor publicamente. Esta façilidad desea la Espa tener en los besos de su Esp, y en gozar del, y durando aun en la semejança que ha puesto del niño. prosigue con su deseo, diziendo; En teniendole yo en casa con mill besos y abraços le daria a beber dulçe vino adobado con miel, $y$ espeçies, $y$ otras cosas que los antiguos vsauan para $\wedge q$ fuese mas suaue, y menos dañoso, y este era mas genero de regalo, $\wedge \mathbf{q}$ de ordinaria bebida, y darte ya tambien arrope de granadas, porque con todas estas cosas dulçes se huelgan los niños, y sus madres, y hermanas tienen gran cuidado de los regalar assi, y lo que dize (enseñariasme) quiere dezir (Estando tu todavia en la figura de niño) diriasme mill cosas de las ^q ouieses visto, $\mathbf{y}$
Esposo, cogiendo sus dulces besos, sin desasirse un punto: y que pluguiese a Dios ella pudiese tenerlo, $y$ tratar con el, como con un niño pequeño, hermano suyo, hijo de su madre, que aun mamase; que como ella lo hallase en la calle, arremeteria con el, y le daria mil besos delante de todos quantos alli estuviesen. Porque esto es usado mucho de ias mugeres con los niños, y no son notadas por esto, ni tienen empacho de hacerles estos regalos, ni de mostrarles este amor publicamente. Esta facilidad desea la Esposa tener en los besos de su Esposo, y gozar del. Y durando aun en la semejanza, que ha puesto del niño, prosigue con su deseo, diciendo:

2. Meteriate en casa de mi madre, enseñariasme, hariate beber del vino adobado, y del mosto de las granadas nuestras.

Quiere decir: En teniendote yo en casa, con mil besos, $y$ abrazos te daria a beber dulce vino, vino adobado con miel, y especias, y otras cosas, que los antiguos usaban para que fuese mas suave, y menos dañoso; y esto era mas genero de regalo, que de ordinaria bebida. Dariate tambien arrope de granadas: porque con todas estas cosas 
oydo por la calle, y mill cantarzicos, $\operatorname{por}^{\wedge} q$ los niños todo quanto veen, $y$ oyen todo lo parlan bien, o mal como ellos açiertan $y$ desto reçiben gran regoçijo los que los crian y aman.”.

(Texto L, págs. 229-230) dulces, se huelgan los niños, y sus madres, y hermanas tienen gran cuidado de los regalar ansi. Y lo que dice, enseñariasme, es como si dixese (estando todavia en la figura del niño) diriasme mil cosas de las que hubieses visto, y oido por la calle, y mil cantarcicos: porque los niños todo quanto veen, $y$ oyen, todo lo parlan bien, o mal, como aciertan; y desto reciben gran regocijo las madres, que los aman".

(Texto M, págs. 224-226)

\section{3.- Su izquierda debajo de mi cabeza y su diestra me abrazará.}

Antes se desmayó la Esposa por la ausencia del Esposo, ahora se desmaya porque, aunque lo tiene presente, no puede gozar plenamente de él; pero el remedio que pide para ambos desmayos es el mismo: que el Esposo ponga su mano izquierda bajo su cabeza y con la derecha la abrace. Éste es el sentido de la letra que ofrecen los dos textos. Por el contrario del seltido espiritual no se dice nada ni en L, ni en $M$.

\section{4.- Conjüroos, hijas de Jerusalén, ¿por qué despertaréis y por qué alborotaréis a la} amada hasta que quiera?

Ambos textos coinciden al comentar la 'etra en decir que la pregunta "¿por qué?" "vale tanto como rogar vedando". Así se comenta el sentido de la letra de estos versos, ya que el resto ha sido comentado antes.

El sentido espiritual, apcrtado por $\mathrm{L}$, dice que expresa que aquí se muestra el cuidado que pone Dios en que no se moleste a su Iglesia, en los momentos en que ésta se encuentra en períodos críticos, de desmayo. 
Veames ahora cómo se explica el valor de la pregunta “¿por qué?”, que aparece en estos versículos.

L

"La pregunta (porque, $\operatorname{por}^{\wedge} q$ ) vale tanto come rogar vedando, y lo mismo quiere dezir (porque despertareys, porque alborotareys) $\wedge \mathbf{q}$ sei dixera, no aiboroteys, no despertyes., y tal como esto es lo que dize el propheta $\operatorname{por}^{\wedge} q$ te apartaste señor tan lexos? porque escondes tus façes, $\wedge q$ es dezir señor no te alexes, no te ausentes. saluo $\wedge_{q}$ diziendolo por pregunta pone mas compassion, como si dixera no aveys lastima de despertarla, dexadla dormir, y passar su desmayo hasta que torne de suio a entrar en si".

(Texto L, pág. 233)
M

"La pregunta, porque, vale tanto, como rogar vedando; y lo mismo quiere decir, porque despertareis, porque alborotareis, que si dixera, no desperteis, no alboroteis. $\mathrm{Y}$ tal como esto es lo del Psalmo: Porque te apartaste, Señor, tan lejos, porque abscondes tus faces? Que es decir, Señor, no te alejes, no te ausentes; salvo, que diciendo por la pregunta, pone gran compasion, como si dixera: No habeis lastima de despertalla? Dexalla dormir, y pasar su desmayo, hasta que torne de suyo a volver en s:".

5.- ¿Quién es esta que sube del desierto recostada en su amado? Debajo del manzano te desperté; alli te parió la tu madre, alli estuvo de parto la que te parió.

Coinciden los dos textos en la exposición de la letra al decir que el primer verso está puesto en boca de las gentes que ven a la Esposa liberada ya del miedo, que la llevaba a no amar plenamente a su Esposo, y que ahora sube abrazada a él. 

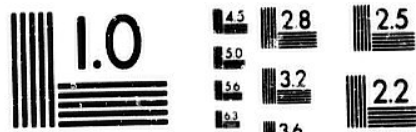

850

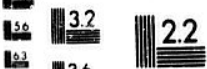

1203.6

a. 4.0

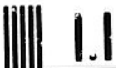

14.

4

ㄴ.

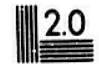

ULL
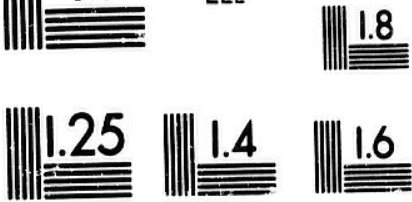

MICROCOPY RESOLUTION TEST CHART NATIONAL BUREAU OF STANDARDS STANCARD REFERENCE MATERIAL 1010a (ANSI and ISO TEST CHART NO. 2) 
Veamos anora cómo se explica el valor de la pregunta “¿por qué?”, que aparece en estos versículos.

"La pregunta (porque, $\left.\operatorname{por}^{\wedge} q\right)$ vale tanto como rogar vedando, y lo mismo quiere dezir (porque despertareys, porque alborotareys) $\wedge q$ sei dixera, no alboroteys, no despertyes., y tal como esto es lo que dize el propheta $\operatorname{por}^{\wedge} q$ te apartaste señor tan lexos? porque escondes tus façes, $\wedge q$ es dezir señor no te alexes, no te ausentes. saluo $\wedge_{q}$ diziendolo por pregunta pone mas compassion, como si dixera no aveys lastima de despertarla, dexadla dormir, y passar su desmayo hasta que torne de suio a entrar en si”.
"La pregunta, porque, vale tanto: como rogar vedando; $y$ lo mismo quiere decir, porque despertareis, porque alborotareis, que si dixera, no desperteis, no alboroteis. Y tal como esto es lo del Psalmo: Porque te apartaste, Señor, tan lejos, porque abscondes tus faces? Que es decir, Señor, no te alejes, no te ausentes; salvo, que diciendo por la pregunta, pone gran compasion, como si dixera: No habeis lastima de despertalla? Dexalla dormir, y pasar su desmayo, hasta que torne de suyo a volver en si".

(Texto L, pág. 233)

(Texto M, pág. 231)

5.- ¿Quién es esta que sube del desierto recostada en su amado? Debajo del manzano te desperté; alli te parió la tu madre, alli estuvo de parto la que te parió.

Coinciden los dos textos en la exposición de la letra al decir que el primer verso está puesto en boca de las gentes que ven a la Esposa liberada ya del miedo, que la llevaba a no amar plenamente a su Esposo, y que ahora sube abrazada a él. 
Respecto a los versos siguientes dicen ambos textos que es muy normal en los enamorados decir las cosas sin orden, y ahora la Esposa narra el inicio de sus amores con su Esposo.

Veamos cómo expresan los dos textcs el comentario de la letra de estos versos:

L

"El primer verso es parentesis, o, sentençia encaxada entre las hablas de los dos Esposos, y son palabras de las personas $\wedge q$ veyan como los dos amantes se van juntos desde el campo a la çiudad, la Esp ${ }^{a}$ venia muy pegada, y abraçada a su $\mathrm{Esp}^{\circ}$, porque despues que ella desmayo, y torno en si, se sige subir a la çiudad, y ella con mas atreuimiento ^q antes, se yua mui junta, y abraçada a su Esp', sin tener el respecto que primero tenia porque el amor le daua alientos para vençer todo esto, y parte fue para ello aquel desmayo, y esto es cosa muy aguda en este caso de amor y punto mui de notar, cada vez que alguno sobre algun negoçio le daua passion deseandolo, 0 , de otra manera, se desmaya, o, pierde el Juizio, quando torna en si tiene nueuo animo, y atreuimiento en aquel negoçio y esto es muy prouado en los que han estado sin seso, quc despues tornan otros hombres differentes de los de antes, y vemos $\wedge q$
M

"Este verso es parentesis, o sentencia entretegida en las hablas de los dos, Esposo y Esposa, y son palabras de las personas, que vian como los dos amantes se iban juntos desde el campo a la ciudad, y la Esposa venia muy junta, y pegada a su Esposo. Porque despues que ella torno en si del desmayo sobredicho, se fingen subir a la ciudad, y eila con mas atrevimiento que antes, se iba muy junta, y abrazada con su Esposo, sin tener el respeto de temor, y vergüenza, que tenia primero, y como señora ya de aquella libertad, que poco antes deseaba y pedia, como habemos visto. Porque el amor suyo, que habia llegado ya a lo sumo, le daba alientos para vencer todc esto; y parte fue para ello aquel desmayo que tuvo. $Y$ esto es cosa muy aguda en caso de amor, y punto muy de notar, que cada vez que alguno sobre algun negocio que le daba pasion, deseandolo, o de otra manera, se desmaya, o pierde el juicio; quando 
el que enloqueçio por algun caso de honrra, despues que torna en su libre poder, no estima aquello $\mathbf{y}$ destas ay cada dia muchas experiençias".

(Texto L, págs. 233-234) torna en si, tiene nuevo animo, y atrevimiento en aquel negocio. $Y$ esto es muy probado en los que han estado sin seso, que despues tornan otros hombres diferentes de los que antes; y vemos, que el que enloquece por algun caso de honra, despues que torna en su libre poder, no estima aquello; y destas hay cada dia muchas experiencias".

(Texto M, págs. 232-233)

Veamos ahora la explicación que ofrecen los dos textos a la palabra desierto:

L

"Diximos ${ }^{\wedge} \mathbf{q}$ desierto en este lugar a la letra significa lo mesmo que campo, porque assi muestra que ellos no tornauan a la çiudad sino del campo donde auia huertas, $y$ viñas con arboles, y granjas tarnbien porque este vocablo desierto. no siempre significa entre los hebreos lugares, yermos, y que careçen de habitaçion, y de pastos y verduras, antes muchas vezes significa lugares anchos, y llanos en el campo donde aun^$q$ no aya tan espesas moradas de gente, no faltal a lo menos algunas, y juntamente ay pastos, y abreuaderos
M

"Aqui desierto significa tanto como campo a la letra, porque ansi se vee, que ellos no tornaban del desierto a la ciudad, sino del campo, donde habia huertas, $\mathrm{y}$ viñas, con arboledas, $\mathrm{y}$ granjas. Y tambien, porque no siempre este nombre desierto significa entre los hebreos, lugares yermos, y que carecen de habitacion, $\mathrm{y}$ de pastos, $\mathrm{y}$ verduras; antes muchas veces significa, lugares anchos, y llanos en el campo, adonde aunque no hay tan espesas moradas de gentes, a lo menos no faltan algunas, y juntamente hay pastos, y abrevaderos. 
porque en la sagrada escriptura muchos pueblos y çiudades se cuentan estar assentada en el desierto $\wedge q$ quiere dezir vy campo llano, y assi leemos $\wedge_{\mathbf{q}}$ Moysen lleuo el ganado de su suegro al desierto mas adentro $\wedge q$ antes estaria; $y$ en Josue, a los del tribu de Juda, les cupieron, seys çiudades del desierto".

(Texto L, pág. 235)
Porque en la sagrada Escritura muchas ciudades se cuentan estar asentadas en desierto, que quiere decir, en campo llano; y ansi leemos en Josue, que a los del tribu de Juda les cupieron seis ciudades del desierto; y de Moysen se dice en el Exôdo, que llevo el ganado de su suegro, que apascentaba, al desierto, mas adentro de lo que antes estaba".

(Texto M, págs. 234-235)

Fn cuanto al sentido espiritual, que presenta sólo L, nos limitamos a dar referencia porque es muy interesante leerlo en su contexto y, adernás, sería muy dificil resumirlo aquí. Sí diremos que es la primera vez que se alude a la Virgen María en el texto. (Texto L, págs. 236-237).

Veamos ahora cómo se hace el comentario de la letra el segundo verso del libro sagrado.

L

"El sentido a la letra destas palabras pareçe ser^ $\mathrm{q}$ la Esp ${ }^{a}$ auiendo tornado en si del passado desmayo, y con mayor atreuimiento començando a gozar de su Esposo (el qual en la mayor parte desta cançion se pinta rustico pastor conforme a la imaginaçion ^ $\mathrm{q}$ el autor della tomo). Vinendo agora con el muy junta $y$ abraçada, acuerdase del prinçipio de sus
M

"El sentido destas palabras, a la letra, parece ser, que la Esposa habiendo tornado en si del pasado desmayo, y con mayor atrevimiento habiendo empezado a gozar de su Esposo (el qual en la mayor parte desta cancion se pinta rustico pastor, conforme a la imaginacion que el Autor della tomo) viniendo agora muy junta con el, y 
amores, de los quales ella agora tan dulçemente goza, y acordandose cuentalo con grande alegria, $\operatorname{por}^{\wedge} q$ vna de las condiçiones del amor Es que a los Enamorados haze de gran memoria, y en vn punto se acuerda de todas quantas cosas le han passado su prinçipio hasta el fin ante nunca jamas se les oluida cosa por pequeña, y liuiana que sea, y siempre les pareçe tener delante vn retablo de toda la historia de sus amores, acordandose del tiempo, del lugar, y del punto de cada cosa, y assi en sus dichos y escriptos, vsan muchas vezes de las cosas passadas para sus dichos y escriptos, vsan muchas vezes de las cosas passadas para su proposito. vnas vezes contandolas sin pareçer que ay para $\wedge \mathrm{q}$, y otras que se vee claro el fin de su intençion, y como la rectorica de los Enamorados consiste mas en lo que hablan dentro de si, que en lo ^ q por la lengua publican muchas vezes traen lo primero a la postre, y lo ultimo al prinçipio, como vemos en este lugar que la Esposa diçe el principio de sus amores. tanto al fin de la cançion que pareçe ^ $q$ lo deuia auer contado antes si dello querria hazer mençion (como hemos dicho) en ellos nc ay antes ny despues en estas cosas ^ $q$ todo !o tienen abrazada, acuerdase del principio de sus amores, de los quales agora goza tan dulcemente; y acordandose, cuentaselo con alegria grande. Porque una de las condiciones del amor es, que a los enamorados hace de gran memoria, que sin olvidarse jamas de cosa, por pequeña que sea, siempre les parece tener delante un retablo de toda la historia de sus amores, acordandose del tiempo, del lugar, y del punto de cada cosa. $Y$ ansi en sus dichos, y escritos usan muchas veces de las cosas pasadas para su proposito; unas veces, contandolas, sin parecer que hay para que; y otras, que se les vee claro el fin de su intencion. Y como la rhetorica de los enamorados consiste mas en lo que hablan dentro de si, que en lo que por la lengua publican, muchas veces trahen lo primero a la postre, y lo ultimo al principio. Como vemos en este lugar, que la Esposa dice el principio de sus amores tan al fin de la cancion, que parece que lo debia haber contado antes, si dello queria hacer mencion. Mas como hemos dicho, en ellos no hay antes, ni despues en estas cosas, que todo lo tienen presente en su fantasia: $y$ agora embebida en la suaviciad del amor, que delante tenia, pensando unas 
presente en su fantasia $y$ agora embebida en la suauidad del amor que delante tenia pensando unas cosas y callandolas dice otras y es lo $\wedge_{q}$ diçe esto, o, amado mio, Esposo que pareçe que ahora te ueo, la primera vez que te moui a amarme y a que tratases este desposorio comigo, y esto era estando debaxo de un arbol en las huertas, $y$ en aquellas huertas. Debaxo de aquel arbol te pario tu madre y alli estuuo de pario la que te pario (repite la sentençia como suele) Quiere deçir no eres estrangero $\operatorname{por}^{\wedge} \mathbf{q}$ de alli eras natural $y$ te auia parido tu madre, $y$ ally te desperte $y$ te moui a amarme y porque deste amor me ha hecho tan dichosa gozando del bien que por aquel gozo bendigo aquel dia y aquella hora, y aquel lugar donde tu me amaste". cosas, y callandolas, dice otras. $Y$ es 10 que decia esto: $\mathrm{O}$ amado mio Esposo, que me parece que agora te veo la primera vez, que te movi a amarme, y a que tratases este desposorio conmigo; $y$ esto era estando tu, y yo debaxo de un arbol en las huertas, y en aquella huerta, debaxo del arbol, que te pario tu madre. $Y$ alli estuvo de parto la que te pario. Repite la misma sentencia, como suele, y quiere decir: No eres extrangero, porque de alli eras natural, y alli te habia parido tu madre, $y$ alli te desperte, $y$ encendi en mi amor; $y$ porque este amor me ha hecho tan dichosa, gozando del bien, que por el gozo, bendigo aquel dia, aquella hora, $y$ aquel lugar adonde tu me amaste".

(Texto M, págs. 235-238)

(Texto L, págs. 235-236)

6.- Ponme como sello en tu corazón, como sello sobre tu brazo, porque el amor es fuerte como la muerte, duros como el infierno los celos, las sus brasas son brasas del fuego de Dios.

7.- Muchas aguas no pueden matar el amor, ni los rios lo pueden anegar. Si diere el hombre todos los haberes de su casa por el amor, despreciando los despreciará. 
Cuando ya se han superado los altibajos en la demostración del amor de la Esposa hacia el Esposo, éste le demuestra cuán verdadero y fuerte es su amor hacia ella. Le pide que lo estampe en su corazón y en su brazo con su sello. Además le pide que sea sólo para él, ya que los celos son peores que la muerte. Para encarecer mucho más su amor dice que (el amor) es un fuego cuyas llamas no pueden ser apagadas ni por un río. Éste es el sentido de la letra y así lo presentan, por extenso, ambos textos.

Por lo que respecta al sentido espiritual, L apunta que se puede entender exactamente igual que el sentido literal y estamos de acuerdo con el texto.

Siguiendo nuestra línea argumentativa, una vez más, tenemos que presentar la exposición de estos versos por parte de los dos textos, para ver la identidad que existe entre ambos textos.

"El gran misterio de este lugar es muy digno de considerar que hasta aqui el Esposo bien ha mostrado el amor que a su Espa tenga mas no del todo auiertamente que vnas uezes la regalaua, antes ^ $q$ entrasemos y otras la loaua $y$ algunas se le mostraua esquiuo fuese ayrado por^q ella poco a poco conoçiendo la falta $\wedge q$ sin el tenia aora despues que ella ha uenido a amallo con gran uehemençia y despues ^ $q$ el le ha comunicado los grandes thesoros de su graçia y dandole tan grandes dones muestrale y dale a entender quanto la ama, como si dixera entre si, ahora es tiempo. de auisar a esta my Espa. de my amor $y$ de amonestarle ^ $q$ no pierda el
"Es muy digno de considerar el misterio grande deste lugar: que hasta aqui ha mostrado el Esposo a la Esposa el amor, que le tiene, mas no del todo abiertamente, que unas veces la regalaba antes de ahora, y otras la loaba, y algunas se le mostraba esquivo, y airado, porque ella fuera poco a poco conosciendo la falta, que sin el tenia; ahora despues que ella ha venido a amarle perfectamente del todo, y que el siente ser ansi, muestrale, y dale a entender por claras palabras, sin fingimiento, ni rodeo, lo mucho que le ama. Como si entre si dixera: Ahora es tiempo de avisar a esta mi Esposa de mi amor, y amonestalla, no pierda, ni 
amor $\wedge_{q}$ me tiene $y$ diçele estas palabras, las quales pronunçia con grande $y$ uehemente affecto en esta sentençia, o Esp $^{a}$ charisima a my ten cuenta con quanto te amo y con quanto he penado por tus amores $y$ nunca me dexes de tu coraçon, nunca çeses de amarme de manera $\wedge q$ tu coraçon tenga esculpida e impresa en si mi imagen y no la de otro ninguno, haz que yo este $\tan$ simple y $\tan$ firme en tu coraçon como esta la figura en el sello, por^q la fig $^{\mathrm{a}}$. del sello no es mas de una siempre, ny se muda, hasta $\wedge_{q}$ se destruye el mysmo sello y todo quanto imprimen con el saie de vna misma imagen. Asi quiero yo $\wedge q$ tu me tengas en tu coraçon como sello $\wedge \mathrm{q}$ no este en el otra imagen sino la mia que no impriman los pensamientos en tu coraçon otro, sino a my y primero lo hagan pedaços que ie puedan hazer mudar el retrato ^ $q$ en si tiene mio y no solo deso que me tengas en tu coraçon $y$ en tus pensamientos mas tambien defuera $\wedge \mathrm{q}$ no mires a otra cosa sino a tu $\mathrm{Esp}^{\circ}$. y que todo te parezca ^q soy yo y ^q ally estoy yo y no quieras gozar, oyr, ny ver, cosa sin my, y esto haras trayendome anse tus ojos siempre como los $\wedge q$ usan a sellar sus decretos y sus escripturas, que por^$q$ disminuya el amor, que me tiene. $Y$ dicele estas palabras, las quales pronuncia con grande $y$ vehemente afecto en esta sentencia: O Esposa mia carisima, ten cuenta con quanto te amo, y quanto he penado por tus amores, y nunca me dexes de tu corazon, nunca ceses de amarme, de manera que tu corazon tenga esculpida, y impresa en si mi imagen, y no la de otro ninguno. Haz que en el este yo tan firme, como esta la figura en el sello, que esta siempre en el sin mudarse, $y$ todo quanto se imprime con el, sale de una misma imagen; ansi quiero yo que en tu corazon no haya otra imagen mas de la mia, ni que tus pensamientos impriman en el mas de a mi, y primero le hagan pedazos, que le puedan hacer mudar el retrato, que en si tiene mio. Y no solo deseo que me traigas en tu corazon, y pensamientos, mas tambien de fuera quiero que no mires, ni oigas otra cosa sino a mi tu Esposo, y que todo te parezca que soy yo, y que alli estoy yo; y esto hacello has trahiendome delante de tus ojos siempre. Como los que usan a sellar sus secretos, y sus escrituras, porque nadie las hurte, o falsee el sello, lo trahen siempre consigo en alguna sortija en la mano, de manera que siempre veen su 
nadie los pueda hurtar, ny faltar el sello lo traen siempre consigo en alguna ajorça del braço o en alguna sortixa de la mano de manera $\wedge q$ siempre vean su sello y nadie se lo pueda hurtar por` $q$ la parte de nuestra persona ^ $q$ mas presto $y$ mas a menudo uemos es las manos, $y$ sabe Esposa ^q tengo raçon de pedirte esto $\operatorname{por}^{\wedge} q$ lo que he hecho por ty por causa del amor tuyo ^q esta dentro en my el qual es tan fuerte y me ha forçado tanto sin podelle resistir $\wedge q$ ! ? muerte contra quien no uale defensa humana no es mas fuerte $\wedge q$ el amor $\wedge q$ yo tengo a ty, ha hecho este amor de my todo lo que ha querido como la muerte haze su uoluntad con los hombres sin ser ellos parte para se defender della. Deseo tambien $\operatorname{Esp}^{\mathrm{a}} \wedge \mathrm{q}$ me ames solo sin amar a otro assy $\operatorname{por}^{\wedge} q$ my amor lo mereçe como por el tormento que reçiben con los zelos los ^q aman como yo ^q te çertifiquo $\wedge q$ no les es menos dura $y$ graue la imaginacion Zelosa que la uista de la sepultura, y más facilmente sưriran que les digan en este sepulchro que esta abierto te han de hechar agora luego que sy les dixen, la que tu amas tiene otro amado, por esso ten cuenta de amarme solo, assy como solo lo merezco como por el encendido anior sello; porque la parte nuestra, que mas presto, y mas a menudo vemos son las manos. Y sabe, Esposa, que tengo razon de pedirte esto, por lo que hecho por ti, $y$ por causa del amor tuyo que esta en mi pecho: el qual es tan fuerte, y me ha forzado tanto, sin podelle resistir, que la muerte (contra quien no vale defensa humana) no es mas fuerte que el amor que el amor que yo te tengo. Ansi hecho ha este amor de mi todo lo que ha querido, como la muerte hace su voluntad con los hombres, sin ser ellos parte para poderse defender della. Deseo tambien, Esposa, que me ames solo, sin amar a otro; ansi porque mi amor lo merece, como por el tormento que reciben con los celos los que aman, como yo; que te certifico, que no les es menos grave, y penosa la imaginacion zelosa, que lâ vista de la sepultura; y mas facilmente sufriran, que les digan, en este sepulcro que aqui esta abierto, te han de enterrar ahora luego, que si les dixesen, la que tu amas tiene otro amado. Por esto ten cuenta de amarme solo, ansi como yo lo merezco, por el encendido amor que te tengo.

$\mathrm{Y}$ tornando el Esposo a contar su amor debaxo desta figura de fuego, y encendimiento, dice: Las brasas deste 
^q te tengo y tornando el Esposo a ablar $y$ recordar su amor debaxo desta figura de fuego y ençendimiento diçe las brasas dese fuego amoroso ${ }^{\wedge} \mathrm{q}$ arde en el coraçon son brasas de llama de Dios quiere deçir son brasas de biuisima y fuerte llama major y mas ardiente fuego es este $\uparrow q$ el que aca se usa por $\wedge q$ el fuego de aca con hechalle vn poca de agua se mata, mas el fuego de amor uenze a todas las aguas hechandole agua arde mas. y se embraueçe y no solamente muchos cantaros $\wedge q$ encima se baçiasen no bastan apagallos mas aun^q sobre ei se derramasen todos los enteros Rios de manera $\wedge q$ cubriesen este fuego no bastarian, con todo eso que todo lo bençe assy que tan fuerte es el amor que no basta todo el poder de la tierra para lo uençer por fuerça ny tampoco se quiere dexar vençer por dadiuas y sobornos por^$^{\wedge} q$ no se abate a nada desso el amor por su magestad antes afirmo $\wedge_{q}$ sy el hombre se quisiesse rescatar del amor quando el captuia a vno y le disse $\wedge q$ todas quantas riquezas, $y$ aberes en su casa tiene, $a^{\wedge} \wedge q$ fuesse muy rico no se curaria el amor dellas, y despreçiaria al que se las ofreçia con gran despreçio y le haria seruir por fuerça de manera $\wedge q$ el amor fuego amoroso, que arden en $\mathrm{mi}$ corazon, son urasas de llamas de Dios; quiere decir, son llamas de vivisima, $y^{\prime}$ fuerte llama. Mayor, y mas ardiente fuego es este, que el que aca se usa, porque el fuego de aca, con echarle un poco de agua, se mata; mas el fuego del amor vence a todas las aguas; echandole agua, arde mas, y se embravece, aunque se derramasen sobre el los rios enteros. Ansi que tan fuerte es el amor, que no basta todo el poder de la tierra para lo poder vencer por fuerza. Ni tampoco se dexa vencer por dadivas, y sobornos, porque no se abate a nada de eso el amor por su gran magestad; antes, dice, afirmo, que si el hombre se quisiese rescatar del amor, quando el captiva a uno, y le diese por su rescate todas quantas riquezas, y haberes en su casa tiene, aunque fuese muy rico, no se curaria el amor dellas, y despreciaria al que se las ofrecia, y le haria servir por fuerza. De manera que el amor es un señor muy fuerte, $y$ implacable, quando ha tomado posesion en el corazon de alguno. Pues siendo tal $\mathrm{mi}$ amor contigo, justo es, que tu me respondas amandome con igual firmeza".

(Texto M, págs. 239-244) 
es sefior muy fuerte e impacable $` q$ el ha tomado posession en el corazon de alguno, pues siendo tal mi amor contigo justo es que tu me respondas amandome con gran uchementia y firmeza".

(Texto L, págs. 238-240)

Veamos, por último, la explicación que se da al término infierno dentro del comentario a estos mismos versos del Cantar de los Cantares. Además veremos la explicación a la expresión "llama de Dios".

"En la letra del uocablo (infierno) declaramos sepulchro porque assy lo significa aqui y en otros muchos lugares como en aquel de Jacob, descendere al infierno, "e quiere deçir esta desgraçia de la muerte de mi hijo Joseps. me ha de acabar, y lleuar a la sepultura donde diçe tambien (llamada de Dios) declaramos rezia y fuerte llama porque en la escriptura untan el nombre de Dios a las cosas que quieren exagerar y encareçer como montes de Dios, cedros de dios quiere decir altissimos, crecedissimos çedros y assy dice Dauid al señor tu justiçia es como ios montes de Dios y de semejante deçir usamos los
"For el vocablo, infierno, entendemos, sepulcro. Asi se entiende aquello de Jacob: Descendere al infierno. Esta desgracia de la muerte de mi hijo Joseph me ha de acabar, y llevar a la sepultura. Donde dice, llama de Dios, declaramos recia, y fuerte llama; porque la sagrada Escritura junta el nombre de Dios con las otras cosas, que quiere encarescer, y exâgerar; como montes de Dios, cedros de Dios, quiere decir, altisimos montes, crecidisimos cedros; y ansi dice David al Señor: Tu justicia como los montes de Dios. De semejante modo de decir usan los Españoles, y otras naciones; que en engrandecer, y sublimar una cosa, 
Españoles y otras naçiones para usamos deste vocablo, divino, diciendo: ensublimar y engrandeçer vna cosa $\wedge_{q}$ Es un hombre divino, tiene una divina usamos del vocablo diuino diçiendo es eloqüencia". un hombre diuino tiene una diuina eloquençia".

(Texto M, pág. 244)

(Texto L, pág. 241)

8.- Hermana es a nos pequeña y pechos no tiene. ¿Qué haremos a nuestra hermana cuando se hablare de ella?

9.- Si hay pared, edificarle hemos un palacio de plata; si puerta fortalecerémosle para ella con tabla de cedro.

10.- Yo soy muro y mis pechos torres. Entonces fui en sus ojos, como aquella que halla paz.

Una vez que la Esposa se ha casado y tiene, por así decirlo, su vida resuelta, empieza a preocuparse por su hermana pequeña y le pregunta a su Esposo qué harán con ella cuando comiencen a hablarle de amor. El Esposo responde, no con poca ironía, que la encerrarán en un lugar que sea inaccesible; pero al final concluyen que todo esto no será necesario, ya que ellos forman una pareja fuerte, capaz de proteger a la hermana pequeña sin ningún problema. Éste es el sentido de la letra que ofrecen los textos $\mathrm{M}$ y L.

Pero, además de esta interpretación, $\mathrm{M}$ ofrece otra $\mathrm{y}$ dice que estos versos corresponden a la conversación que mantienen el Esposo y la Esposa cuando tratan la buda de la hermana de ésta, y como no es tan gentil como la Esposa, piensan que tendrán que aderezarla para que parezca lo que no es.

Ei sentido espiritual desarrollado por $L$ explica que esa hermana pequeña es la fe, a la cual es necesario cuidar y amamantar con los dos pechos de la Esposa, es decir, con los dos Testamentos, el Nuevo y el Antiguo. 
Veamos, una vez más, cómo expresan el comentario de la letra de estos versículos cada uno de los textos y, así, nos daremos cuenta del grado de identidad existente entre los dos textos:

L

"Despues que las mugeres estan casadas y por su parte contentas con sus buenos Esposos. sueleles acudir nueuo cuidado de remediar y poner en cobro las hermanas menores que en casa de sus padres quedauan, y comienzan dende entonzes a myrar por ellas y por su honrra y su Esposo les ajuda tomando por suyo el negoçio de las cuñadas $\mathrm{y}$ procurandolas guardar $\mathrm{y}$ honrrar hasta ^q las casen, este mismo cuidado se le muebe ahora a esta contentissima $\operatorname{Esp}^{a}$ y cuenta a su Esposo, como ellos tienen una hermana $\tan$ pequeña y que aun no le an nazido los pechos que es hermosa y como quiera que la major esta ya casada ahora no se ha de hablar sino de la menor que no faltaran nuebos enamorados para ella y simple con la niñez, no terna valor para rescatarse y mirar por sy por tanto que mire que la haran como la ampararan para $\wedge q$ ninguno se atreua a ofendella y esto diçe ahora la Espa para mas gloria de su Esposo como luego
M

"Despues que las mugeres estan casadas, y por su parte contentas con sus esposos, sueleles acudir un nuevo cuidado de remediar, y poner en cobro las hermanas menores, que en casa de sus padres quedan, y comienzan desde entonces a mirar por ellas, y por su honra, y los esposos les ayudan tomando por suyo el negocio de las cuñadas. Ese mismo cuidado le mueve a esta contentisima Esposa, y cuenta a su Esposo, como ellos tienen una hermaria pequeña, que aun no le han nacido los pechos, y que es hermosa, y por ser ansi no le faltaran nuevos enamorados; $y$ siendo como es moza, sencilla, y simple, no tendra valor para recatarse, y mirar por si; por tanto que es bien mirar como la guardaran, o que haran della, hasta que venga el tiempo de casalla; que eso es decir, el dia que se hablare della. A esto responden ellos mismos, diciendo, que sera bien tenella encerrada en un lugar que sea muy fuerte, y que si ha de ser edificio de paredes para ello, 
ueremos, hecha la pregunta responden ellos mismos diçiendo, sera bien tenella ençerrada en vn lugar ^ $q$ este muy fuerte y sera bien que si se ha de haçer edifiçio de paredes le hagamos una casa tan fuerte $\tan$ maciça $y$ lisa por de fuera como si fuera de plata hecha ${ }^{\wedge} q$ ny la puedan quebrantar mirandola ny subiria trepando por ella. y quando le hagamos la puerta la guarnezcamos de muy fuertes y durables tablas de çedro para $\wedge \mathbf{q}$ desta manera este bien guardada nuestra hermana.

I Estas palabras pareçen ser dichas burlando como si dixesen si por uia de guardar lo hemos de hazer hagamosla un palaçio fortissimo que no baste nadie a poder entrar donde ella esta mas en fin todo esto no es menester, $\operatorname{por}^{\wedge} \mathrm{q}$ no es menester gentil Esposa? Responde ella sy yo no estuuiera casada con tal Esposo como tengo tubieramos necesidad de tratar desos negocios para la guarda de my hermana mas ahora estando yo tan emparada con la sombra de mi Esposo $\tan$ honrrada con su nobleza. y tan acatada por causa de su grandeza no ay para que tener a my hermana ençerrada desa manera sino traerla conmigo. y unta a my y abraçada con mis pechos que sea $\tan$ fuerte, $\tan$ macizo, $y$ liso por de fuera, como si fuera de plata, que no le puedan quebrantar minandolo, ni subir por el trepandolo. $Y$ las puertas, dicen, de tal edificio, guarnezcamoslas de muy fuertes y muy durables tablas de cedro, para que desta manera este bien guardada nuestra hermana. Estas palabras parece ser dichas burlando, como si dixeran: si por via de guarda ha de ser, hagamosle un palacio fortisimo, que no baste nadie a entrar donde ella esta. Mas en fin, dice, todo esto no es menester, y la causa es por lo que añade:

10. Yo soy muro, y mis pechos torres, entonces fui en sus ojos, como aquella que halla paz.

Que es decir, si yo no estuviera casada con tal Esposo, como tengo, tuvieramos necesidad de tratar destos negocios para la guarda de mi hermana; mas ahora estando yo tan amparada con la sombra de mi Esposo, y tan honrada con su nobleza, y tan acatada por su causa, yo sola basto a hacer segura a mi hermana, no hay para que tenella encerrada desta manera; sino traheila yo junta conmigo, y abrazada a mis pechos, que no habra quien la ose a ofender; 
que no habra quieil ose a deçir vna minima ofensa $\operatorname{por}^{\wedge} q$ no ay muro tan reçio como yo ni ai torres tan reçias como mis pechos y esta fortaleza tengo yo en my para defender a quien a my se llegare desde entonçes quando yo començe a agradar a my Esposo y le pareçi bien a sus ojos que el començo a cuminicarme su amor".

(Texto L, págs. 242-243) porque no hay muro tan recio, como yo, ni torres tan fuertes como mis pechos: $y$ la sombra de mi seno, y esta fortaleza tengo yo desde el tiempo que comence a agradar a mi Esposo, y le pareci bien a sus ojos, y el comenzo a comunicarme su amor".

(Texto M, págs. 245-246)

11.- Una viña fue a Salomón en Bcial-Hamón. Entregó la viña a las guardas y que cada cual traía por el fruto mil monedas de plata.

12.- La viña mía, que es mía, delante de mi; mil para tí, Salomón, y doscientos para los que guardan su fruto.

Cuando estos dos esposos se han casado, la Esposa se encarga de la hacienda y la economía. Como ella tenía una gran viña decide ponerse a cuidarla ella misma, y no como hizo Salomón, que la arrendó. Así todos los beneficios serán para ella y no tendrá que repartir entre los arrendatarios. Éste es el sentido de la letra comentado por L y M.

El sentido espiritual lo comenta solamente L y dice que la viña de la Esposa es la congregación de los fieles que tiene a su cargo, y que cuida con esmero para que dé muchos frutos para su Esposo (Dios).

La letra de estos versículos del Cartar de los Cantares es comentada de la siguiente manera por ambos textos: 
"Despues que las mugeres se casan con buenos y horrados maridos para la sustentaçion de su familia es necessario ^q entiendan en llegar y guardar la hazienda y quanto mas honrrada es la muger y mas amada a su marido mas cuenta tiene con esto como claramente en las postreras lectiones de los prouerbios que a estos tales los fauoreçe Dios con poner en ellos el cuidado que puede y exercitarse en buenas artes qual es la agricultura, dales Dios fructos para cumplir las necessidades que en las familias le ofreçen luego que esta Espa se caso tan a su contento con su buen Esposo comienza a tener cuidado de su hazienda y esperar de auer gran prouecho, porque ella tiene muy buena viña como arriba le oymos deçir y como agora esta fauoreçida, con su Esposo ella terna gran cuidado de la guardar hasta $\wedge_{q}$ se coga el fructo $y$ no abra quien ose apartarla de guardar su viña como de antes harian los hijos de su madre y guardandola ella tambien como persona que se duele por ser suya la viña estara mas entero el fructo y retarle a mas y para decir esto usa de vn
"Despues que las mugeres se casan con buenos, y honrados maridos, para la sustentacion de su familia, necesario es, que entiendan en allegar, y guardar la hacienda; y quanto mas honrada es la muger, y mas ama a su marido, mas cuenta tiene con esto, como paresce en las postreras lecciones de los Proverbios. $\mathrm{Y}$ ansi luego que esta Esposa se caso a su contento, comienza a tomar cuidado de su hacienda, y esperar de haber gran provecho. Porque ella tiene una muy buena viña, como arriba le oimos decir; y como ahora esta favorecida de su Esposo, ella terna gran cuidado de la guardar, hasta que se coja el fruto, y no habra quien la ose apartar de guardar su viña, como antes hacian sus hermanos. Y ansi guardandola ella, como persona a quien le duele, estara mas entero el fruto de la viña, y rentara mas. Y para decir esto, usa de un argumento entre si desta manera: Salomon, Rey de Hierusalem, tiene una viña en aquel lugar, que llaman Bahalhamon, que quiere decir, señorio de muchos, como si dixesemos, en el pago de muchas viñas; $y$ esta viña arriendala 
argumento entero, $y$ en Esta manera, Salomon el Rey de Jerusalem tiene vna viña en aquel lugar ^ $\mathrm{q}$ se llama bahalamon que quiere decir sefforio de muchos como si dixesemos en el pago de muchas viñas y esta viña arriendala Salomon a vnos hombres para $\wedge q$ la guarden y labren y traigan mill monedas de plata (del valor çierto de aquel tiempo) por el fructo della y $\wedge \mathrm{q}$ ellos se ganen lo demas, y de aqui concluye la

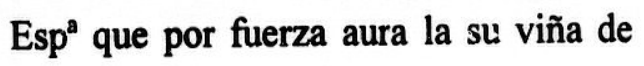
rentar mas $\wedge q$ no la de Salomon por^ $q$ ella la guarda que es propia señora y estara mejor labrada $\wedge q$ la otra por no ser sus dueños $y \wedge q$ no tienen tanta cuenta en labrarla y adereçarla como si fuera propria, y dice pues si la tuya Salomon te renta mil a ty y los $\wedge q$ la arriendan y guardan ganaran por lo menos la quinta parte que son dozientos $\wedge q$ me rentara la mya de quien yo terne tanto cuidado".

(Texto L, págs. 244-245)
Salomon a unos hombres, para que la labren, y guarden, $y$ le trahigan mil monedas de plata del valor cierto de aquel tiempo por el fruto della, y que ellos se ganen lo demas; $y$ de aqui concluye la Esposa que por fuerza su viña ha de valer mas, que no la de Salomon. porque la guarda ella, que es propria señora, y por la misma causa estara mejor labrada, que no la otra. Y dice, pues si la tuya, Salomon, te renta mil a ti, y los que la arriendan y guardan, ganan por lo menos la quinta parte, que son doscientos; que me rentara a mi la mia, de quien yo tendre tanto cuidado?".

(Texto M, págs. 250-252)

13.- Estando tú en los huertos y los compañeros escuchando, haz que yo oiga tu voz 
14.- Corre, amado mio, que parezcas a la cabra montesa y al ciervecito sobre los montes de los olores.

En estos últimos versículos del Cantar de los Cantares, el Esposo pide a su Esposa que, puesto que van a estar juntos, el uno apacentando y la otra cuidando su viña, cante de vez en cuando sus amores para con él y dé celos a los otros pastores. Ella, por su parte, le pide al Esposo que cuando lo llame desde su viña venga pronto a socorrerla. Éste es el sentido de la letra que comentan L y M.

Pero lo más importante de este comentario final es el sentido, que podíamos llamar espiritual, desarrollado en ambos textos y en el que se explica el por qué de esta obra, la razón de ser de este cántico amoroso. Por último, ambos textos concluyen dando gracias a Dios.

Veamos, por última vez, la exposición llevada a cabo por cada uno de los textos; así, podremos confirmar, de nuevo, la casi absoluta identidad que existe entre los dos textos.

"La viña de la Esposa no estaua muy lexos de los hue:tos como podemos colegir de lo ^ $q$ ella en el capitulo antes deste deçia combidando a su amado, al campo lebantarnos hemos de mañana y beremos las viñas. $y$ los huertns ets. de manera ^ $q$ estando ella en los huertos podia uer y guardar su viña y como el Esposo es pastor conueniale entre dia andar con su ganado, $y$ assy el uno en el pasto y la otra en la guarda de las viñas se ccupauan $y$ en adereçar tambien algunas cosas del huerto $\wedge \mathrm{q}$ esto competia a la Esposa y como quiera que
"La viña de la Esposa no esta muy iejos de los huertos, como podemos colegir de lo que ella en el capitulo de antes decia, convidando a su amado al campo: Levantaremonos de mañana, veremos las viñas, y los huertos, etc. De manera que estando ella en los huertos, podia ver, y guardar su viña. Y como el Esposo es pastor, conveniale andar en el campo entre dia con su ganado; $y$ ansi se ocupaban el uno en el pasto, y el otro en la guarda de las viñas, $y$ en aderezar tambien alguna cosa del huerto, que esto competia a la Esposa: mas como se 
ambos se amen tanto no querrian estar apartados vno de otro demas desto. suele acaezer ^q quando dos estan en gran conformidad de estrecho amor nunca faltan embidiosos que les pese dello ó por^q ellos no tengan amores, ó no tales, $y$ qualquiera cosa $y$ señal $\wedge q$ veen passar entre los buenos amantes les es enojosa $u$ graue, $y$ desto reçiben gran gusto los $\wedge q$ mucho se aman no solamente con estas muestras hazen pesar a los emulos, mas tambien se acreçienta su amor que pareze que el atizar del contrario los enciende mas el amoroso fuego de sus corazones, Esto es lo ^ q pasa en la letra presente que el Esp $^{\circ}$ diçe a su amada, quando tu estuuieres en los huertos guardando las viñas y yo andubiere por el campo apazentando el ganado por tu uida que algunas uezes cantes alguna cançion que pertenezca a nuestro amor de manera $\wedge q$ yo lo oyga y me goze mucho por ser iu voz que tinto yo amo y los pastores que estan escuchando rebienten de embiủia.

If La cancion que la Esposa dize para estos propositos de mostrar el amor suyo y de su Esposo y hazer rabiar a los malos. es la que esta luego en la letra que diçe, Esposo y mi amado gran amaban tanto, no quisieran estar apartados el uno del otro. Demas desto suele acaescer, que quando dos estan en grande conformidad de estrecho amor, nunca faltan envidiosos, que les pese dello, o porque ellos no tienen semejantes amores, o porque naturalmente son enviaiosos del bien ageno, y qualquier cosa, y señal que veen pasar entre los buenos amantes, les es enojosa, $y$ grave. $\mathrm{Y}$ desto reciben gran gusto los que mucho se aman, porque no solamente con estas muestras hacen pesar a los emuios, mas acrescientase su amor tambien; que parece que el atizar del contrario les ticiende mas el amoroso fuego de sus corazones. Esto es lo que pasa en la letra presente, que el Esposo dice a su amada: Quando tu estuvieres en los huertos, guardando tus viñas, y yo anduviere por el campo, apascentando el ganado, canta alguna cancion, que pertenezca a nuestro amor, de manera que yo la oiga, y me goce mucho por ser tu voz, que tanto yo amo; $y$ los pastores que estan escuchando rebienten de envidia. La cancion, que la Esposa dice para estos propositos, de monstrar el amor suyo, y de su Esposo, y hacer 
deseo tengo de uerte, no estes mucho sin uenir a uisitar a tu Esposa acude de quando en quando a uerla y quando uinieres no te estes en el camino, sino muestrame el amor $\wedge \mathrm{q}$ me tienes no solamente en uisitarme a menudo sino en venir mas ligero $\wedge \mathrm{q}$ la cabra montesa $y$ mas ^ $q$ el çerbezico que anida en los montes espesos donde ay çedros, terebintos, y otras plantas olorosas $\operatorname{por}^{\wedge} q$ bien sabes tu corrrer con gran ligereza no tardes corre amor mio uerdadero pues ne puedo ualerme sin ty con gran presteza acude a uerme".

(Texto L, págs. 245-246) rabiar a los envidiosos, es la que esta luego en la letra, que dice:

14. Corre, amado mio, que parezcas a la cabra montesa, y al ciervecito sobre los montes de los olores.Como si dixese, Esposo mio amado, gran deseo tengo de verte, no estes mucho sin venir a visitar a tu Esposa, acude de quando en quando a verla, y quando vinieres, no te estes en el camino, sino muestra el amor que me tienes, no solamente en visitarme a menudo, sino en venir mas ligero, que ia cabra montesa, y que el ciervecico que anda en los montes espesos, donde hay cedros, y theberintos, y otras plantas olorosas; porque bien sabes tu correr con gran ligereza: no tardes, corre, amor mio verdadero, pues no puedo valerme sin ti, con gran presteza acude a verme".

(Texto M, págs. 252-255) 


\section{CONCLUSIONES}

Las conclusiones que podemos obtener son de varios tipos, teniendo en cuenta las distintas perspectivas aesde las cuales podemos aborciar el texto:

1.- Conclusiones de tipo general.

2.- Conclusiones partiendo del contenido.

3.- Conclusiones acerca de la autoría del texto.

\section{1.- Conclusiones de tipo general.}

A) Teniendo en cuenta la extensión del texto tenemos que decir que es muy similar en ambos casos, aunque como sabemos el texto $L$ es más extenso, consecuencia lógica de ofrecer, en la mayoría de los casos, un doble comentario. Pero la diferencia en que L supera a M es minima.

B) Atendiendo a la distribución por capítulos nos damos cuenta de que, de igual forma, es idéntica en uno y otro texto, aunque también tenemos que decir que $\mathrm{M}$ suele hacer una pequeña introducción antes de iniciar cada capítulo dando cuenta de lo que en él se va a tratar. Pero esta introducción también la hace $\mathrm{L}$ una vez iniciados los primeros versos que se van a explicar en cada capítulo.

C) Tras el estudio de ambos textos, nos damos cuenta de que ni ei texto $M$, que anuncia en su título que va a ser un comentario según la letra, ni el texto L, que según su título va a ser un comentario según el sentido espiritual, cumplen su promesa y ambos comentan el sentido de la letra y el sentido espiritual. Por todo ello estamos de 
acuerdo con ul teólogo alemán Klalis Reinhardt que cree que sería mucho más acertado el título de otro comentario al mismo texto bíblico de Fray Luis que se encuentra en la Biblioteca Universitaria de Barcelona con e! número 1717 y que se titula Expositio litteralis et mistica.

2.- Conclusiones partiendo del contenido.

A) Conocemos por las traducciones que de los versículos del Cantar de los Cantares se hacen en los dos textos que son idénticos con sólo pequeñas variantes en $\mathrm{L}$, variantes que se refieren a palabras concretas que intentan dar mayor exactitud al texto y a su comentario. Variantes que, por otro lado, propone $\mathrm{M}$ y las toma directamente $\mathrm{L}$, por lo que vemos la continuidad que existe entre un texto y otro.

B) En cuanto al comentario de la letra, vemos que ambos textos, aún saltándose el imperativo de su título, lo exponen y además de forma idéntica. Esto ocurre casi siempre, salvo en algunos casos en los que $\mathrm{M}$ propone una doble lectura de algún pasaje. L, por su parte, casi nunca ofrece doble interpretación, lo que nos puede llevar a considerar a $\mathrm{L}$ como un texto posterior, con mayor claridad de lo que se dice y con mayor seguridad de cómo se está diciendo. También hay que comentar que, en algunos casos, muy pocos, los textos difieren bastante.

C) En lo que concierne al sentido espiritual tenemos que decir, de igual modo, que ambos textos lo abordan sin tener en cuenta su propósito inicial. Por supuesto, sobra decir que los comentarios espirituales de $\mathrm{L}$ son más ricos que los de $\mathrm{M}$; de igual modo, los comentarios de la letra de $\mathrm{M}$ son más ricos que los de $\mathrm{L}$.

D) En todo el comentario contrastivo de los contenidos de ambos textos no hemos hecho mención, en ningún momento, al comentario según el sentido anagógico del texto, ya que sería muy complicado hacer distinción entre comentario espiritual y anagógico. Pero tenemos que decir que esta forma de interpretación se da también en $\mathrm{L}$ y consiste en llevar a su último extremo el comentario espiritual y ver en esos amores 
de los Esposos la relación Dios-Iglesia, Iglesia-comunidad cristiana, comunidad cristiana-comuniciades no cristianas, etc. Esto da pie a asegurar que con el texto $\mathrm{L}$ estamos ya muy próximos a lo que fue la Triple explanatio de Fray Luis de León. Además nuestro agustino estaba convencido de que este comentario según el sentido anagógico era el culmen de todos los demás y el que había de ponerse como meta; pero para llegar a él era necesario pasar antes por los anteriores.

3.- Conclusiones acerca de la autoría del texto.

A) Ante dos obras con un paralelismo tan asombroso, aunque en sus títulos afirmen que van a tratar cosas distintas, tenemos que guiar nuestras sospechas acerca de la autoria hacia un punto muy concreto, que las dos obras sean dei mismo autor.

B) Es muy dificil que dos autores puestos a realizar dos obras distintas, como sería este caso, pero sobre la base de un mismo texto, coincidan no sólo en las citas bíblicas que aportan para la aclaración del texto, que sería algo normal, sino también en todos los ejemplos tomados de la flora, fauna y vida cotidiana de un pueblo, el hebreo, contrapuesto a otro modo de vida, el occidental. En verdad, si se tratara de un plagio, creemos que no es posible plagiar de este modo.

C) Sabemos, además, por la innegable autoridad del P. Merino que su texto, cotejado con diversos manuscritos de la Biblioteca de la Academia de la Historia, es el que escribió Fray Luis de León. Este argumento es afianzado también por otros insignes padres como Félix García y Ángel Custodio Vega, entre otros. Por otro lado, en el texto L se da el nombre de Fray Luis de León como autor del texto. Por fin, también nos constan las sucesivas elaboraciones que sufrió el texto del Comentario del Cantar de los Cantares a lo largo de la vida de Fray Luis de León y realizadas por él mismo, hasta desembocar en In Cantica Canticorum Salomonis Explanatio, realizada por expreso deseo de sus superiores de la orden agustiniana. Esto nos ayuda a afirmar la evoiución que se produce de $\mathrm{M}$ a $\mathrm{L}$. 
D) Por todo ello parece claro que el único problema que ya se nos plantea es afirmar que el texto es de Fray Luis de León cosa que afirmamos, aunque quedamos siempre dispuestos a cambiar nuestra afirmacióni si apareciese algún nuevo documento que invalide todo este estudio y sus conclusiones. 
EXPOSICIÓN DE LOS CANTARES DE SALOMÓN POR EL PADRE

FRAY LUIS DE LEÓN SEGÚN EL SENTIDO ESPIRITUAL 


\section{PROEMIO \\ SOBRE LA EXPOSICIÓN DE LOS \\ CANTARES DE SALOMÓN \\ POR EL PADRE \\ FRAY LUIS DE LEÓN \\ SEGÚN EL SENTIDO ESPIRITUAL}

Es tan grande el amor que Dios tiene a los hombres $y^{\prime}$ tanto el deseo que tiene de ser de ellos amado ${ }^{2}$-para que, amándole, gusten de los sentimientos de su paterno regalo ${ }^{3}$ - que, por cuantas vías y maneras hay, los procura siempre traer a sí y darles a conocer lo que pierde quien no le ama como debe, $y$, por el contrario, con cuánta ganancia torne al amador la afición 5 que en él se emplea. De donde viene que el Espíritu Santo, perfecto conocedor de nuestros interiores afectos y movimientos, nos procura siempre inducir a este amor por diversos modos: unas veces, contándonos las maravillas que Dios ha hecho en la creación del mundo y su prudente gobernación, mostrando $\operatorname{ser}^{6}$ criado y sustentado para el servicio del hombre y contando las cosas de grande hazaña que por él ha obrado en todo el proceso de la vida; otras veces, amenazándole con el azote de la ira, y otras veces, consolándole con los regalos de misericordias, y muchas otras, convidándolo y requiriéndolo con dulces requiebros de afecto; y todo esto a fin [de] ${ }^{7}$ que, por agradecimiento, por temor, por amor o por vergüenza, haga lo que le manda, que es aquello que debe hacer para su bien andanza de esta vida y eterna felicidad de la otra. De semejantes argumentos y persuasiones están llenas las Histcrias Sagradas, las oraciones y sermones proféticos, los versos y canciones del salmista, así como los consejos de la Sabiduría y, finalmente, las pláticas, conversaciones y obras de luz, vía y verdad, abreviador y fidelísimo intérprete de la doctrina del Padre.

Pues, entre las obras y tratados de las Divinas Escrituras en que Dios declaró ${ }^{8}$ su voluntad y amor a la humana naturaleza, una es la canción suavísima que Salomón, profeta y hijo de

\footnotetext{
${ }^{1} Y$ : respetanios la forma original de las conjunciones copulativas y disyuntivas. Por ello, no se encontrará en nuestro texto el uso de los alomorfos $e$ y $o$ para evitar !as cacofonias

${ }^{2}$ De ellos amado: construcción de complemento agente con la preposición de, en lugar de por, más habitual actualmente. Se trata de un uso de época, muy frecuente en nuestro texto

${ }^{3}$ Regalo: conveniencia, comodidad o descanso que se procura en orden a la persona (DRAE, 4). Es muy frecuente en este texto, refiriéndose a la relación entre el Esposo y la Esposa, e! uso de toda la familia de derivados de regalo, utilizados precisamente en este sentido.

${ }^{4}$ Traer: atraer.

${ }^{5}$ Afición: la propensión, amór, ó voluntad del ánimo con que nos inclinamos à querer y amar alguna cosa (D. Aut.).

${ }^{6} \mathrm{Ser}$ : inicia una proposición completiva de infinitivo. Es una construcción típicamente latina, que resulta habitual a lo largo de todo nuestro texto. En castellano actual su uso es más restringido, siendo frecuente cuando el sujeto de la proposición subordiada es el mismo que el de la principal.

$\left.{ }^{7} \mathrm{De}\right]$ : en nuestro trataniiento del texto nos serviremos de los corchetes siempre que insertemos algo. Las adiciones irán encarninadas a uno de estos dos fines: por un lado -como es este caso- dados los ohjetivos de nuestro trabajo, para acercar la lengua del texto a la actual, pero dejando claro qué pertenezca a la lengua original y qué no; por otro lado, para intentar rehacer el texto en aquellos lugares donde aparezca mutilado.

${ }^{8}$ Declarar: en la mayoría de las ocasiones, aparece con el sentido de aclarar cxplicar.
} 
David, compuso. El cual, debajo de semejanza de una amorosa y pastoril égloga, nos da a entender cuáles sean los efectos que el divino amor produce en aquellos que de sus llamas son encendidos. Porque ${ }^{10}$, introduciéndonos los respondientes ${ }^{11}$ razonamientos de dos enamorados, es decir ${ }^{12}$, Esposo y Esposa ${ }^{13}$, los cuidados en que está el uno por el otro, los afectos que en sí sienten provocan a cualquier alma humana a dejarse vencer de tal amor y querer sentir parte de sus gustosísimos regalos. Aquí se ven pintados al vivo ${ }^{14}$ los amorosos juegos de los divinos amantes, los encendidos deseos, los perpetuos cuidados, las recias congojas que la ausencia y el temor (que) ${ }^{15}$ en ellos causan, juntamente con los celos y sospechas que entre ellos se mueven; aquí se oye el sonido de los ardientes suspiros, mensajeros del corazón, y de las amorosas quejas y dulces razonamientos, que unas veces van vestidos de esperanza, otras de temor, otras de tristeza, otras de alegría y, en breve, todos aquellos sentimientos que los apasionados amantes probar suelen ${ }^{16}$; aquí se ven tanto más agudas y delicadas cuanto más vivo y acendrado es el divino amor que el humano.

Concuerdan todos los intérpretes, así hebreos y caldeos como griegos y latinos, en la declaración de los dos desposados, haciendo a Dios el Esposo y a la congregación de los fieles la Esposa, porque de este sagrado desposorio tenemos manifiesta probanza en la Sagrada Escritura ser celebrado así por promesas y palabras de futuro, enviando Dios por tercero a su profeta Isáias ${ }^{17}$ : Con estas juras, ella me llamará el mi amado y yo seré para siempre el su Esposo $^{18}$. Y este misterio trata Ezequiel en todo el capítulo $17^{19}$. También David ${ }^{2 n}$, por

\footnotetext{
${ }^{9}$ Semejanza: entiéndase apariencia.

${ }^{10}$ Porque: esta conjunción, además de aparecer con los valores causal y explicativo, usuales actualmente, puede encontrarse también en nuestro texto con un valor final, que, aunque no está totalmente abandonado en nuestra época, tiene un claro sabor arcaico. Señalaremos los casos en
} que esto ozurra.

${ }^{11}$ Respondientes: correspondientes. El verbo responder y todos sus derivados, pueden aparecer, bien en su sentido propio actual, bien en este de corresponder.

${ }^{12}$ Es decir: en el manuscrito, $s$

${ }^{13}$ Esposo y Esposa: en el manuscrito alterna la escritura completa de estas palabras con las abreviaturas Esp ${ }^{\circ}$ y Esp

${ }^{14}$ Al vivo: con la mayor vivez, c on suma expresión y' eficacia (DRAE).

${ }^{15}$ (Que): utilizaremos el paréntesis, rormalmente, cuando propongamos alguna supresión, bien de cara a la modernización, bien por resultar algün elemento incoherente (lo que ocurre, normalmente, debido a la mala transmisión del texto). Proponemos aqui la supresión de este elemento que rompe la estructura sintáctica.

${ }^{16}$ Probar suelen: a lo largo del texto puede observarse, en determinados casus, cierta influencia latina en el orden de palabras. Asi ocurre aqui, donde el castellano moderno no colocaria el verbo al final de ia oración, tras el infinitivo, sino en orden inverso.

${ }^{17}$ Isaias: suele aparecer en el manuscrite con la forma Esaias. A partir de ahora, en relación a los nombres propios -que han sido actualizadosanotaremos, en general, aquellos casos en las que en el manuscrito se den variantes de trasncripción -que han sido homogeneizadas- 0 grandes diferencias con la transcripción actual. No haremos mención de aquellos casos en los que se den meramente variaciones ortográficas o fonéticas habituales.

${ }^{18}$ En anotación al margen en el manuscrito, se adscribe esta cita al capitulo 2 de Isaias. La anotación es errónea; en realidad pertenece a 1 saias $(6,6-13)$. En numerosas ocasiones estas referencias marginales a las citas son erróneas $\mathrm{c}$ incompletas. Iremos corrigiéndoias y completándolas a lo iargo de todo el texto. De cara a las variaciones existentes entre las diversas ediciones de la Biblia, aclaramos que la edición con la que hemos trabajado ha sido la de Ediciones Paulinas, décimo tercera edición, Madrid, 1982.

${ }^{19}$ Nuevo error. Se trata de Ezequiel $(36,28-29)$.

${ }^{20} \mathrm{Sa}$ (44), Poema nupcial al rey mesiánico. El cambio de numeración se debe a haber sido unidos en la Biblia los salmos 9 y 10. 
representación de Salomón y de la hija de Faraón, en una muy suave y levantada ${ }^{21}$ canción, celebra y regucija estas bodas. Después, por palabras de presente, dando testimonio [de] cómo está hecho el desposnrio por la voz de su pregonero y embajador San Juan ${ }^{22}$. Y, como quiera que cada ánima fiel y miembro de esta Iglesia sea parte, ninguno se puede quejar con razón de no tener parte en el desposorio, salvo si por sucia malicia se quisiese salir fuera de él.

El autor de este Cantar dijimos ser Salomón, como el mismo título nos le enseña, que dice Cantar de cantares de Salomón. Uso es de la lengua hebrea, cuando quiere señalar una cosa excelente, decirla por este modo: "santo de los santos, rey de los reyes"; y, así, Cantar de los cantares tanto quiere decir como excelentísimo cantar sobre todos; porque los otros cantares que en la Escritura se hallan debajo de esta voz , que es en diez $^{23}$, no celebran tal materia o no tan copiosamente [como] en este, que nos muestra el amor divino, cuya declaración será buena [en] cuanto solamente se pueda abrir la puerta para que los enamorados corazones, entrando más adentro, gocen de más altos misterios y más subida ${ }^{24}$ doctrina, tal cual el Apóstol dice: Comunicamos la sabiduría a los perfectos, y esta sabiduria no es de este siglo.

\section{[EXPDSICIÓN \\ DE LOS \\ CANTARES DE SALOMÓN]}

\section{CAPÍTULO ${ }^{25}$}

[iBéseme de los besos de su boca!, porque los tus ${ }^{26}$ amores son más dulces que el vino. Al olor de los preciosísimos ungüentos tuyos. Ungüerto vaciado es el tu nombre; por eso las doncellas te aman. ¿Llévame! Tras ti correremos. Metióme el rey en sus retretes. Negra soy,

\footnotetext{
${ }^{21}$ Levantado elevaio, sublime (DRAE, 2)

${ }^{22}$ En el manuscrito, San Juan (3). En concreto, San Juan (3, 25-36)

${ }^{23}$ Que es en diez: que aparece diez veces en la biblia.

${ }^{24}$ Subido: dicese de lo ùltimo, más fino y acendrado en su especie (DRAE, 2). Véase nota 21

${ }^{25}$ CAPITULO I: hemos suprimido aqui las palabras DE LOS CANTARES, con la única intención de homogeneizar el modo de titular los diferentes capitulos

${ }^{26}$ Los tus: uso arcaico de pronombre acompañado de articulo. También se da este uso del articulo acompañando a demostrativos.
} 
mas $^{27}$ hermosa, hijas de Jerusalén ${ }^{28}$. Como las tiendas de Quedar ${ }^{29}$ y las tiendas ae Salomón. No me miréis, que soy morena, porque me miró el sol. Los hijos de mi madre arremetieron contra mi y pusiéronme a guardar las viñas y la viña mía no guardé. Hazme saber tú, a quien mi alma ama, dónde apacientas, donde huelgas ai mediodia. ¿Por qué andaré yo rebozada ${ }^{30}$ por las manadas de tus compañeros? Si no te sabes, ;oh bellisima entre las mujeres!, sal de tu morada y sigue las pisadas de las ovejas y apacienta tus cabriios junto a la majada de los pastores. A la caballería mía en los carros de Faraón te asemejé, amiga mía. Bellas son tus mejillas con sus ornamentos y tu cuello con sus collares. Joyas de oro te haremos con remates de plata. Cuando el rey estaba reclinado a la mesa, el mi nardo dio su olor. Envoltorio de mirra es el mi amado para mi, y entre mis pechos estará; racimos de cánfora ${ }^{3 /}$ el mi amado para mi en las viñas de Engadi ${ }^{32}$. ¿Cómo eres hermosa, amiga mía, cómo eres hermosa y tus ojos de paloma! ¡Y tú eres hermoso, amor mio, y también gracioso! Nuestra cama es florida y nuestras casas son de cedro; nuestros corredores, de cipreses. $]^{33}$

\section{[EXPOSICIÓN] $^{34}$}

¡Béseme de los besos de su boca!, porque los tus amores son más dulces que el vino.

Es tan grande y tan insaciable el deseo del enamorado que ninguna cosa le satisface, si no es verse de tal manera unido con la cosa que ama que, en cuanto es posible, de ambos tos se haga uno. Porque los que bien sintieren ${ }^{35}$ qué cosa sea amor lo darán a enterider de esta manera. Amor es una ánima que vive en dos cuerpos y el fin suyo es gozar y este gozo se viene a cumplir cuando de aquellos dos cuerpos se hace uro en la manera que mejor puede, de tal

\footnotetext{
${ }^{27}$ Mas esta conjunción adversativa aparece en nuestro texto principalmente con dos valores: uno -como este caso- equivalente a pero, en un uso también astual, y otro equivalente a sino, en uso más extraño al hablante moderno. Por ello, anotaremos las ocasiones en que posea este scgundo valor

28 Jerusalen muy diversas son las formas en que se encuentra esta palabra en el manuscrito: Hierusalem, Hierusalen, Herus.?'em, Jerusalem, Jerusalen.

${ }^{29}$ Quedar: en el manuscrite Çedar

${ }^{30}$ Revozar Cubrir casi todo el rostro con la capa o manto (DRAE, 1)

${ }^{31}$ Cänfora canfor alcanfor producto sólido, cristalimo, blanco, urente y de olor penetrante caracteristico. Se obtiene del árbol de su nombre tratando las ramas con una corriente de vapor de agua (DRAE)

${ }^{32}$ Engadi aparece en el manuscrito con la forma Eirgaddi

${ }^{33}$ En el manuscrito, aparece copiado el texto completo de cada capitulo de la traducción del Cantar desde el capítulo tercero en adelante. Lo restituimos nosotros en los dos primeros -a partir de los textos que aparecen citados al principio de cada parágrafo-, en un intento de homogeneización

${ }^{34}$ [EXPOSICIÓN]: introducimos este titulo al comienzo de la exposición de cada uno de los capitulos

${ }^{35}$ Sinticren: forma de futuro imperfecto de subjuntivo, acutalmente en desuso, relegada casi únicamente al lenguaje juridico. En su lugar suele utilizarse el pretérito imperfecto de subjuntivo. Es frecuente su aparición a lo largo de todo nuestro iexto.
} 
$\operatorname{arte}^{36}$ que ya son un cuerpo y una ánima ${ }^{37}$. De aquí vienen los abrazos entre los que bien se quieren, que representan aquesta ${ }^{38}$ unión; de aquí también los besos, que no solamente significan grande amor y paz, mas $^{39}$ muy más enteramente parece que imitan los dos amantes, juntando el espíritu y huelgo ${ }^{40}$ del uno con el del otro, como $\mathrm{si}^{41}$ ya con un mismo respirar ambos viviesen.

Dice pues la enamorada Esposa: "Es tan grande el amor que a mi Esposo tengo que ninguna cosa me contenta fuera de verme unida y junta con él. Mucho me alegran sus nuevas mensajerías, mucho las consolaciones y visitaciones que por su parte he recibido de los profetas y santos padres, los cuales me han dicho que él me ama y quiere muy mucho; mas todavía tengo sospecha [de] que no me quiere tanto como yo deseo, y por ventura ${ }^{42}$ es por no merecerlo yo. Mas, si él tanto me ama, muéstremelo para que yo descanse y viva contenta y alegre fuera de todo temor y sospecha; ivenga, venga ya aquel mi querido; muéstreme su presencia, la cual solamente puede dar eterna alegría! Y, porque ciertamente mi deseo [sea] cumplido, muéstreme el amor que me tiene, dándome siquiera alguno o algunos de los dulcísimos besos de su boca misma, haciéndose de esta manera un cuerpo conmigo, porque entorces teridré entendido que él ningún enojo, antes suma paz, tiene conmigo, cuando me consolare con sus besos dulcísimos y certísimos ${ }^{43}$ prenda de amor".

Estos besos que aquí la Esposa desea es ${ }^{44}$ la Evangélica Doctrina, hablada y publicada por la boca de Cristo ${ }^{45}$; dulcísimos besos de diez sonitos ${ }^{46}$ que aquí la Esposa demanda, los cuales tienen fuerza de juntar [a] los enamorados de Dios con él mismo y hacerlos de naturaleza divina y a Dios hacerio humano, de manera que los hombres, por medio de este amor, se puedar. llamar Dios, y Dios hombre. De aquí viene que [a] todós los enamorados ílama el Espíritu Santo, por boca del Apóstol, "miembro[s] de Cristo" y, en otra parte, "herederos con Cristo del reino de los cielos", pues qué mayor unión puede ser que esta: que de Cristo y de sus fieles enamorados se haya hecho un cuerpo y que, donde hasta aquí no había más de un

\footnotetext{
${ }^{36}$ De tal arte: de tal modo.

${ }^{37}$ Una ánima: no se da aún el uso actual, dirigido a evitar las cacofonias, de las formas el y un con sustantivos femeninos comenzados por $a$ tónica. Aparecen, además, sustantivos con género diferente al actual. Respetamos las formas originales.

${ }^{38}$ Aquestc: forma arcaica de demostrativo, equivalente a la moderna esta.

${ }^{39}$ Mas: equivalente a sino

${ }^{40}$ Huelgo: aliente, respiracion, resuello (DRAE, 1).

${ }^{41}$ Como si: introduce una oracién completiva dependiente de imitan

${ }^{42}$ Por ventura: quizá

${ }^{43}$ Certisimos: aunque concuerda con besos, resulta más lógicu que se refiera a prenda.

${ }^{44}$ Es: según la disposición de lá oración, deberia ir en plural, concordando con estos besos

${ }^{45}$ Cristo: aparece frecuentemente en el manuscrito con la abreviatura $x^{\circ}$

${ }^{46}$ Sonitos: sonidos.
} 
heredero del reino de los cielos, que era el hijo de Dios solo, $(y)^{47}$ ahora ${ }^{48}$ sea el hijo de Dios con sus miembros, quiero decir, con aquellos que con fe y amor se hicieron uno con él, con la unión de la gracia divina y virtud del Espíritu de Dios. Estos, pues, eran los besos que deseaba la Iglesia en el tiempo de Salomón, estos ha ya recibido y estos debe desear cada amador de Dios particular con firme fe y esperanza de recibirlos, como promete San Juan diciendo: [A] todos cuantos lo recibieron les dio poder para que fuesen hechos hijos de Dios y de divina naturaleza. Dice luego ${ }^{49}$ : Los cuales no son nacidos de sangre, ni de voluntad de carne, ni de voluntad de varón, sino de Dios son nacidos ${ }^{50}$, queriendo significar que ya tiene[n] mudada la naturaleza del viejo hombre carnal y están hechos otros hombres nuevos y espirituales, divinos hijos de Dios hechos de una misma frisa y un mismo cuerpo con su hijo Jesucristo. $Y$ esto, cómo se hace, lo declara el mismo evangelista, diciendo: Por el verbo, que es el hijo de Dios, se hizo carne y moró entre nosotros ${ }^{51}$. Donde claramente se muestra cómo, por este fiel amor, viene Cristo a hacerse un cuerpo y una persona con el que le ama, pues dice que él moró entre nosotros. ¡Oh! ¡Cuán dulce gozo es aquel del que dentro de sí siente habitar ese divino verbo! ¡Cuán dulces son los besos que recibe y cuánta suavidad debe hallar en ellas el que tales amores trata! Pues, que no alcanzando la Esposa cómo mejor los declara ${ }^{52}$, dice por comparación:

\section{Porque tus amores son mejores que el vino.}

Suele el vino hacer los mismos efectos en los que lo beben: quita los cuidados pasados, toca el corazón con nuevas y sensibles esperanzas, como vemos en los que están beodos ${ }^{53}$, que se imaginan príncipes y grandes señores, ponerse muy contentos sin memoria del trabajo ${ }^{54}$ pasado, lo cual todo procede de la alegría que el vino pone en el corazón, como lo manifiesta el dulcísimo cantor David, diciendo: El que produce el pan de la tierra y el vino para alegrar el corazón del hombre ${ }^{55}$, de la cual alegría nacen palabras regocijadas, cantares y gestos extraños, como la experiencia nos lo enseña.

Dice pues la enamorada Esposa que los amores de su Esposo más virtud sin comparación tienen que el vino, porque la suavidad y ricas esperanzas -que dentro, en el divino enamorado,

\footnotetext{
${ }^{47}(Y)$ : suprimimos la conjución copulativa. El motivo es que la oración que la sigue no está coordinada con la anterior, puesto que la primera funciona como complemento oracional de la segunda.

${ }^{48}$ Ahora: en nuestro manuscrito alterna esta forma con la aún no evolucionada agora. En la actualización, hemos homogeneizado en la forma moderna, de modc que aparecerá siempre ahora.

${ }^{49}$ Luego: prontamente, sin dilación (DRAE, 1). Este adverbio suele tener, en la época de nuestro texto, este sentido de mayor inmediatez que el gue posee actualmente

${ }^{50}$ En el ınanuscrito, San Juan (1). Concretamente, San Juan (1, 1-18).

${ }^{51}$ Perteneciente al mismo capitulo de San Juan antes sefialado.

52 Declara: tratánciose de una proposición interrogativa indirecta, lo usual actualmente es construirla con subjuntivo.

${ }^{53}$ Beodo: embriagado o borracho (DRAE).

${ }^{54}$ Trabajo: penalidad, molestia, tormento o suceso infeliz (DRAE, 7). Se trata de una doble acepción de la palabra (con este sentido y con el más actual) paralela a la del término latino labor

${ }^{55}$ En el naanuscrito, Salmo 103 (104). El titulo del Salmo es La gloria de Dios en la creación.
} 
se hallan-, los regocijos y cantares que de alli nacen, muy mayores ${ }^{56}$ son con infinito exceso que los que suele causar el vino. Por lo cual, David nos convida a esta suavidad, diciendo: Probad; veréis cuán suave es el Señor ${ }^{57}$. Y que los que de estos amores están beodos, gustando de esa dulzura, pierdan todos los temores y tristezas y se vistan de grandes ánimos y grandes esperanzas, manifiesto se ve en los Apóstoles ${ }^{58}$, que, siendo primero tan medrosos y pusilánimes que unos al estruendo de los que le[s] venían a prender huían, otros fácilmente a la pregunta de una sierva lo negaban; después que vinieron al entero gusto de estos suaves amores con la venida del Espíritu Santo, que sobre ellos descendió a hacerlos uno con Cristo, no temían todo el poderío de los príncipes del mundo; antes, con gran alegría y espantosa osadía, hablaban y predicaban loores de su enamorado Jesucristo, como se ve en San Pablo y en los demás Apóstoles cuando se paraban a disputar con el Concilio de Jerusalén, de los cuales se dice: Partianse del Concilio gozosos, porque eran tenidos por dignos de sufrir injurias por el nombre de Jesucristo. Queriendo pues probar la Esposa enamorada cuánto sean dulces y suaves los amores de su Esposo, dice:

\section{Al olor de los preciosisimos ungüentos tuyos.}

Esta razón esta pendiente ${ }^{59}$, como se muestra por un acento hebreo que en ella hay denotanto saitarse algo para cumplir la sentencia que en ella hay, que en aquella lengua se llama mirugh. Lo cual es costumbre a los enamorados y apasionados, que comienzan a decir y dejan las razones sin acabar, como es aquello de David: Los tus altares fortísimos, Señor ${ }^{60}$. Y así hay muchos lugares en la Escritura, que todos no los entienden por el autor, porque el autor estaba con pasión, y el que lo ve va sin ella y le parece algarabía, lo cual entendido le parecería dulcísimo y elegante.

Dice pues la Esposa: "¿Queréis entender, dulcísimo Esposo, cuánto sea suave el gusto de tus $^{61}$ amores? Solo el olor de tus ungüentos y sola la fama de tus maravillas, de tus grandezas y virtudes, de las cosas admirables que por tu pueblo has hecho han venido y trascendido por todas las naciones y provincias del mundo; demás ${ }^{62}$ [de] que todos empiezan [a] encenderse en tu amor y a ponerse en orden y aderezarse para ponerse delante de tu presencia y darse al servicio del amor tuyo; el cual, gustado ${ }^{63}$, es sobre todas las suavidades suave y sobre todas las dulzuras dulce". Gran argumento es este y fuerte prueba de los dulces gustos del divino amor, porque ordinariamente el olor es un adalid y espía de las presas que el gusto pretende hacer; y,

\footnotetext{
${ }^{56}$ Muy mayores: uso de la construccion superlativa sobre la base de un adjetivo en grado comparativo.

${ }^{57}$ En el manuscrito, Salmo 33 (34). El titulo del Salmo es Dics protector del justo.

${ }^{58}$ En el manuscrito, Acta 4 del Concilio de Jerusalén. Esta es la única cita que aparece en el manuscrito no extraida de la Biblia. También en la Biblia se puede encontrar en Hechos de los Apóstoles (5, 40-42)

${ }^{59}$ Está pendiente: es decir, que se da en ella un anacoluto

${ }^{60} \mathrm{La}$ anotación del manuscrito no resulta claramente legible. Podria tratarse de un 5 o un 9 . En cualquier caso, esta cita no se encuentra en ninguno de los Salmos 1-10.

${ }^{61}$ Queréis... ttss: mezcla de distintas formas de tratamiento.

${ }^{62}$ Demćs: además. Dado que !a forma demás aparece tambièn en su uso actual normal como adjetivo, anotaremos las ocasiones en que tenga función de adverbio (equivalente a además) como en este caso.

${ }^{63}$ Gustado construcción participial absoluta. Uso paralelo al latino.
} 
así, vemos que todos comen con mejor gana lo que les huele bien, y aborrece[n] lo que les da grave ${ }^{64} \mathrm{o}$ mal olor, dende por el olor rastreamos lo que creemos que nos ha de dar buen gusto y aprovechar. Y, queriendo declarar la Esposa qué sea este olor de su Esposo, prosiguiendo, dice:

Ungüento vaciado es el tu nombre; por eso las doncellas te aman.

El hebreo dice: Ungüento de evacuación es el tu nombre. "Este ungüento, Esposo mío, y este licor tan oloroso que he dicho [es] el nombre y fama tuya ${ }^{65}$, el cual mientras más se esparce más huele". Y así se ve claramente que, por la predicación de los Apóstoles y por las nuevas de la santidad, doctrina y maravillas de Cristo, andaba $(y)^{66}$ a la fama con clarísima trompeta publicando la majestad de su nombre y la grandeza de sus loores a los oídos del universo, de tal arte que todos, atraídos por la admiración, eran forzados a amarle. Y de esta publicación y claro testimonio [encontramos una muestra] en el profeta y en el Apóstol, que dicen: En toda la tierra salió su sonido, hasta los fines de la redondez su palabra. Y, porque la algalia $^{67}$-cierto licor de suavísimo olor- y otros olorosos licores suelen esparcer gran olor de sí cuando se vacían de un vaso en otro y se reparten en sus vasos, y entonces todos los que pasan por la parte donde se vacía se detiene[n] por gozar de aque!la suavidad y los vecinos suelen pedir un poco de aquel oloroso licor, principalmente las doncellas; por eso ${ }^{68}$ la Esposa, prosiguiendo debajo de aquesta metáfora, dice: "El tu nombre y fama [son] tan excelente[s] porque $^{69}$ sólo [con] el olor suyo, que se esparce y derrama por diversas partes de la tierra, muchos acuden a sentir de esta suavidad; y las doncellas sin placeres y puras, que pretenden seguir el camino puro de la limpieza, te aman mucho y corren a participar de tus ungüentos, y que por el tu nombre se entienda la fama gloriosa de alguno ${ }^{70 "}$. En las Divinas Escrituras está claro por lo que dice Salomón: Más es de procurar buen nombre que abundancia de riquezas $^{71}$. Y David dice: Anunciaré tu nombre a mis hermanos ${ }^{72}$.

\section{¿Llévame! Tras ti correremos.}

Enamorada y encendida la Esposa, dice: " $¡$ Oh, dulcísimo rey mío! Bien tengo entendido que el haber yo de gozar de tus regalados amores no lo puedo alcanzar por mí, aunque puedo desearlo y proseguir mi deseo con agradarte lo más que en mí sea; mas el venir a alcanzarte tú

\footnotetext{
${ }^{64}$ Grave: molesto, enfadoso (DRAE, 8). Acepción más cercana a la del latín gravis que la usada con más frecuencia acutalmente.

${ }^{65}$ El nombre y fama tuya el posesivo concuerda únicamente con el sustantivo más cercano a éi.

${ }^{66}(Y)$ : suprimimos esta conjunción que rompe la estructura sintáctica.

${ }^{67}$ Algalia: Substancia untuosa, de consistencia de miel, blanca, que luego pardea, de olor fuerte y sabor acre. Se saca de la bolsa que cerca del ano tiene el gato de algalia y se emplaa en perfumeria (DRAE).

${ }^{68}$ Por eso: se retoma la construcción comenzada cinco lineas más arriba $(Y$, porque...)

${ }^{69}$ Porque: conjunción causal en una construcción de claro sentido consecutivo

${ }^{70} Y$ que... alguno: la relación sintáctica de estas palabras con lo anterior resulta oscura

${ }^{71}$ En el manuscrito, Proverbios (22). Concretamente en Porverbios $(22,1)$.

${ }^{72}$ En el manuscrito, Salmo 21 (22). El Salmo se titula Oración del justo agonizante.
} 
lo has de saber, esperándome, asiéndome ${ }^{73}$ por la mano, llevándome tras ti, porque todo mi bien de tu gracia viene y porque sé que quieres ser seguido con gran diligencia de aquellos que tú llevas tras ti; yo prometo (de) $)^{74}$ ir corriendo porque ${ }^{75}$ nunca me dejes, no te pierda yo de vista, teniendo por cierto que perdiéndote quedo yo perdida, desconsolada y sin bien ninguno". Esta cláus[ul]a se ha de leer en distinción de esta manera: ¡Llévame! Tras ti correremos, porque, cuando el Esposo guía a su Esposa, sería gran disparate correr tras otro, por eso dijo: Tras $t i$ correremos. Este correr de la Esposa es darse priesa ${ }^{76}$, estar encendida, vivir en perfecta fe y caridad, conforme a la doctrina del Señor, dejadas todas las otras sectas de la gentilidad. Y así es aquello que dice San Pablo a los Gálatas: Corríades bien y andábades" fervientes en el curso de la buena intención cristiana ${ }^{78}$.

\section{Metióme el rey en sus retretes ${ }^{79}$.}

Porque el que ama ha de estar primero movido, encitado ${ }^{80}$ de algún conocimiento de aquello que ama, siendo necesario que la voluntad, madre del bien querer, esté persuadida de [que] aquello que se le ofrece delante es en alguna manera hermoso, porque ${ }^{81}$ luego ella ate su voluntad a la afición de aquella cosa; por esto ${ }^{82}$ dice la Esposa: "Metido me ha el rey en sus retretes, que es el conocimiento del mismo don, viendo yo la grandeza de sus hermosuras, la magnificencia de su liberalidad y la fortaleza de su poder, con todas las otras cosas que a un rey parece que convenga[n], y conociendo yo que las hay tanto mayores en este rey cuanto [son] mayores que [en] todos los otros reyes; y viendo juntamente la benignidad de su espíritu y condición, que, siendo él tan grande y poderoso señor y sin alguna necesidad de cosa o de persona alguna, él mire a la bajeza mía y por su gracia me quiera admitir a gozar de sus reales dotes y riquezas, cosas para enamorar al desamor y para hacer enternecer la misma dureza. Unido yo pues esto ${ }^{83}$, no puedo estar [tai] que vehementísimamente no le ame, le adore y le desee; antes, poniendo en él toda mi afición, andaré siempre embriagada en su amor, fuera de mí totalmente, por estar del todo y vivir en él. Y, de la misma manera [que], cuando los que han bebido algún buen vino en tanta copia que le[s] ha hecho de sus sentimientos estos tales, ninguna cosa hablan de sí mismos, ni movidos por su natural imaginación, sino todo lo dicen y

\footnotetext{
${ }^{73}$ Asiéndome: la forma que encontramos en el mantiscrito es aziendome.

${ }^{74}$ (De): suprimimos la preposición porque, según los usos actuales, se trata de un verbo transitivo, no necesitado de ella.

${ }^{75}$ Porque: valor final.

${ }^{76}$ Priesa: prisa.

${ }^{77}$ Corriades... andábades: formas arcaicas de pretérito imperfecto de indicativo.

${ }^{78}$ En el manuscrito, Gálatas (2). Concretamente, se trata de Gálatas (2, 14). Cristiana: en el manuscrito, xpiana.

${ }^{79}$ Retrete: Cuarto pequeño en la casa o habitación, destinado para retirarse (DRAE, 1). Término ya desusado en esta acepcion.

${ }^{80}$ Encitar: incitar

${ }^{81}$ Porque: valor final.

${ }^{82}$ Por esto: retoma la construcción comenzada cuatro lineas arriba

${ }^{83}$ Unido... esto: violento hipérbaton. Se trata de una construcción participial absoluta.
} 
trazan conforme a los espiritus de aquel sabroso y generoso vino ${ }^{84}$ que sobre su sentido reina; $\mathrm{asi}^{85}$ andaré yo siempre regocijada, diciendo y cantando o pregonando y publicando tus amores más dulces que toda la dulzura y más suaves y gustosos que toda la suavidad, de manera que los que vivir desean conforme a la virtud, viendo el regocijo y contento ${ }^{86}$ que en mi pecho se encierra[n] por las miestras que mi lengua y mis hechos darán, todos vendrán a amarte, deseando ser participantes de amores, que tanto contento dan al que los goza".

Dos lugares sacamos de este decir de la Esposa, que manifiesta la grandeza y begninidad de Dios. [El primero lo constituyen] la belleza y grandes riquezas que le mostró, por donde [se ve] esforzado ${ }^{87}$ el ánimo a amarle y desear[le]; más ${ }^{88}$, porque sería desatino tener uno su afición en casa que no espera de alcanzar, por la alteza o por la esquividad de ella; porque, como uno bien dijo, cuando el amor nació, nació esperanza, por eso dice la Esposa: "Metióme el rey". Y este es el segundo lugar que notamos ${ }^{89}$. Cosa es, cierto, de grande admiración y para encender un corazón. $\mathrm{O}$ [se] lee: "Lo que él mismo muestra, que me quiere bien y se precia de mi amor y se ofrece a él de su voluntad y, acetando el mío y aun deseándolo, me meta en sus retretes, mostrándome con cuánta razón le debo amar". Y de esta suavidad de condición de Dios, maravillado, el profeta decía exclamando: ¿Quién hay como el Señor Dios mío, que vive en las alturas y, con todo eso, pone sus ojos en las cosas humildes y bajas que en el cielo y en la tierra se hallan? $?^{90}$

\section{Negra soy, mas hermosa, hijas de Jerusalén.}

Esta Esposa de Cristo quiere decir la fertilidad y obediente Iglesia. Tan fea y abominable es a los ojos del mundo por la humildad y sufrimientos de persecuciones de cruz y injurias, por el desprecio de sí misma y por todas las otras cosas que en la exterior apariencia muestra, $\mathrm{y}^{91}$, por el contrario la Esposa $\operatorname{ser}^{92}$ [la] enamorada que es. La vana y regalada y ambiciosa soberbia es $\tan$ hermosa, tan delicada y tan galana y tan llena de regalos que enamora y $\operatorname{trae}^{93}$ a sí tardos los ojos y voluntades del mundo, de donde viene muchas veces [poner] en duda a los hombres cuál de estas dos $\operatorname{ser}^{94}$ la Esposa de Cristo y aquella de quien está tan enamorado; porque, siendo Dios tan hermoso, tan rico y sabio, no es posible que él escoja lo peor para enamorarse

\footnotetext{
${ }^{84}$ Vino generoso: el más fuerte y añejo que el vino comin (DRAE).

${ }^{85}$ Asi: retoma la construcción comenzada cinco lineas más arriba ( $Y$, de la misma manera...).

${ }^{86}$ Contento: alegria, satisfacción (DRAE, 3)

${ }^{87}$ Esforzar: dar o comunicar fuerza o vigor(DRAE, 1). Este verbo se utiliza más habitualmente en sentido reflexivo.

${ }^{88}$ Más además

${ }^{89}$ Notar: señalar una cosa para que se conozca o se advieria (DRAE, 1).

${ }^{90}$ Alusión biblica sin anotación al margen en el manuscrito. Salmo 113 (112). Titulacio Al Dios excelso y benigno.

${ }^{91} Y$ : equivalente a pero.

${ }^{92}$ Ser encontramos en esta oración una construcción sintáctica oscura. Probablemente se volucione parte del problema entendiend aqui es en lugar de ser

${ }^{93}$ Trae: atrae.

${ }^{94}$ Cuál... ser: interrogativa indirecta cunstruida con infinitivo. Lo normal en español actual seria aqui el presente de subjuntivo.
} 
de ello, ni siquiera regocijarse con la tristeza ni honrarse con la bajura ni preciarse de abatimiento ni tampoco mirar la fealdad. Y esto entiendo: las hijas de Jerusalén, que son algunos de los del pueblo de Dios, están [tan] maravillados ${ }^{95}$ que no osan responder al que este argumento les hace; se espantan después que con todo eso la Esposa se glorie de que el Esposo comunique sus secretos placeres y $\mathrm{la}^{96}$ haga particiones de sus riquezas. Por lo cual, ella, ocupándole[s] [la] pregunta que ellos ${ }^{97}$ le podrían hacer, les dice: "Hijas de Jerusalén, negra soy, mas hermosa. Sabed que hay dos maneras de belleza: una verdadera y otra falsa; una que es y otra que se muestra; una $\sin$ afeites ${ }^{98}$ y aposturas artificiales y otra sofistica de albayades ${ }^{91 "}$.

$\mathrm{Y}$, así, también hay dos maneras de ojos que estas bellezas contemplan: los unos son de corta vista, que fácilmente con cualquier claridad o luz o calor se encandilan; los otros son de lince, prespicacísimos ${ }^{106}$, que penetran sus rayos hasta las entrañas de todas las cosas. Y estos ojos postreros no se pagan ${ }^{101}$ de la hermosura cuyo fundamento son vanos y exteriores âeites, que la tal belleza no es [sino] fealdad, suciedad y bruteza ${ }^{102}$ grande que los mismos de esta belleza se arrean ${ }^{103}$. Cuando están a sus solas ${ }^{104}$ mirándose a la presencia de sus espejos 0 cuando se miran desnudos, quitado aquel lujo y máscara con que se muestran a los otros, [están] ellos con tanta vergüenza de sí que no querrían tener ojos con que verse. Esta belleza es de la Esposa (del) ${ }^{105}$ que solamente de ${ }^{106}$ las pompas, soberbias, honras y vanidades de fuera vestida y arreada encandila aquellos ojos cuya vista en la verdad de las cosas no puede penetrar. Los ojos de Dios, que son los que penetran hasta el centro de todas las cosas, no le enamoran sino de la otra belleza verdadera, que es la belleza interior del ánima, la cual consiste en tener bien informada ${ }^{107}$ la conciencia, bien aficionada la voluntad, y [en] que todo esto esté blanco, todo limpio y todo sencillo, sin manchar de vicio, ni afeite de hipocresía: esta belleza y hermosura contenta a los ojos de este gran enamorado y a los ojos también de quien la tiene.

\footnotetext{
${ }^{95}$ Están [tan] maravillados: deberia ir en femenino, pues su sujeto es las hijas de Jerusalén. Aparece sin embargo en masculino por ser e! género del sujeto de la oración de relativo incrustada.

${ }^{96} \mathrm{La}$ : caso de laísmo. No es muy frecuente. No creemos necesario señaiar cada aparición.

${ }^{97}$ Elios: aparece en masculino -igual que, más arriba, maraviliados- porque se trata de algunos de los del pueblo de Dios. Su referente en el texto, no obstante, es femenino: las hijas de Jerusalén.

${ }^{98}$ Afeite: cosmético. Palabra desusada. Afeitar: Adornar, componer, hermosear (DRAE). Palabra desusada en esta accpción.

${ }^{99}$ Albayade: aparece esta forma en lugar de albayalde: carbonato básico de ploms. Es sólido, de color blanco y se emplea en la pintura (DRAE)

${ }^{100}$ Prespicaz: por perspicaz.

${ }^{101}$ Pagar (prnl.): prendarse, aficionarse (DRAE, 5)

${ }^{102}$ Bruteza: brutalidad.

${ }^{103}$ Arrear (2): poner arreos, adornar, hermosear, engalanar (DRAE)

${ }^{104}$ A sus solas: modernamente, a soias.

${ }^{105}$ (Del): creemos conveniente la supresión para dotar de sentido a ıa oración.

${ }^{106}$ De: por

${ }^{107}$ Informar: formar, perfeccionar a uno por medio de la instrucción y buena crianza (DRAE, 2). Acepción desusada.
} 
Que, cuando una ánima [que] se mira está muy contenta, no se igualan todos los contentos del mundu con el suyo; pesares son todos los placeres de la tierra en comparación de ${ }^{108}$ la alegría que ella recibe.

Tiene la Esposa del mundo gran temor [de] que, si la viesen desnuda y sin aqueilos afeites, todos la aborrecerían, todos huirian y la blasfemarian; y, así, desea que todos sean ciegos y de otra vista, porque su intento es engañarlos y robarlos ${ }^{109}$ como ramera. Tiene, por el contrario, la Esposa de Dios gran certidumbre [de] que, si la viesen de dentro ${ }^{1.0}$ desnuda y a la clara ${ }^{11}$, todos la amarían, seguirían y alabarían; y por eso procura y desea abrir los ojos a todos, porque su próposito es desengañarlos para enriquecerlos con sus riquezas, como verdaderamente amante. Así que dice la Esposa: "Negra soy, mas de fuera a los ojos del mundo, que sigue solamente a la máscara del exterior parecer; mas hermosa por de dentro a los ojos de mi Esposo, que sabe bien escuger las bellezas". Y propone para declarar esto dos apropiadísimas semejanzas, diciendo en esta manera:

Como las tiendas de Quedar y las tiendas de Salomón.

Fue Quedar nieto de Abraham, hijo segundo de Ismael ${ }^{112}$, como se ve en el Génesis ${ }^{113}$. Los descendientes de este fueron todos pastores ricos que andaban en el campo sin tener ciudades ni moradas firmes, sino mudando cada tiempo su habitación ${ }^{114}$ siguiendo nuevos pastos, como se nota en Isaias ${ }^{115}$ en diversos lugares. [A] estos llamaron los antiguos Mímidos ${ }^{116}$, y nosotros llamamos ałıra Alarbes ${ }^{117}$. En la Sagrada Escritura es $\mathrm{mu}$, asado llamar a la nación el nombre de su origen, como a los gentiles Edom ${ }^{118}$ y a los judíos Israel; así también a estos llaman Quedar. La habitación de estos es en tiendas movedizas que se arman como las otras de la guerra, y estas scn muy capaces para encerrar toda su familia y alhajas. Como estos son ricos por el ganado y trato que tienen con otras naciones, tienen sus tiendas por de dentro muy proveídas de lo necesario y muy adornadas, y por defuera están muy negras por estar puestas al aire, sol, agua y polvo.

Hace, pues, semejante la Esposa su hermosura a estas tiendas, diciendo: "Por defuera os parezco negra, mas por de dentro soy bellísima y en esto parezco a las tieridas de los Alarbes y

\footnotetext{
${ }^{108}$ En comparación de: acutalmente, en comparación con.

${ }^{109}$ Robar: atraer con eficacia y como violentamente el afecto o ánimo (DRAE, 8).

${ }^{110}$ De dentro: actualmente, por deniro.

III A la clara: manifiesta, puiblicamente (DKAE)

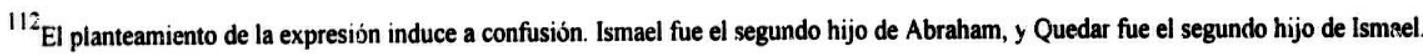

${ }^{113}$ En el manuscrito. Génesis (21). Nuevo error; se trata de Génesis (25, 12-14).

${ }^{114}$ Habitación: lugar ò casa donde se mora ì vive (Dic. Aut)

${ }^{115}$ En el manuscrito, Isaias ( 43 y 60 ). A lo largo de estos dos capítulos se recogen las informaciones que aqui su desarrollan.

${ }^{116}$ Mimidos: Numidas

${ }^{117}$ Alarbes: árabes.

${ }^{118}$ Edom: en el manuscrito aparecen las formas Edom y Ebdon.
} 
a las cortinas de Salomón, las cuales están en el templo que él fabricó, que ${ }^{114}$, interpuestas entre la vista del pueblo y el sanctasantórum ${ }^{120}$, no dejan ver las riquezas que allá dentro hay". Con esta declaración del vocablo Quedar se entienden muchos iugares de los Sagrados Libros. $\mathrm{Y}$ esta doctrina que aquí hemos ${ }^{121}$ notado de las dos hermosuras y de las dos vistas que la consideran esta graciosarnente tratada en la profecía de Malaquías ${ }^{122}, y^{123}$, por la brevedad que prometimos, no se tratara aquí el lugar.

No me miréis, que soy morena, porque me miró el sol. Los hijos de mi madre arremetieron contra mi y pusiéronme a guardar las viñas y la viña mia no guardé.

Por mostrar la Esposa que de suyo ${ }^{124}$ es hermosísima y que si por defuera parece estar algo tostada es por accidente y no por natural cualidad, dice: "Sabed, señores, que así como en lo de dentro, que está escondido a vuestros ojos, soy bella, asi en lo de fuera de mi propio natural lo soy". Que, andando las cosas por el camino de su deber, aquellas que más hermosas son de dentro y más agradan a Dios y de quien él más se enamora deberían en más ser tenidas del mundo, más bien tratados $y$ amados ${ }^{125}$. Mas, habiendo Satanás puesto en el mundo su bando contra Dios y siendo grande el número de los que lo siguen a él y a la soberbia vanidad su Esposa, de fuerza ${ }^{126}$ es que los pocos, siendo contrarios de los muchos, sin opinión ni bando padezcan de ellos principalmente, que así lo promete su capitán, Dios, por dar mayor premio a los que hubieren peleado por él y hacer mayor venganza en los rebeldes enemigos ${ }^{127}$.

[Dice pues la Esposa]: "Así que sabed, hermanas, que, si yo estuviera sosegada en mi casa y reposo, [sería] regalada, blanca y bella por defuera a la vista así como lo soy a la consideración por de dentro. Mas, andando como ando siempre al sol como las labradorcicas que trabajan por el campo, es de fuerza que yo me haya de tostar y tornar morena. Y, porque no penséis que sea mi culpa esto, por quererme yo andar fuera de casa a espaciarme al sol, sabed que los hijos de mi madre, mis hermanos, que son los doctores y sabios de mi ley, las cabectras de mi religión, me sacaron de la guardada viña, que es la verdadera religión, la cual Dios me había entregado y encomendado, y me hicieron que guardase sus viñas de ellos, porque ellos han querido plantar diversas viñas y majuelos ${ }^{128}$ para sí, no queriendo trabajar en esta viña de Dios; y de

\footnotetext{
${ }^{119}$ Que: la yuxtaposición puede inducir a confusión. Esta proposición de relativo depende, como la anterior, de cortinas.

${ }^{120}$ Sanctasantórum: parte interior y más sagrada del tabernáculo erigido en el desierto, y del templo de Jerusalén, separada del santa por un velo (DRAE, 1)

${ }^{12 i}$ Hemos para la formación del pretérito perfecto de indicativo, se utiliza casi exclusivamente esta forma, apareciendo sólo una vez la forma habemos.

${ }^{122}$ En el manuscrito, Maiaquias (3)

${ }^{123} Y$ : posee un sentido más adeversativo que copulativo.

${ }^{124}$ De suyo: naturalmente, propiamente o sin sugestión ni ayuda ajena (DRAE).

${ }^{125}$ Tratados y amados: se rompe la concordancia. Deberian aparecer en femenino, pues de dependen de cosas.

${ }^{12 f}$ De fuerza: por fuerza.

${ }^{127}$ La idea aqui recogida pertenece, comc señala marginalmente el manuscrito, a Salmo 149. En este caso, no hay ya doble numeración en el Salmo, puesto que se ha producido una nueva refundición (entre los Salmos 146 y 147). El título de este Salmo es Kimno del pueblo a Dios.

${ }^{128}$ Majuelo: viña.
} 
alli ser pagados y llevar su parte al tiempo de la cosecha. Antes, por sus particular us intereses, se han andadc plantando diversos majuelos y viñas para si, unos movidos por ambición, otros por avaricia, y por estos diversos respectos induciendo ${ }^{129}$ en la religión cristiana diversas idolatrías y leyes y estatutos causa de grandes pecados y ofensas de Dios ${ }^{130}$. Es para colozear y asegurar sus negocios [para lo que] me ponían a mí por guarda, pretendiendo religión y buen celo; $y$, porque ${ }^{131}$ no me pudiese escapar ni huir, arremetieron conmigo y me tuvieron ${ }^{132}$ a guardar sus viñas, por lo cual soy forzada a estar así tostada por defuera, pareciendo morena a quien no mira que los buenos, no queriendo seguir el camino del apetito de los malos, son forzados a padecer trabajos y persecuciones, huidas ce tierras, afrentas y muertes; y otros callan y disimulan, llorando entre si por ver sembrada ia sagrada religión de tantas cizañas y malas simientes, no pudiéndolo ellos remediar".

Y, así, esta bellísima doncella, Esposa de Dios, viene a parecer morena y tostada a los ojos del mundo; por eso se queja ella, diciendo: "Los hijos de mi madre arremetieron conmigo y pusiéronme a guardar sus viñas, y la mi viña no guardé yo porque no me consentían ellos entrar en mi viña (quiere decir "en mi pura, generosa y sencilla religión, ley y fe"), sino mezclaban sus humanos estatutos, que no iban conformes a la Divina Doctrina, como se lo reprende mi Esposo, diciéndoles `por los estatutos y ordenanzas de vuestros padres, despreciáis los mandamientos de Dios ${ }^{\prime 33}$. Y, así, yo estaba muy fatigada y descontenta por verme hecha viñadera ajena, y que ${ }^{134}$ la mi viña quedaba sin guarda". Y, en decir en este lugar arremetieron conmigo, se entiende todo impetu y fuerza que los malos hacen a su fiel Iglesia y a sus miembros. Y, donde dice viña mía, en lo hebreo tiene doblada fuerza, que dice mía remia, dando a entender cuán suya propia es y cuánto cuidado debe tener de ella(s) ${ }^{135}$, y que esta viña sea la religión de Dios, la cual él plantó primero en tierra de los hebreos y después traspasó en los gentiles. En muchos lugares de las Sagradas Letras se manifiesta, porque Isaías y Jeremías $^{136}$ dan clara noticia de ello en su Evangelio ${ }^{137}$.

Hazme saber tú, a quien mi alma ama, dónde apacientas, donde huelgas al mediodía. ¿Por qué andaré yo rebozada por las manadas de tus compañeros?

El que verdaderamente ama no reposa jamás ni mira en los puntillos y cumplimientos que se usan entre los que se tienen poco amor y caridad. Si yo bien amo a una persona y veo que

${ }^{129}$ Inducir: ocasionar, causar (DRAE, 2). Acepción desusada

${ }^{130}$ Pecados y ofensas de Dios: construcción semejante a la latina llamada de genitivo objetivo.

${ }^{131}$ Porque: claro sentido final

${ }^{132}$ Tener: en el sentido de retener, próximo al latin teneo

${ }^{133}$ Esta idea se recoge, como señala el manuscrito en anotación marginal, en San Mateo (15). Concretamente, se trata de San Mateo (15, 1-3).

${ }^{134}$ Verme... y que: el infinitivo ver lleva dos complementos directos coordinados, que son el pronombre enclirico (me) la completiva introducida por que.

${ }^{135}$ Ella(s): fallo en la concordancia. Deberia ir en singular, referido a viña.

${ }^{136}$ Jeremias: la forma habitual con que encoritramos esta palabra en el manuscrito es Hieremias.

${ }^{137}$ Evidentemente, se trata de un error; Isaias y Jeremias no fueron Evangelistas. El hecho de que aparezca aqui la inención del Evangelio se debe a que esta cuestión se halla recogida también en ese lugar. Asi se puede apreciar, además, en la nota marginai del texto, que es la siguiente: Isaias (5); Jeremias (2); San Mateo (20 y 21). 
no viene a mí, no ine quita ningún respeto que yo le vaya a buscar; no espero que use conmigo $(\text { de })^{138}$ crianza ${ }^{139}$ para usarla yo con él finalmente. Entre los que se aman, aquel se tiene por más honrado que ${ }^{140}$ más trabaja y más puede por el otro. Así, la Esposa, amando con grande fervor a su Esposo y habiendo deseado su venida, como arriba hemos dicho, no cabe en sí si puede sufrir su ausencia, y por eso en todas maneras lo quiere buscar y antes que salga ella le ruega que le haga saber dónde le hallará.

Cierto, palabras son estas que representan grande amor. No puede la Esposa reposar de ${ }^{141}$ no ir a buscar a su Esposo, y va tan aficionada que en todo el camino no quiere encontrar a otra persona, porque cualquiera cosa que el amante encuentre fuera de lo que ama le da gran pena y le mueve a dolor del corazón y le parece que nunca ha de hallar a su amado, como vemos en una madre que espera a su hijo alejado de su presencia: que ve venir de fuera a otro hijo de su vecina [y] luego llora por el suyo; en oyendo que traen cartas de otro, comenta su desgracia, porque no querría ver cosa sino del que ella desea.

Así que la Esposa pide a su amado le avise [de] dónde le hallará cierto, porque no querría encontrar[se] con otra persona, así por la pena que recibe como porque querría ella guardársele muy pura y sin ningún estropiezo ${ }^{142} \mathrm{ni}$ achaque de su fama. que es una de las mayores partes de dote que una Esposa lleva a casa de su Esposo. Y, porque andar una doncella por diversas partes siempre da que pensar mal y decir, no querría la Esposa andar de una cabaña en oira preguntando por su Esposo, porque, como hemos dicho, es peligroso en las doncellas el tal vaguear. Dice pues: "Hazme saber, amor de mi alma, dónde apacientas tu ganado, adonde ${ }^{143}$ lo haces reposar al mediodía". Es el Esposo pastor, como ya arriba hemos dicho, y por eso siempre lo han de hallar con sus ovejas, que nunca se aparta el buen pastor de su ganado, como el mismo Esposo lo dijc, hasta poner ${ }^{144}$ la vida por él si es menester. Este pasto es ia Doctrina Sagrada, que, gustada ${ }^{145}$, [da] la vida a los que de ella se mantienen; y, así, apacentar significa "hartar las ánimas de esta palabra de vida", y en esta significación lo traen los profetas y evangelistas en muchas partes; $y$, desque ${ }^{146}$ el ganado está harto de esta doctrina, se sigue luego la huelga ${ }^{147} \mathrm{y}$ reposo, en medio [de] las tribulaciones y calores y desasosiegos del mundo, entre los cuales los bien apacentados en esta doctrina de Dios están tan en su reposo, como los

\footnotetext{
${ }^{138}$ Use... (de): surprimimos la preposición porque, según los usos actuales, se trata de un verbo transitivo, no necesitado de ella.

${ }^{139}$ Crianza: urbanidad, atención, cortesia (DRAE, 3).

${ }^{140}$ Aquel... que resulta más :sual en castellano actual, en oraciones como esta, colocar el antecedente más cerca del relativo, casi siempre innediatamente antes. Puede tratarse aqui de un influencia del modo de construcción latina.

${ }^{141}$ Reposar de: construcción preposicional inusual actualmente $;$ cierta diferencia en el uso del verbo respecto al actual.

${ }^{142}$ Estropiezo: tropiezo.

${ }^{143}$ Adonde: donde.

${ }^{144}$ Poner: exponer.

${ }^{145}$ Gustada: construcción de participio absoluto

${ }^{146}$ Desque: Desde que, luego que, asi que (DRAE). Forma ya desudada.

${ }^{147}$ Huelga: recreación que ordinariamente se tiene en el campo o en un sitio ameno (DRAE, 5)
} 
ganados en sus acareos ${ }^{148}$ y siesta al mediodía, como lo promete Dios en el salmo, cantado por su profeta: El sol no te quemará al mediodia, ni la luna te fatigará de noche $e^{149}$.

"Muéstrame pues, ¡oh dulcísimo Esposo! -dice la Esposa- dónde te hallaré apacentando tu ganado o recreándolo o defendiéndolo del mediodía; porque hay muchos que andan apacentando ganados, mas son pastores alquiladizos ${ }^{150}$, gente perdida y que trac su ganado perdido, ciegos y guiadores de ciegos, y con todo eso se quieren poner en competencia contigo llamándose tus compañeros no siéndolo; $y$, si les pregunto por ti, cada uno me dirá 'aquí está', 'por allí fue', 'por acullá ${ }^{151}$ anda'; y has tú avisado a los que te procuran que no me crean, a los mentirosos indicios de los cuales dan malas nuevas y malas de ti. Por tanto, avísame, Esposo, de tus pastos verdaderos y de tu santísima doctrina porque ${ }^{152}$ no ande yo triste y fe gada buscándote por las doctrinas vanas de los gentiles dioses, los cuales traen perdido su ganado por las tradiciones de las engañosas discusiones humanas sin divino fundamento".

Esto postrero habla la Esposa con afección, apasionadamente preguntando así: ¿Por qué tengo yo de $e^{153}$ andar cubierta entre las manadas de tus compañeros?. Antiguamente, costumbre fue que las viudas salían de sus casas cubiertas los rostros ${ }^{154}$, arrebozadas ${ }^{155}$ por dar a entender luto y honestidad, de manera que era señal de tristeza el andar rebozadas. También las mujeres públicas no salían fuera sin rebozo, como se lee en Tamar. Iunque alguna diferencia había entre el rebozo de las unas y de las otras, a ambos sentidos puede encaminar[se] esta queja. Que la Esposa, o que diga: "¿Por qué consentirás tú, joh Esposo mío!, que yo ande buscándote triste y afligida, cubierta como las viudas y aquellas que han perdido lo que amaban?"; o: "¿Por qué tengo yo de andar de hato en hato preguntando por ti a los pastores que allí estarán ${ }^{156}$, cosa que no me parecerál ${ }^{157}$ bien y me tendrán por una de las arrebozadas? Quiero decir que ando en peligro -andándote buscando por las doctrinas ajenasde perder la simplicidad y limpieza que tú quieres que haya en mí". Y este sentido conforma con la letra hebrea.

Si no te sabes, joh bellisima entre las mujeres!, sal de tu moraaia y sigue las pisadas de las ovejas y apacienta tus cabritos junto a la majada de los pastores.

${ }^{148}$ Acarear: hacer cara, arrostrar (DRAE, 2)

${ }^{149}$ En el manuscrito, Salmo 120 (121). El titulo de este Salmo es Dios, centinela de su pueblo.

${ }^{150}$ Alquiladizo: del verbo alquilar, tiene sentido despectivo referido a personas.

${ }^{151}$ Acullá: a la parte opuesta del que habla (DRAE). Forma de claro sabor arcaico.

${ }^{152}$ Porque: sentido final.

${ }^{153}$ Tengo... de: perifrasis de obligación anticuada, paralela a haber de, usada actualmente.

${ }^{154}$ Cubiertas los rostros: podria pensarse, en principio, que este sintagma fuera una construcción participal absoluta. En dicho caso, deberia ir entre comas y habria un fallo de concordancia. Creernos, sin embargo, que se trata de una construcción paralela a la denominada en sintaxis latina "acusativo de relación", y que por esto no se da la concordancia.

${ }^{155}$ Arrebozar: rebozar

${ }^{156}$ Estarán: uso del futuro en lugar del presente de subjuntivo, más lisual actualmente en construcciones de este tipo.

${ }^{157}$ No me parecerá bien: léase no me hará parecer bien. 
Prestísimo es el Esposo a las voces de la Esposa. No puede sufrir un corazón generoso que quien le ama pene mucho por él. Y, por eso, entendiendo que su Esposa lo desea y querría hallar, es muy presto en alumbrarle el camino. Le dice pues: "Si no te sabes, joh bellisima Esposa!, donde esté, darte he ${ }^{158}$ modo con que me halles sin errarme, y es que salgas de tu casa donde estás holgándote y recojas tus cabritos delante para llevarlos a pacer, porque no está bien que, siendo yo pastor, tú que eres mi Esposa huelgues: apacienta también tus cabritos. Del ganado mayor yo tengo cuidado y los pastores, que son mi compañía verdadera; tú apacienta tus cabritos, los que son flacos, que no han llegado aún a aquella periección que tienen los fuertes en la fe. Y así me hallarás si tú sales al campo; y, demás ${ }^{159}$ de esto, irás más sin recelo de ser tenida por vagamunda ${ }^{160}$, porque, viéndote que andas entendiendo en guardar ganado menudo, nadie terná ${ }^{\mid 61}$ qué decir de ti, como quiera que entenderán que eres esposa de algún pastor cuyos cabritos tú gobiernas, andando él con las cabezas mayores. Y, porque para caminar adonde estoy no te estorbe alguna ignorancia, nunca vayas por los lugares que no están hollados ${ }^{162}$, sino por donde vieres que han andado ovejas, que son los tus antepasados justos y estos que fueron ovejas del rebaño de Dios, y estas te darán a entender con sus huellas dónde están los verdaderos pastores; porque, siguiendo tú [a] los que verdaderamente fueron buenos, entenderás cuál es el buen pastor y, por la huelia de aquel ganado, hallarás las cabañas de los pastores buenos, que son los que enseñaron y apacentaron de este celestial manjar de la verdadera y sana doctrina, cuales fueron Moisés ${ }^{163}$, David, Isaías y los demás, cuyas moradas y cabañas son muy fáciles de hallar a quien sigue las pisadas de las ovejas que ellos apacentaron", entre las cuales el Esposo avisa que sin duda le hallarán. Y de esto tienen los buenos pastores promesa del mismo Esposo, cuando, encargándoles el Evangelio, dijo: "Tened por cierto que yo estoy entre vosotros hasta el fin del siglo ${ }^{164 "}$. "Pues [-continúa el Esposo-], viniendo tú, Esposa mía, en rastro de las ovejas, acertarás muy bien dónde yo estoy y, demás ${ }^{165}$ de esto, los cabritos irán más a su placer y seguros viendo rastro de otro ganado mayor".

Vengamos ahora a declarar la letra. Si no te sabes: El te abunda por propiedad de la lengua, como en la nuestra también decimos "no sabes lo que te dices". Bellisima entre las mujeres: Todas las Iglesias de los gentiles, sinagogas y compañías de las otras sectas se llaman aquí mujeres, entre las cuales la Esposa de Cristo es bellísima. Salte -el te abunda como arriba está dicho- [y] apacienta tus cabritos: Porque ordinariamente a las mujeres, por ser más delicadas, no las ponen en recios trabajos. Si el marido cava, ella quita las piedras; $y$, así, si el marido trae el ganado mayor, ella suele andar con el menor.

\footnotetext{
${ }^{158}$ Darte he: en la fonna de infinitivo seguido del auxiliar haber, como en este caso, está el germen de lo que vendrá a ser el futuro romance. Puede verse claramente en nota 334

${ }^{159}$ Demás además

${ }^{160}$ Vagamunda: vagabunda. Se irata del fenómeno denominado etimologia popular

${ }^{161}$ Terná: forma arcaica de futuro imperfecto

${ }^{162}$ Hollados: pisados

${ }^{163}$ Motsés: en el manuscrito aparecen las formas Moysem y Moisen.

${ }^{164}$ Siglo: mucho o muy largo tiempo, indeterminadamente (DRAE, 3).

${ }^{165}$ Demás además.
} 
A la caballería mía en los carros de Faraón te asemejé, amiga mía.

Comienza ya el Esposo a usar de sus regalos con su Esposa. Se muestran y se avisan mucho los amores con los trocados razonamientos y requiebros, y es muy común y muy gustoso entre los que bien se quieren apcdarse unos a ctros; y más dulces comparaciones y semejanzas se ponen mientras más se aman. Alabó, pues, a la Esposa apodándola a la caballería suya en los carros de Faraón. Y, porque la letra está revuelta, desmarañémosla primero y luego iremos al sentido. Tanto quiere decir este texto como dijese: "A una de las yeguas de Egipto que anda en mis carros te asemejé, joh amiga mía!" Noticia tenemos en la divina república [de] que los caballos de Egipto son muy generosos en ligereza, cono se ve en el Segundo Libro de los Reyes $^{166}$ y en el Paralipómenos ${ }^{167}{ }^{168}$, donde se cuenta que traían de Egipto gran número de caballos castizos y que con ellos armaban carros. Los reyes de Egipto antiguamente se llamaban faraones, y era nombre común a todos ellos, que significaba "vengador" 0 "restituidor", porque los antiguos acostumbraban [a] poner nombre a las dignidades de los oficios que los maestros de ellas tenían. Así como los romanos llamaban cónsules a los que tenían cargo de aconsejar y consultar ${ }^{169}$ las cosas de la república, así los Egipcios llamaban a sus reyes faraones, porque tenían por oficio (de) ${ }^{170}$ castigar lo malo y amparar lo bueno. Y esto parece que quiso [decir] Jatar, faraóin, a José ${ }^{171}$, diciéndole: Yo soy Faraón ${ }^{172}$. Y es costumbre en la Sagrada Escritura liamar a las provincias por los nombres de sus principales, como también lo usan los libros de las otras lenguas.

Pues tanto quiere decir como si dijera: "Cuanto es bella una escogida yegua de Egipto que, puesta en mi carro, lo lleva ligero y galanamente, tanto eres tú ligera, bella y bien compuesta para llevar el suave yugo de la ley y doctrina mía y correr aprovechando mucho en ella". Porque el yugo donde se juncen ${ }^{173}$ los caballos o bueyes para lievar el carro significa la doctrina y ley a que el alma va atada corriendo por la carrera de esta vida, y el carro con que se tira y lleva la carga significa lo mismo, como lo declaró Cristo cuando dijo: "Mi yugo es suave y mi carga liviana".

Bellas son tus mejillas con sus ornamentos y tu cuello con sus collares. Joyas de oro te haremos con remates de plata.

\footnotetext{
${ }^{165}$ En el manuscrito, il Reyes $(10,3)$.

${ }^{167}$ Paralipómenos: en el manuscrito, Paraliponemon.

${ }^{168}$ Los Paralipómenos son dos libros que la tradición ha considerado como continuación del Libro de Samuel y de los dos Libros de los Reyes. Sin embargo, en la actualidad se cree, por sus contenidos, que son una recopilación de estos libros. Modernamente se conocen como Libros de las Crónicas. No hay ninguna anotación en el manuscrito que concrete esta alusión. Se trata de II Paralipómenos (1,14-17).

${ }^{169}$ La palabra cónsul ha perdido su sentido etimológico. Se deriva del verbo latino consulo (que significa deliberar, consultar, decidir, castigar) y relaciona con palabras como consilium, que en espatiol ha dado consejo.

${ }^{170}$ (De): según los uso actuales, la construcción no requiere esta preposición, pues los ir. ‘nitivos a los que acompaña realizan la función de sujeto.

${ }^{171}$ José: en el manuscrito, Josef.

${ }^{172}$ En el manuscrito, Génesis (42)

${ }^{173}$ Juncir: Uncir, yungir, poner el yugo (DRAE).
} 
Prosigue sus loores el Esposo, alabando a la Esposa de belia, cosa muy conforme a lo que la Esposa arriba decía, que era hermosa, porque su Esposo bien entendia su hermosura y porque, como uno en su poesía dijo, un bello manto -o una bella ropa- adorna mucho. Dice el Esposo: "No solamente tú eres bella, mas ${ }^{174}$ no hay cosa que te pongas que no te adorne mucho y parezca nacida para servicio y ornamento de tu hermosura"; lo cual no suele acaecer a las feas, porque, mientras más ricamente se adorna[n], peor parecen. Por eso dice: "Bellas son tus mejiilas como las piedras puestas en orden"; esto es descripción de las arrecadas ${ }^{175}$ que las mujeres cuelgan de las orejas, en las cuales ponen piedras de valor engastadas en oro, de manera que hagan alguna figura graciosa, como lo vemos en nuestro tiempo. Y dice más: "Tu cuello con los collares es hermoso". El cuello y rostro del hombre, con sus principales partes, en cuya figura y apostura más se diferencian de las partes de los otros animales por ser de gentil composición y proporción de partes, y en los cuellos principalmente está la silla de la belleza exterior ${ }^{176}$; demás ${ }^{177}$ de esto, su natural postura es estar levantadas estas dos partes y hacia el cielo derechas, lo cual da a entender la dignidad de esta criatura; y, así, por estas partes entendemos la rectitud del entendimiento y voluntad humana[s] ${ }^{178}$, que son el rostro y cuello de nuestro ánimo. El uno mira a las cosas altas, el otro embebe y revuelve a ellas para amarlas y procurar[las].

Pucs, cuando estas dos partes están hermosas y bien adornadas con las palabras de la ley y doctrina de Dios, que en este lugar se entienden por las piedras y collares, viene el Esposo a loar mucho la tal hermosura como lindeza y beldad perfecta y digna [de] que él, con su amor, la sigue ${ }^{179}$ y se junte con ella para celebrar el santísimo matrimonio donde se haga uno con esta alindada Esposa, la cual es fin de estos divinos amores. Y, porque muestra haberle agradado esta hermosura, por eso la quiere mucho.

Le promete luego dones -conforme a lo que los otros esposos suelen hacer, dando a sus esposas joyas, galas, que son las cosas con que las mujeres más se huelgan- diciendo: Oro te daremos con remates de plata. En el hebreo, donde se dice joyas hay un vocablo que significa "tórtolas"; y está muy gracioso en este lugar aquel significado, porque es muy usado entre los enamorados, entre los servicios que hacen a sus amadas, darles algunas cosas que tengan símbolo y significación de sus afectos -unos de amor, otros de desesperación, otros de cuidados-, y algún motete ${ }^{180} \mathrm{o}$ letra que tenga el nombre de persona o de cosa que ellos quieren dar a entender, o poniendo figura o color alguna que dé a conocer lo que ellos sienten. Pues así

\footnotetext{
${ }^{174}$ Mas: equivalente a sino.

${ }^{175}$ Arrecada: aparece esta forma en lugar de arracada: arete con adorno colgante (DRAE)

${ }^{176}$ El cuello.. belleza exterior: la estructura sintáctica de esta oración resulta complicada, probablemente poi faltar alguna palabra o haber alguna grafia errónea. Encontramos dos posibles lecturas. En la primera, habriamos de soponer ura preposición en al principio de la oración De cste modo, el complemento circunstacial (En el cuello y rostro...j se coordinaria con el que aparece más abajo (y en los cuellos), habiendo, de este modo, un solo verbo en la proposición principal (está). Según la segunda interpretación, supondriamos un error en la grafia $c$ de coiı sus principales partes, entendiendo son. Asi, la conjunción coordinaria, no dos complementos circurstaciales, sino dos oraciones.

${ }^{177}$ Demás: además.

${ }^{178}$ Humana[s]: concuerda únicamente con el sustantivo más cercano de los dos a los que califica.

${ }^{179}$ Sigue: seria más normal un verbo en subjuitivo. Además, va precisamente coordinacio con otro verbo que sí va en este modo.

${ }^{180}$ Motete: apodo.
} 
promete el Esposo (de) ${ }^{181}$ dar a su Esposa los arracates ${ }^{182}$ de oro en forma de dos tortolicas y que tengan los remates, que es ${ }^{183}$ el pico y las unas de plata, porque lo uno al presente es hermoso y lo otro da a entender su afecto puesto en una persona sin amar a otra, y durable que no le puede corromper ningún accidente. Que, así como de las tórtolas se escribe que sólo dos, macho y hembra, vienen en este clarísimo amor y, en faltande el uno o el otro, su corazón le es leal hasta la muerte; así el Esposo y [la] Esposa hayan de ser uno en amor, y que él no ame como no amará a otra que a su fiel Esposa, y ella no debe (de) ${ }^{184}$ amar a ninguno fuera de su dulcísimo Esposo. Y, si queremos también declarar por qué las promete de esta materia -oro y plata-, diremos que estos dos metales, en la Sagrada Zscritura, son símbolos de la doctrina y fe pura, purgada, sencilla, según aquello de David: Las palabras del Señor puras, plata pasada por el fuego, apartada de la escoria, afinad $a^{185}$. [Otras] veces, el oro significa la claridad que [a] todas las injurias y aflicciones vence, como el oro se escapa de todas las cosas que son causa de corrupción. Así dijo David hablando del varón justo: Sus palabras de oro amarillo ${ }^{186}$. Y, de esta manera, el Esposo y la Esposa están muy firmes y conjuntos en el amor, habiendo en ella estas virtudes de fe pura y claridad que todo lo sufre.

Cuando el rey estaba reclinado a la mesa, el mi nardo dio su olor. Común cosa es a los apasionados en cualquier afecto que, cuancio tienen presente aquello que les mueve a su pasión o están cerca de ello, les parece que todas las cosas les dan indicio de ello; de esta manera, le traen a una persona una triste nueva. Luego dice: "El alma me lo daba todos estos días, porque, verdaderamente, cosa no había que no me moviese a tristeza". Otro, viendo a quien bien quiere delante de sí, o alguna buena nueva de él, dice que su corazón lo adivinaba por cierta alegría que, fuera de uso, en sí sentía.

Este afecto que hemos mostrado está en las palabras que ahora la Esposa dice, la cual, sintiendo la dulce y amorosa voz de su Esposo, que le decía que lo hallaría entre los pastores, conversando, andando y comiendo con ellos, y que no era muy lejos de donde ella estaba, dice: "Verdaderamente grande fuerza es la de la presencia de mi Esposo -o cercanía-, porque yo luego sienio en mí nueva alegría y nuevos movimientos; porque, ahora, estando sentado a la mesa con sus compañeros acá donde yo estoy, he sentido, no solamente en mí mas ${ }^{187}$ en todas mis cosas, grande y nuevo regocijo, tal que la bujeta ${ }^{188}$ del oloroso nardo que conmigo traigo aviva su olor como si fuera puesta al calor del sol o fuego. Gran fuerza tiene en mí este amor, pues las cosas exteriores a mi persona sienten alegría con la presencia de mi querido". Y, así,

\footnotetext{
${ }^{181}$ (De): suprimimos la preposición al resultar innecesaria según los usos actuales por ser prometer un verbo transitivo.

${ }^{182}$ Arrecates: variante de arracadas.

${ }^{183}$ Es: concuerda sólo con el primero de sus dos sujetos.

184 (De): suprimimos la preposición puesto que, en castellano actual, la perifrasis deber de + infinitivo tiene valor de probabilidad, nientras que deber + infinitivo implica obligación, pareciendo claro que es este segundo valor el que aparece en el texto.

${ }^{185}$ En el manuscrito, Salmo 11 (12). El título del Salmo es Las tramas de los malvados.

${ }^{186}$ En el manuscrito, Salmo 67 (68). El titulo del Salmo es Procesión triunfal con el arca.

${ }^{187}$ Mas: equivalente a sino.

${ }^{188}$ Bujeta: Pomo para perfumes que se solia traer en la faltriquera (DRAE)
} 
es la verdad que, estando presente o cercano Cristo a su Esposa, no solamente elia dentro de sí está contentísima y ferviente, mas ${ }^{189}$ en las cosas exteriores de sus palabras y obras siente muy gran suavidad de buen olor.

En ia letra hay dos vocablos que declarar: rey y reclinado. $\mathrm{O}$ reclinación porque dice "estando el rey en su reclinación" ${ }^{190}$. [En] cuanto al sentido literal, rey llama a su Esposo la Esposa conforme a la común habla de los que aman, que, aunque sean pastores -como aquí se fingen aquestos dos amantes-, no hay nombre de dignidad que no se pongan uno a otro, ni rey ni señor ni ángel; y esto causa el amor, que todos los bienes y prosperidades desea ver en el amado y se imagina. En él los hay para amarlo y preciarlo tanto y más que si de hecho los tuviese. [En] cuanto al sentido espiritual, rey significa Cristo, el cual es verdadero rey de todo el universo, heredero legítimo de su padre, como lo testifica Jeremías, diciendo: Reinar ha rey sabic $^{191}$, y otros muchos lugares de la Sagrada Escritura. El otro vocablo es hebreo, mececibo, y ue quiere decir "en su reclinación", y la declaración de él es "estando sentado o recostado a la mesa"; porque los hebreos solían comer sentados sobre sus sillas o escaños y acostados un poco sobre el brazo izquierdo, y, por eso, el vocablo "reclinación" significa lo mismo que "estar a la mesa sentado". Estando, pues, a la mesa este eterno rey con sus compañeros, los buenos pastores, comunicando el vivo mandar de su doctrina, luego la Esposa siente dulces y nuevos alientos y su bujeta deja vivo olor.

Envoltorio de mirra es el mi amado para mí, y entre mis pechos estará; racimos de cánfora el mi amado para mi en las viñas de Engadi.

Responde la bella Esposa a los loores que su Esposo de ella había publicado y a las semejanzas que él [había hecho] alabándola arriba en los requiebros, apodándola a una gentil y gala[na] yegua. Trae muy bien un carro, cosa bien conforme a las palabras de un mancebo del campo. Ahora ella se requiebra con él por semejanzas bien apuestas y convenientes a una doricella, que son algalias y otras cosas olorosas que ellas suelen mucho preciar. Dice pues: "Es mi amado Esposo un envoltorio de mirra que tiene suavísimo olor, y por eso lo quiero y lo precio tanto que entre mis pechos pienso siempre traerlo como cosa que mucho me agrada"; porque las cosas que amamos y estimamos suelen los hombres traer en el seno y las mujeres en los pechos para tenerlas más guardadas y juntas así y gozar más de ellas. Y así se entiende aquello de San Juan que dice: El unigénito que estaba en el seno del padre ${ }^{192}$; nos lo contó dándonos a entender cuán preciado, amado y regalado era el hijo de Dios de su padre. Dice que lo tenía en su seno, así que, si la Esposa apoda a su Esposo a un envoltorio de mirra, cosa muy preciada y olorosa antiguamente, de que ahora tenemos poca noticia, $(y)^{193}$ se ve sli precio en esto, que los Magos, viniendo a adorar al Rey nacido nuevamente, le traían mirra como don que sin vergüenza podrían presentar a un rey; y, en muchos lugares de la Sagrada Escritura, se hace mención de ella. Y, porque la mirra, según los que la describen, es especie de resina que

\footnotetext{
${ }^{189}$ Mas: equivalente a sino.

${ }^{190}$ O... reclinación: aqui esperariamos una segunda parte de la disyunción que se anuncia al principio de la oración.

${ }^{191}$ En el manuscrito, Jermias (23). Concretamente se irata dc Jeremias $(23,5)$.

${ }^{192}$ En el manuscrito, San Juan (1). Concretamente se trata de San Juan $(1,14)$.

${ }^{193}(Y)$ : suprimimos la preposición porque la oración que aqui comienza no va ccordinada con la anterior, sino que es la oración principal de la secuencia que con ella forma.
} 
viene a granas, el vocablo hebreo antes significa envoltorio que manojo; llamamos envoltorio cosa envuelta en paño.

El espíritu ${ }^{194}$ de esto es que la Esposa tiene por preciosísimo a su Esposo Dios y no le quiere apartar de sí; antes, para traerle más segura y que no se le pierda, le pone entre sus pechos abundantes de la Iglesia, de donde sale toda la doctrina con que se sustentan los hijos de ella; y, de esta manera, se conserva bien el amor divino entre estos dos pechos, que en cualquiera otra parte de la doctrina de los hombres [que] le quieran traer no le hallaremos cuando pensamos que le tenemos muy guardado.

Para más encarecer la Esposa este amor y estima en que tiene a su Esposo, repite la senîencia de arriba, diciendo: Racimo de cánfora es el mi amado a mi en las viñas de Engadi. Esto es como en la Divina Escritura, cuando [se] quiere mucho dar a entender una cosa, decirla por diversas maneras. Y, así, el sentido de aqueste lugar está entendido por el de arriba, que no hay que declarar salvo los vocablos cánfora ${ }^{195}$. En hebreo se llama copher, y es aquel racimo de donde se saca el bálsamo verdadero, el cual solamente en Palestina se halla. El árbol es a manera de vid, y los racimos son como de parra, y el lugar donde se cría [se] llama viña, porque en todo son muy semejantes. Y las más generosas plantas de este género eran las de Engadi, ciudad cercana de desierto y al mar muerto, como se lee en Josué ${ }^{196}$. Y, por esto, dice: "Racimo de copher en las viñas de Engadi, y del más precioso que en el mundo se hace". En la lengua hebrea hay un vocablo que significa esta planta, como ya hemos dicho, y no lo hay en latín ni en nuestra lengua, porque la planta es peregrina a nosotros. Y, por eso, lo declara[n] en diversas maneras: unos exponen "cipro", otros "cánfora", y un hebreo lo declara en arábigo en significación de "albena". Mas, sabiendo qué sea la cosa y cóıno se llana en la tierra donde la hay, poco va en saber como la puedan acá llamar.

¡Cómo eres hermosa, amiga mía, cómo eres hermosa y tus ojos de paloma!

Porque es común cosa de los que mucho se aman loarse y contender mucho en este oficio, torna el Esposo [a] loar a su Esposa, $10^{197}$ cual él conoce, ser sumamente bella fuera de lo que las hijas de Jerusalén pensaban. Y, así, con esta repetición usada en la Sagrada Escritura, como hemos dicho, declara su belleza ser grande, diciendo: Hermosa eres, amiga mía, hermosa eres, dando a entender que del todo sea hermosa. Y, porque gran parte de la hermosura y perfección está en los ojos, de tal arte que, aunque sea bien dispuesta y de bellas facciones una persona, si tiene los ojos feos todo se desdora, siendo los ojos instrumento del más precioso sentido del hombre y unas ventanas por donde los afectos del ánima más claro se muestran; por eso ${ }^{198}$ particularmente, después de haber testificado la tal beileza de su Esposa, trata de sus ojos. diciendo: Tus ojos son de paloma. Hay algunas palomas hacia levante las cuales algunos han traído hacia acá y las llama[n] tripolinas; estas tienen muy hermosos ojos y de un color

\footnotetext{
${ }^{194}$ El espiritu: entiéndase el sentido espiritual. Se da frecuentemente a lo largo de todo el texto.

${ }^{195}$ Los vocablos cánfora: deberia ir en singular, pues este el único vocablo que se explica.

${ }^{196}$ En el manuscrito, Josué (5). Se trata de un error. Se refiere a Jasué (15, 61-62)

197 Lo cual: esta relativa no aparece en femenino porque no va referida a Esposa, como en principio podria pensarse, sino a la proposición de infinitivo que le sigue.

${ }^{198}$ Por eso: se retoma la construcción comenzada cinco líneas más an iba $(Y$, porque...)
} 
extraño, que parecen fuego vivo. $Y$, en los sacrificios que se hacían, cuando se había de oferecer paloma, para prueba de su hermosura y divinidad solamente le miraban los ojos y, siendo hermosos, era juzgada por buena para el sacrificio. Por eso ei Esposo dice que su Esposa tiene tanta perfección en su beldad que, siendo toda hermosa, el remate y fin de su belleza es hermosísimo, que son los ojos tan lindos como los de paloma.

En todos los demás lugares de la Sagrada Escritura donde hallamos paloma se da a entender simplicidad y candor cristiano[s] ${ }^{199}$ y inocencia de vida y lealtad en el amor y fe. Como lo declara el mismo maestro en su Evangelio, por los ojos se entiende, en una significación propia en este lugar, el entendimiento y afecto del hombre, como se ve en aquel dicho que dice: $L a$ lucern $a^{200}$ de tu cuerpo es tu ojo; y también en aquel que en el mismo evangelista se halla: $S i$ tu ojo es malicioso ${ }^{201}$. Pues, loando el Esfoso a la Esposa en esta manera, da a entender que su entendimiento y afectos son simplicísimos y puros, y que otra cosa no piensa ni desea sino su Esposo, y en este amor tiene puestos los ojos y todo su deseo [aie] que ojalá la tierra la pueda apartar de esta libertad de amor, así como la paloma tiene puesto todo su amor en su compañero sencillamente sin amar a otro.

¡Y tú eres hermoso, amor mío, y también gracioso! Nuestra cama es florida y nuestras casas son de cedro; nuestros corredores, de cipreses. Responde ${ }^{202}$ la Esposa al testimonio de loor que su Esposo acerca de su belleza había dado, conociendo y publicando la hermosura de él. Y porque la belleza no sólo está en la exterior muestra asentada, es decir, de $\mathrm{d}^{203}$ la proporción de los miembros y escogida pintura de naturales colores, $\operatorname{mas}^{204}$ también y principalmente tiene silla en la ánima [y porque esta parte de la hermosura del ánima se llama gracia y se muestra de fuera y se da a entender en los movimientos de la misma ánina] -como son andar, mirar, hablar. etc.-, [los cuales todos generalmente en la lengua toscana se llaman atti-; de tal manera] que sin esta belleza no tiene sal ni gracia la otra del cuerpo, antes es una frialdad y menos de amar que una bella imagen pintada; como lo vemos vulgarmente, que ${ }^{205}$ hay algunas personas de buen parecer y que al juicio de los sentidos son sentenciadas por hermosas, mas, siendo considerados los movimientos que de la ánima proceden, (los cuales todos generalmente en

${ }^{199}$ Cristiano[s]: en singular, concuerda únicamente con el más cercano de los dos sustantivos a los que califica.

${ }^{200}$ Lucerna: abertura alta de una habitación que da ventilación y luz (DRAE, 2).

${ }^{201}$ En el manuscrito, San Mateo (10), (5), (21).

${ }^{202}$ El párrafo que aqui comienza presenta muy serios problemas de comprensión, debidos probablemente a la transmisión del manuscrito. Dado que, en gran parte de él, se sigue casi literalmente el pasaje paralelo de la Exposición según la letra, hemos intentado rehacerlo, son adiciones y eliminaciones que se irán sef̂lando. De todos modos, sigue quedando cierta cscuridad en el pasaje. Transcribimos a continuación el mencionado párrafo paralelo: "Responde la Esposa y paga en la misma moneda al Esposo, conociendo y publicando la hermosura que hay en el. Y, porque la belleza está, no solamente asentada en la exterior muestra dé la buena proporción de facciones y escogida pintura de naturales colores, mas también y principalmente tiene su silla en el ánima; y, porque esta parte de la hermosura del ánima se ilama gracia y se muestra de fuera y se da a entender en los movimientos de la misma ánima -como son mirar, hablar, reir, cantar, andar y los demás, ibs cuales todos en lengua toscana generaimente se llaman atti-, de tal manera que, sin esta belleza, la otra del cuerpo es una frialdad sin sal y sin gracia, y menos digna de ser amada que lo es una imagen, como cada dia se ve; así que, por esta causa, la Esposa, para lcar perfectamente a su Esposo, le dice: Y tú eres hermoso y gracioso".

${ }^{203}$ De. en.

${ }^{204}$ Mas: equivalente a sino.

${ }^{205}$ Lo vemos... que: el pronombre neutro lo recoge y anticipa a la proposición completiva 
lengua toscana son llamados $\left.a t t i^{206}\right)^{237}$, los condenan por fríos y desgraciados, y los aborrecen; de donde es muy celebrado el dicho de aquel muy gran sabio de los gentiles que, estando en su presencia uno afamado por gentil mancebo, le dijo: "Habla porque $e^{208}$ te yo te vea", dando a entender que lo principal de la hermosura le faltaba de conocer en él para juzgarlo por tal.

Esta perfecta y total belleza conoce la Esposa estar en su Esposo como en propio templo de la misma beldad. Y, así, dice: Tú eres hermoso, amor mio, y también gracioso. En el hebreo, está en dos lugares, del Esposo y de la Esposa, una palabra que en latín se interpreta ecce y es voz que en esta parte es muestra de grande afecto y regocijo del que ama; como que, estando contemplando la beldad amada, no cabe en sí ni puede tener el ímpetu de la alegría que con gran fuerza dentro le mueve, y dice: "¡Ay, ay, cómo eres hermosa! $\mathrm{¡} A y$, cómo eres hermosa, amiga mía!"; o otra tal razón de impetuoso afecto, lo cual no se puede pintar al vivo con la Sagrada Escritura, porque el dibujo de la pluma no se entiende a más que a cuanto la lengua lo traza. Y porque, comc la belleza -como habemos ${ }^{209}$ dicho- tanto más apetito causa de ser gozada cuanto mayor ella es, por eso en el mismo punto la Esposa considera cuán hermoso sea su Esposo. Es movida con el deseo de gozarla, y luego le convida y ruega con los aparejos comodidades que hay para ello-, diciendn que se venga a su casa, la cual es muy bien hecha, así de fábric d $^{210}$ y arquitectura como de preciosos materiales, como son cedro y aciprés ${ }^{211}$ madera olorosa y preciada y recial que mucho tiempo dura-; y que dentro tiene una muy gentil cama, toda cubierta de rosas y flores, según se usaba entonces entre los enamorados, como en los antiguos escritores se lee.

El espíritu de estas palabras es el mismo sentido de la letra, porque está claro y evidente el testimonio de la hermosura y gracia del espiritual Esposo. Pues que de su hermosura se dijo: Escogido en hermosura sobre los hijos de los hombres; y de su gracia también en el mismo lugar: Bañados están tus labios en gracia ${ }^{212}$, en el cual los labios significan el hablar gracioso de este Esposo, que era tan suave que atraía a sí [a] los oyentes y no se podían despegar de él, como uno de ellos los metió en público, diciendo: ¿Dónde quieres que vamos ${ }^{213}$, que tienes unas palabras de vida eterna? ? $^{214}$. Querría, pues, la Esposa gozar de esta belleza; mas, como

\footnotetext{
${ }^{206}$ Atti: eri el manuscrito encontramos alli. Realizamos la sustitución por parecernos un claro error del copista.

${ }^{207}$ Eliminamos este fragmento, ya insertado más arriba.

${ }^{208}$ Porque: valor final.

${ }^{209}$ Habemos: esta es la única ocasión a lo largo de todo el texto en que aparece la forma habemos -en lugar de hemos- para la formación del pretérito perfecto de indicativo.

${ }^{210}$ Fábrica: acción y efecto de fabricar (DKAE, 1).

211 Aciprés: ciprés.

${ }^{212}$ En el manuscrito, Saimo 44 (45). El titulo de este Salmo es Poema nupcial al rey mesiánico.

${ }^{213}$ Vamos: uso del indicativo donde actualmente se utilizaria el subjuntivo.

214 I San Pedro $(1,25)$.
} 
tierna y flaca, no querría salir de su casa y contento sino que fuese posible alli fuese su Esposo; mas él la llama y procura (de $)^{215}$ sacarla de este regalo, como adelante veremos, etc.

\section{CAPITULO [W"}

[Yo soy rosa del campo y lirio ${ }^{217}$ de los valles. Como el lirio entre las espinas, así mi amiga entre las hijas. Como el manzano entre los árboles silvestres, asi mi Esposo entre los hijos; cuya sombra yo deseo, y debajo de ella me asentaré, y su fruto ${ }^{218}$ es dulce a mi paladar. Metióme el rey en la bodega y su guia para mi es el amor. Esforzadme con vasos de vino. Tended debajo de mi manzanas, que estoy enferma de amor. Su izquierda debajo de mi cabeza y su diestra me abrace. Conjúroos, hijas de Jerusalén, por las cabras montesas y las ciervas del campo, que no despertéis ni quitéis de su reposo a ni amada hasta que ella quiera. ¡La voz de mi amado! ¡Helo ${ }^{215}$ ! Viene atrancando ${ }^{220}$ por los montes, saltando por los collados. Semejante es mi amado a la cabra montesa o al ciervecito. iHelo! Está tras la nuestra pared, mirando por las ventanas y acechando por las rcjas. Hablóme el mi amado, dicienio: ¿Levántante, amiga mia, y vente! Ya pasó el invierno, la lluvia se retrajo, el tiempo de cantar es venido y en nuestra tierra se oyó la voz de la tortolilla; la higuera ha ya mostrado sus botones, las vides dieron su olor. ;Levántate y vente, amiga mia! Palnma mia, en las cuevas de la piedra y en los agujeros de la subida me muestra tu vista. Haz que yo oiga tu voz, porque tu voz es dulce y tu vista bella. Tomad las raposas, las raposus pequeñas que destruyen las viñas, y nuestra viña ha mostrado su agraz. Mi amado para mi y yo para él, el cual apacienta entre las violetas. Hasta que sople el dia y huyan las sombras. Tornándote, parezcas, amado mio, a una cabra, a un ciervecito sobre los montes de Beie! $\left.!^{221}.\right]^{222}$

\section{[EXPOSICIÓN]}

\footnotetext{
215 (De): suprimimos la preposición, dado que según los usos actuales, resulta innecesaria, al tratar se de un verbo transitivo.

210 [II] : realizamos esta la adición y suprimirnos lo que hemos encontrado en el manuscrito ( $z^{\circ}$ ) en un intento de homogeneizar los titulos de los capitulos.

217 Lirio: alternan en nuestro texio la forma lirio con la más arcaica lilio. Hemos homogencizado.

218 Fruto: a to largo del inanuscrito alterna la forma fruto con la más arcaica fructo. En la modernización, hemos optado por la homogeneización.

${ }^{219}$ Helo: exclamación procedente del latin, ecce illum.

${ }^{220}$ Atrancar: dar trancos o pasos largos (DRAE, 3).

${ }^{221}$ Betel: en el manuscrito excontramos la forma Berhel.

$2.22 \mathrm{Al}$ izual que hicimos en el primer capitulo intentando homogeneizar estos dos capitulos con los demás, aftadimos aqui el texto del capitulo completo de la traducción del Cantar que se va citanto al principio de ias explicaciones. Las palabras que, al principio, aparecen en letra redonda están asi para diferenciarlas, dado que no aparecen en este texto y las hemss repuesto en base a la traducción que aparece en el Comentario segun la letra, aunque no copiando literalmente, sino intentando armonizarlas con el resto de esta traducción.
} 
Yo soy rosa del campo y lirio de los valles etc.

Estas palabras son del Esposo, el cual, queriendo alabar a su Esposa y mostrar cuán bien convengan los dos para este desposorio, primerc declara sus propiedades y luego las de su Esposa. Lice que él es rosa y ella es lirio. Bien está, cierto, la rosa con el lirio, porque ambos juntos dan buen olor y parecen bien a la vista y también, siendo entrambas ${ }^{223}$ rústicas flores, cuadran bien la una con la otra. El uno rosa del campo y el otro lirio entre las espinas, que las espinas no crecen en los huertos cultivados -por el cuidado que se tiene de arrancarlas-, sino en los campos y lugares silvestres, donde sola la naturaleza es hortolana ${ }^{224}$; allí crecen las espinas y allí, en medio de ellas, muchas veces los lilios. Así que estas flores, juntas, harán un gentil ramillete y se concertarán bien en vista y olor. Y este es el sentido de la letra.

Claro está que este Espcso de quien aquí se trata es rosa y bella rosa de Jesée ${ }^{225}$; rosa dol campo, no sembraća ni cultivada por manos de hombres, sino rosa que ella misma se nación 226 al mundo y se abrió y manifestó a los ojos de todos y dio su olor suavísimo de suyo; y, porque no por las obras de justicia que hicimos nosotros, sino según su misericordia, usó de gran cortesía y amor con nosotros, se llama también "flor del campo". Están en parte baja, donde cualquiera $1 \mathrm{~s}^{227}$ pueda ver y gozar de ellas y de su olor. Y están puestas descubiertas a todos los vivientes que las combatan y que todas las bestias que no las conocen la[s] huellen ${ }^{228}$, y no por eso se marchitan; antes, mientras más las huellan más avivan su olor, como lo vemos en todas las otras cosas que naturaleza de suyo produce, que el mal tratamiento y hailamiento de los hombres les aprovechan y, si las queremos plantar por nuestras manos y regarlas, se nos pierden. Todo esto pertenece y se dice muy bien de este divino Esposo, fior maravillosa cuyo nombre y fama es $^{229}$ de suavísimo, expuesto y manifiesto en el campo del mundo. Puesto por señal que muchos contradicen, muchos procuran ahogar esta suavísima flor, mas su virtuc̉ sobrepuja ${ }^{230}$ y vence [a] sus contrarios, y ellos quedan burlados y afrentados, y el olor de su farna cunde y trasciende más, como se ve claro en el salmo segundo ${ }^{231}$.

El mismo sentido es el de las palabras que se siguen -Lirio de los valles-porque es repetición de la misma sentencia en diferentes palabras, como arriba se ha visto en otros lugares y es así el uso de la Sagrada Escritura para declarar más la cosa o poner mayor fuerza en lo que dice. Y no tenemos más que notar en esto sino que lo que traducimos lirio está en la letra hebrea sostamin, que quiere decir "flor que tiene seis hojas". Cuál sea o cómo se llame

\footnotetext{
${ }^{223}$ Entrambas: ambas. Forma antigua.

${ }^{224}$ Hortolano: hortelano. Forma antigua

225 Jesé: vara de Jesé: nardo planta (DRAE).

${ }^{226}$ Nacer (prnl.): entallecerse una raiz o semilla al aire libre (DRAE, 14)

${ }^{227}$ Los: la concordancia de la oración nos haria esperar aqui una forma femenina.

${ }^{228}$ Hollar: pisar.

${ }^{229}$ Es: concuerda en singular únicamente con el más cercano de sus dos sujetos.

${ }^{230}$ Sobrepujar: exceder una cosa o persona a oira en cualquier linea (DRAE)

${ }^{231}$ Salmo titulado Gloria del rey mesiánico.
} 
acá no cstá muy averiguado, ni tampoco es muy necesario saberio; parece ser alhelí o especie de violeta que graciosamente huele.

Habiendo, pues, dicho al Esposo qué sea él, dice luego que su Esposa es un lirio ${ }^{232}$ entre espinas, porque esta Iglesia, nacida en fe, no es obra de los hortolanos del mundo, que por [sí] sola y favor diel cielo se produce y sustenta; mas está cercada de espinas por la muchedumbre de las diversas sectas de infidelidad y herejías y supersticiosas creencias que en derredor de ellos están, las cuales procuran (de) ${ }^{233}$ ahogarla; empero ${ }^{234}$ tanto más crece(n) ${ }^{235}$ cuanto más la pretenden destruir, porque la ayuda del sol celestial está con su calor, donde le fuerza para que sobrepuje los trabajos que la rodean, así como vemos acá naturalmente. Y yo alguna vez la ${ }^{236}$ noté en una hierba, la cual, estando en campo zaso, no crecía más que un palmo; y la vi entre algunas matas de más de tres a cuatio palmos crecida por el apetito que tenía de salir a gozar del sol que la conserva y da vida, y las plantas que la cercaban con hacerle sombra al pie se lo tenían fresco y húmedo, de donde venía su crecimiento a ser mayor y sobrepujar a sus enemigos. Tal es esta Esposa, este lirio entre espinas, esta gentil flor que, a pesar de las enemigas plantas, crece y se muestra a la vista de todos. Tiene otro privilegio la flor que se cría entre espinas: que es tanto más amada y preciada cuanto más son aborrecibles las espinas, y de la fealdad de ellas [se] viene a conocer más su hermosura y ser más estimada(s) ${ }^{237}$, lo cual es muy claro de entender de esta Esposi.

La letra dice así: Mi amiga entre las hijas. Cuando los hebreos dicen "hijas de Jerusalén", "hijas de Tiro", o otra tal conjunción de palabras, significan todas las mujeres de aquel lugar casadas y solteras, vírgenes, niñas y viejas-; mas, cuando ponen "hijas" absolutamente ${ }^{238}$, las más veces lo dicen por las doncellas o mujeres que aún no están en poder de sus maridos, sino que están más al mandado de sus padres que al de otra persona.

Como el manzano entre los árboles silvestres, asi mi Esposo entre los hijos; cuya sombra yo deseo, y debajo de ella me usentare, y su fruto es dulce a mi paladar.

Responde la Esposa, según su uso, en alabanza de su Esposo. Y, porque él en sus loores la había comparado a rosa entre espinas, lo compara ella también en esta loa -comparación también rústica, mas muy elegante-, diciendo que, [como] entre los árboles que nacen en las seivas es muy aventajado un hermoso manzano dulce, así su Esposo vence en bondad y excelencia a todos los otros mancebos; que quiere decir a todos los dioses de los gentiles y sus vanas religiones. Y ella misma declara en la letra la ventaja que hace el manzano a las otras

\footnotetext{
${ }^{232}$ Liriv: hasta ahora, en el manuscrito habia aparecido únicamente la forma lilıo. Curiosamente, a partir de ahora será lirio ia única forma que aparezca.

${ }^{233}$ (De) suprimimos la preposición por tratarse de un verbo transitivo, no necesitado de ella según los usos actuales.

${ }^{234}$ Empero: conjunción desusada. Además de un valor adversativo equivalente a pero, puede equivaler, como es este caso, a sin embargo

${ }^{235}$ Crece(n): suprimimos el morfema de plural, dado que el sujeto de este verbo es Iglesia.

${ }^{236} \mathrm{La}$ : en este jronombre se recoge la idea de la oración anterior para poner un ejemplo; de este modo deberia aparecer en género neutro Suponemos que el femenino viene dado por ser a la Iglesia a quien se refiere el ejemplo.

${ }^{237}$ Estimada(s): suprimimus el morfema de plural, dado que se refiere a flor.

${ }^{238}$ Absolutamente: de manera absoluta (DRAE, 1). Absoluto: independiente (DRAE, 2)
} 
plantas, que es muy hermoso en grandeza, de donde viene a tener muy gran sombra y muy más fresca que los otros, por ser su naturaleza más mansa y delicada; y su fruto dice que es muy duice para comer. De manera que defiende del calor y ayuda a la salud con su sombra liviana y conserva la vida con el manjar de su fruto; mas los árboles montesinos todo al contrario, como quiera que son sin fruto, sin buena sombra ni hermosura, y no buenos sino para el fuego.

Estas propiedades del manzano no solamente las muestra ella por el común sentido de todos, que no hay quien lo niegue, sino por prueba y experiencia suya, diciendo: "Tiene muy linda y liviana sombra, porque yo, viéndome alguna vez cansada, deseé hallar fresca sombra donde reposase y la hallé so ${ }^{239}$ el manzano y me senté en ella y reposé y cobré fuerzas con comer de su fruto, el cual, demás ${ }^{240}$ de ser provechoso, era muy dulce a mi gusto; pues, tal es mi Esposo entre los otros dioses que los otros no son sino mentiras, dioses vanos sin ningún refrigerio ni provecho para quien a ellos se arrima, estatuas buenas para el fuego"; y, como dice Isaías, para cocer con ellas la olla: El mio es Diss que con su sombra ampara y con el dulce fruto de su palahra harta y da vida ${ }^{24 !}$.

Dice la letra: Mi Esposo entre los hijos, que quiere decir "entre los mancebos", conforme a lo de arriba.

Metióme el rey en la bodega y su guia para mi es el amor. Esforzadme con vasos de vino. Tended debajo de mi manzanas, que estoy enferma de amor.

Forzado está cualquiera que no está fuera del ser de hombre a amar a aquella persona que le ama, y, en amándola, [a] fiarse de ella y dejarse llevar muy seguro y sin cuidado y sin recelo por donde el otro quisiere, porqlie el amor es padre de la confianza y, al contrario, el desamor es principio de la sospecha. Y nunca va el hombre con sospecha, si no es por parte donde piensa que no le quieren bien. Tiene bien entendido el amado que quien le ama no le lleva sino a donde sea más su provecho que daño; $y$, como después lo ve así suceder y siente los beneficios de quien bien le quiere, se le aumenta en gran manera el amor, porque es averiguado que los dones y beneficios, aunque no sean causa del nacimiento del verdadero amor todas veces, a lo menos son parte del mantenimiento con que se sustenta y conserva. Esto que hemos dicho está en las palabras de la Esposa, la cual dice que, sabiendo ella cómo su Esposo la ama mucho, se dejó llevar y guiar de este amor muy segura; y su rey y Esposo, que la llevaba, la metió en su bodega, donde parece que la convidó a beber de algún extremado ${ }^{247}$ vino, porque, diciendo que la llevó a la bodega, se entiende que bebió allá; como acá, en diciendo uno "ayer estuvimos en la bodega de fulano", entendemos que comió y se regocijó en ella.

Luego que la Esposa bebió del generoso vino de su Esposo, con este beneficio se le aumentó el amor en gran crecimiento. Y, acordándose ahora de esto, la imaginación le mueve las entrañas a amor, y crece tanto en ella este amor que la hace desmayar; $y$, porque los

\footnotetext{
${ }^{239}$ So (3): bajo, debajo de (DRAE). Esta prepcsición c. ece actualmente de uso general, utilizéndose sólo son ciertos sustantivos ya fijados, como pena.

${ }^{240}$ Demás: además.

${ }^{241}$ Alusión biblica sin anotación al margen en el manuscrito. Isaias $(44,6-20)$.

${ }^{242}$ Extremado: sumamente bueno o malo en su género (DRAE, 2).
} 
desmayos suelen tener por remedio buen vino y cosas olorosas para que revoquen el corazón en su fuerza y torne en sí el enfermo con tales socorros, demanda la Esposa que le traigan vasos de la bodega de su Esposo para que rocien y le den de beber, y le pongan debajo buenas y olorosas frutas, porque con estas ayudas se sustente la virtud de su corazón y esté firme su persona, que parece que se va a caer. Y, por eso dice: Esforzadme con vasos. Tened debajo de mi manzanas, que estoy enferma de amor. En decir esforzadme se da a entender el desfallecimiento de la fuerza, que se iba a caer. Y diciendo tened debajo de mi manzanas se da a entender que ella estaba ya caída y recostada, y esto todo al principio del desmayo. Y lo que dice estoy enferma de amor no es la enfermedad propia del cuerpo, sino una grande aflicción del ánimo que la imaginación de alguna cosa causa, y de aquí se sigue desfallecimiento de la fuerza del cuerpo.

Este desmayo de la Esposa, en el espíritu, es un gran deseo que la mueve a amar tierna y apasionadísimamente, habiendo sentido el amor que su Esposo le tiene y los beneficios que de él ha recibido. Y, en este amor espiritual, se profunda ${ }^{243}$ tanto que viene a sentir sus desmayos y desfallecimientos y tristezas espirituales, o por verse indigna de tal amor y de tantos beneficios o por el mismo amor que en ella está; el cual, de su naturaleza, mientras mayor es más movimientos hace dentro en el pecho donde reina, como los experimentos muy bien lo entienden; $y$, muchas veces, estos desmayos nacen de alegría grande que en los enamorados se levanta y los alborota dentro. Estando, pues, la Esposa de esta manera desmayada, demanda los refrigerios del vino de la palabra Dios, que esto significa por la mayor parte el vino en los Santos Libros, como se ve en los consejos de la Sabiduria, que, convidando a los hombres al estudio de la palabra divina, los dice ${ }^{244}$ : Venid $y$ bebed del vino que tengo aqui aguado, $y$ aparejado para vosotros ${ }^{245}$. Y lo mismo se señala por las manzanas y frutos que aquí demanda. Como ya arriba vimos de un tal desmayo se debía sentir desmayado aquel regalado, enamorado David, que tales epítimas ${ }^{246}$ demandaba para esforzarse cuando decía: Señor, desmayada está mi ánima deseando aquella salud que tú le has de dar y has prometido, y tengo yo gran confianza en tu palabra; los ojos tengo cansados atendiendo a la promesa y cumplimiento de tu palabra y nunca hago sino decir cuándo me consolarás ${ }^{247}$.

\section{Su izquierda debajo de mi cabeza y su diestra me abrace.}

Prosigue la enamorada demandando socorro para su desmayo. Ningún remedio mayor hay para los que se desmayan que ver junto consigo aquello que ama[n], y que le[s] muestren favor y le[s] den señales de amor; porque ellos tienen entendido que de allí les viene su trabajo y de allí mismo les puede venir el alivio y descanso. Por tanto, estando ya la Esposa caída en el desmayo, dice: " $\mathrm{OOh}$, si mi Esposo viniese y debajo de mi cabeza pusiese su brazo izquierdo y con el derecho ciñese mi cuerpo!" Esias palabras son figura de uno que tiene abrazada [a] alguna persona que se desmaya y la quiere bien: se sienta y pone la cabeza del desmayado

\footnotetext{
${ }^{243}$ Profundor: ir a lo profundo, ahondar (DRAE).

${ }^{244}$ Los dice: caso de loísmo. No es un fenómeno aislado en este texto; a aparece en algunas ucasiones más. No creemos necesario seffalar cada aparición.

${ }^{245}$ Alusión biblica sin anotación al n:argen en el manuscrito. Sabiduria $(2,7)$.

${ }^{246}$ Epitima: consuelo, alivio (DRAE, 2).

${ }^{247}$ Alusión biblica sin anotación al margen en el manuscrito. Salmo 31, titulado Súplica y acción de gracias de un afligido.
} 
encima del su brazo izquierdo y con el derecho le abraza. Y esto hemos de entender que lo dice la Esposa en aquellos intervalos del desmaye cuando torna en sí, como se ve en los que tal pasión sienten, que se trasponen y tornan en sí hablando algo de aquella materia que los hace desmayar y luego se tornan a trasponer, durando esta batalla [hasta] que la fuerza del corazón venza aquel contrario humor ${ }^{248}$ que lo fatiga y causa tal falta de exterior sentimiento.

En el espíritu de estas palabras, la Esposa, desmayada, para tornar en sí y estar muy alegre en este amor, demanda la certidumbre y presto socorro de las manos de Dios, que las tenga y sienta ella en su favor ${ }^{249}$. La izquierda, que, puesta debajo de su cabeza, le haga pasar en esta vida con gran tolerancia la cruz y los trabajos de ella y no deje de sustentar[la] en todas sus adversidades y tenerle la cabeza (del buen propósito en que prosigue, que no llegue a la tierra, lo cual Dios suele hacer muy de buens gana; y, cierto, como lo testifica la Sagrada Escritura diciendo del bueno y enamorado, del que cuando fuere a caer no caerá, porque él pone la mano debajo ${ }^{250}$. [D]el otro brazo con que la Esposa desea ser abrazada, que es el diestro, entendemos la vida eterna, aquella diestra donde está asentado el hijo de Dios, la cual diestra desea grandemente gozar el divino enamorado. Con estos dos brazos de Dios siente gran consuelo y gran alegría en sus desmayos, viendo el favor acá muy presto para socorrerle y esperando la vida eterna, que la cierta esperanza del bien venidero pone grandes ánimos para sufrir cualquier trabajo presente.

Conjúroos, hijas de Jerusalén, por las cabras montesas y las ciervas del campo, que no despertéis ni quitéis de su reposo a mi ainada hasta que ella quiera.

Es naturai, después del desmayo, el sueño, porque la virtud, cansada de la pasada lucha, sosiega ${ }^{251}$ y torna en sí con el socorro del reposo. Y, así, parece aquí por las palabras del Esposo que ella, después del desmayo, no torna en sí luego, sino queda dormida, pues él le está guardando el sueño; y esto es muy común a los que bien quieren, tener ${ }^{252}$ gran cuidado del reposo y sueño de quien aman, poniendo silencio en los circunstantes. Y, porque la Esposa se introduce aquí muchas veces acompañada de otras doncellas y, en las palabras de ella cuando demandaba vino y olores, parece que estaban allí algunos presentes a su desmayo, viene el Esposo a encomendarles mucho que la dejen reposar.

Estas doncellas parece que son cazadoras en la conjuración que el Esposo les hace, y es muy conforme a la imaginación tomada en este libro, porque a la Esposa pastorica las compañeras han de ser rústicas y que tengan ejercicio del campo, cono es ser pastoras y cazar;

\footnotetext{
${ }^{248}$ Humor: cualquiera de los liquidos del cuerpo del animal (DRAE, 1)

249 Que... favor: en la sintaxis del español, como en la latina, se construyen a veces ciertas proposiciones de relativo con subjuntivo indicando algun valor circunstancial. Asi ocurre en este caso, donde se puede apreciar un valor consecutivo. Resulta tambien digno de mención el hecho de que, en nuestro texto, como en este caso, en numerosas ocasiones no se deja claro cuál sea la función sintáctica del relati:o -asi ocurre, por ejemplo, cuando realiza alguna función circunstancial y aparece sin preposición ninguna-. Normalmente lo encontramos solo, al principio de la proposición - tı una función que podria llamarse "enunciativa"-, para dejar paso después a algún pronombre que cumpla la función sintactica que a èl le corresponderia. Asi ocurre en este caso con el pronombre las, que realiza la función de C.D.

${ }^{250}$ Alusión biblica sin anotación al margen en el manuscrito. Salmo 118, titulado Himno para la fiesta de los tabernáculos.

${ }^{251}$ Sosegar (intr.): descansar, reposar, aquietarse o cesur la turbación o el movimiento (DRAE, 4). Actualmente es mas común el uso de este verbo en forma reflexiva.

${ }^{252} Y$ esto... tener: se trata de una construcción caracteristica, no aislada en este texto: una oración cuyo sujeto es un demostrativo neutro, desarrollàndose después en una proposición de infinitivo yuxtapuesta.
} 
y este era uso de tierra de Asia, principalmente hacia Tiro y en aquellas comarcas de Judea, que las vírgenes ejercitasen ${ }^{253}$ en la caza. $Y$ así las requiere y ajuramenta el Esposo, diciendo: "Ruégoos y requiérocs, hijas de Jerusalén, así os vaya siempre bien en la caza, así gocéis de las ciervas y hermosas cabras montesas, que no despertéis a mi amada hasta que ella quiera y de suyo se despierte". Esta es comunísima costumbre de todos los buenos autores, y aun de todas las gentes, orar la felicidad o desgracia del estudio y ejercicio del otro cuando lo quiere rogar algo o cuando le desea mal; que a uno que estudia decimos: "así Dios os haga un gran letrado"; y a uno que pretende dignidades: "así yo os yea un grandísimo [señor] ${ }^{254 n}$; al marinero: "así Dios os dé buenos viajes"; y así en todos los demás.

En el sentido escondido de estas palabras se muestra el cuidado que Dios tiene de su Esposa y de su reposo; porque, estando allá dormida después de los amorosos desmayos, que es cuando está apartada y ajena de los cuidedos del siglo ${ }^{255}$ y que parece muerta al mundo, encomienda mucho el Esposo a las hijas de Jerusalén, a todos los que pertenecen a su pueblo, que no la alboroten, que no tengan en poco su reposo y su sueño, no la calumnien, ni la vacillen $^{256}$; antes, la dejen estar en su simplicidad y la defiendan y la conserven en ella; $y$ esto le[s] requiere por las cabras y ciervos del campo, que, en este sentido, son los ejércitos del cielo y las otras divinas virtudes, las cuales todas serán en venganza y castigo de quien lo contrario hiciere.

Otro lugar notamos aquí bonísimo y de gran consuelo para los enamorados de Dios, y es la certeza del divino socorro; porque, estando la Esposa en sus desmayos, deseaba la presencia y abrazos de su Esposo, y él estaba tan cerca que la sintió desmayar y la vio dormida, y le procura guardar el sueño. No olvida Dios un punto a los que ama ni los deja un momento solos en las tribulaciones, como se ve por todas las Divinas Historias, que está siempre al lado de los que bien quiere. ¡Oh, cuán bien lo había probado el que decía!: Él estará a mi diestra porque no me perturbe ${ }^{257} ; \mathrm{y}$, en otra parte: Aquel me estuvo a la diestra de un pobre y desamparado del mundo, como yo para librar mi vida de los que la perseguian ${ }^{258}$.

¡La voz de mi a,nado! ¡Helo! Viene atrancando por los montes, saitando por los collados. Semejante es mi amado a la cabra montesa o al ciervecito. ¡Helo! Está tras la nuestra pared, mirando por ias ventanas $y$ acechando por las rejas.

Es el cuidado del amor tan grande y está tanto en vela en lo que desea que, de mil pasos, como dicen, lo siente; entre sueños lo oye y tras los muros lo ve. Firalmente, es de tal naturaleza el amor que hace obras en quien reina diversas ${ }^{259}$ mucho de la común opinión de los

\footnotetext{
${ }^{253}$ Ejercitarsen: de nuevo un uso absoluto de uri verbo comunmente utilizado hoy de modo pronominal.

${ }^{254}$ [Señor]: completamos la oración segun el pasaje análogo del Comentario según la letra

${ }^{255}$ Siglo: comercio y trato de los hombres en cuanto toca y mira a la vida civil y politica, en oposición a la vida religiosa (DRAE, 4).

${ }^{256}$ Vacillen: forma antigua de vacilar: moverse indeterminadamente una cosa (DRAE). En nuestro texto, utilizado de modo transitivo; actualm.ente, de uso intransitivo.

${ }^{257}$ Alusión biblica sin anotación al margen en el manuscrito. Salmo 16, titulado Súplica del justo contra sus perseguidores.

${ }^{258}$ Alusión biblica sin anotación al margen en el manuscrito. Salmo 118, titulado Himno para la fiesta de los rabernáculos.

${ }^{259}$ Obras... diversas: fuerte hiperbaton.
} 
hombres. Y, por esto, los que no sienten tal afecto en si experiencia no creen o los parece milagro -o, por mejor decir, locura- ver y oír las tales cosas en los enamorados. Y de aquí resulta que los autores que tratan de amor son mal entendidos, y juzgados $\mathrm{de}^{260}$ algunos autores de devaneos y disparates. Por lo cual, un antiguo poeta enamorado de nuestra nación, honesto y muy entendido, hizo principio a sus canciones, diciendo en su lengua lemosina ${ }^{261}$ semejante seña $a^{262}$.

\section{No vea mis escritos quien no esté triste, \\ O quien no ha estado triste en tiempo alguno. ${ }^{263}$}

Así que las extrañas cosas que sienten, hacen y dicen los que aman no se pueden entender $\mathrm{de}^{264}$ los libres de amor; [de] ${ }^{265}$ donde será forzoso que muchas cosas de este libro sean escuras $^{266}$, así al compositor de él como a los demás que en el divino amor están fríos; y, por el contrario, será muy claro todo al que tuviere en sí la seña de esta obra, y ninguna cosa le parecerá imposible ni disparatada.

Vemos aquí que la Esposa, cansada del trabajo pasado, está durmiendo; y, con todo, en el punto que su Esposo habla, siente su voz y la conoce sin errarla y se avisa de su venida, diciendo: ; $L a$ voz de amado! En las cuales más palabras se muestra que é ${ }^{267}$ habla con apresurado ímpetu, como persona que súbitamente siente cosa que le mueve y le da nuevo aliento, como es costumbre de todas las personas que con tal afición hablan. Luego prosigue: "Mirad cómo ha venido y cuán presto; porque, estando él allá en el campo, no le ha estorbado la largueza ${ }^{268}$ ni dificultad del camino que en un punto no se hallase aquí a ayudarme. De monte en monte, de collado en coilado, ha venido saltando y atrabancando ${ }^{269}$ con tanta ligereza como cabra montesa o como un ciervecito"; porque estos animales son de los más prestos en

\footnotetext{
${ }^{260}$ Juzgados de: actualmente, seria más normal juzgados como.

${ }^{261}$ Lemosin: lengua provenzal (DRAE, 3).

${ }^{262}$ Seña: por su uso en otros contextos, parece ser que se utiliza esta palabra con el significado de sentencia.

${ }^{263}$ Todo este pasaje -como los párrafos que le preceden y siguen- es casi literal al pasaje paralelo del Comentario según lc letra. También esta cita es la misma. Por ello, transcribimos la nota al pie que da el P. Merino: "Este Poeta, que no nombra el Mtro. Leon, es sin duda Ausias March, célebre Poeta Lemosin, llamado con razon al Petrarca espafiol, el qual en su primera cantiga del amor dice: Qui no es trist. de mos dictats nor cur / O en algun temps que sia trist estat. Estos versos endecasílabos los traduxo el Mtro. Leon á otros dos castellanos de igual mensura. Fué cur, / Oen algun temps que sia trist esta. Estos de Catalufia: vivia, y era célebre por los affos de 1440, y murió en el de 1460. Nota del Mtro. Fr. Diego Gonzalez."

${ }^{264}$ No se pueden entender de los libres de amor: nuevo caso del ya sefialado uso de la preposición de para el complemento agente. Resulta digno de mención, además, el la aparición del complemento agente con la pasiva refleja, no infrecuente en nuestro texto y un tanto extraño a los usos actuales.

${ }^{265}$ [De]: volvemos à completar en base al Comentario seguin la leira

${ }^{266}$ Escuro: oscuro. Uso antiguo y hoy rulgar.

${ }^{267}$ Él: parece un claro error del copista. Léase ella. No obstante, cabe otra posibilidad, considerando el como un articulo; en este caso, siendo habla un sustantivo, faltaria el verbo de esta proposición.

${ }^{268}$ Largueza: largura

${ }^{269}$ Atrabancar: pasar o saltar de prisa, saltar obstácuios (DRAE, i).
} 
saltar y más atrevidos en lugares peligrosos, así por la ligereza de sus pies como por su aguda vista, con que en un momento comprende[n] donde han de caer seguros.

Ya, cuando la Esposa esto dice, el Esposo estaba a su puerta, como está claro por las palabras que éi dijo a las doncellas que con la Esposa estaban, y por lo que ella ahora dice: "¡Helo! Ha venido". Hablando de tiempo pasado, dice más: "No solamente he conocido y sentido su voz, mas ya lo veo estar que por entre las puertas mira, por las saeteras y por las rejas de mi casa". Estos son los regalos y graciosísimos juegos de los enamorados, que es como un jugar al tras ${ }^{270}$ con los niños: cuando ella lo ve por entre las puertas, él de presto ${ }^{271}$ se quita de allí, corre a mostrarse por las saeterillas de la casa; $y$, de allí siendo visto, se muda a las rejas y se asoma un poco, y asi de un lugar en ctro, $y$ en todos ella lo sigue y alcanza con la vista. $Y$ este mostrarse y asconderse ${ }^{272}$ se muestra bien en lo hebreo, que dice: $;$ Helo! Florece por las ventanas, por las rejas, que quiere decir que muestra los cabellos o muy poco de su persona, como las florecicas ${ }^{273}$ cuando comienzan a abrir, que muestran un poquito de sí. Esto es muy común cuando uno se asconde burlando de verlo el otro: "¡Ah! También te veo la cabeza, veo ahora los ojos por entre las puertas. ¡Oh! Ya se ha quitado. ¡Helo! ¡Helo! Alli por la ventana asoma". Y, como hemos dicho, estas cosas, aunque parecen niñerías, no lo son en los amantes, porque ellos estiman unas cosas de que los otros hacen poco caso, y las cosas en que otros se recrean o las precian [para] ellos son fastidiosas y de poca estima.

Está muy claro el sentido de estas palabras en lo que toca al espiritual Esposo, porque no es otro sino el presto socorro de Dios a los que ama, como lo fue en las palabras antes de estas, y que a Dios no le estorba dificultad ni otro impedimento a la presta venid?. Que, aunque yo esté allende el mar o en los más remotos lugares de la tierra, allá lo tengo de hallar muy presto en mis necesidades, como lo promete él mismo, diciendo: Con él estoy en las tribulaciones. Y lo que dice: Mirando por las rejas ${ }^{274}$, es la certidumbre de su socorro y cómo lo ve y siente la Esposa, que lo recibe. Y de esta manera se muestra Dios acá en la tierra, porque, por la capacidad del hombre mortal, no da clara muestra de su presencia, mas ${ }^{275}$ se muestra por los efectos que hace en los suyos, ayudándolos y favoreciéndolos de tal manera que pueden decir: "Yo lo veo asomar y mostrarse". Y así se mostraba Dios en Cristo, y se vía ${ }^{276}$ y coligía ${ }^{277}$ que estaba alli, detrás de aquellos impedimentos y velos de la carne humana, por las cosas maravillosas y excelentes palabras suyas, que muchos andaban diciendo: "Sí es él"; o: "No es éi". Mas los miembros de su Esposa, que eran los que con las juras de la fe le recibían por Esposo, bien le conocían y confesaban, el uno diciendo: El que después de mi vino primero fue

\footnotetext{
${ }^{270}$ Tras: juego de persecución. Relacionado con la siguiente acepción de la palabra Tras (1): trasero, asentaderas (DRAE, 6).

${ }^{271}$ De presto: prontamente, con presteza.

${ }^{272}$ Asconderse: esconderse.

${ }^{273}$ Florecicas: en el manuscrito encontramos floresicas.

${ }^{274}$ En el inanuscrito, salmo 90 (91). El titulo de este salmo es $A$ la protección divina.

${ }^{275}$ Mas: interpretabie como equivalente a sino u poro.

${ }^{276}$ Via: forma antıgua, por veia.

${ }^{277}$ Coligir: colegir.
} 
que yo ${ }^{278}$; y el otro: Tú eres Cristo, hijo de Dios ${ }^{274}$. De este socorro y ayuda de Dios, con qué es presto a sus amadores y con cuánta majestad viene y cuán encubierto por la grandeza de su divinidad, hizo David un elegantísimo salmo, el cual adelante se declarará andando el tiempo.

Hablóme el mi amado, diciendo: ¡Levántante, amiga mia, y vente! Ya pasó el invierno, la lluvia se retrajo, el tiempo de cantar es verido y en nuestra tierra se oyó la voz de la tortolilla; la higuera ha ya mostrado sus botones, las vides dieron su olor. ¡Levántate y vente, amiga mia!

Convida en este lugar el Esposo a la Esposa al gozo de sus amores. Y, porque él anda en el campo, el cual es un lugar muy aparejado para los enamorados, moviéndolos allí todas las cosas a mayor amor, donde no hay estorbo sino gran sosiego, y por ser la sazón del verano, que es tiempo fresco y apacible, muy aparejado para tratar amores; pide a la Esposa que se salga ya de su casa y se venga a vivir a donde él estuviere. Mas, porque se le haría grave la salida a una doncella no muy usada en esos trabajos, sino que solamente suele guardar una viña o entender en otros tales menesteres livianos, porque ${ }^{280}$ no le parezca pesado el salir de su casa a vivir en el campo, mitiga el Esposo y alivia su carga; lo uno con ponerle delante su amor, llamándola tantas veces: "¡Oh! Amiga mía, compañera mía"; y lo otro con mostrarle la belleza del campo y la buena templanza del tiempo y todas las otras cosas que a este caso favorecen y ayudan a los amores. Y, así, le dice: "Levántate de ahí donde estás en tu casa acostada (que aún lo estaba después del desmayo) y vente. No tengas temor a la salida, porque el tiempo está muy gracioso: el invierno, con sus vientos y fríos y aguas, que te podían fatigar, ya se fue. El verano es ya venido, y de esto todas las señales se han mostrado: los árboles están con gran belleza, comenzándose a vestir de flores y hojas; las aves entonan sus músicas y la tortolica, ave peregrina, que no invierna ${ }^{281}$ en nuestra tierra, ya es venida a eila; ya hemos oído cantar; y la higuera tiene sus restalloncicos ${ }^{282}$, que ya brotan; las vides tienen pámpanos y huelen a su flor. De manera que, por testimonio de todos los animales y plantas, nos es manifiesta la vida del verano: la sazón es fresca, el campo está hermoso; ahora es tiempo que tú salgas de tu casa y te vengas para mi. Todas las cosas favorecen tu venida y ayudan a nuestro amor, y parece que naturaleza nos adereza y adorna el aposento. Queriéndome tú y amándome mucho, sé que [te] holgarás de venir y que te holgarás mucho en el campo, donde trataremos más sin estorbo nuestres amores. Por eso, levániate, amiga mía, y vente".

Esta plática que aquí la Esposa dice haber oído al Esposo son las nuevas mensajerías de su venida cuando vino a celebrar las santísimas bodas en tiemıo de grandes vanidades, supersticiones y infidelidades. Tiempo era aquel de invierno, triste, frío y afligido, en el cual la Igiesia, solamente en su casa en la tierra de Israel escondida, no osaba salir ni publicarse a su buscar a su Esposo. Sabía bien quién él era, cuán amable, cuán bello, y deseaba juntarse con él;

\footnotetext{
${ }^{278}$ En el manuscrito San Juan, 1. Concretamente se trata de San Juan (1, 27-30). Además, puede encontrarse esta idea en San Mat:o (3, 11), San Marcos $(1,7)$, y San Lucas $(3,16)$.

${ }^{279}$ En el manuscrito San Mateo, 16. Concretamente se trata de San Mateo $(16,16)$. Además, puede encortrarse esta idea en San Marcos (8, 29), y San Lucas $(9,20)$

${ }^{280}$ Porque: valor final.

${ }^{281}$ Inviernar: invernar

${ }^{282}$ Restalloncicas: variante -en diminutivo- de retallo (2): nuevo tallo (DRAE).
} 
de esta privación procedían los desmayos y las congojas. Viene, pues, el Esposo a verla en la mayor necesidad. La llama que se salga ${ }^{283}$ al campo con él, que se entienda y salga a la anchura del mundo y deje los rincones de su casa. Porque toda aquella infidelidad; los espantos de los hombres; las lluvias y aguaceros de las innumerables tribulaciones que, por la carga de los pecados, sobre ella venían; tantas de las imposiciones que la cargaban sus manos para enlazarla en graves y diversas culpas; $y$ todas las otras adversidades con que estaba acorralada y arrimada, triste y perseguida la Esposa pasan y se van al tiempo de la venida de Cristo. Las flores de la predicación, de donde se ha de coger después fruto de santificación, ya se demuestran ${ }^{284}$; las viñas y higueras, de las cuales se ha de coger el fruto dulce para el gusto de los hombres y el vino de la verdadera, sara y sabrosa doctrina de la nueva ley, ya ha[n] comenzado a brotar y a dar su olor ${ }^{285}$.

Era entonces la predicación del bautismo y evangelio de penitencia y enmienda de vida, para que, en tan buena sazón y hermosa prixnavera, se celehrasen las sagradas bodas y se celebrase este casamiento, cuyas arras eran el reino de los cielos ${ }^{286}$. Este tan gracioso y apacible verano que sería con la huida del invierno a la venida del Esposo [lo había] profetizado Isaias, diciendo: Consolaos pueblos mios, dice el señor ${ }^{287}$. Pues de esta manera llamaba el Esposo a su Esposa universalmente en aquel tiempo y en este de ahora, y siempre llama en particular a cualquiera miembro de esta Esposa, prometiéndole su presencia y el gozo de sus amores y la unión verdadera consigo en santidad, justicia y verdad; avisándole de la ida del invierno, que es el temor y espanto de la conciencia, y de la lluvia de los pecados, los cuales todos se van huyendo con la venida del Esposo, y queda gran regocijo y bellísimo verano para celebración de las santas bodas.

Paloma mía, en las cuevas de la piedra y en los agujeros de la subida me muestra tu vista. Haz que yo oiga tu voz, porque tu voz es dulce y tu vista bella.

Declara ya el Esposo a la Esposa la condición de su amor y cómo se ha de haber con él ${ }^{288}$ en este oficio de amarlo, pues ya es tiempo [de] que se junten a vivir en uno, como arriba lo mostró; y, para darlo a entender, trae una bellísima semejanza de las palomas, cuya propiedad sabida $^{289}$, estará claro este lugar. Se han ${ }^{290}$ de tal manera las palomas en sui compañía que,

${ }^{283}$ La llama que se salga: construcción -aún viva en el habla popular- en la que hemos de suponer otra forma verhal, de lá que dependa la proposición que se salga. Se trata de un uso relativamente frecuente en nuestro texto. En determinados casos, no obstante, podrian proponerse otras interpretaciones (ver ncta 373)

${ }^{284}$ Se demuestran: se muestran.

${ }^{285}$ Esta idea se recoge, como sefiala el manuscrito en anotación marginal, en Carlas a los Romanos, 6. Concretamente se trata de Cartas a los Romanos $(6,21-22)$

${ }^{286}$ Esta idea se recoge, como señala el manuscrito en anotación marginal, en San Marcos, 1 y San Lucas, 5 . Concretamente se trata de San Marcos (1, 14-15) y San Lucas (4, 20-21).

${ }^{287}$ En el manuscrito, Isaias, 4. Esta idea se desarrolla durante todo el capitulo.

${ }^{288}$ Haberlo con uno: tratar con él, y especialmente disputar o contender con él (DRAE)

${ }^{289}$ Cuya propiedad sabida: construcción de participio absoluto.

${ }^{290}$ Haber: (prnl) portarse, proceder bien o mal (DRAE, II). 
desde que una vez se enamoran dos, macho y hembra, para vivir juntos, ya más ${ }^{291}$ deshacen la compañía hasta que el uno falta de en medio; y esto nace del natural amor que se toman. Y la paloma está muy obediente a todo el querer del palomo; tal que no le basta todo el amor y lealtad que de su naturaleza le tiene, sino que también sufre muchas riñas y importunos celos del marido. Porque esta ave es la que más muestras de celos da. Y, así, en viniendo él de fuera, luego hiere con el pico a su compañera y con la voz áspera da grandes indicios de sospecha; cercándola muy azorado y arrastrándola está; $y$, a todo esto, ella está muy' paciente, sin mostrarse áspera. Y estas aves, entre todos los animales brutos, muestran más claro el amor que se tienen ser de gran fuerza, así por el andar siempre juntos y guardarse lealtad el uno a! otro con gran simplicidad, como por los besos que se dan y los regalos que se hacen después de pasadas aquellas iras que los celos en el marido levantaban. Pues, de esta manera misma, notifica el Esposo a su Esposa en las palabras que ahora le dice que se han de ver ambos en el amor. Y, cuando arriba dijo compañera mia, ya comenzaba [a] apuntar esta semejanza, porque cuasi $^{292}$ en todas las lenguas la junta de las palomas se llama "compañía" y ellas se llaman "compañeras", y se suele decir "a esta paloma le falta el compañero".

"Pues venid acá, compañera mía -dice el Esposo-, que ya es tiempo [de] que juntemos esta tierna compañía. Sabed que yo soy palomo y vos habéis de ser paloma, y no de otro palomo, sino mía, paloma mía, amada mía, y así yo he de ser amado y compañero vuestro. Este amor ha de ser firme para siempre, ninguna cosa ha de bastar para deshacerlo o disminuirlo. Y, con todo eso, yo os tengo de pedir celos ${ }^{293}$. Y, porque, aunque hay muchas palomas en un lugar, cada cual vive por sí, ni ella sabe el nido ajeno ni el palomo extraño les quita el suyo; es razón que nosotros nos apartemos a nuestra poyatilla ${ }^{294}$ aparte. Nos ${ }^{295}$ es razón que vos andéis entre la gente y yo me esté en el campo. Si me queréis agradar, ha de ser a solas; si habéis de cantar conmigo, solo ha de ser. Por eso, veníos conmigo al campo, paloma mía. Aquí, en esta peña, hay unos agujeros muy aparejados para nuestra habitación; aquí hay unas cuevas en esta barranca alta; aquí mostradme vos, paloma mía, vuestra vista y aquí os oiga yo cantar, que aquí me agradáis y, en esta soledad, vuestra vista me es muy bella y vuestra voz suavísima. Finalmente aquí, en el campo, quiero que estéis conmigo y aquí me place (de) ${ }^{296}$ participar de vuestras gracias; porque soy palomo celoso y vos, paloma mía bella, no habéis de estar en casa, no en los regalos de la ciudad; ni quiero casa con vigas de cedro ni corredores de ciprés con que en denantes ${ }^{297}$ me convidábades ${ }^{298}$, ni otra delicadeza [que] suele dañar a la

\footnotetext{
${ }^{291}$ Ya más: jamás. Forma antigua, aún no evolucionada.

${ }^{292}$ Cuasi: casi.

${ }^{293}$ Pedir celos: hacer cargo a la persona amada de haber puesto su cariño en otra (DRAE).

${ }^{294}$ Poyata: vasar o anaquel que sirve para poner vasos y otras cosas (DRAE).

${ }^{295}$ Nos: probablemente se trate de un error: nos en lugar de no.

${ }^{296}$ (De): suprimimos la preposición en base a los usos modernos, dado que participar es el sujeto de place, y, consecuentemente, no está necesitado de ella.

${ }^{297}$ Denantes: antes. Forma desusada.

${ }^{298}$ Convidábades: forma arcaica de pretérito imperfecto de indicativo.
} 
honestidad, sino ura cueva, una ventanilla de estas de las peñas y barrancas, porque en esta rusticidad se conserva más lealtad del amor".

De la letra así alumbrada queda claro el sentido que al espíritu pertenece; porque, habiendo el Esposo del cielo de poner su amor en la Esposa, le da a entender su condición: cómo es palomo que mucho ama y mucho quiere ser amado; tanto que él mismo, declarándolo en otra parte, dice: "De todo tu corazón, de toda iu voluntad, de todo tu pensamiento y ánimo, que no ames a otro más, ni desees amar a otro más, ni te pase aun por la imaginación ${ }^{299}$, porque yo sny celoso palomo, como por mi mandado lo profetizó el profeta $\mathrm{Nahum}^{300}$ y como en todos los profetas se hal!ará, que demandan estos celos de parte mía y acusan de adulterio a mi amiga la sinagoga que entonces era mi amada. Así que sabed, Esposa mía, que no consiento que con mis amores se tejan otros, sino yo solo quiero ser amado, no otro dios vano de los gentiles, no vuestra codicia y no vuestros contentos ni vuestra gloria ni ninguna otra cosa fuera de $\mathrm{mi}^{301}$; y porque ${ }^{302}$ la simplicidad de este amor y fe se conseva más en la cruz que en los regalos y delicadezas del mundo".

Quiere el Esposo que su Esposa salga de su casa y se vaya a las cuevas de las peñas y de las barrancas, que es tanto como apartarla de los regalos y apopamientos ${ }^{303}$ de la carne y ponerla en una vida solitaria, más rústica y más apartada de escándalo; y esta no se entiende que ha de ser por fuerza vida del campo ni cuevas de peñas, sino un género de vida tal cual debe hacer el que está en el campo y en las cuevas: una vida apartada de las perdiciones del nundo, de las soberbias y ambiciones, de las avaricias y desenfrenados apititos ${ }^{304} 305$. Demanda que a solo su palcmo muestre su paloma gentil la vista de su conciencia bella, sana, simple y graciosa; no pretenda mostrar su hermosura al mundo ni detener el $^{306}$ vulgo con la duizura de su canto, sino todo esto lo haga escondido, quiero decir, que no lo haga sino por agradar a Dios, sin ningún otro respeto humano, y por contentar al que ve escondido ${ }^{307}$.

En la letra dice: En las cavernas de la piedra y en los agujeros de la escala. Y es repetición de seña, y en decir escala significa cualquier barranco o lugar alto, y también algunos paredones viejos que hay en el campo, en los cuales suele haber algunos agujeros que [utilizaban] los albañiles, mechinales donde se armaban los andamios cuando se edificaba, y en estos mechinales de las paredes desiertas suelen las palomas hacer sus nidos.

\footnotetext{
${ }^{299}$ En el manuscrito, Deuteronomio, 6. Concretamente se trata de Deuteronomio $(6,4-5)$.

${ }^{300}$ En el menuscrito, Nahum, 1. Concretamente se trata de Nahum $(1,1-2)$.

${ }^{301}$ En el manuscrito, Jeremias, 2. Esta idea se desarrolla a lo largo de todo el capitulo.

${ }^{302} Y$ porque: esta proposición parece desligada sintácticamente de lo anterior, pues no está nada claro con qué pueda coordinarse

${ }^{303}$ Apopamientos: blandicies (sentido contextual, no registrado)

${ }^{304}$ Apititos: apetito.

${ }^{305}$ Esta idea se recoge, como señala el manuscrito en anotación marginal, en San Juan, 2. La idea se desarrolla a lo largo de todo el capitulo.

${ }^{306}$ El: al.

${ }^{307}$ En et manuscrito, San Mateo, 6. Concretamente se trata de San Mateo (6, 1-4).
} 
Tomad las raposas, las raposas pequeñas que destruyen las viñas. $Y$ nuestra viña ha mostrado su agraz. Mi amado para mi y yo para él, el ctial apacienta entre las violetas.

Llamada la Esposa a la compañia de su Esposo y teniendo entendido el amor que le tiene, se pone muy ufana y regalada, y viene en este lugar a ser movida de un afecto común a los regalados en teniendo delante de sí a quien los ama y regala. Declararlo hemos en una semejanza. Cuando una madre está ausente o $\mathrm{la}^{308}$ ha estado de un niño su hijo, en viniendo luego, pregunta por él y lo llama y lo abraza, mostrándole aquella terneza de amor que le tiene. Lo primero que él hace es quejarse de quien lo ha ofendido en ausencia de su madre, porque el deseo que tiene de vengarse le fuerza a que pida socorro de quien puede vengarlo. Lo mismo hace una Esposa -o mujer casada- que mucho ama a su marido, el cual ${ }^{309}$ ha tenido algún espacio de tiempo apartado de sí; luego se le regala quejándose de las desgracias que en su ausencia le han acaecido.

Este afecto muestra aquí la enamorada y tierna Esposa y regalada con el llamar de su Esposo y con lo demás que le dijo. Se queja de la cosa que más la ofende, y es [que] ${ }^{310}$, como ella tenía una viña, que arriba bemos visto, la cual preciaba mucho por ser suya y de su Esposo, y veía que las vides estaban encierne y que daba ya a quedar limpio el agraz, tiene gran temor [de] que las raposas se la echen a perder. Y, quejándose de la mala casta dañadora, pide socorro al Esposo y a los pastores, sus compañeros, diciendo: Cazadnos las raposas, las raposas pequeñas. Guarda bien la propiedad de naturaleza, porque, cuando las viñas están en agraz y comienzan a madurar, entonces las raposas de las camadas se crían y estas hacen después mucho daño a las viñas, porque son muchas y van juntas; como por su poca fuerza no se atreven a hacer salto $0^{311}$ en el ga[na]do ni en las gallinas ni en las otras cosas que los raposos viejos cazan y destruyen, se van a las viñas, donde hay menos concurso de hombres y perros y ellos son menos vistos ${ }^{312}$ por la espesura de las hojas y pámpanos, y allí hacen mucho daño. Por tanto, ruega la Esposa que les busquen las camadas y las tomen y maten mientras son aún pequeñas, porque será más fácil así $(\mathrm{de})^{3 / 3}$ deshuirlas ${ }^{3 / 4}$, que no esperando a que crezcan. Y, declarándose, dice las raposas pequeñas; quiere decir: "Ahora que son pequeñas, que es buen tiempo; ahora đque las viñas están en agraz, antes que crezcan ellas y maduren las uvas".

Vino a muy buen tiempo esta queja en la Esposa, porque, como hemos dicho, en tal tiempo se sielen quejar y pedir venganza contra quien les ofende los que tiernamente aman y sienten muestras del amor que se les tiene. $Y$ así son todos los otros lugares de este libro, donde parece

\footnotetext{
${ }^{308} \mathrm{La}$ : parece un claro error: la en lugar de $l o$.

${ }^{309}$ El cual: al cucl.

${ }^{310}$ [Que]: realizamos esta adición para intentar salvar el anacoluto. La proposición que sigue (como ella...) podria considerarse sujeto (cómo ella...) pero careceria de sentido que la ofendiera ver sus viñas en cierne. Considerado esto, estimamos más adecuado considerar como sujeto tiene un gran temor..., para lo cual resulta necesar io la adición de estæ conjunción. Nos basamos, además, de nuevo en el pasaje análogo del Comentario según la letra.

${ }^{311}$ Salto: acción y efecto de asaltar (DRAE, 8).

${ }^{312}$ Ellos... vista: deberia ir en femenino, pues se refiere a las raposas.

${ }^{313}$ (De): suprimimos la preposición, innecesaria según los usos actuales, pues el infinitivo al que acompaña realiza la función de sujeto.

${ }^{314}$ Deshuirlas: destruirlas.
} 
no tener dependencie ${ }^{315}$ las unas palabras de las otras; que, si se considera y entiende el sentido [del afecto] $]^{316}$, lo tiene muy grande $\mathrm{e}^{3: 7}$ muy trabado. Porque estos libros en que se tratan pasiones de amor y dolor, ira y enojo, y otros tales, llevan sus razonamientos y las ligaduras de ellos en el afecto, no en las palabras, y esto es menester advertirse y amonestarse muchas veces; $\mathrm{y}$ con esta advertencia se entenderán mejor los libros Job, llantos de Jeremías ${ }^{318}$, y muchos Salmos de David.

Son las vulpejas ${ }^{319}$ de quien[es $]^{320}$ en este lugar la Esposa se queja los malos y perversos hombres, que, muy avisados ${ }^{321}$ para sus intereses, destruyen y gastan todo lo bueno de la viña de Dios con artes malas y enganio[s] sutiles, con apariencias honestas y muestras del buen ceio. $\mathrm{Y}$ esto suelen significar las raposas en la Sagrada Escritura cuando se pone en sentido de parábola, como es en aquel lugar: Decid a esa raposa cómo yo lanzo los demonios, etc ${ }^{322}$. Esto decía Cristo por Herodes, tirano que, por su particular interés y ambición, toda la virtud y justicia pervertía. Manda, pues, la Esposa que le destruyan las tales raposillas. Estos [son los] autores de escándalos y disensiones y herejías, finalmente, los que corrompen y destruyen el fruto de las viñas, que no son para ${ }^{323}$ otra cosa que para levantar cismas y sectas de perdición en el mundo, movidos por su propia ambición, que no los deja reposar hasta que desbaraten y dañen todo cuanto hay en el mundo. Y estos son tan perdidos y endiablados por este espíritu de propia honra que los aguija que, en cualquiera ley y seligión que estuviesen, harian lo mismo que hacen en la ley de Dios, sembrando escándalos y cizañas para disparatar lo antiguo e imponer e ingerir cosas que a su apetito agradasen; porque no sufren que otro sea nombrado ni otro tenga nombre de gloria en el mundo sino ellos. Y por eso dice la Esposa: las que destruyen las viñas, que quiere decir que están con ánimo de destruírlas todas. Y luego añade: "Porque no destruyan la mía, que está nuestra viña en agraz". Y estas raposas demanda la Esposa que sean cazadas y destruidas cuando pequeñas ${ }^{324}$, antes que crezcan y tomen fuerza, porque es fácil de atajar el mal en su principio.

\footnotetext{
${ }^{315}$ Parece no tener dependencia: según los usos modernos, podria pensarse que el sujeto de parece es las unas palabras, y qus, por tanto, el verbo deberia ir en plural. Sin embargo, según la lengua de nuestro texto (ver nota 6), esta construcción no es extraña, pues el sujeto es la proposición completiva de infinitivo.

${ }^{316}$ [Del afecto]: nos parece importante esta adición para completar el sentido de la frase. Nos basamos de nuevo en el Comentario segín la letra.

${ }^{317} E$ : ya indicamos al comienzo (ver nota 1) que ibamos a respetar la forma original de las conjunciones. Encontramos aqui la forma $e$, pero no en el uso moderno -enfocado a evitar la cacofonia-, sino en un uso claramente arcaico, en la evolución de la forma latina et.

${ }^{318}$ Jeremias: en el manuscrito, encontramos, normalmente, Hieremias. En algunos casos, aparece abreviado $\mathrm{en}$ la forma Hiemias.

${ }^{319}$ Vulpeja: zorra.

${ }^{320}$ Quien[es]: no es habitual, según los usos actuales, utilizar esta forma para referirse a animales. Corregimos, además, la concordancia.

${ }^{321}$ Avisado: prudente, discreto, sagaz (DRAE, 2)

${ }^{322}$ En el manuscrito, San Lucas, 13. Concretamente se trata de San Lucas $(13,31-32)$

${ }^{323}$ No son para: se trata de un uso análogo al demoninado en sintaxis latina dativo de finalidad o efecto, una de cuyas construcciones tipicas se da con el verbo sum, transmitiendo la idea de "servir de", que encaja perfectamente en este cortexto.

${ }^{324}$ Cuando pequeñas: cuando son pequeñas. Construcción -aún común en nuestros dias- con elipsis del verbo ser.
} 
Después de esto, ia Esposa, regocijada grandemente con su Esposo y respondiendo al amor que le mostró, dice: Mi amado para mi y yo para él, dando a entender que son dos desposados muy conformes y para en uno ${ }^{325}$, y de tal suerte que ni ella ha de amar a otro, ni él a otra sino a su Esposa. Como si dijese: "De un mismo querer y de una misma voluntad sonios, de un mismo amor estamos encendidos, y estoy muy bien con solo él, sin otra cosa que desear pueda, porque êl también me quiere a ni sola"; y en esto [alude] ${ }^{326}$ a la semejanza de las palomas de arriba, dando a entender que ella hará buena compañía con su Esposo.

El cual pasta entre las violetas. Estas postreras son también palabras enamorades, porque los amantes en sus razonamientos usan mucho de vocablos de rosas y fiores para dar a entender la gracia y suavidad de sus amores. Y, así, aquí quiere decir: "Yo soy Esposa de aquel bello pastor que pasta entre las violetas, porque su ganado y todas sus cosas son muy extrañas de los otros pastores: el ganado de los otros pace en hierbas, y el suyo en rosas, flores, violetas y clavellinas y todos los pastos graciosos".

El espiritu de esta letra está claro, y no hay por qué detenernos en él, salvo que en decir que "el Esposo apacienta su ganado entre las flores" da a entender la suavidad y gracia de la doctrina con que el ganado de Dios se mantiene; el de los otros pastores vanos con espinas y abrojos trata.

Hasta que sople el dia y huyan las sombras. Tornándote, parezcas, amado mio, a una cabra, a un ciervecito sobre los montes de Betel.

Son las mujeres temerosas de noche y por esc están mal a sus solas, teniendo necesidad de quien las ampare. Y, si en algún tiempo desean tener consigo a sus maridos, esposos, padres 0 hermanos, es principalmente en la noche; y parece que aquel temor que tienen les aumenta el amor cən aquellos de quien se valen. Viniendo, pues, ya la tarde, desea mucho la Esposa que su Esposo viniese a estar con ella la noche por esta causa; o que estuviese el Esposo cerca, de manera que la pudiese oír; o estuviese lejos y ella le hablase en ausencia, como es común costumbre.

Dice de . ta manera: Hasta que sople el día y las sombras huyan. En sste rodeo de palabras declara la mañana, porque, cuando amanece, siempre viene un airecico más fresco que el que ha bullido en la noche. $Y$ esto es natural, y nosotros a este aire llamamos "fresco", y también a la mañana. [Dice pues la Esposa]: "Las tinieblas y sombras de la noche huyeron con la presencia del sol, autor del día. Vente, pues, Esposo esta noche a estar conmigo hasta que amanezca, porque $e^{327}$ yo pueda pasar la noche en compañía y amparada de quien tanto amo". Porque e ${ }^{328}$ amante todo el tiempo que tarda en gozar de lo que desea le parece más largo de lo que es y el esperar le da gran pena, dice: "Vente, amigo, a muy gran priesa y con gran ligereza

\footnotetext{
${ }^{325}$ Ser para en uno: locución, con que expressamos, que dos personas son mui conformes, y parecidas en las costumbres, y modales, $y$ que se convendran facilmente en qualquiera especie. Usase regularmente hablando de los casamientos (D. Aut.)

${ }^{326}$ [Alude]: parece clara la falla en la oración, necesitada de un verbo.

${ }^{327}$ Porque : construcción de srntido claramente final.

${ }^{328}$ El: al.
} 
cual tú la sueles tener en los pies, que no parecías ${ }^{329}$ sino una cabra montesa o un ciervecito de los del monte de Betel, donde hay muchos y muy ligeros".

La universal Esposa, que era entonces la Iglesia de Israel, estaba entonces en tinieblas y sombra, por no ser aún venida la luz clara de la manifiesta verdad y Evangélica Doctrina. Deinanda por esto la Esposa que en aquel tiempo no la dejase, $\operatorname{mas}^{330}$ siempre la favoreciese y en esto fuese muy presto cuando lo hubiese menester -y así lo hacía el Esposo-, y esto hasta que huyesen las sombras de la noche en que ella estaba y amaneciese el día, en que ahora estamos los del Nuevo Testamento que lo queremos recibir; estamos en la claridad del día, doncie no hay temor ni recelo sino manifiesta luz de fe y claro conocimiento de Dios, que se nos vino a mostrar y declarar, como lo preveía aquel gran testigo de los divinos secretos, diciendo: Vosotros sois hijos de la luz y del dia ${ }^{331}$. En particular, cualquier Esposa que está en la vida presente entre tantos temores y tribulaciones, y en la cruz, desea la asistencia y favor del Esposo hasta que venga el día de la gloria y claridad que Cristo da a los suyos, donde claramente conozca el sumo bien. Así [vemos] cómo él es, como lo dice el Apóstol, o cómo debía estar en las tribulaciones de la noche de esta vida humana aquella Esposa particular, cuando por sí y en nombre de otros decía: Mi alina, señor, te desea en la noche ${ }^{332}$.

\section{CAPÍTULO [IIII $^{333}$}

Sobre mi cama en las noches busqué al que ama mi alma; busquélo, mas no lo hallé. Levantarme he $y$ dare $e^{334}$ vuelta por toda la ciudad, por los barrios y las plazas, y buscaré al que ama mi alma. Encontráronme las guardas que andan por la ciudad. Preguntéles: ¿Por ventura vistes ${ }^{335}$ ai que ama mi lma? Como un poco los hubiese ya pasado, hallé al que ama mi alma. Tenerlo he y no me descuidaré con ${ }^{336}$ él hasta meterlo en casa de mi madre y en la recámara de la que me parió. Ruégoos, hijas de Jerusalén, por las cabras y por las ciervas del campo, no despertéis ni hagáis levantar al amado hasta que el quiera. ¿Quién es esta que sube del desierto como unas palmas de humo perfumadas con mirra y incienso, $y$ con todos los polvos del maestro de olores? Mirad en torno de la cama que tiene Salomón; sesenta valientes

\footnotetext{
${ }^{329}$ Parecias: esta forma de pretérito imperfecto de indicativo rompe ccn el sentido de la oración, pues se está tratando de una acción no realizada.

${ }^{330}$ Mas: equivalente a sino.

${ }^{331}$ Alusión bíblica sin anotación al margen en el manuscrito. I Tesalonicenses $(5,5)$.

${ }^{332}$ En el manuscrito, Isaias, 26 . Concretamente se trata de Isaias, $(26,9)$.

${ }^{333}$ [III]. realizamos esta la adición y suprimimos lo que hemos encontrado en el manuscrito $\left(3^{\circ}\right)$ en un intento de homogeneizar los títulos de los capitulos.

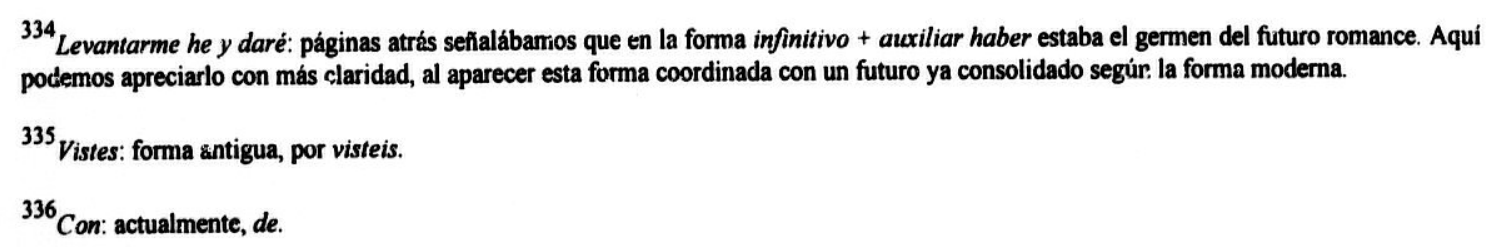


están de los valientes de Israel. Todos ellos empuñada la espada, experimentados en guerra; cada uno su espada sobre su musio por el temor de las noches. Una tienda hizo para él el rey Salomón de los árboles del Libano. Sus columnas hizo de plata y su techo de oro; su cobertura de purrpura. En medio de él asentó el amor de las hijas de Jerusalén. Salid y ved, hijas de Sión, al rey Salomón con la corona con que le coronó su madre el día de su desposorio y el día del regocijo de su corazón.

\section{[EXPOSICIÓN]}

Sobre mi cama en las noches busqué al que mi alma ama; busquélo y no lo hallé.

En el fin del capítulo que ahora dejamos, la Esposa llama a su Esposo que viniese a tener la noche con ella, la cual se debió de acostar en su cama después de venido el Esposo, pensando $\mathrm{de}^{337}$ esperarlo allí y que él iría, después de ella acostarse en la cama, con ella; y con esta creencia se durmió. Que así parece por lo que ahora en este principio dice, que, en despertando, busca por la cama si era venido su amado y si estaba allí con ella; y, no hallándole, salta de la cama y piensa que se le haya ido a pasear por el pueblo, y determina $(d e)^{338}$ buscarlo. $Y$, andándolo buscando, [se] encuentra con la ronda -o guarda de la ciudad-, que a tales horas suele(n) ${ }^{339}$ andar, y les pregunta si le han visto; $y$, como no le dan nuevas de él, los deja. Y, de ahí a un poco dice que lo halló y, en hallándolo, asió de é $\left.\right|^{340}$ y no lo dejará hasta meterlo en la casa de su madre y en la camara de la que la parió. Esta es la letra de estos amores. Y es muy común esto a las desposadas que bien aman a sus esposos, que, en faltándoles de noche de casa, les viene mala sospecina, o que no las aman o que aman a otras. $\mathrm{Y}$ algunas [hay ] $]^{341}$ que les da tanto atrevimiento esta pasión que les hace irlos a buscar. [Y más] de un ejemplo se ve cada día de esto.

Mas el espíritu de estas palabras es que la Esposa, estando en la noche de las tinieblas, de las que ya arriba dijimos, antes que amaneciese el día de la luz, que todo hombre procuraba a Dios, su Esposa [estaba] ${ }^{342}$ en su cama, que quiere decir en su sabiduría humana y en las propias imaginaciones e invenciones de santidad, en las cuales ella se reposaba y holgaba como en cama propia; y no lo halló alli a su Esposo, porque nunca él se halla en las obras y ordenaciones tenebrosas de la invención humana, donde no hay luz de la palabra divina, y si ${ }^{343}$

\footnotetext{
${ }^{337}$ Pensando: to habitual actualmente seria pensando en o simpiemente pensando.

${ }^{338}(\mathrm{De})$ : suprimimos la preposición por tratarse de un verbo transitivo, no necesitado de ella según los usos actuales. Por otra parte, hay que decir que es común actualmente la forma pronominal: determinarse $a$.

${ }^{339}$ Suele(n): en plural, se trata de una concordancia ad sensum, al estar integrada la ronda por un numero plural de persoras.

${ }^{340}$ Asió de èl: actualmente resulta más habitual en forma pronominal: asirse de.

341 [Hay]: completamos aqui y en la linea siguiente a partir del Comentario según la letra.

342 [Estaba]: no está nada clara la ligazón sintáctica de esta oración. Creemos el texto mutilado, y es por ello por lo que hemos realizado esta adición, aunque, aun asi, la sintaxis sigue sin ser fluida. En cualquier caso, en este punto (su Esposa) se retoma el sujeto ya enunciado dos lineas más arriba (la Esposa).

\$43 Y si: léase sino, por el contrario.
} 
lo que se hace es contra la Divina Escritura, como éi mismo lo avisa, diciendo: No hagáis cada uno lo que agradare a vuestros ojos, mas ${ }^{344}$ lo que te ha mandado, aquello solamente harás al Señor; ni añadirás cosa ni quitarás ${ }^{345}$.

Así que, no hallando a su Esposo en este contento, razón y sabiduría suya[s] $]^{346}$, determina $\mathrm{de}^{347}$ levantarse de allí y lo anda a buscar. Pregunta a los guardas aquellos, que tenían por oficio (de) ${ }^{348}$ guardar y asegurar [a] la gente. Como eran los maestros y enseñadores de la sabiduría, estos dice que andaban rondando y guardando la ciıdad en el tiempo de la ignorancia. No le supieron dar nuevas de él. Y luego, de allí a un poco, lo halló, porque después él mismo se vino a hacer eiıcontradizo, que ni la Esposa por sí ni por la guía de los guardas atinara adónde ${ }^{349}$ estaba si no fuera por el conocimiento de la verdadeta ley suya, en la cual sola está y allí lo ha(n) ${ }^{350}$ de haliır quien porfiare en buscarlo ansiado del amor suyo, como andaba la Esposa. Pues, después que la Esposi lo halló -que se halla en la fe y guarc̉a de su ley, como lo testifica San Pablo a Timoteo, avisándole [de] que ei cáninc de la salud está en la observancia de la ley por la fe en Cristo-, dice que no lo tiene de dejar, sino asirlo y tenerlo muy bien y, por vía de la predicación, de la oración y del loor de su Esposo, meterlo en casa de su madre ${ }^{351}$, que es la congregación de los que no nan recibido la verdaciera doctrina, entre los cuales había nacido y criádose la Esposa, porque del pueblo fiel fue sacada y escogida la Esposa y fiel Iglesia de Dios. Esto mismo cuadra a cualquiera alma particular enamorada, que, si quiere hallar a su Esposo, ha de dejarse a sí y a sus contentos y a sus vanas y escusadas invenciones, y huir de las guías, que son ciegas, que no atinan con el Esposo. Y luego, pasando de esto, lo hallará, al cual abrace y tenga consigo no descuidándose; y enseñarlo ha a sus hermanos, y así lo meterá en casa de su madre.

En la letra dice: En la casa de mi madre y en la cámara de la que me parió. Es razón doblada en diversas palabras; sigue el uso hebreo.

Ruégoos, hijas de Jerusalén, por las cabras y las ciervas del campo, que no despertéis ni hagáis levantar al amor hasta que él quiera.

Después que el Esposo entra en la casa y cámara de su Esposa y de la madre de ella, parece que se durmió, cosa muy natural a uno que ha andado lo más de la nocne paseando, como hemos visto. Y ella, muy alegre de verlo dormido y reposado en su casa, ruega y conjura a las vecinas doncellas que no lo despierten. Y en la conjuración no hay más que declarar que lo de

\footnotetext{
${ }^{344}$ Mas: equivalente a sino.

${ }^{345}$ Fn el manuscrito, Deuteronomio, 12. Concretamente se trata de Deuteronomio $(12,8)$

${ }^{346}$ Suya[s]: concuerda, en singular, únicamente con el más cercano de los tres sustantivos a los que se refiere.

${ }^{347}(\mathrm{De})$ : ver nota 3.35

${ }^{348}$ (De): suprimimos la preposición por tratarse de un verbo transitivo, no necesitado de ella según los usos actuales.

349 Adónde: no es inusual cr: este texto el uso de adónde y adonde en lugar de dónde y donde. En este caso, no obstante, parece justificable, entendiéndose en el sentido de hacia dónde se encontraba.

${ }^{350} \mathrm{Ha}(\mathrm{n})$ : suprimimos el morferna de plural para hacer concordar a $\epsilon$ ste verbo con sa sujeto, que aparece en singular.

${ }^{351}$ Esta idea se recoge, como señala el manuscrito en anotación marginal, en ll Carta a Timoteo. Concretamenie, se trata de Il Carta a Timoteo $(4,6)$.
} 
arriba, salvo que dice la letra: No hagáis levantor al amor. El amor tanto quiere decir como "aquel que yo amo", que muy usado es en todas las lenguas este trueco de vocablos, diciendo "la maldad" por "el malo", "la belleza" por "lo bello", y "el amor" por "lo que yo amo". Y la causa es porque el amor quiere decir "aquello que me mueve a amar a otro".

No tiene cuerpo por sí ni persona distin ${ }^{+}$del mismo amado, sino allí está, en aquella cosa que incita mi voluntad; y por eso unos dicen que está en ' $s$ ujos de su señora, otros en la gracia de su cantar, otros en otras cosas, según lo que les pareció más bello en quien aman al tiempo que se enamoraron.

Viniendo al espíritu, decimos que ei divino Esposo tuvo por bien (de $)^{352}$ entrar en casa de su Esposa y de la madre de ella, porque él tiene dada su palabra de esto, diciendo: Si alguno me abriere, entraré a él y cenaré con él, etc. No es otra cosa este cenar sino perfecta comunicación, como hombres que han de vivir juntos y comer a una mesa. Entrando dentro, el Esposo duerme y reposa y está muy quieto, mas hay peligro [de] que las vecinas almas y compañeras de la Esposa no le turben el sueño y reposo con sus malas obras, bullicios, revueltas y alborotos mundanos, los cuales hacen despertar a su Esposs rder el sueño y reposo que en casa de la Esposa había de tener. Por tanto, con mucho cuidacio ruega la Esposa que no le rompan el sueño; antes, se lo guarden viviendo quieta y sosegadamente en vida virtuosa y conforine a la paz de Cristo.

¿Quién es esta que sube del desierto como palmas de humo perfumadas con mirra y incienso y con todos los polvos del ungüentario?

En este lugar, la Esposa cuenta relatando la admiración de las gentes vecinas, que, viéndola venir del campo alguna vez, donde estaba ya con su Esposo, se espantaban de ver tan belia y graciosa cosa. Y, así, las introduce preguntando con gran maravilla: "¿Quién es esta que vier. del campo?" Porque esta égloga -o canción pastoril- se representa en Jerusalén, que es ciudad alta. Dice la letra: "¿Quién es esta que sube del campo tan bella y tan graciosa y tan suave como una palma de humo que se produce de mirra encendida y incienso, con todas las demás olorosas cosas que un tendero de perfumes suele tener? Así viene esta graciosa, y tal suavidad da ce sí como si de todos los olores se hiciese una confección grande y se pusiese al fuego, que daría suavidad de sí".

En la letra dice: Una palma de humo. La palma sube muy alta; el pie de ella sigue muy derecho y no muy grueso, mas arriba hace gran copa. Esta figura remeda el humo que sale de los pebites ${ }^{353}$ y perfumes, que sube alto y un poco derecho, va junto y espeso, y hace uno como $^{354}$ pie o mástil poco más ancho, que es donde nace; dcspués que está alto, se esparce y hace una como copa de palma de humo oloroso, como acá decimos "un hilo de agua" por la semejanza que tiene la poca agua corriente con el hilo. Después que la Esposa tiene más estrecha conversación con su Esposo, se espantan las gentes de ver la belleza y gracia suya, y verla venir con tanto aumento y que crece tanto hacia el cielo como una palma de humo de

\footnotetext{
${ }^{352}(\mathrm{De})$ : suprimimos la preposición por tratarse de un verbo transitivo, no necesitado de ella según los usos actuales.

${ }^{353}$ Pebite: pebete (1): pasta hecha con polvos aromáticos, regularmente en figura de varilla, que encendida exhala un humo muy fragante (DRAE, 1)

${ }^{354}$ Hace uno como: hace como un.
} 
olorosa mezcla, el cual humo nace y se levanta de las buenas obras y perfección de virtudes de ella, que son entendidas por la mirra y por todos los demás perfumes que aquí dice.

Mirad en derredor de la cama que tiene Salomón; sesenta valientes están de los valientes de Israel. Toda empuñada su espada, hombres expertos en guerra; cada uno sobre su muslo su espada por el temor de las noches.

Habla en este lugar el Esposo manifestando sus riquezas, su poder, gentileza y todo lo demás, declarando también su nombre, el cual hasta ahora había callado y encubierto debajo de persona pastoril. Ahora se muestra ser Salomón y habla de sí como de tercera persona, que en lugar de decir: "Yo, que soy Salomón, tengo en derredor de mi cama sesenta hombres valientes", etc.; dice: "Salomón tiene en derredor de su cama sesenta valientes". Y este uso de trocar las personas unas por otras es muy común en la Sagrada Escritura, como es en aquel lugar: ¡Eh! Vamos a Jerusalén; y el hijo, como si dijera: ¿He yo ser crucificado? etc. ${ }^{355}$; y en otros muchos lugares se ha!la semejante manera de hablar.

Queriendo el Esposo en este lugar manifestar a su Esposa y a todas las gentes la seguridad, paz y sosiego que su Esposa tiene con él en el tiempo que ambos están juntos, dice que, aunque ella esté dormida, estando con él puede estar muy descuidada y reposada, sin temor ninguno de los espantos, daños, robos y peligros que suelen acontecer de noche; porque él tiene puesta muy buena guarda en torno de su cama, donde hay sesenta fuertes y valientes hombres, escogidos entre todos los valientes guerreros de Israel. Tanto que por eso replica ${ }^{356}$ su valentía mostrando que por fuerza ni por grado ni por amenazas ni dádivas pueden ser vencidos o corrompidos para que dejen entrar a quien venga a hacer daño. Del todo son valientes y fuertes hombres, ya experimentados en guerra y muy apercibidos, porque tienen sus espadas ceñidas, que cuelgan sobre sus costados hasta encima del nuslo, conforme al uso oriental de ceñir espada; siempre tienen empuñada la espada porque ${ }^{35 ?}$ no haya dilación en echar mano al tiempc de la necesidad. De manera que, con una guarda tan fuerte y tan fiel, muy segura puede dormir la Esposa en la cama de Salomón, su Esposo.

En muchas maneras Salomón, rey de Israel, representó la person: del divino rey autor de paz, Cristo; y, así, en este desposorio que aquí celebra, lo representó y prefiguró desposado con la sagrada Esposa, la Iglesia. Y este divino Esposo da ahora a entender cuán segura debe estar su Esposa en su abrazo y en su tálamo, donde goza de su Esposo; porque él, como gran rey, tiene en su servicio muchos hombres valientes, muy sabios en la doctrina de Dios, muy instruidos en la batalla espiritual de las sagradas disputas. Y estos no son de los valientes del mundo, ni armados de la sofística ${ }^{358}$ ciencia de él, sino de la doctrina de la ley de Israel, que quiere decir la ley que Dios tiene dada a su particular pueblo, cual es ahora el Cristiano. Y estos están armados y muy puestos a punto para pelear o defender la cama del Esposo, que es

\footnotetext{
${ }^{355}$ Alusión bíblica sin anotación al margen en el manuscrito. San Mateo (20, 18-20), San Marcos (10, 33-34), y San Lucas (18, 31-33).

${ }^{356}$ Replicar: repetir lo que se ha dicho (DK.4E, 3). Se trata de una acepción ya desusada.

${ }^{357}$ Porque: sentido final.

${ }^{358}$ Sofistico: aparente, fingido con sutileza (DRAE).
} 
aquella paz y amplicidad ${ }^{359}$ cristiana[s] ${ }^{360}$ donde reposa la Esposa con su Esposo; y para esto tienen aparejados los cuchillos, que son la ley y doctrina de Dios, como lo declara el Apóstol, diciendo: Tomad el cuchillo del espiritu, que es la palabra de Dios. Y de estos fuertes hombres armados con los cuchillos espirituales de la Divina Doctrina, que habian de pelear por el Esposo y por la defensión ${ }^{361}$ de su cama, cortando y destrozando todo el poder, justicia y sabiduría del mundo, profetiza el salmista, diciendo: Gozarse han los santos en alegria, alegrarse han en sus cámaras, los gozos de Dios en sus garganias, y tendrán espadas de dos filos en sus manos ${ }^{362}$. De manera que, con estas armas de los maestros principales, hombres de santidad y doctrina que Dios tiene en su servicio, será defendido su lecho de los temores que los príncipes y rectores de las tinieblas suelen poner y estará cierta [de] que nunca la desbaraten de su paz y sosiego como $^{363}$ ella esté durmiendo en la cama de su Esposo.

Donde dice en la letra sesenta valientes quiere decir "muy muchos", tomando el número cierto por otro mayor que no tiene término conocido, como lo suele usar la escritura [hebrea] y muchas otras lenguas.

Un pabellón hizo para si Salomón de los árboles del Libano. Sus columnas hizo de plata y su techo de oro; su cobertura de púrpura. En medio de él asentó el amor de las hijas de Jerusalén.

Va mostrando todavía el Esposo, después de declarado su nombre, el poder y riquezas suyas, su saber y buen concierto, y cómo todo esto lo emplea en servicio de sus amores, para que su Esposa entienda con cuánta razón lo debe amar. Y, para dar a entender todo esto, describe una tienda -o pabellón- que ha hecho, la cual es muy rica en los materiales y maravillosa de ver por su acertado y gracioso artificio. Y dice que él ha hecho una tienda para recogerse y holgarse en el campo, donde esta pastoril canción parece que se representa, cuyas columnas son de plata de muy linda hechura y proporción, y el techo que sobre ellas se sustenta es de oro fino, y la coburtura de las vigas de púrpura color, que era el más preciado de los antiguos.

Dice luego: En medio de él asentó al amor de las hijas de Jerusalén. En el hebreo parece decir: "En medio de él, abrasado por las hijas de Jerusalén". Y, así, tiene muy gracioso y gentil sentido; que, después de habeĩ mostrado la fábrica de su tabernáculo cómo ${ }^{364}$ es muy rica en materiales, muy graciosa en compostura (porque la plata bien labrada sustenta al oro, y las vigas que están en el techo están cubiertas de púrpura, de manera que, de las haces de estos tres preciosos colores -oro, plata y púrpura-, se hace una bella mezcla que se viene a los ojos con graciosa vista), dice luego: "Este tan graciosc pabellón hizo Salomón para sí, en medio del

\footnotetext{
${ }^{359}$ Amplicidod forma no recogida en ninguno de los tres diccionarios con los que estamos trabajando.

${ }^{360}$ Cristiana[s]: concuerda, en singular, con el último de los dos sustantives a los que se refiere.

${ }^{361}$ Defensión: amparo, protección (DRAE, 2). Antiguo

${ }^{362}$ En el manuscrito, salmo 149. En el título del salmo es Himno del pueblo de Dios.

${ }^{363}$ Como: valor temporal-modal.

${ }^{364}$ Haber mostrado la fábrica... cómo: se trata de una doble construcción, pues el infinitivo lleva dos C.D., el sustantivo fábrica y la proposición que comienza en cómo.
} 
cual se entró y esta alií, encendido de amor por una de las hijas de Jerusalén, que era su Esposa", la cual, aunque fuese extranjera de nación, esta riuy avecindada y hecha ciudadana de Jerusalén por haber casado el rey con ella.

Esta es la letra. Y, aunque esto parece haber dicho por el terripio material que Salomón en Jerusalén hizo, de quien ${ }^{365}$ tanta fama hay en las Escrituras Sagradas, o por otra cámara o aposento que en su casa hubiese hecho Salomón; está muy claro entenderse ${ }^{366}$ por la excelente y divina religión que Dios en ei mundo instituía para vivir y estar dentro en ella con su amor, cuyas columnas, que son los maestros y enseñadores que puso en slla para sustentarla, son de piata, quiere decir, todos llenos de doctrina y sabiduría de la divina ley, que esto significa la plata -como ya vimos-. Y estos son columnas fuertes y firmes sobre los cuales se sustenta la religión; no se mueven del lugar donde fueron asentados ni vacilan o se bambolean a una parte ni a otra, porque correría riesgo de destrucción el edificio sin estarse sin aquel enseñamiento del Espíritu Santo [y las] columnas que él asentó. Y así la[s] llama San Pablo, diciendo: Jacob y Cefas y Juan, que parecian ser columnas ${ }^{367}$. Y sobre este conocimiento de la verdadera doctrina y ley está asentada la caridad, por el oro signinícada, la cual cubre el edificio de la religión; porque las columnas serán ${ }^{368}$ ociosas, sin provecho, si no hubiese tejado, pues son hechas a fin de sustentarlo. Y la madera y vigas que hay en este edificio dice que son del Líbano, que es un monte muy celebrado por la frescura suya y la fortaleza de su madera, que cuasi todos los más árboles qie allí hay son cedros y otros olorosos que no se corrompen ni comen de carcoma (y estos son los verdaderos y enteros fieles, que dan buen olor por las bondades que dentro de sí tienen), las cuales vigas están cubiertas de púrpura, que es la sangre de Cristo, que cubre los maderos de este santo edificio y los hace graciosos y resplardecientes a la vista. De manera que [de] la sangre de Cristo, con la cual somos comprados y cubiertos, y de su doctrina y de la fe y caridad nuestra[s] $]^{369}$ consta y está fabricada toda la religión. Y este edificio no bastaron los hombres a fabricarlo, que el mismo Salomón lo fabricó. Él dio la ley y doctrina, la cual entendida y creída ${ }^{370}$, produce caridad en los fieles; él cubrió y amparó las vigas con su sangre; y en este edificio está, en medio de él, abrasado por el aınor de su Esposa, la cual, aunque es una sola en unión de caridad y fe, está congregada de muchas particulares ánimas fieles, y por eso dice: Por las hijas de. Jerusalén.

Salid y ved, hijas de Sión, al rey Salomón coronado de la corona que le puso su madre el día de su desposorio y el día de la alegría de su corazón.

Después que el Esposo dio muestras de sus riquezas y gentileza y del amor que tiene a su Esposa, parece que él saliese muy aciornado y hermoso a la vista de todos, habiendo ya hecho aquella tienda donde estuviese con su Esposa. Y, al salir, la misma Esposa llama a las vecinas

\footnotetext{
${ }^{365}$ Quien: uso de quien referido a cosa, no habitual hoy en dia.

${ }^{366}$ Enteizderse: léase que esta cámara se entiende.

${ }^{367}$ Alusión biblica sin anotación al margen en e! manuscrito. Error del copista; no se trata de Jacob, sino de Santiago. Gálatas (2, 9).

${ }^{368}$ Serán: según el contexto -sobre todo debicio a la siguiente forma yerbal que aparece-, seria esperable aqui una forma de condicional simple en lugar de este futuro imperfecto.

${ }^{369}$ Nuestra[s]: concuercia, en singular, únicamente con el más cercano de los dos sustantivos a los que se refiere

${ }^{370}$ La cual entendida y creida: construcción de participio absoluto, según el uso latino.
} 
mujeres, como ellas suelen ser muy codiciosas de semejantes vistas, para que vean la gentileza y gala de su Esposo, cuán adornado sale de vestiduras y corona real, la cual le puso su madre en la cabeza el día que ${ }^{371}$ él se desposó; y, aquí, "la madre de Salomón", por metáfora, quiere decir "el pueblo de Israel", el cual alzó y crió por rey suyo a Salomón, su hijo que de él había nacido; y parece que él se desposó con su hija de Faraón, que es la pastora que en la certeza de esta letra se pinta, significando otra cosa el meollo de ella. Aquel día salió a la fiesta y bodas Salomón adornado con la corona y otras insignias reales; y, por eso, la Esposa, con el regocijo que siente en verlo, llama a las otras mujeres de Jerusalén que lo vean ${ }^{372}$, y esto es muy comín, que, cuando algunos desposados hay ${ }^{373}$, salen las mujeres a las puertas y unas a otras se llaman y tienen mucha cuenta en mirar las galas que llevan los desposados, y de qué son y cómo las llevan puestas, y de esto son ellas grandes notarias. Pues esta cosa i $\mathrm{i}^{374}$ muestra aquí, y esta voz que las convida a ver puede ser o de la Esposa, que las llama, o de ellas mismas, que unas a otras se llamen; y, de una manera o de otra, no hace diferencia para el entender. Y, diciendo el día de la alegria de su corazón, no se añade seña sino [se] declara más lo de arriba, que dijo el dia de su desposorio. Entendemos en este lugar la madre de Salomón por el pueblo de donde nació; y, aunque se entienda a la letra por su madre, Bersabé, que le hubiese hecho aquella corona o puéstosela en la cabeza, va en ello poco.

Parece que se declare en aquestas palabras el misterio de la glorificación de Cristo, el cual es verdadero Salomón que fue coronado de gloria y reino en el mundo cuando el padre le entregó todas las cosas, como él mismo lo dice. Y esto fue el día de su desposorio, (cuando) ${ }^{375}$ después de resucitado el padre el reino, y aquel día se acabaron de regocijar y celebrar las bodas cuando él abrazó a su Esposa y la tomó para siempre consigo y la hizo una unión consigo mismo, holgándose y regocijándose eternamente con ella sin haber ya en él flaqueza ni pasión de la humanidad, sino sun a alegría, como aquel que de ninguna parte podía admitir flaqueza ni pasión por estar su humanidad muy cercada y fortalecida de la divina descensión ${ }^{376}$ con la deidad suya. Y por eso dice: El día de la alegría de su corazón. Y aquel día salió él de la sinagoga, dejándola ya y yendo a recibir su nueva Esposa, la fiel y cristiana Iglesia; y, así, salió de casa de su madre coronado, porque de la muerte suya ella fue ministra y la que la trató y puso en efecto, por la cual muerte él vino a la resurrección y a ser coronado después y hecho señor y rey, nombrado sobre todos cuantos le nombran, de manera que todas las cosas se humillen oido el sonido de su nombre, como a verdadero señor de todas las criaturas ${ }^{377}$.

\footnotetext{
371 El día que: se trata de un uso muy extendido actualmente, eliminando la preposicióı que debería acompañar al relativo, pues realiza función de complemento circunstancial.

${ }^{372}$ Que lo vean: ya tratamos páginas atrás (nota 283) este tipo de construcciones. En este caso podrian darse, además, otras interpretaciones. Teniendo en cuenta el sentido final de esta proposición, la forma que pociria considerarse una conjunción, en lugar de para que (no es extraf̂a esta polifuncionalidad de que). Podria, sin embargo, tratarse de un uso -semejante al que podemos encontrar en la sintaxis latina- de relativo con subjuntivo indicando valor circunstancial, en este caso, como hemos dicho, final. En cualquier caso, el sentido de la proposición seria el mismo

${ }^{373}$ Cuando... hay: de nuevo un rasgo latinizante en la sintaxis, won esta colocación del verbo haber pestpuesto a su complemento, construcción un tanto extraña al castellano posterior.

${ }^{374}$ Le: parece claramente un error: ie en lugar de se.

375 (Cuando): optamos por la supresión, para evitar el anacoluto.

${ }^{376}$ Descensión: en el manuscrito encontramos la forma desensión.

${ }^{377}$ En el manuscrito, Carta a los Filipenses, 2. Concretaniente se trata de Carta a los Filipenses (2, 9-11)
} 


\section{[CAPÍTULO [V] $^{378}$}

¡Oh, cómo eres hermosa, amiga mía, oh, cómo eres hermosa! Tus ojos son de paloma, fuera de tus copetes. Tus cabellos como mancda de cabras que se levantan en el monte de Galad $^{379}$. Tus dientes como manada de [ovejas] ${ }^{380}$ trasquiladas que vienen de lavarse, las cuales todas paren de dos en dos y ninguna entre ellas hay vacia. Como un hilo de grana son tus iabios; tu hablar gracioso. Como un casco de granada tus mejillas entre tus copetes. Como la torre de David es tu cuello edificado en lo alto; mil escridos en el fin de ella, y todas las

\footnotetext{
${ }^{378}$ [CAPITULO IV]: rexi: amos esta la adición y suprimimos lo que hemos encontrado en el manuscrito (Cap. Cuarto) en un intento de homogeneizar los titulos de los capitulos.

${ }^{379}$ Galad: en el manuscrito aparecen las formas Galaad, Gilgaad, Ghilghad.

${ }^{380}$ [Ovejas]. completamos a partir del Comentario seguin la letra y segúri la explicación que de la idea se da más abajo. Esta palabra no aparece tampoco en el encabezamiento de! parágrafo correspondiente.
} 
aljabas de los valientes. Los dos pechos tuyos como dos cabritos gemelos de una cabra que pace entre las flores. [Hasta que sople el dia y huyan las sombras, irme he al monte de la mirra y al collado del incienso. Toda eres ${ }^{381}$ bella, amiga mía, v en ti no hay tacha. Conmigo del Libano, Esposa mía, conmigo vendrás y mirarás de la cumbre de Amana y de las vertientes de Senir ${ }^{382}$ y Hermón, de las moradas de los leones y de los montes de los pardos. Heriste mi corazón, hermana mia Esposa, heriste mi corazón con uno de tus ojos y con un collar de tu cuello. ¡Cómo son bellos tus amores, hermana mía Esposa, cuánto son mejores que el vino! Y el olor de tus ungüentos, más que todos los olores. Dulzura manan tus labios, Esposa, miel y leche debajo de tu lengua, y el olor de tus vestidos como el olor del Libano. Huerto cercado, hermana mia Esposa, estanque cerrado, fuente sellada. Tus baldados son un jardin de granados con bello fruto. Cánfora con nardo, azafrán y canela y cinamomo ${ }^{383}$, con todos los árboles del incienso, mirra y áloes ${ }^{384}$, con todos los principales olores. Fuente de los huertos, pozo de aguas vivas que manan del Libano. Levántate, cierzo, y ven, austro, y sopla mi huerto y correrán sus olores. Venga mi amado a su huerto y coma del fruto de sus árboles.

\section{[EXPOSICIÓN]}

¡Oh, cómo eres hermosa, amiga mía, oh, cómo eres hermosa! etc.

Porque en muchas palabras y lugares de los que vendrán encontraremos la sentencia de algunas cosas ya pasadas y también las figuras del hablar son muy semejantes, correremos un poquito en los capítulos siguientes, por estar más llano el camino.

En este lugar, el Esposo, incitado de la grande afición que a su Esposa tiene, loa muy particularmente su hermosura, como aque! que la tiene bien conocida y considerada; y, amontonando en estos loores tantas palabras, da gran muestra de la fuerte y continua imaginación que tiene de su amada Esposa, porque estos no son sino trasvertimentos ${ }^{385}$ del corazón, que, no pudiiendo caber la abundancia de los pensamientos, rebosa en las palabras alguna parte de ellos, porque de otra manera reventaría, y esta pasión tiene gran fuerza. En las cosas de regocijo y de amor y de un tal afecto estaba lleno David cuando decía: Rebosa $m i$ corazón dulces palabras, de las cosas que tengo yo que decir del rey ${ }^{386}$. Así, con esta vehemencia este Esposo dentro de sí, rompe el alabar a su Esposa declarando su hermosura parte por parte y dice: ¡Cómo eres hermosa, amiga mía, oh, cómo eres hermosa! Dice esto con

\footnotetext{
${ }^{381}$ Reponemos estas palabras a partir de la cita que encabeza el parágrafo en el que se desarroiıan, algunas páginas más adelante.

${ }^{382}$ Senir: esta paiabra se encuentra en el manuscrito con las siguentes formas: Senir, Seyz, Seir.

${ }^{383}$ Cinamomo: substancia aromática que, según unos, es la mirra, y según otros, la canela (DRAE, 2).

${ }^{384}$ Aloe: Planta perenne de la familia de las liliáceas, con hojas largas y carnosas, que arrancan de la parte baja del tallo, el cual termina en una espiga de flores rojas y a veces blancas. De sus ojas se extrae un jugo resinoso y muy amargo que se emplea en medicina (DRAE).

${ }^{385}$ Trasvertimiento: sustantivo no recogido en el DRAE, aurıque si su verbo correspondiente, trasverter: rebosar el liquido contenia. en un vaso, de modo que se vierta por los bordes.

${ }^{386}$ Alusión biblica sin anotación al margen en el maruscrito. Salmo 45, titulado Poema nupcial al rey mesiánico.
} 
gran regocijo y por eso dobla las palabras, como acá lo vemos, que ${ }^{387}$ una persona que ama dice a la otra "joh, hermano, oh, hermano mío!", "joh, alma mía, oh, alma mía!", y otras semejantes, dando a entender con qué afecto lo dice; que, porque le faltan palabras para declararlo, dice dos o tres veces las que se le ofrecen. Luego pinta por menudo las partes de la bella Esposa, diciendo:

Tus ujos son de paloma fuera de tus copetes etc.

Quiere decir: "Así como la paloma tiene hermosos ojos cercados de unas plumas que les hacen un cerco y les dan muy gentil gracia, así los tuyos están cercados, de una y otra [parte] de tu rcstro, de los cabellos -o copetes de cabellos-". Y estos copetes que aquí dice son dos ramales de cabellos que las mujeres suelen dejar colgarles por la frente, fuera del tocado, cercando el rostro con ellos; y muchas los tienen yostizos, por [no] tener los suyos buena vista, mas la Esposa propios los tiene de su natural, como luego el Esposo dirá. Y arriba se dijo que los ojos de la paioma significaban simplicidad de fe y amor leal; los cabellos de que se cercan estos ojos son los pensamientos, y esto quiere dar a entender que son cabellos de la cabeza del alma, como lo quiso significar el señor cuando dijo: Los cabellos de vuestra cabeza son $\operatorname{contados}^{388}$. Y cuando estos cabellos son hermosos y bien compuestos acompañan bien los ojos de la simple fe cristiana.

\section{Tus cabellos como manada de cabras que se levantan del monie Galad.}

Torna en este capítulo el Esposo a cubrir su persona y vestirse de rústico pastor, por llevar su propósito al cabo, y se sirve en su decir de comparaciones rústicas, apodando los cabellos de su Esposa, de que ya ha hecho mención, a las cabras del monte de Galad, porque los cabellos son parte del ornamento y natural belleza de la mujer, como el Apóstol nos lo enseña. El monte Galad está asentado a la parte occidental del río Jordán y tiene este nombre desde el ccncierto que tuvo ${ }^{389}$ Jacob y Labán, su suegro, como se cuenta en el libro de la creación ${ }^{390}$, y es monte de muchos árboles y frescos, como el Líbano, y de hermosos pastos, como lo dan a entender Amós y Jeremías y Zacarias ${ }^{391}$, y entre las otras plantas que en el se crían hay muchos árboles y matas resmolas ${ }^{392}$. Pues, andando por él las cabras paciendo, como son animales sueltos, se encaraman por los árboles y se meten por las matas, de donde es necesario que los pelos de ellas que son viejos [y están ya poco asidos al cuerpo se salgan y solamente queden

\footnotetext{
${ }^{387}$ Lo vemos, que: de nuevo la construcción frecuente de recoger en un pronombre neutro la proposición completiva que se va a desarrollar después.

${ }^{388}$ En el manuscrito, San Mateo, 10. Concretamente se trata de San Mateo $(10,30)$.

${ }^{389}$ Tuvo: concuerda, en singular, únicamente con el más próximo de sus dos sujetos.

${ }^{390}$ Esta idea se recoge, como sefrala ei manuscrito en anotación marginal, en Génesis, 23. La referencia es errćnea. No se trata del capitulo 23, sino del versículo 23 del capitulo 31, o sea, Génesis $(31,23)$.

${ }^{391}$ En el manuscrito, Amós, 1; Jeremias, 8; Zacarias, 10. En concreto, se trata de Amós (1, 3); Jeremias (8, 22); Zacarias (10, 10), respectivamente.

${ }^{392}$ Resmolas: variante de rezmilas: matas bajeras que raspan; matorral.
} 
los nuevos $]^{393}$ y más arraigados, y estos muy limpios, compuestos y lucios ${ }^{344}$, así por andar ludiendo ${ }^{395}$ y refregándose por las matas y árboles y peñas como porque se untan con la resina que de los árboles se derrite, la cual suele hacer lucir los pelos y cabellos. Y, así, el Esposo dice que los cabellos de su Esposa son tan gentiles, $\tan$ lucios y tan compuestos como suelen ser los de las cabras que andan por las espesuras de Galad, que alli se pelan y peinan y ponen muy hermosas. Y esto quiere decir la voz hebrea; que, donde en nuestra traslación decimos se levantan, el hebreo dice se peinan y pelan. De manera que, por parte de ojos y cabellos, ya está bien loada de hermosa.

Como los cabellos signifiquen los pensamientos e imaginaciones de la Esposa, está claro que esta semejanza de las cabras no sea otra cosa sino estar bien asentados y compuestos los pensamientos, no en alboroto puestos ni levantados, como suelen ser los de los malos y desatinadios sin religión y temor de Dios, que nunca suelen tener reposo en sus pensamientos; antes, siempre andan más inconstantes que las naranjas y el viento lleva a una parte y a otra cada cabello por sí; y, sin ningún arte ni concierto de vida, ahora quieren y no, ya desean otro, ya aman una cosa, ya aborrecen aquello y corren tras lo contrario. Al revés de esto es el justo, que está más sosegado en sus pensamientos y más firme que un monte, porque está muy casado con su bien, que es el conocimiento de Dios, el cual le da tanto reposo que, aunque el mundo se revuelva, no se le alborotan los pensamientos, según la promesa que esta hecha por el intérprete divino: No hará ondear ni alborotar al justo ${ }^{396}$.

Tus dientes como manada de [ovejas] $]^{347}$ trasquiladas que vienen de bañarse; todas paren de dos en dos y ninguna entre ellas hay vacia.

Loa ahora de la hermosura, orden y blancura de sus dientes, porque es gran parte de la belleza exterior, y dice que son tan iguales y tan lisos y tan blancos y están tan juntos como suele parecer a la vista un hato de ovejas trasquiladas que, porque se blanqueen la lana que de nuevo crían, las suelen los pastores -principalmente en aquella tierra- llevar a lavar ciertas veces al día o a la semana. Y (a) las oveja ${ }^{398}$, como hemos visto, vienen muy juntas con su manada, de manera que a quien las mira algo apartado parecen todas una misma cosa blanca, como sábana tendida, que no se ve entre ellas más espacio que [lo que $]^{399}$ hay de los pies de la una a los pies de la otra; porque, por ser delgados los pies y los cuerpos gruesos, se tocan arriba con los lados del cuerpo y abajo llevan los pies una de otra apartadios, y así va aquello

\footnotetext{
${ }^{393}$ Se trata de otro pasaje casi literal al Comentario según la leira. De él tomamos las palabras que añadimos y que creemos necesarias para dotar de sentido a la oración. Puede suponerse, además, fácilmente esta falta como un despiste del copista.

${ }^{394}$ Lucio (3): terso, luicido (DRAE, 1).

${ }^{395}$ Ludir: frotar, estregar, rozar una cosa con otra (DRAE)

${ }^{396}$ Alusión biblica sin anotación ai margen en el manuscrito. Salmo 112, titulado Felicidad del justo.

397 [Ovejas]: ver nota 380

398 (A) las ovejus: suprimimos las preposición, pues este sintagma realiza la función de sujeto de parecen y no necesita, consecuentemerite, de ella. Su aparición puede deberse a la atración por parte de la construcción de la proposición de relativo, en la que el pronombre las (que recoge el sentido de ovejas) realiza la función de C. D.
}

${ }^{399}$ [Lo que]: de nuevo en base al Comentario seguin la letra, creemos necesaria esta adición para dejar ciaro el sentido de la oración. 
negro con la sombra que ellas hacen. Mas, cuando [cuando son llenas y cada] ${ }^{400}$ una ha parido dos, como aquí dice luego, veremos los cordericos entre ellas encajados, de manera que cada madre lleva sus dos hijos a los lados y, así, entre cada dos ovejas dos corderitos vienen a henchir todo aquello vacío que los pies de ellas dejaban. Y, de este modo, no queda entrada a la vista de quien las mira para penetrar entre ellas ni conocer que una esté apartada de otra, sino todo por abajo y por arriba parece un cuerpo blanco y hermoso, como la experiencia lo muestra.

Pues dice el pastor en este lugar que los dientes de su Esposa son ni más ni menos, porque ellos son blancos en el color como las ovejas recién bañadas y son tan parejos y juntos unos con otros como las inismas ovejas cuando vienen en su manada. Y, porque muchas personas tienen los dientes por la parte de arriba juntos, mas, por sus nacimientos, donde juntan las encías, los tienen apartados, demás ${ }^{401}$ [de] que pueden meter por entre diente y diente un buen alfiler, como lo vemos en muchas bocas; por eso ${ }^{402}$ dice el Esposo que los dientes de su Esposa están tan juntos por abajo como por arriba, tan iguales y parejos como las ovejas que vienen cada cual con dos cordericos, que ninguna hay vacía entre ellas. Y los pudiera comparar a un sartal de perlas o a otra tal cosa preciosa y gentil, como hacen otros enamorados, mas con esta semejanza de las ovejas guardó mejor el decoro y conveniencia de pastor y declaró mucho más la hermosura y igualdad de ellos que con ninguna otra semejanza de las otras se pudiera declarar.

Y esta es una de sus grandezas de la Escritura Divina, que, no solamente en las cosas que dice $\operatorname{mas}^{403}$ aun en la manera de decirlas, vence a todas las otras escrituras. Una de las cosas que los dientes significan en las Santas Letras es [que] la reprensión sea un morder con la boca a otro; y es tomado este símbolo de los perros y, por tanto, los reprendedores son llamados perros en esta lengua. Pues tiene la Esposa sus dientes de reprensión, mas estos no son agudos ni dañadores como los de los perros sino semejantes a unas ovejas, porque los castigos y reprensiones con que la Esposa muerde a los que van errados son simples, claras y puras con palabras evangélicas ${ }^{404}$. No arguye ni acusa con furia ni odio sino con amistad y mansedumbre, porque no es su intento $(\mathrm{de})^{405}$ morderlos, roerlos ni despedazarlos, $\mathrm{a}^{406}$ forzarlos $\mathrm{o}$ inducirlos a desesperación, sino (de $)^{407}$ asirlos livianamente, sin hacerlos mal, y, asidos, juntarlos consigo a

\footnotetext{
${ }^{400}$ Nueva adicién segin nuestro otro Comentario. Sintácticamente no seria necesaria, pues la oración resulta congruente, de modo que podria pensarse, no en un fallo de copista, sino en una modificación del texto. Sin embargo, nos paræce oportuna, dado que, un poco más abajo, afirma que cada madre lleva sus dos hijos a los lados.

${ }^{401}$ Deriás: léase hasta tal punto.

${ }^{402}$ Por eso: retoma la construcción comenzada tres lineas más arriba $(Y$, porque...)

${ }^{403}$ Mas: equivalente a sino.

${ }^{404}$ Porque... evangélicas: encontramos una clara incongruencia en esta proposición. Las soluciones posibles son dos. Por un lado, puede tratarse de que los adjetivos (simples, claras y puras) vayan referidos a castigos y reprensiones; en este caso, se tratariá de un fallo de concorciancia. La otra posibilidad es que la preposición con que aparece después de los adjetivos debiera ir colocada antes uque elios, de modo que estos fueran referidos a palabras evangélicas.

${ }^{405}(\mathrm{De})$ : suprimimos la preposición pues, según los usos modernos, estos infinitivos realizan la función de sujeto y, por tanto, no la necesitan.

406 A: equivalente a para. El mismo caso se da en la linea siguente.

${ }^{407}(\mathrm{De})$ : caso análogo al anterior.
} 
hacerlos un mismo cuerpo consigo. $\mathrm{Y}$, así, es igual y pareja esta reprensión, porque no reprende a unas personas más que a otras porque $\operatorname{los}^{408}$ quiera mal y aborrezca; antes, a todos quiere bien y tiene un mismo celo para con todos. De esta manera entendió Jacob los dientes cuando de Cristo profetizó: Más 'hermosos son sus ojos que vino y sus dientes más albos ${ }^{409}$ que la leche $\boldsymbol{~}^{410}$.

Como un hilo de grana tus labios; tu hablar gracioso. Como un casco de granada tus mejillas entre tus copetes.

Prosigue en pintar la belleza de su Esposa dándole los colores más propios que hay para denotar ser sumamente bella. Y, tras la mención de los dientes se ofrece la de los labios, los cuales para ser hermosos en una mujer han de ser delicados y de un color bermejo; tales muest:a el Esposo ser los de su Esposa en decir que son como hilos de grana o púrpura. Y porque, como hemos dicho, la hermosura se conoce principalmente en las acciones y muestras del ánima, con las cuales se dan a entender los afectos y movimientos interiores, como el reír, el andar y mucho más el hablar, que, siendo honesto, mesurado y gracioso, afina y sube en grandes quilates la hermosura y belleza; por eso ${ }^{411}$, en hablando de los labios y dientes, dijo luego del hablar, como si dijera: "Tienes tú, Esposa mía, los instrumentos del paladar tan lindos y delicados, de tan perfecta compostura, que era necesario que tu hablar saliese muy gracioso y delicado, porque en un buen artífice con buenos insirumentos, cual es tu ánima con los suyos, siempre saca gentiles y agraciadas obras".

Se entiende este lugar del hablar gracioso y honesto de la espiritual Esposa, el cual procede siempre de los rubicundos labios de caridad de que ella está muy llena. Y, así, en muchos lugares de la Sagrada Escritura, por los labios hermosos o graciosos se entiende el hablar.

Pues de esto scn loadas las mejillas de la Esposa hermosa. Porque la blancura del rostro, si es fuerte y continuada por todo él, antes muestra figura de muerto o estatua de muerto o estatua de piedra sin ánima; por eso suelen tener los verdaderamente bellos rostros las mejillas rojas y este color que en ellas hay está muy asentado y dice muy bien. Y suele $\operatorname{ser}^{412}$ su adjunto más gracioso en aquellos dos montecillos que se levantan sobre el hueso de las mejillas, los cuales, siendo un poco ampollados y levantados de la otra igualdad del rostro, tiene[n] gran semejanza con dos cascos de granada mondados de su cáscara, que son arrollados un poco y muy hermosos en el rojo del color y lucientes de un resplandor gracioso. Y, así, la semejanza, aunque rústica, es muy a propósito. $Y$ estas mejillas son muy hermosas acompañadas del hermoso cabello.

Son las mejillas, de quien tanto el Esposo se contenta, el vivir de su Esposa, porque, así como las mejillas son descubiertas a todos, que no se esconden, así la vida de su Esposa es muy patente y descubierta, de manera que todos ven y entienden su hermosura. Y esta manera

\footnotetext{
${ }^{408}$ Los: fallo en la concordancia, pues el sustantivo al que se refiere es personas.

${ }^{409}$ Albo: blanco.

${ }^{410}$ Alusión biblica sin anotación al margen en el manuscrito. Génesis $(49,12)$.

${ }^{411}$ Por eso: recoge la construcción comenzada cinco líneas más arriba $(Y$ porạue...

${ }^{412}$ Ser: entiénciase estar.
} 
de vivir de la Esposa está vestida toda de caridad inflamada en el amor divino y del prójimo, y parece muy bien al Esposo cuando está cercada de los hermosos copetes de los buenos y santos pensamientos, de manera que lo que muestra fiera, en la manera de vivir, conforma ${ }^{413}$ con ei ornamento de los santos pensamientos.

Como la torre de David es tu cabello edificada ${ }^{4 / 4}$ en las alturas; mil escudos cuelgan de ella, y todas las aljabas de los valientes. Los dos pechos tuyos son como de dos gemelos de una cabra que pace entre las flores.

La hermosura corporal tiene su adjunto en dos lugares: el principal es la graciosa proporción de las facciones del rostro, y sus vivos colores; el otro es la disposición del cuerpo, que sea alto, en buena proporción y no muy grueso más de cuanto convenga a la correspondencia de la altura. De la primera parte ha dicho harto el Esposo como muy contento de la beldad del rostro de su Esposa. Aquí, a son ${ }^{415}$, dice de la otra segunda parte. Y, para decir que ella es alta y muy agraciada, conforme a si altura la semeja a la torre que hizo David en el monte Sión; y esta estaba asentada sobre el monte, en la cumbre y medio de él, de manera que hacia [una] parte y a otra iban las vertientes del monte debajo de ella, y se veía desde lejos. Y dice que en ella estaban muchos escudos y aljabas que adornaban. [Puede ser] o que estos fuesen verdaderos escudos y armas puestas alli para servicio y defensa de la torre, que estaban colgados de las almenas por enderredor de ella; o que fuesen tallados de piedra o de otra cualquier materia para adornamento ${ }^{416}$ de la torre, como solían hacer los antiguos. De una manera y de otra puede estar el mismo sentido: que en estas palabras da a entender cómo su Esposa sea gentil de disposición y estatura, diciendo: "Es tu cuello, Esposa, con el atavio de sus collares tan hermoso, derecho y levantado como la torre de David con sus escudos y aljabas, que mucho adornan y hermosean. Y, asi, está asentado tu cuello sobre un gentil y bien dispuesto cuerpo. Y con tanta gracia se inclinan los hombros de una parte y de otra como la torre que he dicho está asentada sobre el monte. Y, después de este cuello, se levantan dos pechos tuyos tan graciosos, tiernos y redonditos, bien llenos, no flojos, que parecen dos cabritos iguales de cuerpo y días que una cabra haya parido mellizos; y estos tus pechos, con su blancura bellísima, se mueven [tan] suavemente que no parecen sino los mismos cabritos que andan paciendo y retozando entre lirios y violetas blancas".

Ya arriba dijimos que el cuello daba a entender la voluntad de la divina Esposa, la cual loa y precia mucho su Esposo cuando ella está levantada a lo alto, derecha y fuerte, solamente queriendo y amando las cosas altas y divinas, $\mathrm{y}$ en aquellas afirmándose, muy adornada de los joyeles de la palabra de Dios, el vivo fuego, como lo dice Salomón ${ }^{417}$. Y, para esta belleza ser acabada, es necesaria la lindeza de los pechos, que son los dos Duanos Testamentos, hermosos y blancos pechos de la santa Esposa, con cuya divina leche se mantienen sus hijos. Y, así, no solamente ella es hermosa por sí y por la buena intención de su voluntad, adornada de las

\footnotetext{
${ }^{413}$ Conforma: más habitual resulta actualmente utilizar este verbo en forma pronominal. El sentido que encontramos en nuestro texto suele expresarse mediante la expresión analitica ser conforme.

${ }^{414}$ Torre... edificada: hipérbaton.

${ }^{415}$ A son: modo adverbial, que vale tanto como tocándose actualmente tcl, ò tal instrumento (Dic. Aut.)

${ }^{416}$ Adornamentc: adornamiento.

${ }^{417}$ En el manuscrito, Proverbios, 3. Concretamente se trata de Proverbios $(3,14-20)$.
} 
divinas palabras, sino también hermosa por los pechos con los cuales celestialmente mantiene [a] sus tierros hijos.

Hasta que sople el dia y huyan las sombras, irme he al monte de ia mirra y al collado del incieisso. Toda eres hermosa, amiga mia, y en ti no hay tacha.

Después de haber con grande y amoroso regalo contado la hermosura y loores de la Esposa, dando un pregón por sí a cada parte de su belleza, dice que se quiere ir a los montes de la mirra y a los collados del incienso mientras que viene la luz del día. Y aquesto podemos conjeturar: que estos loores que cantando publicaba el buen pastor enamorado los celebraba de noche, a fuer $[\mathrm{z}] \mathrm{a}^{418}$ de los que suelen dar alboradas a las que bien quieren. E, yendo en el cantar, prosigue diciendo: "Yo estoy muy contento de tu gran belleza y quiero por tu servicio, antes que sea de día, irme a los montes donde se coge la mirra $(y)^{419}$ para apañar y coger allí de aquellos preciosos olores de que hay abundancia y traerlos con que se adorne ${ }^{420}$ tu beldad, lo cual $^{421}$ yo he cantado engrandeciéndola mucho. $Y$ así me rectifico ${ }^{422}$, concluyendo que eres hermosísima toda, que en ti no hay tacha, ruga ${ }^{423}$ ni mancilla ni parte ninguna donde la envidia tenga lugar de entrar contradiciendo ni tachando". Y esto es muy común y de buen artificio, recopilar en pocas palabras las cosas que por otras muchas se hayan publicado y propuesto, porque se afirma así lo que está dicho. Y aun se comprende más diciendo: Toda eres hermosa.

Son los montes de mirra y los collados del incienso los príncipes y cabeza de la religión, cuya doctrina y buenas cbras dan suave olor de sí, de tal manera que la espiritual Esposa se contenta mucho y recibe gran recreación con tales olores; y de esto provee el Esposo a su Esposa como suelen hacer los enamorados a sus amadas proveyéndolas de flores, rosas, clavellinas para su ornaniento, como es uso hoy día en las tierras que están hacia levante y $\mathrm{en}^{424}$ su muestra entre los labradores y rústicos. A esto dice el Esposo que quiere ir hasta que las [sombras] iiuyan y venga el dia porque todo el tiempo (que ${ }^{425}$ la Esposa está aún esperando el día de su presencia de su sagrado Esposo, cuarido él haya de venir [a] sacarla de la imperfección y ponerla en el día de la admirable lumbre del día del mismo Esposo. En todo este tiempo él no deja de enviarle presentes de mirra, incienso y de todos los demás olores que los montes de saludable doctrina suelen fructificar, para que ella se alegre y consuele con ellos y esté más adomada.

\footnotetext{
${ }^{418}$ A fuer [z]a: agregamos la $z$ en base al pasaje paralelo del Comentario segin la letra, intentando dotar de sentido la expresión.

${ }^{419}(Y)$ : suprimimos la conjunción, dado que la proposición que la sigue no está coordinada con la anterior sino que es subordinada de ella.

${ }^{420}$ Con que se adorne: claro caso de relativo + subjuntivo con valor cirtunstancial -según el uso latino-, en este caso indicando finalidad.

${ }^{421}$ Lo cual: fallc de concordancia, pues su antecedente es beldad.

${ }^{422}$ Rectificar: reducir una casa a la exactitud que debe tener (DRAE, 1). Acepción actualmente en menor uso que: modificar la propia opinión que se ha expuesto antes (DRAE, 4).

${ }^{423}$ Rriga: arruga.

${ }^{424}$ En: probablemente se trate de un error: en por es.

${ }^{425}$ (Que): suprimimos el relativo para evitar el anacoluto.
} 
Este tiempo de la noche en que la Iglesia estaba fue antes que viniese el resplandor del padre y luz verdadera que alumbra a todo hombre que viene a este mundo, en el cual tiempo no dejaba[n] de venir presentes y enseñadores de la Doctrina Sagrada. Y es también este tiempo ahora $\mathrm{a}^{426}$ cualquier particular ánima Esposa del divino [Esposo para] amarlo, cuando, cayento y obrando siempre y agradando a Dios y esperando sus promesas, aún no está confirmada, mas [se] espera la confirmación de la justicia, santidad y verdad. En el entretanto nunca faltan visitas, los presentes y regalos que el Esposo le envía por mano de los buenos maestros, para que se aliente mediante aquellos buenos olores y tenga más fija su esperanza. Y, porque todos estos ejercicios con que la enamorada Esposa se arrea, componiéndose en su ánimo lo más que le es posible, [son para] agradar al divino Esposo, por eso concluyó diciendo: Toda eres bella, amiga mia, y en ti no hay tacha.

Conmigo del Libano, Esposa, conmigo del Líbano ven y mira de la cumbre de Amana y de las vertientes de Senir y Hermón, y de las moradas de los leones y de los montes de los pardos.

No se tarda mucho el Esposo en venir a su Esposa del lugar que estaba -un poco apartado, como vimos- $y$, en viniendo, la llama que se vaya con él, que anden ambos juntos, y le dice: "¡Oh, Esposa mía, que te he yo tanto deseado por lo mucho que te amo! Ven conmigs; anda acá, ven conmigo, no andes sin mí, que no quiero andar sin ti. Deja esos nontes cerca de donde estas, esos montes del Líbano, Amana, Senir, Hermón -que eran montes en tierra de Jerusalén, donde la Esposa estaba-. Mírame desde esos montes para que me veas y halles". Y, porque dijo "montes", repite el decir, declarándolos y diciendo: "Desde esos montes bravos donde se suelen criar leones y pardos y otras bestias fieras". Y esto le dice porque con mayor presteza se vaya la Esposa a él, dejando y huyendo el peligre de aquellos inontes y lugares salvajes y ásperos.

Entendemos por este llamar del Esposo (por) ${ }^{427}$ el tiempo de luz, vida, gracia y justicia, el tiempo aceptable y los días de salud, cuando el soberano Esposo llama a su Esposa, la cual estaba entonces en tierra de Israel, que aquí se significa por los montes cuyos nombres señala. Y, porque del pueblo de Israel y gentil era hija la Esposa sagrada, la amonesta, la ruega ${ }^{428}$ que se parta luego para él, no solamente de los montes del Líbano, Amana, Senir y Hermón, mas ${ }^{429}$ de los otros montes de los leones, que son los lugares donde el demonio, enemigo nuestro, leóin, bravamente anda ejercitando su crueldad, procurando presa que despedaza y le traga ${ }^{430}$. Y le manda también que le mire desde las cuevas de los pardos, porque ${ }^{431}$ huya de los tales lugares y se venga a él. Los pardales o los pardos, por la variedad de pintas y manchas que tienen, dan a entender la diversidad de las letras y doctrinas humanas, que solamente tenían por

\footnotetext{
${ }^{426}$ A : equivalente a para.

${ }^{427}$ (Por): suprimimos la preposición, que rompe la cc. istrucción y hace perder el sentido.

${ }^{428} \mathrm{La}$ ruega: hasta ahora, en la aparición de los pronombres $l e$, la y lo, habiamos encontrado, en general, un uso etimológico, además cie ciertos casos de loísmo. A partir de aqui, esto no será tan constante, pues alternan pasajes que sigueñ en esa linea con otros en los que aparecen casos de iaismo y leismo (pero no de loismo).

${ }^{429}$ Más: equivalente a sino.

${ }^{430}$ Presa que despeduza y le traga. presa a la que despedaza y traga. Ver lo comentado en nota 246. Aqui, además, ericontramos un fallo de concordancia, pues el antecedente del pronombre es femenino (presa).

${ }^{431}$ Porque: valor final.
} 
oficio (de) ${ }^{432}$ gastar y despedazar los mismos de los hombres trayéndolas ${ }^{433}$ muy dudosos y alborotados, y en ninguna resolución en el camino de la verdad. De aquí, pues, de estas asperezas, llamó el divino Esposo, con grande amor y ardiente ${ }^{434}$, de esto a su Esposa para ponerla en seguridad y traerla siempre consigo, muy guardada de todos estos barrancos y peligros.

Heriste mi corazón, hermana mía Esposa, heriste mi corazón con uno de tus ojos y con un collar de tu cuellc.

No se puede disimular el amor por aquella persona en quien reina ${ }^{435}$; iuego pone su escudo en el rostro del enamorado, luego lo hace a él mismo pregonero de su pasión. Todas las otras pasiones y afectos del corazón pueden hacer menos ruido y estruendo dentro en él, de manera que los de fuera no sientan quién esta allá; mas este vivo fuego no puede estar que no humee, dé estallidos, brame y deje llama. Y esto ha sido cavisa michas veces de graves afanes, fatigadas ${ }^{436}$ y descontentos a los amadores, porque muchas veces une acierta [a] amar un corazón rústico y avillanado o altivo, el cual parece que le ama anies que sepa cuánto es amado; mas, después que el otro le descubre la gran revuelta de sus pensamientos, que por su causa le hacen guerras, viendo que $1 \mathrm{a}^{437}$ tiene sujeto, se ensoberbece y no le muestra el amor que primero, cosa indigna de nobles corazones. Y tanto más ha de haber compasión del que en tai modo padece por haber descubierto sus entrañas cuanto menos fue en su mano dejarlas de descubrir.

En este lugar, venido y[a] el Esposo a la conversación de su Esposa, le comienza tiernamente a mostrar las varias cosas de su corazón que su mayor en él ha imprimido, diciendo: "¡Oh hermana mía! ¡Oh Esposa mía! Has herido mi corazón, lo has herido y despedazado con solo un ojo tuyo y con solo ur collar de tu cuello"; quiere decir: "Con sola una vista, de una vez que me miraste y de una vez que yo te vi", dando a entender cuán súbito se apoderó en el amor. "Que apenas una vez lo hubiste para mí tan gracioso mirar cuando sentí en mi corazón la herida de tu amor". Y, repitiendo dos veces la razón "heriste, heriste mi corazón", muestra la vehemencia y fortaleza de su amor. $Y$ argumenta en sus palabras, como si dijese: "Si sola una vista tuya y un collar de los que tú sueles ponerte cuando te engalanas basta para rendirme herido en tu amor, ¿cuánto más serán para meter a prisa en tu poder y amor todas tus vistas, tus hablas, tus risas y tu beldad todas juntas?"

Ya arriba dijimos que los ojos eran imagen del buen juicio del ánimo, conformado a la ley divina y la buena fe los collares -también las buenas y santas obras de los creyentes-. Los

\footnotetext{
${ }^{432}(D e)$ : suprimimos la preposición por tratarse de un verbe transitivo, no necesitado de ella según los usos actuales

${ }^{433}$ Trayéndolas fallo de concordancia. El pronombre cuclitico deberia ir en género masculino, pues refiere a kombres. Prohablemente se deba a la atracción del sujeto, que es femenino.

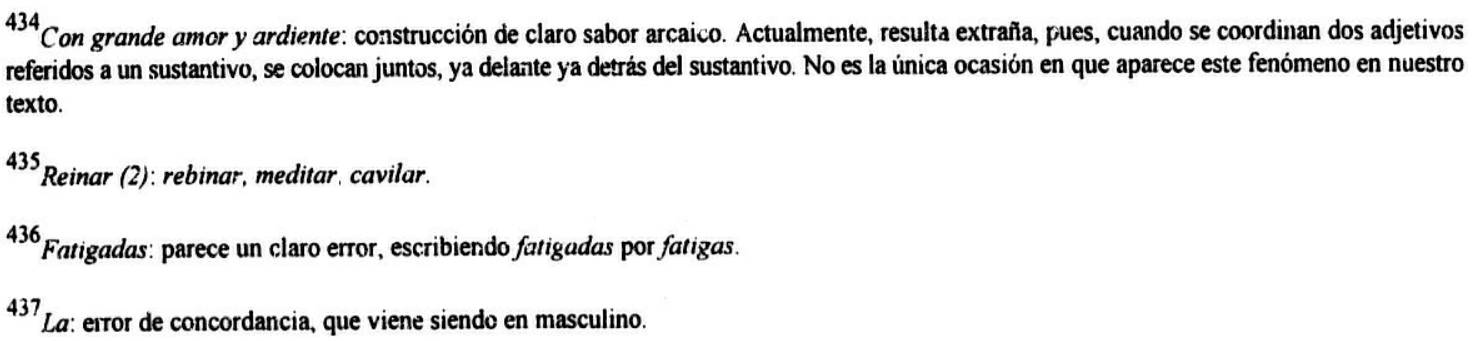


cuales ojos y collares hacen enamorar al divino Esposo, porque él lo declara y dice a entender ${ }^{438}$ cuánto sean agradables a él estas dos partes cuando dijo: Si me amáredes y guardáredes ${ }^{439}$ mis mandamientos estaréis muy de asunto en mi amor ${ }^{440}$. Asi que este buen enamorado bien muestra el amor que tiene a su Esposa sin que ella se lo pregunte.

En la letra dice hermana Esposa, llevando todavía la semejanza de las palomas, que suelen ser entre ellas las dos hermanas de un nido, …hos y juntos casados $y$ apareados ${ }^{441} ;$ y, para mostrar el grande amor que le tiene, la llar d hermana y Esposa.

¡Cómo son graciosos tus amores, hermana mía Esposc, cuánto vencen en bondad al vino! Y el olor de tus ungüentos, más que todos los olores. Dulzura manan tus labios, Esposa, miel y leche debajo de tu lengua, y el olor de tus rosas como el olor del Libano.

Añade todavía loores a la hermosura de su Esposa como aquel que tanto la ama que no puede callar su amor ni se harta de alabarla. $\mathrm{Y}$ asi prosigue: " $\mathrm{OOl}$, hermana mía querida y dulcísima Esposa! Graciosos y bellos son tus amores; más suavidad y alegría rne pone amarte que la que suele poner el vino a los que lo beben con gran gusto. Tus aceites, que son algalias y los demás olores que traes, [de] donde sale tanta fragancia, vence[n] a todos los olores del mundo, que los que otras traen no huelen tan bien como los tuyas ${ }^{442}$. Tus palabras son tan dulces que no parece sino que tu lengua anda bañada en miel y leche, y tus labios derraman tanta dulzura como el panal de la miel. Tus vestiduras te están tan bien, te adornan y huelen tanto que pareces con ellas el bello monte Líbano, donde hay tanta frescura, y así en la vista de las verdes y floridas plantas como en los suaves olores que alli el aire mezcla. Demanda ${ }^{443}$ que en ti están muy contentos todos mis sentidos: vista, gusto y olor". Esto parece que quiere decir, a la letra, el enamorado Esposo.

El espiritual sentido está claro por haberio dicho otra vez arriba en la misma sentencia, salvo las vestiduras cuyo olor le da tanto contento. Estos son los santcs y verdaderamente amigos de Dios, justificados por su gracia, hechos miembros de Cristo y también de la Iglesia, su Esposa; los cuales son ornamentos y vestiduras de slla, como $^{444}$ promete Dios (de) ${ }^{445}$ adornarla con tales ropas y dones, diciendo: 'Dice el Señor que todos estos como atavio te han de vestir y cubrirtelos has como desposada"446. Y el olor de estas vestiduras entendía el

\footnotetext{
${ }^{438}$ Dice a entender: parece claro el error, escribiendo dice por da.

${ }^{439}$ Guardáredes: ver nota 77.

${ }^{440}$ Alusión biblica sin anotación al margen en el manuscrito. San Juan $(14,15-16)$.

${ }^{441}$ Ambos... apareados: ruptura en la concordancia, pasando al masculino desde el femino de palomas.

${ }^{442}$ Los tuyas: evidente fallo de concordancia.

${ }^{443}$ Demandar: hacer cargo de una cosa (DRAE, 4;

${ }^{444}$ Como: léase seguin.

445 (De): suprimimos la preposición por trată se de un varbo transitivo, nc necesitado de alla según los usos actuales.

${ }^{446}$ Alusión biblica sin anotación al margen en el manuscrito. Isaias (6i, 10-1!).
} 
Patriarca $1{ }^{447}$ que de Cristo decía: 5ll olor de mi hijo como el olor de un fresco campo y $1 l e n 0^{448}$, como más adelante se declara en la letra. Y significan las vestiduras de que está adomada la Esposa estas ropas cuya hermosura y buen olor dan mucho contento. Y se celebran estas vestiduras en aquel epitalamio -o canción de bodas- que el profeta hizo regocijando y festejando en espiritu estas bodas mismas que aquí tratamos, diciéndole al desposado: $A$ tu lado está la desposada reina, vestida de brocada y oro, y cubierta de diversas, bellas y ricas ioyas $^{449}$.

Huerto cerrado, hermana mía Esposa, estanque cubierto, fuente sellada. Tus baldios son un jardin de granados [con] ${ }^{450}$ bello fruto. Cánfora con nardo, azafrán y canela, cinamomo, con todos los árboles del incienso, mirra y áloes, con todos los principales olores. Fuente de los huertos y pozo de aguas vivas que manan del Libano. Levántate, cierzo, y ven, austro, sopla mi huerta y mover se han sus olores.

El rústico y gracioso Esposo no deja de mostrar la elocuencia que en las escuelas de amor ha deprendido ${ }^{451}$, y así, con una semejanza y otra, alaba la belleza y gracia de su amada Esposa. Habiendo pues arriba tratado en particular de su hermosura y después concluyendo que toda ella era bellísima, sin ruga ni tacha, ahora, por una maravillosa semejanza, confirma lo dicho de esta manera: "Tan acabada eres, hermana y Esposa mia, y tan perfecta en toda belleza y gracia que pareces un huerto de muy lindas plantas, así de vista y sombra como de olor y fertilidad, donde hay muchas flores, muchas hierbas olorosas y sanas; y este huerto está cercado, de manera que ninguna bestia pueda hacerle daño, y en él está una fuente, no de agua encharcada sino de agua viva que corre, la cual esté cercada al derreỏor, que ninguna cosa la puede turbar ni revolver, $\operatorname{mas}^{452}$ siernpre conserve su clareza ${ }^{453}$, siempre mane agua viva".

$\mathrm{Y}$, donde dice el texto vacios, los hebreos dicen que significan lugares sequios -en las otras donde no alcanza la agua para regarlos ${ }^{454}$. $Y$ dice el Esposo que, aun lo que suele estar seco y sin provecho en los otros huertos, en este -a quien apoda a su Esposa- es fructifero y !leno de hermosos granados que producen gentil fruto, dando a entender que [en] toda parte es herrnosa y perfecta su hermosura, sin haber qué tachar en ella, como ya ha dicho. Y, para declarar qué plantas son las de aquel huerto, encaja un gran número de olores y preciados árboles, sin otros fructíferos que se entiende aún en él, de suerte que viene a ser un deleitosísimo jardín el que pinta, y tal dice que es su Esposa, tal su belleza y gracia. $Y$, siendo esta semejanza tan graciosa y apropiada que tanto comprende, la repite dos veces en la letra para más aumentar la

\footnotetext{
${ }^{447}$ La: probablemente, $l o$.

${ }^{448}$ Alusión biblica sin anotación al margen en sl mar:uscrite Salmo 45 , titulado Poema mupcial al rey mesiánico.

449 Alusión biblica sin anotación al margen en el manuscrito. Salmo 45, titulado Poema nupcial al rey mesiánico.

${ }^{450}$ [Con] : completamios segun el texio aparecido al principio del capítulo.

${ }^{451}$ Deprender: aprender.

${ }^{452}$ Más: equivalente a sino.

${ }^{453}$ Clareza: claridad.

454 Las otras... regarlos incongruencia en la concordancia. Podria tratarse de que faltara una palabra como partes (en las otras partes). En ese caso, deberia haber aparecido la fonna regarias. Siri embargo, si la concordancia se sigue a partir de lugares, serian las otras las que, al ir en femenino, quedarian fuera de la concordancia.
} 
significación de lo que dice, dibujando la hermosa, fresca y clara fuente con que su huerto se riega. Dice que sus aguas manan del Libano, para dar a entender cuán generosa y de cuánta suavidad sea la agua, pues nace de un monte y el monte es de los más nombrados que hay en la Sagrada Escritura, porque produce hermosas y muy estimadas plantas de olor, vista y fruto, y es natural que de los veneros ${ }^{45}$ de tan buena tierra tome muy buenas calidades el agua. Y, así por esto como por la guarda que dice haber en esta fuente, será muy preciada.

Así como hemos traído esta semejanza del huerto y está muy bien traída para la Esposa de la letra, así lo está para declarar la cumplida beldad de la espiritual, porque no es otra cosa esta sagrada Esposa sino un huerto todo plantado de celestiales maravillas, de grandes y divinas virtudes y de maravillosas excelencias que este pueblo fiel tiene. Y [es el huerto] esta Iglesia, Esposa de Dios, con todos sus miembros, de los cuales sale un suavísimo olor que da noticia de su lindeza a todo el mundo; y es tan fértil, tan lleno de tantos frutos y frescuras que no hay esterilidad en él, porque son muy escogidas sus plantas, y el suelo de buena tierra; y el labrador es Dios, que él lo planta y a él se debe la gloria de todo; y este huerto está siempre cercado y guardado del divino socorro, porque así lo muestra la Escritura Sagrada, diciendo: Guarda el señor a los que lo temen ${ }^{456}$. Y se riega con las claras aguas de la fuente de la Sagrada Doctrina, que desciende del alto monte del cielo, y esto es causa [de] que tanto crezcan las bellas plantas de este huerto. Esta fuente está cerrada y guardada, sin ser revuelta ni turbada con la vana doctrina humana o con el vino de la hipocresía. De manera que, con esta hermosura, con esta cerca y con este riego, viene a ser este jardín tan deleitoso que por semejanza de él muestra Dios la hermosura de su Esposa.

En habiendo hecho pintura y mención de este huerto el Esposo, sin dejar la metáfora que tomó, comienza luego a echar peticiones y ruegos y [a] desear la prosperidad y felicidad de su Esposa, diciendo: "Levántate, cierzo, y ven, austro, y sopla en este huerto mio con un airecico tempiado, no áspero ni frío como e! del cierzo sino suave y tibio, para que, con el calor, despierte el olor de estas graciosas plantas y sus frutos, $y$, con los movimientos, lleves aquella suavidad y la derrames por un ${ }^{47}$ torno del huerto, que todos gocen de este deleite y amen y bendigan un tan gracioso jardín". Y esto está claro y es muy conforme bendición a la naturaleza de huerto, según la regla que ya arriba referimos, que, cuando bendecimos 0 , aborreciendo, detestamos [a] alguna persona o cosa, hablamos conforme a su oficio y naturaleza, como lo hizo el elegantísimo David en aquella lamentación que hizo sobre la muerte de Saúl, diciendo: ¡Oh montes de Gélboe ${ }^{458}$, estériles seáis sin ningún fruto ni planias, privados del beneficio del cielo! iQue ni rocio ni agua descienda [n] sobre vosotros ${ }^{459} \mathrm{Y}$ otros muchos lugares hay semejantes a estos.

El viento cierzo que viene de la parte del monte es tenido por dañoso en la Sagrada Escritura, y principalmente es desgraciado para los huertos y jardines que tienen frescas y

\footnotetext{
${ }^{455}$ Venero: manantial de agua (DRAE, 1).

${ }^{456}$ Alusión biblica sin anotación al margen en el manuscrito. Salmo 31, titulado Súplica y acción de gracias de un afligido.

${ }^{457}$ Un: parece un error: un en lugar de en.

${ }^{458}$ Gélboe: en el manuscrito, Gelbos.

${ }^{459}$ Alusión biblica sin anotación al margen en el manuscrito. II Samuel $(1,21)$.
} 
tiernas plantas, cual lo pinta aquel Esposo. Y, por eso, en decirle que se levante, le manda que se venga y no empezca ${ }^{460}$ a su huerto, que es su Esposa hermosísima, y llama al austro, que nosotros decimos "abugo", el cual sopla de mediodía y, así, es menos grave. Y esta bendición vino a muy buen tiempo y con gentil decencia y gracia, como si dijera el Fsposo: "Es mi Esposa un fresco huerto. Dios me lo guarde de malos vientos, y el amparo del cielo me lo favorezca". Como acá uno, apodando a su esposa o enamorada a rosa o clavellina, dice que plegue $^{461}$ a Dios que nadie se la coja o maltrate.

El espíritu de esta bendición es que el Esposo desea que de esta su Esposa huya y se arredre toda infelicidad e infidelidad y cualquiera fiero y áspero vicio que seca y quema las plantas del huerto, cuya imagen ha plantado, y venga[n] la gracia, calor y favor del Espíritu Santo, que de tal manera penetre los corazones de las plantas que anime sus virtudes y les de vida tal que se manifieste por labor de la fama a todas las gentes.

Venga el mi amado a su huerto y coma del fruto de sus manzcnas.

Según que ya hemos dicho, el olor y celebración que el Esposo, con tanto regocijo, ha hecho de ia hermosura de su Esposa debajo de estas semejanzas eran cuando ya él estaba junto a ella -o muy cerca-. Y ella, oyendo lo diicho -su respuesta de la semejanza del huerto-, [está] como muy contenta de verse tan amada y loada de su Esposo, y dice: "Pues que vos me hicistes semejante a un bello jardín, oh amado Esposo, y dijistes ${ }^{462}$ que yo era vuestro huerto; así lo confieso ya y digo que soy vuestro y que todos mis frutos y todo lo que en mí se puede gozar es para vos. Venid, Esposo mío, coged y comeréis de los buenos frutos que en vuestro huerto tanto os han contentado, que yo vuestra soy, y no mía ni de otro fuera de vos; todo el bien que en mí ha crecido me nació de vos y se aumentó con vuestro favor, por haberme vos amado y yo a vos. Coged, pues, de vuestro fruto y comed".

Esto está claro [en] el espíritu, que la Esposa desea que su Esposo venga a ella y goce y se agrade de los frutos suaves de las buenas obras suyas, porque ella no las ha hecho por agradar a otro que a su Esposo y conoce ${ }^{463}$ que su Esposo le haya favorecido en ellas en su crecimiento y madureza.

\footnotetext{
${ }^{460}$ Empecer: dañar, ofender, causar perjuicio (DRAE, 1). Ya desusado.

${ }^{461}$ Plegue: forma de presente de subjuntivo del verbo placer.

${ }^{462}$ Hicistes... dijistes: formas antiguas, por hicisteis... dijisteis.

${ }^{463}$ Conocer: reconocer, confesar (DRAE, 7).
} 


\section{CAPÍTULO []$^{464}$}

Yo vine al huerto mio, hermana mía Esposa. Cogí la mirra mía con el mi aroma, comí panal con miel, bebi mi vino con mi leche. Comed, compañeros, bebed y embriagaos, compañeros. Yo duermo y mi corazón vela; la voz de mi querido llama: Ábreme, hermana mía, compañera mía, paloma mia, perfecta mía, porque mi cabezc esta llena de rocío y mi cabello de las gotas de la noche. Desnudéme mi vestidura; ¿cómo me vestiré? Lavé mis pies; ¿cómo los ensuciaré? Mi amado metió la mano por el agujero, y mis entrañas sonaron en mí. Levantéme a abrir a mi amado y mis manos gotearon mirra, que cayó sobre los goznes de la aldaba. Yo abri a mi amado y mi amado se habia ido y se habia pasado; mi ánima se me sale en el nablar de él. Busquélo y no lo hallé, llamélo y no me respondió. Halláronme las guardas que pasaban la ciudad, hiriéronme, tomáronme mi manto, los guardas de los muros. Yo os conjuro, hijas de Jerusalén. que, si halláredes el mi querido, le contéis que soy enferma de amor. ¿Qué tiene el tu amado más que otro amado? ¿Por qué asi nos conjuras? El mi amado, blanco y colorado, trae la bandera entre los millares. Su cabeza oro apurado en fuego; sus cabellos negros, crespos como cuervo; sus ojos como los de las palomas entre los arroyos de las aguas, lavadas con leche, asentadas sobre lo lleno; sus mejillas como hilera de plantas olorosas de los olores de confección; sus labios violetas que destilan mirra derretidi; sus manos rollos de oro llenos de tarsis; su vientre el resplandor del marfil cercado de zafiros; sus piernas columnas de mármol fundadas sobre basas de oro; su casta como la del Libano, escogido como los cedros; su paladar dulce, y todo él deseoso. Este es mi amado, este es mi compañero, hijas de Jerusalén. ¿Dónde fue el tu amado, oh hermosa entre las mujeres? ¿Dónde se volvió el tu querido y buscarlo hemos contigo.

\section{[EXPOSICIÓN]}

Yo vine al huerto mio, hermana mia Esposa. Cogí la mirra mía etc.

En el fin del capítulo pasado convidaba la Esposa a su Esposo [a] que viniese a su huerto a coger de los dulces frutos de él, porque para él estaban en los árboles, y le parecía que serían perdidos si su Esposo no los comía, porque estas persuasiones hace el verdadero amor. Ahora, en el principio de este capítulo, el Esposo, como aquel que mucho ama y desea hacer la voluntad de su querida Esposa, dice que a él le place (de $)^{465}$ venir a su huerto y llamarle suyo, porque por tal le tiene, siendo él y su Esposa una misma cosa; y promete la certeza de su

\footnotetext{
${ }^{464}[\mathrm{~V}]$ : realizamos esta la adición y suprimimos lo que hemos encontrado en el manuzcrito (Quinto) en un intento de homogeneizar los titulos de los capitulos.

${ }^{465}$ (De): como en casos anteriores, realizamos la supresión en base a los usos modernos, pues el infinitivo realiza la función de sujeto, no estando necesitado de preposicion
} 
venida, diciendo: "Yo verné ${ }^{466}$ prestisimo a mi huerto y cogeré la mirra mía con las otra[s] aromáticas flores y resmas olorosas que en el huerto se crían".

$\mathrm{Y}$, porque los que van a los huertos y jardines a holgarse no solamente cogen olorosas flores y hierbas, mas $^{467}$ también suelen comer y llevan viandas y vino, y allá cogen de las frutas que hay; por eso dice el Esposo: "Comeré mi panal con mi miel, beberé mi vino, comeré mi leche". Como si dijera: "Comeremos en este huerto frutas dulcísimas, a las cuales mi Esposa me ha convidado, y panales de miel que allá en el huerto hay, y mucha leche y mucho vino, de manera que nos regocijemos nucho". Y esto es hablando con alegría, como los amigos que conciertan (de ${ }^{468}$ irse a holgar a algún jardín: "Iremos allá y comeremos y regocijarnos hemos y haremos una buena beodeza ${ }^{469 "}$. Que estas palabras se dicen por encarecimiento, no porque ellos vayan con propósito de embeodarse ${ }^{470}$, sino dan a entender cuan regocijados estarán. $Y$, así, pareciéndole al Esposo que ya están en ella, convida a sus compañeros los pastores [a] que coman, beban y se huelguen: "Comed, comed -los dice-, compañeros, comed y bebed hasta embeodaros; alegrémonos mucho en el huerto de mi señora, amiga y compañera, hermana y dulce Esposa".

Y de esta manera el Esposo promete con gran regocijo (de) ${ }^{471}$ venir muy presto, como hemos dicho. Porque el verbo de tiempo pasado declaramos de tiempo venidero, diciendo yo verné -y así los otros: cogi, comí, bebi, cogeré, comeré, beberé- siendo este muy común uso de la Escritura Santa, poner tiempo pasado por futuro, y futuro por pasado. Y esto se ve en las demás promesas que la Divina Palabra hace por sus profetas, para mostrar que son tan ciertas como si estuviesen ya cumplidas; y, así, en los Salmos, las cosas que esperan muchas veces se dicen por tiempo pasado, como es aquello: $Y$ mi ojo despreció a mis enemigos ${ }^{472}$; quiere decir "despreciará". Y que aquí se haya de tomar pasado por futuro está claro porque aún no ha venido el Esposo, $\operatorname{mas}^{473}$ luego abajo viene y llama a la puerta de su Esposa.

Y la repetición del mía, mio tras cada cosa de las que cuenta es señal de amor y regalo, llamando suyas todas cuantas cosas nombra de su Esposa, como acá solemos decir: "Hermano mío, compañero mío, consejero mío". Diciendo leche y vino, panales y miel, a la letra se guarda el decoro y conveniencia de la persona que habla, porque un pastor semejantes comidas usa y con la abundancia de ellas se deleita mucho, como los delicados con sus soberbias comidas.

\footnotetext{
${ }^{466}$ Verné: forma de futuro arcaico.

${ }^{467}$ Mas: equivalente a sino.

468 (De): suprimimos en base a los usos actuales, por realizar el infinitivo la función de complemento directo y no necesitar la preposición.

${ }^{469}$ Beodeza: beodez: embriaguez o borrachera (DRAE).

${ }^{470}$ Embeodarse: emborracharse.

${ }^{471}$ (De): suprimimos en base a los usos actuales, por realizar el infinitivo la función de complemento directo y ro necesitar la preposición

${ }^{472}$ Alusión biblica sin anotación al margen en el manuscrito. Saimo 53, titulado Contra los enemigos.

${ }^{473}$ Mas: equivalente a sinc.
} 
El divino Esposo no tarda mucho al llamar de su Esposa, mas ${ }^{474}$ promete ser prestísimo y ayudar su Iglesia, que este es su venir y coger su mirra y las demás especies de suave olor, las cuales coge él cuando se paga ${ }^{475}$ de las buenas obras de su Esposa, fresquísimo huerto suyo. Y también dice que comerá la miel y panal -que es todo uno- y beberá su vino y leche, y esto será aprobando la Divina Doctrina que en esta Iglesia hay, que es dulcísimo mantenimiento y suavísima bebida de las ánimas; y esto no ha de ser doctrina extraña o ajena, sino la divina, que vino del cielo, y por eso dice mio, mía tantas veces. Últimamente convida a todos sus amigos y compañeros, los pastores y los demás que son de su bando, [a] que de este manjar que a él le agrada y de esta bebida que le sabe bien todos se harten y beban hasta que se embriaguen; porque, teniendo ellos gran cuidado de comer del dulce cibo ${ }^{476}$ y beber suavísimo, como de la doctrina de Dios, se vendrán a embeodar y a estar tan contentos que de otra cosa mundana no curen ${ }^{477}$ ni hagan caso, como suelen los beodos, que olvidan y desprecian todas las cosas y nada les agrada si no es el vino.

Yo duermo y mi corazór vela; la voz de mi amado que llama: Ábreme, amiga.

Se dice del que ama que no vive consigo más de la mitad, y la otra mitad, que es la mejor parte, que vive y está con la cosa amada. Porque, como nuestra ánima tenga dos oficios, uno de criar y conservar el cuerpo mediante las obras que para esto hace -comer, dormir y las demás-: el otro oficio es pensar, imaginar y contemplar, ejercitando la principal parte suya; cuando uno ama, nunca su alma está en él ni en cosa que a él pertenezca, contemplando, pensando ni imaginando, sino en la cosa amada. En aquella sola se emplea, y en el conocimiento y deseo de aquella se ocupa solamente; obra en sí las obras de la vida animal, y estas aun no perfectamente.

[En] esto que hemos así propuesto simplemente sin más filosofar, en ello nos declara la grandeza del amor que en este lugar muestra la Esposa diciendo: Yo duermo y mi corazón vela. Porque dice que, aunque duerme, no duerme del todo ni toda ella reposa, porque su corazón, que no está con ella sino con su amado, está siempre velando con el cuidado. Como quiera que su corazón se haya entregado al amor y servicio de su Esposo, no tiene que ver con ella y, así, no obra juntamente con ella en su provecho. Porque uno querría huir los trabajos del amor, mas el corazón dice: "Yo los quiero sufrir". Dice el que ama: "Grave ${ }^{478}$ carga es esta". Responde su corazón: "De ${ }^{479}$ llevarla tenemos". Se queja el amante [de] que pierde el tiempo, la vida, la esperanza; le da el corazón todo por bien empleado. Y, así, cuando el cuerpo duerme y reposa, entonces está el corazón velando y negociando con las fantasías de amor, recibiendo y enviando mensajes. Y, como el corazón de la Esposa velaba mientras ella dormía, oye con los oídos interiores la voz de su amado, que venía diciendo y prometiendo la presteza de su llegada al huierto.

\footnotetext{
${ }^{474}$ Mas: equivalente a sino.

${ }^{475}$ Pagar (prnl.): prendarse, aficionarse (DRAE, 5)

${ }^{475}$ Cibo: cebo. Forma antigua.

${ }^{477}$ Curar: Con la prep. de, cuidar de, poner cuidado (DRAE,2)

${ }^{478}$ Grave. utilizada en el sentido etimológico del latin gravis: pesado.

${ }^{479} \mathrm{De}$ : lo normal actualmente seria que. Se trata de una perifrasis obligativa antigua.
} 
Estando pues el corazón en esta centinela velando, despierta a la Esposa para que sienta la venida de su Esposo; y, al punto que ella despide el sueño, el Esposo llega y llama a la puerta, cuya voz ella bien conoció. Tocando, llama: "Ábreme, hormana mía carísima ${ }^{480}$, compañera mía, como las palomas suelen serio; ya sabes que eres ini paloma y me debes todo amor y toda voluntad. Ábreme, bella mía, perfecta en beldad, belleza. sólo para mí nacida". Y en este replicar de mía muestra el afecto con que la llama para moverla a abrir a aquel de quien tanto es amada. $Y$, porque no puede sufrir quien ama (de $)^{481}$ ver padecer a su amado, $(y)^{482}$ dice: "Cata ${ }^{483}$ que no puedo estar fuera, que hace muy gran sereno y cae un gran rocío del cual tengo llenos mis cabellos. No es razón que tú estés en la cama a tu placer y te tardes de ${ }^{484}$ abrir a tu amado, dejándolo mojar y maltratar del frío y sereno.

Estando la Esposa durmiendo en la flaqueza de su carne, no teniendo tanto cuidado de las cosas espirituales cuanto conviene -que esto significa el dormir-, dice y confiesa que está su espíritu velando. Porque, enamorado, el espíritu de su Dios siempre querría agradarie y estar en vela concitándose en buenos pensamientos y en obrar la ley del señor; y, por eso, conoce la voz que lo llama y amonesta, y, así, tiene cuidado de despertar [a la parte] exterior que está durmiendo, y esto es muy consonante ${ }^{485}$ con aquello que dice San Pablo: En mi siento el querer, mas no hallo el acabar de lo bueno ${ }^{486}$; pues, para remedio de esta imperfección y despertar del todo de su sueño, es menester abrir al Esposo, que está a la puerta llamando siempre y llama con gran deseo [de] que le abran y cuenta y muestra las fatigas que ha sufrido viniendo a ver a su Esposa, porque ${ }^{487}$, movida con esto y con el regalo de su amorosa voz, le abra y, viéndole, le perfeccione todo aquello que le falta y la haga del todo santa sin mancilla, ni tacha, ruga, ni otro vicio de imperfección; que este bien tan entero no se puede alcanzar si no se admite $\mathrm{el}^{489}$ Esposo que llama siempre.

Desnudéme mi vestidura; ¿cómo me la vestiré?. Lavé mis pies; ¿cómo los ensuciaré?

Aquí se pinia muy al vivo un melindre, o como le llamaremos ${ }^{489}$, que acaece y es muy común a las mujeres, haciéndose esquivas donde no es menester; $y$, muchas veces, deseando

\footnotetext{
${ }^{480}$ Caro: ama... rido (DRAE, 4).

${ }^{481}$ (De): suprimimos, en base a ios usos actuales, por realizar el infinitivo la función de complemento directo y no necesitar la preposición.

${ }^{482}(Y)$ : suprimimos la conjunción, dado que la proposición que la precede no está cosrdinada con la anterior, sino que es subordinada de ella.

${ }^{483}$ Catar: mirar

${ }^{484} \mathrm{De}$ : lo habitual actualmente seria en

${ }^{485}$ Consonante: que tiene relación de igualdad o conformidad con otra cosa, de la cual es correspondiente y correlativa (DRAE, 4) Actualmente es más habitual la utilización de este término en otros usos más alejados que este del original sentido etimológico.

${ }^{486}$ En el manuscrito, Carta a los Romanos, 7. Concretamente se trata de Carta a los Romanos (7, 17-20).

${ }^{487}$ Porque: sentido -laramente finai.

${ }^{488}$ El: al.

${ }^{489}$ Llamaremos: uso de futuro donde actualmente se utilizaria si presente de subjuntivo. Este uso del futuro se da actualmente en otras lenguas románicas.
} 
mucho una cosa, $(y)^{490}$ cuando la tienen a la mano fingen no quererla o que les sea enojosa. Ha la Esposa deseado que su Esposo viniese y dicho que sin él no puede una hora vivir y rogándolo ${ }^{491}$ que venga y no la deje sola y despertado con gran alegría a la voz del que venía; y ahora, en sintiéndolo llamar, se ensoberbece y rehúsa $(\text { de })^{492}$ abrirle y se hace delicada ${ }^{493}$ por hacerlo penar y ganar aquella victoria más de él. Y dice, poniendo frías escusas: "Me desnudé mi camisa; ¿cómo la tornaré a vestir, que estará fría? Me lavé los pies poco ha para acostarme; los tengo ahora de ${ }^{494}$ ensuciar poniéndolo[s] en el suelo?" Es gentil trueque este: que, viniendo el Esposo a ella cansado y mojado, habiendo pasado el sereno y mal trato de la noche, $(y)^{495}$ ella no quiere sufrir por ella ${ }^{496}$ la camisa fria.

Mas, como el Esposo ve que ella se tarda, procura con sus fuerzas abrir la puerta metiendo la mano por aigún agujero de ella para probar de ${ }^{497}$ alcanzar a la aldaba -o cerradura- y abrir; y esto sintiendo ella, dice que se trobaron ${ }^{498}$ las entrañas dentro en su pecho; o fuese por el amor -que no la consintiese más rebasar ${ }^{499}$, entendiendo con cuánto deseo de verla su Esposo venía, pues que con las palabras usaba de fuerzas-, o fuese por vergüenza de lo pasacio -pareciéndole ser ya gran descomedimiento suyo-, va poco en ello. Mas mejor razón es la primera, a nuestro juicio: que la acusación que amor le puso dentro causó aquella turbación en sus entrañas. Y luego dice que saltó de la cama a abrirle y que las manos le corrían mirra tanta que el pestillo de la cerradura se untaba cuando ella asía de él para abrirle. Y, en decir así, da a entender con cuánta gana le iba a abrir, que todo le sucedía bien y las manos con que le quería abrir, con el regocijo que ella llevaba, le olían a mirra purísima y suavísimamente, y también olía la cerradura tocada de las manos. Como acá solemos decir cuando uno hace la cosa bien hecha y con voluntad, no parece sino que mil gracias tiene en las manos, que tan gracioso le sale todo cuanto hace. $O$ también por ventura significa que ella se hubiese untado con mirra por oler bien a su Esposo al tiempo que le abriese, como muchas desposadas suelen hacer, perfunarse $\mathrm{y}$ traer consigo olores.

En el espiritu, se ve claro que muchas veces, llamándonos el Esposo, el cual tanto ha pasado y sufrido por esta su Esposa, no queremos abrirlo, estando contentos en la cama de nuestra

\footnotetext{
${ }^{490}(Y)$ : suprimimos la conjución dado que la proposición de gerundio que la antecede no se coordina con lo que sigue, pues es complemento oracional suyo

${ }^{491}$ Rogándolo: esta forma de gerundio rompe la forma sintactica. Podria pensarse que se trata de un error: rogándolo en lugar de rogádolo. En este caso, nos hallariamos ante un flagrante caso de loismo, que. no obstante, no resultaria extraño, segin el uso de los pronombres que venimos observando a lo largo del texto.

${ }^{492}$ (De): suprimimos, en base a los usos actuales, por realizar el infinitivo la función de complemento directo y no necesitar la preposición.

${ }^{493}$ Se hace delicada: expresión correspondiente a la actual se hace la delicada.

${ }^{494}$ Tengo... de: perifrasis obligativa ya desusada

${ }^{495}(Y)$ : suprimimos la conjunción, dado que la prc.posición que la precede no está coordinada con la anterior, sino que es subordinada de elia.

${ }^{496}$ Ella: clara confusión: ella en lugar de él.

${ }^{497} \mathrm{De}$ : Io habitual actualmente seria $a$.

${ }^{498}$ Trobaron: turbaron

${ }^{499}$ Rebasar: probablemente usado en el sentido de la expresión coloquial moderna pasarse.
} 
regalada vida, y nos parece grave cosa sufrir un poco de frío, de turbaciones y cruz por él, y juzgairius por insufrible una poca de afrenta ${ }^{500}$ o deshonra vana, un dar que decir a las gentes, pareciendo que sea una gran suciedad aquella para nuestros pies, que los tenemos lavados a nuestro parecer; los cuales pies son los apetitos y deseos de riquezas y honra del mundo, y no queríamos ensuciarlos con afrentas y deshonras ni otra cosa, que tal nos pareciese más el Esposo, que todas las cosas prueba por ver a su Esposa y santificarla con su presencia. Mete la mano por los agujeros de esta carnal puerta que no quiere abrírsele para abrir por fuerza; y, así, algunas veces, con la fuerza de los castigos, enfermedades y aflicciones, nos hace sentir y conocer nuestro error. Y, siendo conocido y habiendo ya caído en él, va la Esposa a abrirle con gran voluntad, llamando su socorro y pidiendo su favor, acusando juntamente una negligencia.

Yo abri a mi amado y mi amado se habia ido y era ya pasado.

A muy buen tiempo el Esposo usa del palacio ${ }^{501}$ con su Esposa, porque, viendo que ella al principio no le quiso abrir, dándole cuasi a entender que no le había menester y que sin él estar podía, él probó abrir la puerta por lugar donde ella estaba; mas, como la siıtió levantada y que le venía a abrir, le quiere pagar la burla. Como quien dijese: "Vos queréis darme a entender que podéis estar sin mí; pues yo os haré entender cómo yo me puedo más sufrir sin vos que vos sin mí". Y por esto se ausenta luego de ahí, no aborreciéndola, sino castigándola y para ${ }^{502}$ mayor prueba de su amor de ella y hacerla penar un raio deseando y temiendo, para que más gusto le sea después la presencia de su Esposo y [para] escarmiento viendo cuán mal le va con su ausencia.

Dice pues la Esposa: "Yo abri a mi amado y no le hallé a la puerta como yo pensaba, porque él era ido y pasado de largo". Bien se entiende la tristeza con que estas palabras dice la Esposa, como aquella que justaniente se hallaba triste y corrida ${ }^{503}$ de su descuido. Y, así, parecen las palabras como de asombrada y medio fuera de sí, con una tan gran congoja; y la representación de su decir que se habia ido y que se habia pasado denota esto, como quiera que una persona afligida suele hablar dos y tres y más veces una misma cosa, y callar otras que había de decir. Y, así, con grande angustia, dice luego: Mi ánima se me salió en el hablar de él. Quiere decir: "¡Ay, triste de mí! Que, cuando él hablaba, no sé qué movimiento en mí hacian sus palabras que el alma se me salía y se me iba tras él. Parece que adivinaba aquesto. Yo me iré y le buscaré y le daré voces, hincharé el aire del sonido de su nombre porque ${ }^{504} \mathrm{me}$ responda y venga a mí; mas, jay!, que, procurándolo, no lo hallo y, llamándolo, no me responde". De esta manera se ha de entender la letra.

\footnotetext{
500 Una poca de afrenta: lo habitual en este tipo de construcciones partitivas es que el indefinido aparezca invariablemente terminado en $o$, sin concordar con el sustantivo que a èl se enlaza mediante la preposición. En este caso se da una atracción por parte del sustantivo, de modo que el indefinido aparece en femenino.

${ }^{501}$ Usa del palacio. Dado que se trata de nuevo de un pasaje literal al del Comentario seguin la letra, transcribimos a continuación la nota que al respecto escribe el $\mathrm{P}$. Merino: "El impreso y algunos manuscritos, usa del tanto por tanto; pero nuestro manuscrito con otros dos, dicen, usa del palacio, y equivale á lo mismo".

502 Castigándola y pura: encontramus aqui un significativo caso de construcción con la figura denominada variatio, coordiándose proposiciones de gerundio con otras encabezadas con la preposición para (construida con sustantivo y con infinitivo) y con la conjución paia que.

${ }^{503}$ Corrido: avergonzado, confundido (DRAE, 5). En desuso.

${ }^{504}$ Porque: valor rinal.
} 
Busquélo y no lo hallé, llamélo y no me respondió.

Por el uso de la Sagrada Escritura, que ya dijimos mudar tiempo por tiempo, cuenta juntamente las desgracias buscando a su Esposo. Que, andando de una parte a otra por las calles de dentro del pueblo y por defuera, [se] encontraron con ella los guardas que de noche guardan y rodean la ciudad; y, como entre los tales nunca faltan galfarros ${ }^{505}$, capeadores y ladrones, dice que la hirieron dándole algunos golpes, como a mujer sola y sin amparo de quien la defendiese, y esto así que ella, mampaiándose ${ }^{506}$ con los brazos o huyendo, dejase caer el manto o mantellina que encima llevaba, o alguno por detrás se lo quitase. Y, así, se queja y dice que las guardas de los muros socorrieron a su pasión con esta buena obra; $y$, con todo eso, maltratada, fatigada y robada, no [se] cansa de buscar a su Esposo, que le duele más que todo el gesto.

$\mathrm{Y}$, no habiéndole hallado por su llamar y diligencia, ruega a las vecinas de Jerusalén que se le ayuden a buscar, diciéndoles: "Yo os conjuro, yo os ruego, mujeres de Jerusalén, que, si halláredes por allá [a] aquel que tanto amo, le contéis que yo estoy enferma de amor". No les dice "que voy buscándolo, que me han maltratado andando en su busca, que no le puedo hallar o que venga a mí", sino sólo "que estoy trabajada ${ }^{507}$ de amor", porque en sola esta razón las dio a ellas y a él a entender todo lo de arriba y mucho más, y conocía que su Esposo no deseaba de ella otra cosa, y este solo es el cebo con que prestísimo le traerá a su anzuelo. Maravilladas, y con razón, las mujeres de ver que una doncella tan fresca a tal hora anduviese tan ansiada procurando un amado suyo, movidas a compasión juntamente con admiración, le preguntan qué ventaja tenga su amado a los de las orras doncellas por que ${ }^{508}$ ella se ponía ${ }^{509}$ por él a lo que otra no haría, sreyendo que esto era o por la grandeza del amor de esta doncella o por locura y desatino suyo, y le dicen: "¿Qué tiene tu amado más que otro amado, hermosa sobre las mujeres? ¿Qué tiene tu amado más que otro amado? ¿Por qué así nos preguntas?"

En la sentencia escondida de este lugar se muestra cómo el divino Esposo, muchas veces habiendo llamado con gran ahínco a la puerta de su Esposa, y ella, por descuido o negligencia humana, no queriéndole abrir, la deja apartando de ella un poco la presencia de sus consolaciones y esfuerzos, para que ella más lo desee conociendo cuán flaca es y cuán poco vale sin él, $y$, así, lo busque con la agonía que aquí muestra llamándole a voces, andando diligente en su pesquisa. $\mathrm{Y}$, andándolo a buscar, [se] encuentra con las guardas y centinelas que guardan de noche la ciudad, que son los que en tiempo de las tinieblas de ignorancia presidian y los que so celo y nombre de religiosos, andaii en tinieblas, no entendiendo ni enseñando el verdadero culto y honra de Dios, como ya arriba se ha declarado. Y estas

\footnotetext{
${ }^{505}$ Galfarro: hombre ocioso, perdido, mal entendido (DRAE, 3).

${ }^{506}$ Mamparar: proteger, amaparar. (DRAE). Forma antigua.

${ }^{507}$ Trabajado: ccnsado, molido de trabajo, por haberse ocupado mucho tiempo o con afán on él (DRAE, 2.). Ver nota 54.

${ }^{508}$ Por que: puede haber aqui una doble interpretación. Nosotros presentamos este que como un pronombre relativo, aunque no es descartable que se trate de por qué, forma interrogativa.

${ }^{509}$ Poner (prnl.): exponer a uno a una cosa desagradable o mala (DRAE, 16).
} 
maltratan a la Esposa con sus vanas y ruines doctrinas, y le quitan de encima cuanto ellos pueden el velo de la fe que $\operatorname{los}^{510}$ cubre.

Conociendo ella el mal tratamiento de estos y huyendo de ellos, porfía todavía por hallar a su Esposo y pregunta a las hijas de Jerusalén, que son aquellos que verdaderamente pertenecen al pueblo de Dios -cuales son los verdaderos de la santa ley, los profetas y muy santos enviados- $y$ les ruega que le encomienden el gran amor y aíición que a su Esposo tiene y lo que por su ausencia padece. Y, porque es menester que ella confiese y manifieste las grandezas de su Esposo, las cuales la han inducido a amarlo y procurarlo, para que se vea su amor y procura al verdadero divino Esposo, le preguntan que les diga las señas para ver por quién se aflige tanto; porque, si es [por] aquel que solo merece ser amado, estará bien, trae buen negocio y ayudárselo han a buscar; $y^{511}$, si es por otro Dios vano, frío y sin virtud, o por otra cosa que ella se haya fingido para amarla, dejarla $v^{512}$. Mas eila, cumo en esto no puede errar, da muy buenas señas de su Esposo, las cuales oirernos luego.

\section{El mi amado, blanco y colorado, trae la bandera sobre los millares.}

Da al principio la Esposa señas de su Esposo generalmente, diciendo que es bianco $y$ colorado; después va señalando las partes de su belleza cada una en su lugar. Dice pues: "Sabed, hermanas, hijas de Jerusalén, que el mi amado es blanco y rojo, porque de lejos le conozcáis con la luz de estos colores, los cuales son tan perfectos en él que entre millares trae la bandera de la blancura y frescura de todos los hombres. En esto porque tengáis más noticia de él si os acercáderes a él, su cabeza es muy gentil, redonda y proporcionada, como hecha de oro acendrado, sin ninguna falta ni tacha". Esto quiere decir "cabeza de oro", porque es costumbre de las lenguas esta ${ }^{513}$, para significar una cosa perfecta y agraciada, decir "hecha es de oro". Y por esto dice la Esposa que no por los cabellos que sean rubios ${ }^{514}$, como luego vemos, (que $)^{515}$. Porque en todas las tierras orientales y en todas las tierras calientes tienen por galano el cabello negro, como hasta hoy se precian de él los moros; y por esto dice "sus cabellos crespos y negros y barba negra", que los rubios, por ser dos colores contrarios, que el uno da luz al otro.

Sus ojos son como los de las palomas en los arroyos de las aguas, con leche lavadas, asentadas sobre lo lleno.

Ya dijimos que gran parte de la hermosura consiste en los ojos, [en] los cuales la Esposa pintaia las señas de su Esposo por una semejanza que le está muy bien y dice más que con paiabras pudiera declarar. Las palomas, principalmente las tripolinas, de que arriba decimos

\footnotetext{
510 Lus: st:ponemos que se trata de un error, pues ese velo debe ser de la Esposa, debiendo, consecuentemeite, aparecer aqui la forma la.

${ }^{511} Y$ : equivalente a pero

512 Dejarla van: se trate de la forma, aun no totalmente configurada, de ia perifrasis moderna ir a + infinitivo.

${ }^{513}$ Esta: se anticipa en el demcstrativo la proposición de infinitivo que aparece después.

${ }^{514}$ No... rubios: construcción extraña a los usos actuales, en los que se prefiere no porque..

515 (Oue): suprimimos esta conjunción, dado que no encaja en la construcción sintáctica. Probablemente se deba a un error del copista, pues, a la vista del pasaje paralelo del Comentario segin la letra, parece ser que faltan algunos elementos de la oración. Transci ibimos a continuación este pasaje: "Porque es cosa usadia en todas las lenguas, para decir de cualquiera cosa que es perfecta y agraciada, decir que es hecha de orc; y por eso lo dice la Esposa aqui y no por ser rubios los cabellos, que, como veremos, eran negros los del Esposo".
} 
mención ${ }^{5 i 6}$, son de bellísimos ojos; y, como ellas suelen bañarse muchas veces, cuando salen del agua les centellean en gran medida, y los que las comparan para los que son aficionados suelen con la mano mojada fregallar ${ }^{517}$ los ojos. Y deja ${ }^{518}$ que reluzcan y relampagueen de los ojos corazón. Fascinada por eso, dice ía Esposa que son los ojos de su Esposo hermosos como los de las palomas cuando más hermosos se les ponen, que es cuando se bañan.

Y lo que dice adelante: lavados en leche. No entiendo yo que las palomas bañen los ojos en leche, porque la tal cosa no he oído, leído ni visto, ni creo que tal 'e use, siro [que] alude a la blancura de su Esposo, como si dijese: "Es su rostro tan blanco que no parecen aquellos sus ojos sino que andan bañados en leche". Y luego, para mostrar que no los tiene sumidos ni salidos afuera, dice que están asentados sobre lo lleno, quiere decir, sobre una igualdad del rostro, que no tiene hinchadas las mejillas y lo otro sumido y bajo, $(y)^{519}$ sino muy graciosamenie lleno todo su rostro; y sobre aquelia conveniente igualdad se asientan sus ojos. De manera que no solamente los loa por el color, mas $^{520}$ también por la postura ${ }^{52 !}$ y sitio de ellos, y la gracia y proporción que en ellos tiene.

\section{Sus mejillas como hilera de plantas olorosas.}

Prosigue todavía la Esposa señalando en particular la belleza de su Esposo, y dice de las mejillas, por las cuales entendemos todo el rostro. Y testifica que es $\tan$ bello y tan agraciado y asentado que no parece sino unas eras muy parejas de plantas olorosas, de las cuales se cogen aceites y gomas de confección para vender, las cuales plantas, como son muy estimadas, son criadas con gran regalo en los jardines y están puestas muy iguales y por gentil orden. $Y$ de estas plantas hay gran abundancia en tierra de oriente, donde esta Esposa habla. Los jardines donde se crían tienen muy graciosa vista con la parejura y hermosura de ellas. Tan parejo y gracioso dice que es el rostro de su Esposo. Y después dice que sus labios son unas violetas o flores que dan mirra. Y entiendo en esto dos cosas. Lo uno, que son delicados y frescos y colurados como violetas, que son de color rojo que tiran a granos de granada; $y$, así, hay una especie de violetas alhelíes. Y, demás ${ }^{522}$ de esto, dice que son graciosos en su hablar y menearse, que parece que de ellos mana una muy suavísima mirra, tal que enamora en oírlo. Largo dice de las manos.

Es de loar y considerar el gran artificio con que la rústica Esposa loa a su Esposo; porque los que mucho quieren encarecer una cosa, alabándola y ủeclarando sus propiedades, dejan de

\footnotetext{
${ }^{516}$ Decimos mención: suponemos que se trata de un nuevo error, protaiblemente debido al parecido entre las formas decimos e hicimos, forma esperable en este contexto tanto por su sentido como por el tiempo verbal.

517 Fregallar: fregar.

${ }^{518} Y$ deja: corno podrá observarse parece producirse un salto en el discurso, tal vez error de copista.

${ }^{519}(Y)$ : suprimimos la conjunción por ser claramente sobrante en ese contexto sintáctico.

${ }^{520}$ Mas. equivalente a sino.

${ }^{521}$ Postura: podria referirse a su situación o bien al siginificado antiguo de aaorno de algunas cosas (DRAE, 11).

${ }^{522}$ Demás: ademá.
} 
decir los vocablos llanos y propios de las propiedades y dicen los notores ${ }^{523}$ de ias cosas en quien más perfectamente se halla aquella cualidad, y esto ensarece más la cosa y tiene más gracia. Como lo hace aquel gran poeta toscano ${ }^{524}$ que, habiendo de decir y alabar los cabellos, los llama "oro"; a los labios "rosas" o "grana"; los dientes "perlas"; los ojos "luces" o "lumbres" o "estrellas"; y este bello artificio se guarda mucho más en la Escritura Sagrada que en otra ninguna del mundo. Y así vemos que aqui procede la Esposa de aquesta manera; porque, diciendo de los ojos que son de paloma, dice más que si dijera que eran hermosos; y las mejillas como las hileras de plantas, las loa más que si dijese "parejas, iguales y graciosas".

Y, por el mismo tenor, de las manos de su Esposo dice que son unos rollos de oro llenos de tarsis, alabando la gracia y cornposición de ellas, por ser largas, luengas ${ }^{525}$, y los dedos rollizos tan lindos como si fuesen torneados de oro. Y la piedra de tarsis es un poco como entre roja y blanca, según que un hebreo antiguo llamado Abencerro la pinta. Y, conforme a esto, da a entender la Esposa las uñas en que se rematan los dedos de las manos, que son un poco rojas y relucientes, como piedras preciosas de tarsis. Y, por tanto, las manos, en su hechura y con sus uñas, serán como rollos de oro rematados en tarsis; que, aquí, solamente, en decir de las manos rollos de oro, habla de la hechura de las manos y gracia de ellas; que del color ya ha dicho que son blancas cuando arriba dijo: Mi Esposo es blanco y colorado. Luego c" ze, por el mismc estilo y semejanza de hablar:

\section{Su vientre es resplandor de marfil, encaiados zafiros ${ }^{526}$.}

Quiere decir: "Su pecho y vientre -que toma la parte por el todo- es ${ }^{527}$ blanco y resplandeciente como un marfil muy polido ${ }^{528} ; y$, como juntamente con su blancura es rojo, no parece sino una perla de marfil donde estén encajados algunos zafiros, que son piedras de valor bermejas".

Y luego desciende a dar señas de las piernas, las cuales, con sus pies, sobre que se sustenta tode el cuerpo, dice que son unas columnas de mármol blanco, hechas con gentil medida y proporción; que lo grueso corresponde con lo aito de ellas, de la manera que las columnas antiguas lo eran. Y estas columnas están muy bien asentadas sobre las basas de oro que son los pies, hechos en muy gentil proporción, redondos -como deben ser- y muy agraciados, como si fueran aposta hechos de oro; $y$ tan recios y incorruptibles como sueie ser el oro. Porque el edificio que tuviese (en) $)^{529}$ las basas de las columnas de oro será ${ }^{530}$ más durable, por causa que

\footnotetext{
${ }^{523}$ Notores: nombres.

${ }^{524}$ Aquel gran poeta toscano: se refiere a Petrarca

${ }^{525}$ Luengo: largo. Forma antigua.

${ }^{526}$ Encajados zafiros: consirucción participial absoluta, según el uso latino.

$: 27$ Es: en singular, concuerda únicamente con el más cercano de sus sujetos.

${ }^{528}$ Polido: puiido.

$52{ }^{\circ}$ En: suprimimos esta pieposición que rompe la sintaxis de ta oración.

${ }^{530}$ Será: este futuro imperfecto de indicativo resulta aqui inadecuado si tenemos en cuerta los tiempos de los otros verbos de la oi ación. Lo esperzble seria un condicional simple.
} 

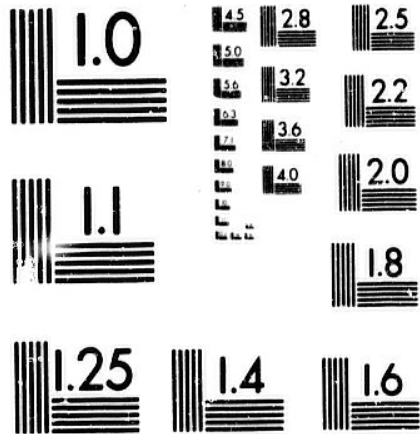

MICROCOPY RESOLUTION TEST CHART

NATIONAL BIJREAU OF STANDARDS STANDARD REFERENCE MATERIAL 1010a (ANSI and ISO TEST CHART NO. 2) 
decir los vocablos llanos y propios de las propiedades y dicen los notores ${ }^{523}$ de las cosas en quien más perfectamente se halla aquella cualidad, y esto encarece más la cosa y tiene más gracia. Como lo hace aquel gran poeta toscano ${ }^{524}$ que, habiendo de decir y alabar los cabellos, los llama "oro"; a los labios "rosas" o "grana"; los dientes "perlas"; los ojos "luces" o "lumbres" o "estrellas"; y este bello artificio se guarda mucho más en la Escritura Sagrada que en otra ninguna del mundo. $\mathrm{Y}$ así vemos que aquí procede la Esposa de aquesta manera; porque, diciendo de los ojos que son de paloma, dice más que si dijera que eran hermosos; y las mejillas como las hileras de plantas, las loa más que si dijese "parejas, iguales y graciosas".

$\mathrm{Y}$, por el mismo tenor, de las manos de su Esposo dice que son unos rollos de oro llenos de tarsis, alabando la gracia y composición de ellas, por ser largas, luengas ${ }^{525}$, y los dedos rollizos tan lindos como si fuesen torneados de oro. Y la piedra de tarsis es un poco como entre roja y blanca, según que un hebreo antiguo llamado Abencerro la pinta. Y, conforme a esto, da a entender la Esposa las uñas en que se rematan los dedos de las manos, que son un poco rojas y relucientes, como piedras preciosas de tarsis. Y, por tanto, las manos, en su hechura y con sus uñas, serán como rollos de oro rematados en tarsis; que, aquí, solamente, en decir de las manos rollos de oro, habla de la hechura de las manos y gracia de ellas; que del color ya ha dicho que son blancas cuando arriba dijo: Mi Esposo es blanco y colorado. Luego dice, por el mismo estilo y semejanza de hablar:

Su vientre es resplandor de marfil, encajados zafiros ${ }^{526}$.

Quiere decir: "Su pecho y vientre -que toma la parte por el todo- es ${ }^{527}$ blanco y resplandeciente como un marfil muy polido ${ }^{528} ; y$, como juntamente con su blancura es rojo, no parece sino una perla de marfil donde estén encajados algunos zafiros, que son piedras de valor bermejas".

Y luego desciende a dar señas de las piernas, las cuales, con sus pies, sobre que se sustenta todo el cuerpo, dice que son unas columnas de mármol blanco, hechas con gentil medida y proporción; que lo grueso corresponde con lo alto de ellas, de la manera que las columnas antiguas lo eran. Y estas columnas están muy bien asentadas sobre las basas de oro que son los pies, hechos en muy gentil proporción, redondos -como deben ser- y muy agraciados, como si fueran aposta hechos de oro; y tan recios y incorruptibles como suele ser el oro. Porque el edificio que tuviese (en) $)^{529}$ las basas de las columnas de oro será ${ }^{530}$ más durable, por causa que

\footnotetext{
${ }^{523}$ Notores: nombres.

${ }^{524}$ Aquel gran poeta toscano: se refiere a Petrarca

${ }^{525}$ Luengo: largo. Forma antigua.

${ }^{526}$ Encajados zafiros: construcción participial absoluta, según el uso latino.

${ }^{527}$ Es: en singular, concuerda únicamente con ei más cercano de sus sujetos.

${ }^{528}$ Polido: puliaio

${ }^{529}$ En: suprimimos esta preposición que rompe la sintaxis de la oración.

${ }^{530}$ Será: este futuro imperfecto de indicativo resulta aqui inadecuado si tenemos en cuenta los tiempos de los otros verbos de la oración. Lo esperable seria un condicional simple.
} 
no se gastaría el fundamento ${ }^{531}$ con la humedad del suelo ei tiempo andando ${ }^{532}$, como vemos que se gasta el mármol; y, demás ${ }^{53.3}$ de esto, que ${ }^{534}$ las basas estarían siempre limpias, por ser el oro de su naturaleza limpio y que cada vez luce más. Por esto apoda las piernas de su Esposa ${ }^{535}$ a las columnas con sus basas.

Habiendo loado a su Esposo por toda su persona, y después señalando su belleza por sus partes, desde la cabeza hasta los pies, torna, como quien le parece que ha dicho poco, a comprender en breves palabras lo que ha publicado, y aun más, diciendo: "Es la vista de mi Esposo tan gentil, tan varia su hermosura, $y$ tanto tiene que mirar, que no parece sino el monte Libano, donde hay muy bellísimas plantas y diversas, que nunca la vista las acaba de abrazar todas. Y su estatura es tan graciosa y escogida entre los otros amados, como entre los árboles los cedros. Y las palabras que habla y salen de su paladar son dulcísimas. Y, por concluir, amigas, yo os digo que todo mi Esposo, cuanto él es, que ${ }^{536}$ no es otra cosa sino unos deseos". Quiere decir no hay en él cosa que no sea bellísima y digna de ser sumamente amada, deseada y procurada de quien le falta, porque el deseo no es otra cosa sino un apetito y codicia de las cosas que, conociéndolas por buenas, nos faltan. "Y así veréis, amigas, hijas de Jerusalén, si tengo razón de $\mathrm{e}^{537}$ desear a mi amado y gentil compañero, siendo tal cual os lo he pintado.

Viendo las dueñas la grandeza de la beldad que la Esposa ha contado de su Esposo, por lo cual $^{538}$ lo ama, desea y procura con gran ansia, $(y)^{539}$ les parece que tiene razón en buscarlo. Y, así, no la reprenden ni aconsejan que se torne a su casa; antes, la incitan a que lo procure y quieren ellas, movidas de compasión y también enamoradas de tan gran hermosura, irlo a buscar con ella, y le preguntan que hacia dónde haya ido, [a] qué parte tiene ella entendido haber su camino.

¿A dónde fue tu amado, oh bellisima entre las mujeres? ¿Hacia dónde se volvió tu amado y buscarlo hemos contigo?

Declarando [en] cuanto a la letra el sentido de las señas que la Esposa daba para conocer a su Esposo, declaremos ahora lo que parecen significar al espíritu del divino Esposo. Y lo primero, por la blancura entendemos la luz pura y divina claridad de Dios, y su Sagrada Doctrina y sabiduria, [a] la cual llama la Escritura "blancura de luz eterna", y San Juan dice

\footnotetext{
${ }^{531}$ Fundamento: esta acepción de fundamento, en el sentido de cimientos de un edificio, es poco usada actualmente.

${ }^{532}$ El tiempo andando: construcción de participio absoluto.

${ }^{533}$ Demás: además.

${ }^{534}$ Que: podemos pensar, en principio, que se trata de una proposición completiva, pero no parece depender de ningun verbc.

${ }^{535}$ Esposa: claro error, pues se está tratando del Esposo.

${ }^{536} \mathrm{Que}$ : retoma la construcción completiva comenzada poco antes.

${ }^{537} \mathrm{De}$ : lo habitual actualmente seria en.

${ }^{538}$ Lo cual: en lugar de esta forma neutra, que se supone engloba el contenido de toda la oración anterior, pareceria más lógica la aparición de la cual, cuyo antecedente seria la grandeza de la beldad.

${ }^{539}(Y)$ : surrimimos la conjunción, ptes la proposición anterior no se coordina con la que aqui comienza, sino que es subordinada suya.
} 
también que Dios es luz en el cual ningunas tinieblas hay ${ }^{540}$. Y este Esposo es colorado por la humana carne, en la cual padeció la muerte para remedio de esta su Esposa. Y, por esto, decía Isaías $^{541}$ : ¿Quién es este que viene de Edom, teñidas sus vestiduras de borneth ${ }^{542}$ ? ¿Por qué traes bermeja tu vestidura $?^{543} \mathrm{Y}$ esta mezcla de blanco y rojo está muy clara en Cristo, el cual dice la Esposa que entre mil millones es escogido, porque él es solo al que a tanta perfección de blancura, luz y divinidad y a tan grande exaltación de humanidad pudo llegar aquesta, ninguno ớro por ser hijo de Dios; y de cuyo cumpliento y abundancia todos recibimos.

Demás ${ }^{544}$ de esto, dice que la cabeza de su Esposo es fuerte y bien hecha comc oro recio y durable, dando a entender la fortaleza grande y la pureza de la cabeza de Cristo, que es Dios, como dice San Pablo ${ }^{545}$, y también significa la pureza del entendimiento divino. Y así parece que aquí lo quiere notar por el loor de los cabellos de esta cabeza, que, como por la Escritura hemos visto, son los pensamientos y juicios y ordenaciones que del entendimiento salen, los cuales en el Esposo son hermosísimos y altísimos, que los hombres no los pueden escudriñar ni alcanzar; por eso los llama encrespados y oscuros o negros. De estos decía David: En tus pensamientos no hay semejante a $t^{546}$; y en otro lugar: Tus juicios, señor, son un hondo altísimo $^{547}{ }^{548}$. Quiere decir: "Tus pensamientos son ojos del Esposo que se parecen a los de la paloma; son sol [en] ${ }^{549}$ el juicio suyo, el cual es simple, puro y sencillo, y sin ninguna mezcla de perversidad, sino de suyo claros y bellos ${ }^{550}$, como los de la paloma bañada". Porque los juicios de este Esposo salen y proceden de la abundancia del Espíritu Santo. Y los ojos son figura del juicio, porque, así como con los ojos vemos y acertamos con las cosas de fuera, así con el juicio juzgamos y escogemos el camino para donde nos conviene atinar, y este símbolo y su prueba ya se ha[n] visto arriba. Y, como las mejillas y rostro del hombre es ${ }^{551}$ aquella parte por la cual es más conocido, de la misma manera aquí las mejillas del alto Esposo son sus criaturas, que nos lo muestran y dan testimonio claro de él para que lo conozcamos, como él mismo lo dice por San Juan ${ }^{552}$.

\footnotetext{
${ }^{540}$ En el manuscrito, San Juan, 1. Concretamente, se trata de San Juan (1, 4-5).

${ }^{541}$ Isaias: en el manuscrito aparece con la abreviatura Esai.

${ }^{542}$ Borneth: purpura.

${ }^{543}$ Alusión biblica sin anotación al margen en el manuscrito. Isaias $(63,1-2)$

${ }^{544}$ Demás: además.

${ }^{545}$ En el manuscrito, I Corintios. Concretamente se trata de I Corintios (12, 12-26).

${ }^{546}$ En el manuscrito, salmo 39 (40). El titulo de este salmo es Gratitud, celo, síplica.

${ }^{547}$ Altisimo: se puede apreciar aqui el dcble sentido que en latin tenia altus, correspondiente a los conceptos castellanos de alto y profundo.

${ }^{548}$ En el manuscrito, salmo 35 (36). El titulo de este salmo es Maldad humana y bondad divina.

[En]: el sentido y la estructura del texto entre comillado no están nada claros. Creemos que esta preposición puede arrojar un poco de luz.

${ }^{550}$ Ciaros y bellos: se vuelve ahora a concordar con ojos en lugar de con juicio.

${ }^{551}$ Es: según la disposición de là oración, seria esperable un verbo en plural, concordando con su sujeto (las mejillas...).

${ }^{552}$ En el manuscrito, San Juan, 5. Concretamente se trata de San Juan(5, 39-42)
} 
Y en estas Escrituras hay diversos libros, diversos preceptos y consejos que, todos con gran igualdad, sin contradicción ni discrepancia, dan testimonio del divino Esposo y son semejantes en su suavidad a las plantas aromáticas y al orden y composición de ellas en su consonancia y [ser] iguales. Y que la beca y labios de este santísimo Esposo sea ${ }^{553}$ hermosísima, dulcísima y muy suave ya lo mostramos arriba por las Sagradas Letras, y así lo testifica claramente el profeta, diciendo: Entre libros está derramada la gracia y suavidad ${ }^{54}$. Lo entendiendo por la dulzura de sus palabras y doctrina.

Las manos, después de esto, son la Escritura grande de este Esposo y sus obras tan perfectas y excelentes, a las cuales ningunas le[s] pueden igualar, así las de la creación, donde se muestran las grandes maravillas suyas, como las de la redención, donde se ve su gran misericordia.

Por el vientre entendemos el pecho y corazón del Esposo, según uso de la lengua hebraica. $Y$ dice que este es lucio, recio y blanco como el marfil, porque el corazón y afectos de amor que el Esposo tiene, fortísimos, simplísimos y blancos, son amando [a] los suyos sencilla y cándidamente y permaneciendo en este amor sin ningún doblez ${ }^{555} ; \mathrm{y}$ esto significan las piedras rojas con el marfil blanco del pecho.

Las piernas, que compara a las columnas fuertes, bien fundadas sobre basas de oro, es ${ }^{556}$ la fortaleza del Esposo, el cual es fundamento sobre que se asienta toda la religión, y fundamento fortísimo y firmísimo, que no puede ser desbaratado y gastado. Y quien quiera, que sobre él edificare y en él se afirmare con fuerte confianza, no caerá ni se desbaratará aunque el mundo se hunda, porque él sustenta todas sus cosas en la palabra de su fortaleza y virtud.

Y, por concluir, toda la vista de este divino Esposo es hermosísima y admirable, que no se puede acabar de comprender ni decir, porque es como el Líbano, donde hay tanta variedad de lindezas y suavidades. $Y$ es $\tan$ grande su excelencia y tan inseparable y eterna que, no sabiendo la Esposa a quién apodarlo, lo compara a los cedros, árboles altísimos y incorruptibles, y concluye que su paladar, sus hablas y sus doctrinas son dulcísimas, y todo cuanto en él hay es de desear, como quiera que sea sumo bien y en suma perfección. Tal confiesa la espiritual Esposa que es su amado Esposo, tal su bondad, tal su poder y fortaleza, por lo cual le preguntan las hijas de Jerusalén que dónde se ha ido. $Y$ esta ida del Esposo entendernos que es no sentir el alma la presencia, regalos y consolaciones divinas; $y$, para remeáio de esto, es menester que cuanto es en $\mathrm{si}^{\text {i57 }}$ todo[s] los fieles y principales hijos de la

\footnotetext{
${ }^{553}$ Sea: en singular, concuerda con boca, esta vez no el más cercano de sus sujetos. No añadimos el morfema de plural por aparecer el: femenino singular los adjetivos que le siguen, concordando igualmente sólo con el primero de los sujetos.

${ }^{554}$ En el manuscrito, salmo 46 (47). El titulo de este salmo es Canto al Dios victorioso.

${ }^{555}$ Ningún doblez: aunque ya dijimos al principio que no creiamos necesario ir señalando los numerosos casos de sustantivos con género diferente al actual, hacemos una excepción, por parecernos relevante este caso. Se puede plantear aqui una confusión al lector moderno, pues doblez, en castellano actual, posee diferente acepción según el género en que se emplee. En este ejemplo de nuestro texto aparece en niasculino, pero corresponde a la actual acepción del femenino.

${ }^{556}$ Es: al encontrarse lejos del sujeto, concuerda, en singular, con el atributo.

${ }^{557}$ Cuanto es en si: el contexto pide formas plurales.
} 
religión anden a buscar este Esposo [al que] está [la] Esposa rogando y suplicando continuamente que no aparte su espíritu de sobre ellos. 


\section{CAPÍTULO [VI ${ }^{588}$}

El mi amado descendió al huerto suyo, a las hojas de los aromates, [a] apacentar en los huertos y coger las flores. Yo soy del mi amado y mi amado es mio, el que pasta entre las fiores. Hermosa eres, amiga mía, como Tirsa ${ }^{559}$, bella como Jerusalén, terrible como los escuadrones. Vuelve los ojos tuyos, que me hacen fuerza. Ei tu cabello como las manadas de cabras, que están preñadas con Galad. Tus dientes como atajo de ovejas que suben del lavadero, las cuales todas paren de dos en dos. Tus sienes son como cascos de granada entre tu cabello. Sesenta son las reinas, ochenta las concubinas, y doncellas sin cuento. Una es la mi paloma, la mi perfecta, una es a su madre, ella única escogida es a la que [la] ${ }^{560}$ parió. Viéronla las hijas y llamáronla bienaventurada, y las reinas y las concubinas la loaron. ¿Quién es esía que de arriba mira como el alba, hermosa como la luna, escogida como el sol, terrible como los escuadrones? Al huerto de las nueces descendi para ver los frutos de los valles y ver si florecía la vid y si florecian los granados. No sé, mi ánima me puso con los carros de timinadab. Torna, torna, sulamita. Torna, torna y verte hemos.

\section{[EXPOSICIÓN]}

El mi amado descendió al huerto suyo, a las hojas de los aromates.

El Esposo, como aquel que con gran fervor ama, no está mucho ausente ni compadece ${ }^{561}$ que su Esposa se desespere buscando sin hallarlo. Él de su gana viene y le da a entender su venida. Como aquí vemos que anda la Esposa con grande ansia preguntando por su amado y luego que se aparejan todas para irlo a buscar, ella dice: "Ya es venido mi Esposo. Yo lo he sentido descender a su huerto". Y este huerto era el mismo donde la Esposa lo había antes convidado. Y dice que descendió, porque ella lo buscaba en Jerusaién, que era ciudad puesta en altura de un monte; y en los arrabales o aldeas, que están a la falda, se sigue la morada de esta Esposa rústica, donde estaba el huerto suyo y otros de sus vecinos, como es uso. Y dice que anda entre las eras de las plantas olorosas y que es venido a holgarse y regocijarse entre los lirios y violetas. Y dice la letra a pacer o apacentar porque anda cogiendo las flores o lirios, como cordero o cabrito que las paciese.

Y regocijada de esto mucho dice: Yo soy de mi amado y mi amado es mío. Quiere decir: "En fin, bien conozco cuánto me ama y cuánto favorece su amor al mío. Que, así como yo le buscaba, así me vino él a buscar a mí; y, como no podía estar sin él, viene corriendo a estar

\footnotetext{
${ }^{558}$ [VI]: realizamos esta la adición y suprimimos lo que hemios encontrado en el manuscrito ( $6^{\circ}-$ ) en un intento de homogeneizar los titulos de los capitulos

${ }^{559}$ Tirsa: en el manuscrito aparece la forma Thyrsa.

${ }^{560}$ [La]: reponemos a partir de la cita del parágrafo correspondiente.

${ }^{561}$ Compadece: padece.
} 
conmigo, y conozco que no se engañan los corazones y conozco que, así como yo soy suya, él es mío y no ama a otra sino a mí". Y estas son palabras entonadas con gran alegría y regocijo. Señaló diciendo: "Aquel, aquel amado mío, aquel que coge las flores y se huelga con ellas".

Aunque algunas veces nos parezca que Dios, airado por nuestras culpas y por no haberle querido abrir cuando llama, se haya alejado, no debe por esto la Esposa que bien lo ama desesperar, sino, acusando su yerro y descuido, buscarlo con gran diligencia, teniendo esperanza de hallarlo, y no solamente hallarlo, sino que él, de su voluntad, alegrisimo acudirá a la Esposa; porque él es muy fino enamorado y no desea sino que, si su amada le hace algún sinsabor, se conozca ${ }^{562}$ y torne a él; y por eso se ausenta y usa de otras artes para incitar.

Está el espiritual Esposo [dispuesto] a que le ame con gran fervor. Y, por esto, divinamente lo llama el profeta Joel "ancho de narices", dando a entender que todos los humos y enojos se le pasan luego, y no dura el deseo de castigo y venganza ${ }^{563}$. Y de este propósito hay muchos lugares en las Sagradas Letras. Y aquí lo muestra la Esposa diciendo que ya su Esposo es venido a su huerto y anda cogiendo las flores y rosas. Este huerto es el pecho de la misma Esposa, como arriba notamos, el cual está plantado de las suavísimas y olorosas palabras de la Divina Escritura, y con fe y con caridad adornado. Allí viene prestísimo el Esposo y coge de aquellas flores y lirios, y se huelga y regocija con tales manojos, como el cabrito cuando las pace; y entonces conoce la Esposa el ferviente amor de su Esposo, viéndolo tan olvidado de la ofensas pasadas, y canta con gran alegría: Yo de mi amado y mi amado mío. Y él, entonces, torna a loar a su Esposa como gran amor, como veremos.

Hermosa eres, amiga mía, como Tirsa [etc.].

Ensalza grandemente los grandes amores de su Esposa. Porque, en los capítulos de arriba, para loar la variedad de su gentileza y hermosura, la apodó a un gentil huerto; ahora la hace semejante a dos ciudades, las más hermosas que había en toda aquella tierra. La una se ilama Tirsa, que era ciudad de Palestina asentada en un monte, en la cual estaba la corte de los reyes de Israel antes que se poblara Samaria, adonde después se mudó. Y la otra es Jerusalén, que era la principal ciudad y la más hermosa que había en toda Palestina y aun en todo oriente, según tenemos noticia por las escrituras hebreas y gentiles. Y David hizo un salmo loando a la letra la grandeza, beldad y fortaleza de Jerusalén.

Pues de estas dos dice el Esposo que es semejante ${ }^{564}$ su Esposa en hermosura, diciendo: "Tan grande maravilla es verte cuán ${ }^{565}$ bella eres en todo y por todo cuan grande lo es ver estas dos ciudades reales, en la cuales las fortalezas de sus sitios, la magnificencia de sus edificios y la grandeza y hermosura de sus riquezas, la variedad de sus artes y oficios ponen grande admiración a quien las ve".

\footnotetext{
${ }^{562}$ Conocer (prnl.j: juzgar justamente de si propio (DRAE, 9).

${ }^{563}$ Alusión biblica sin anotación al margen en el manuscrito. Joel $(2,12-17)$. Hemos de ser̃alar que en todo el libro de Joel no se encuentra la expresion "ancho de narices".

${ }^{564}$ De estas dos... es semejante: modernamente, a estas dos.

${ }^{565} \mathrm{Cuán}$ : inicia una proposición subordinada completiva que realiza la función de complemento predicativo de $t e$, que es complemento directo de ver.
} 
Y tras esto, loándola, dice: Terrible como las banderas. Quiere decir "como las huestes que traen banderas"; y este es un subido ${ }^{566}$ punto de su loor, porque, como es manifiesto a todos los que buen conocimiento tienen de la verdadera belleza, no se puede con razón llamar tal la que no está guarnecida del friso de la granada moderada. Y, así, vemos que son condenadas muchas personas hermosas que no tienen vergüenza, mesura, gravedad y severidad, por fea[s] y aborrecibles; y de esto ser así podíamos traer muchos testimonios de la Escrituras $[\ldots]^{567}$ sino que el común y ordinario juicio no demanda probanza en tal caso. Así que la hermosura acompañada con una honesta severidad es más acatada y reverenciada y amada de los virtuosos; a la desvergüenza no tiene ${ }^{568}$ entrada ni atrevimiento para recuestarla ${ }^{569}$. Por tanto, quien $10^{570}$ ama está muy cierto y asegurado de la fieldad ${ }^{571}$, teniendo por prenda la virtud, [de] donde procede aquella autorizada esquineza.

Esta parte muestra el Esposo haber en su Esposa, diciendo: "No solamente eres hermosa, mas $^{572}$ tienes tanta gravedad y majestad que no pareces sino una compañía de gente de guerra que viene en gran concierto, obedeciendo y siguiendo a su capitán, y sin alborotos entre sí, tal que pone gran temor al que la ve y no hay quien ose cometerla ${ }^{573}$. No es menos la gravedad y majestad de tu hermosura, que todas sus partes están tan asentadas y ordenadas, sin hacer un mínimo movimiento fuera de lo que el decoro y honestidad ordena[n], que no hay quien se atreva con desvergonzados ojos [a] acometértele".

Digno es de consideración ver que el Esposo, después de venido, loa con más artificio a su Esposa y se levanta más en las semejanzas, dando a entender el gran amor que la tiene, sin acordarse del enojo pasado. Esta letra así entendida ${ }^{574}$, está claro el espíritu: que el Esposo celestial, cuando torna a su Esposa, entendiendo la enmienda y grande amor de ella, la alaba mucho más y le muestra más amor; $y$, en alabarla por la semejanza de las dos ciudades que ha nombrado, da a entender que en ella está el ornamento de todas las virtudes y hacen una bella compañía y graciosa unión, como una ciudad, y con mayor fortaleza y mayor resistencia de sus contrarios y de quien la procura dañar. Y esto acrecienta a lo que arriba había dicho llamándola "huerto cerrado a quien ninguna bestia puede hacer perjuicio", como si dijese: "No solamente

\footnotetext{
${ }^{566}$ Subido: ver nota 24.

${ }^{567}[\ldots]$ : Salto sintáctico. Probablemente el texto esté mutilado.

${ }^{568}$ Tiene: no está claro si el sujeto de este verbo es el mismo de la oración anterior o si se trata de una construcción de indeteiminación de agente. En el primer caso, habria un fallo de concordancia, debiendo ir en plural; en el segundo, se trataria de una construcción de las que hoy se realizan con se.

${ }^{569}$ Recuestar: pedir.

${ }^{570} \mathrm{Lo}$ : debido a la oscuridad de este pasaje -por la posible mutilación a la que hemos hecho referencia-, no queda claro a quién o qué pueda referirse este pronombre.

571 Fieldad: fidelidad. Forma antigua.

572 Mas: equivalente a sino.

${ }^{573}$ Cometer: acometer. Uso antiguo.

${ }^{574}$ Esta... entendida: construcción de participio absoluto
} 
huerto cerrado, que es poco, mas $^{575}$ ciudad fuerte y hermosa te llamo". Y luego loa la majestad y gravedad de su divina Esposa espiritual, dando a entender que es tan severa que ningún enemigo desvergonzadamente la osa acometer, cual es ${ }^{576}$ el demonio, las falsas religiones, las herejias y desconciertos, que están con deseo de desbaratar la honestidad de esta santa Esposa y de triunfar de ella ${ }^{577}$ y gozar de su belleza; mas $^{578}$ las sabe muy bien despedir y arredrar de sí con la grave muestra de su vista. Lo mismo hace cualquier particular amador del divino Esposo, que procura conservar la hermosura de su ánima con la constancia en el bien y con rebasar los contrarios cometimientos ${ }^{579}$.

El Esposo, querierdo contar otra vez la belleza de su Esposa, habiéndola loado primero en universal, queriendo mostrar una por una sus partes, como luego se verá, lo primero que miró para loarla fueron los ojos, de los cuales antes había hablado subidamente ${ }^{580}$ y muy largo. Ahora, queriendo empinar ${ }^{581}$ más aquelia loa, usa de una elegantísima manera, no diciendo la hermosura de sus ojos sino rogando que los aparte y vuelva a otro cabo mirando, como si dijese: "Deseo, Esposa mía, contar otra vez de tus ojos; mas ellos son tan bellos y graciosos y tan resplandecientes, y tienes en ellos tanta fuerza que, al tiempo que los miro para alabarlos, contemplándolos, queriendo coger una a una y contemplar sus gracias, ellos me arrebatan y me roban y con su luz me encandilan, de tal manera que, por la fuerza que el amor me hace, estoy como elevado; por tanto, Esposa dulcísima, vuélvelos, no me mires, que no puedo resistirlos". Y, demandando esto el Esposo, demanda lo que no quiere, que es que su Esposa no le mire, porque es gran placer el que siente con esta vista; mas, con tal demanda, dice más en su loor que si dijera muy por extenso todas las partes de su belleza que en ellos se encierra. Y estas son [las] cosas que mejor se entienden, que se pueden declarar.

Habiendo tan altamente loado los ojos por este sutil artificio, enhila tras esto las otras partes del rostro -dientes, labios y mejillas- diciendo las mismas palabras que arriba dijo, porque aquellas semejanzas son tan excelentes que no se pueden aventajar.

Tu cabello manada de cabras que están preñadas en Galad. Tus dientes como atajo de ovejas que suben del lavadero; todas ellas paren de dos en dos y ninguna entre ellas deshilada. Tus mejillas como un casco de granada entre tu cabello.

Esto dice por la blancura y igualdad de los dientes y por el color gracia y buen asiento de las mejillas, como en el capítulo cuarto vimos, donde se declaró esto muy a la larga.

En el espiritu, entendemos que, cuando los ojos de la Esposa, que son el juicio y entendimiento con que ve y juzga, en los cuales está[n] la fe y buen conocimiento de Dios, de

\footnotetext{
${ }^{575}$ Mas: equivalente a sino.

${ }^{576}$ Es: en singular, concuerda únicamente con el más cercano de sus sujetos.

${ }^{577}$ Triunfar de ella: lo habitual actualmente seria sobre ella.

${ }^{578}$ Mas: equivalente a sino.

${ }^{579}$ Cometimientos: acometimientos. Ver nota 573.

${ }^{580}$ Subidamente: ver nota 24

${ }^{581}$ Empinar: uso semejante a los que estamos observando en las diversas formas derivadas de subir
} 
donde procede el simple y fiel amor suyo, por lo cual arriba los llama ojos de paloma; cuando $^{82}$ estos ojos están tan hermosos como aquí los ha pintado, entonces los loa mucho y da voces en su loor, diciendo: "Tus ojos me roban el corazón, tus ojos me fuerzan en tu amor". De los cabellos de que cercan estos ojos ya dijimos que eran los hermosos y asentados pensamientos y la dulce, suave y simple reprensión de la santa Esposa, que por los dientes se entendía. Y la buena hermosura y caritativa razón de vida se llama aquí, como arriba, rostro o mejillas blancas, coloradas y sacadas de los buenos pensamientos que los cabellos dan a entender, y asi se perfecciona su hermosura del rostro de quien Dios se enamora tanto.

Sesenta son las reinas y ochenta las concubinas; innumerables doncellas. Una es la mi paloma, la mi perfecta, única es a su madre, ella escogida es a la que la parió.

Muestra el Esposo cuán excesivo sea el amor que a su Esposa tiene, diciendo en persona suya (como si declarase que es Salomón rey este pastor que aquí se representa): "Sesenta son las reinas que tengo por mujeres y ochenta las concubinas -entendiendo, por estos números, números muchos y muchos más, segín el uso hebreo- y las doncellas que están al servicio de estas mujeres y mío son tantas que no se pueden contar. Mas, así como esta mi paloma, que con tanta fe, lealtad y simplicidad me ama, es única en perfección y belleza, así es única para mí, únicamente amada, por lo cual están todas las mujeres maravilladas; $y$, viendo su extraña belleza y el grande amor que yo le tengo, la han loado y llamado dichosa y bienaventurada con gran regocijo, y le han robado mil bienes, como aquellas que sin envidia conocen la ventaja".

Podemos entender, por el número de las reinas o mujeres principales, las mayores Iglesias $(y)^{583}$ con quien[es] está casado el divino Esposo; y, por las concubinas, que son menores, $(y)^{584}$ las particulares Iglesias y congregaciones de ios fieles; y, por las doncellas, todas las particulares ánimas creyentes, que son much $0^{585}$ más. Y, como quiera que todas amen al divino Esposo no divisamente ${ }^{586}$ sino en una unión y confirmación santa, de tal manera que todo sea uno y una de religión, según aquello, un Cristo, un bautismo, un Dios y padre de todos ${ }^{587}$; por eso $^{588}$ dice aquí el Esposo: "Aunque son muchas más las mujeres mayores y menores, y las demás doncellas de mi servicio, una es la que amo, una es ía mi paloma, que con simplicidad guardó los mis preceptos, la que mucho me ama y la que en mí mucho cree; y esta es única para conmigo en amor, y una para su madre, y única para la que ia parió -que es lo mismo-".

La madre de esta Esposa es la predicación, que es una madre sola y tiene por hija la verdadera y santa religión. Y esta madre y su parto se declaran por aqueliaz palabras:

\footnotetext{
${ }^{582}$ Cuando: retoma la construcción comenzada tres lineas más arriba.

${ }^{583}(Y)$ : suprimimos la conjunción, que resulta clarameite inadecuada, dado que la proposición de relativo está subordinada a la anterior y no coordinada con ella.

${ }^{584}(Y)$ : suprimos la conjunción, que, a la luz de la construcción que antecede y la que sigue, es claramenie sobrante.

${ }^{585}$ Mucho: segun el sentido, seria esperable aqui la forma adjetival muchus en lugar de esta forma adverbial.

${ }^{586}$ Divisamente: adverbio formado sobre diviso, participio irregular de dividir, poco usado. Esta forma, procedente dei verbo latino divido (supino divisum) se utiliza más en compuestos, como indiviso.

${ }^{587}$ En el manuscrito, Carta a los Efesios, 4 . Concretamente se trata de Carta a los Efesios (4, 1-6)

${ }^{588}$ Por eso: retoma la construcción comenzada tres lineas más arriba $(Y$, como quiera que...).
} 
Predicador, por el Evangelio os pari ${ }^{89}$; y en otro lugar: Hijicos mios, los cuales traigo en mi vientre para parir otra vez ${ }^{590}$. Y este aparto ${ }^{591}$ y preñez en San Pablo se entienden especialmente cumo aquí, en este lugar de los Cantcres, la madre.

En la letra dice reinas, que quiere decir "mujeres legítimas", y dice concubinas. Las concubinas entre los hebreos no eran mancebas, como algunos lo entienden, sino mujeres legitimas, que habian sido esclavas o criadas y las toma su amo por mujeres, mas no se celebran las bodas por instrumento escrito ni con las ceremonias legítimas que en casamiento de las otras libres se usaban; y estas se cñadían a las mujeres principales. Los hijos que de estas [nacian] no sucedian en los mayorazgos ni herencias capitales, mas podia bien el padre dotarlos de grandes dones para sustentamiento de sus vidas, como de todo esto hay claro testimonio, en el Génesis, de Cetira y Agar, mujeres de Abraham. Y, así, la Escritura Sagrada más veces llama nombres de mujeres legítimas y otras concubinas ${ }^{592}$. sol?

¿Quién es esta que de arriba mira como el alba, hermosa como la luna, escogida como el

Estas son palabras de aquellas mujeres que veían la hermosura de aquella Esposa y la loaban, diciendo: "¿Quién es aquella que viene allí mirando hacia nosotros ${ }^{593}$, que no parece sino el alba cuando asoma, tocade y muy hermosa, y es tan bella entre las mujeres como la luna entre las menores estrellas; antes, por mejor decir, es resplandeciente y entre todas escogida, como el sol entre todas las lumbreras del cielo?" Que, así como el sol es principio entre todas las luces soberanas y escogida ${ }^{594}$ en tal manera que todos participan y se aprovechan de su nombre, así esta es dechado de toda beldad; y la que a ella más se pareciere más hermosa será; juntamente con su hermosura, tiene buena gravedad y majestad, que no parece sino un escuadrón, que [a] todos pone reverencia y temor. Y, en decir escogida como el sol alude a la grande belleza de ella y a la grande estima, en que su Esposa se tiene ${ }^{595}$ más que a las otras. Y es muy gentil manera esta de hablar y de loar. Dice piimero alba, que es hermosa y resplandeciente; y luego luna, que es más; y después sol, que es sumo en este género. Y los artífices de hablar loan mucho en este modo de decir y le llaman encarecimiento acrecentado.

El sentido alegórico de esto está claro: que las fieles ánimas, movidas de admiración, alaban la gran beileza de esta Esposa, confesando y manifestando la gran ventaja de ella sobre todas las religiones y sectas del mundo, porque su fe, sus buenas obras y sus virtudes todas exceden a las otras, como el alba a la noche y tinieblas y como la luna y el sol a todas las otras estrellas.

\footnotetext{
${ }^{589}$ En el manuscrito, Carta a Timoteo, 4 . Concretamente se trata de II Carta a Timoteo (4, 1-5).

${ }^{590}$ En el manuscrito, Carta a los Gálatas, 4. Concretamente se trata de Carta a los Gálatas (4, 13-19).

591 Aparto parto.

${ }^{592}$ En el manu'scrito, Génesis, 25 y 35 . Concretamente, se trata de Génesis $(25,6$ y 35,22$)$.

${ }^{593}$ Nosotros: en masculino, error de concordancia. pues son aquellas mujeres las que están hablando.

${ }^{594}$ Escogida: este adietivo va referido a sol, por lo que deberia ir en masculino. Suponemos que se sobreeentiende luz escogida, y por ella aparece el adjetivo en femenino.

${ }^{595}$ Se tiene: construcción oscura. En principio, parece légico que no se trate de un se reflexivo sino de una pasiva refleja. Sin embargo, esta interpretación no encaja del todo si tenemos en cuesta la preposición a que aparece después. A la luz del pasaje paralelo del Comentario según la letra, en ei que nodemos leer en que su Esposo la tiene, podriamos pensar que se trata de un error.
} 
$\mathrm{Y}$, así, es manifiesto que todo lo bueno que todas las otras religiones tierien, como son algunas sentencias y doctrinas para regirse y gobernarse los hombres en la vida y las obras, $y$ todo lo demás, son pequeñisimas y muy oscura cosa, en $\operatorname{pos}^{596}$ de la abundancia y claridad que en todo tiene la Esposa Iglesia Católica, teniendo la verdadera religión consigo y siendo enseñada del padre de los hombres.

Al huterto de los nogales descendi a ver los frutos de los valles y si florecía la vid y si florecen los granados ${ }^{597}$. No supe, mi ánima me puso con los carros de los príncipes de mi pueblo.

En las palabras de arriba, andando la Esposa a buscar a su Esposo, lo sintió que ${ }^{598}$ andaba en el huerto y que era venido a verla y regocijarse con ella, y la tornaba a loar enamoradamente. Ahora, la Esposa cuenta lo que después de esto le sucedió, diciendo: "Como yo sentí que mi Esposo estaba en el huerto, en el cual hay nogales, parras, granados y otras plantas, luego en este punto descendí aguijando allá y fui tan presta en llegar que no se cómo me fui ni cómo no, más ${ }^{599}$ de como ${ }^{600} \mathrm{mi}$ ánima me aguijó tanto y me puso tanta fuerza y ligereza para correr que no me pareció sino que había ido en un muy ligerísimo carro de los que usan los principales y poderosos de mi pueblo".

Y, contando esto, dice lo que le sucedió con las mujeres que, viéndola con tanta presteza, le decían: "Torna, torna acá, sulamita, torna, no te des tanta priesa, porque ${ }^{601}$ te veamos, que no hemos aún considerado ni gozado de toda tu beldad". La letra está ahora clara, que parecía un poco revuelta, porque es traducida de lengua extraña y son palabras de enamorada y, otras veces, les sobran las razones a los tales apasionados, como hemos dicho. Aquí consideramos la gran fuerza que tiene el amor $\mathrm{a}^{602}$ los que se rigen debajo de sus fueros y qué milagros suelen mostrar ellos, pues dice la Esposa que, sintiendo desde la ciudad a su Esposo, que andaba abajo en el huerto, fue tan presta en el descender que le pareció que iba en carros ligerísimos, y aunque no tuvo respeto a los que con ella estaba[n], sino ${ }^{603}$ al mejor hablar los dejó con la palabra en la boca -como dicen-. Y de estas vemos muchas experiencias cada hora en personas que aman; o, por respeto de la persona amada, se ponen a cojas, que parecen contra natura 0 fuera de todo humano puder, y salen con ellas tales que ellos mismos se espantan y no saben cómo hicieron aquello. $\mathrm{Y}$, entre otras muchas que en nuestro tiempo hemos visto y oído, una

${ }^{596}$ En pos de: en comparación con

${ }^{597}$ Los frutos... granados: se coordina un C.D. formado por un sintagman nominal con otros dos, formadns esta vez por preposiciones.

598 Lo sintió que: no está clara esta construcción. Podria considerarse que el verbo está construido con doble C.D., por un lado lo y por otro la completiva que comienza con que. Otro posibilidad seria considerar ese que como un relativo, que iria referido a Esposo. En esta segunda interpretación deberia aparecer una coma después del verbo. Al no ponerla, nos inclinamos por la primera interpretación.

${ }^{599}$ Más: además.

${ }^{600}$ Como: parece darse comienzo aqui a una proposición causal antepuesta a al principal, en una estructura paralela a la de la oración anterior. Sin embargo, esta principa. no aparece, quedando la oración sin terminar al producirse un anacoluto. Este problema puede solucionarse entendiendo en este lugar que en lugar de como.

${ }^{601}$ Porque: valor final

${ }^{662} \mathrm{~A}$ : lo usual, actualmente, seria para.

${ }^{603}$ Aunque... sino: se trata de una secuencia que puede despistar al lector actual. Esto se debe a que la proposicićn que aparece encabezada con aunque no es en realidad subordinada de nadie, sino que es la principal, a la que luego se enlaza la adversativa que viene introducida po: sino. 
es esta: que un hombre de gran verdad me juró haber andado en hora y media a pie más de seis leguas de asperísimo camino por ver a su mujer, de la cual le dijeron estar en el último paso y que tenía gran agonía por verlo antes de su muerte, y él dejó una cabalgadura -en que venía por ciertas medicinas- en poder de uno que lo venía a buscar; $y$, en una hora de sol y media hasta las avemarías, llegó a su casa y vio a su mujer viva, y en este punto murió, despidiéndose de él. De esto me señaló dos testigos que le vieron partir y toda la vecindad que estaba en su casa cuando llegó, y me lo contaba con gran admiración. Yo me maravillé, y más porque era hombre grueso, y me pareció que apenas podría, con tal disposición, andar en seis horas media legua.

La ocasión de la Esposa nos ha hecho salir de la letra, aunque no del propósito. Ahora, tornando a él, notaremos que, entre los árboles que aquí cuenta la Esposa, el nogal es el primero, y le da la nombradía del huerto, diciendo al huerto de los nogales. En nuestra provincia, los nogales más se ponen en los valles y otras heredades anchurosas de granjería que no en huertos de pasatiempo y recreación, porque hay muchos y, con su sombra, ocupan mucho campo y aun son dañosos a los otros árboles, según lo que se lee y experimenta de ellos. En Tierra Santa hay pocos, y criados con regalos, y, por eso, los tienen en grande estima $y$ adornan sus huertos de ellos como cosa rara. $Y$ aun somos enformados ${ }^{604}$ [de] que en ningún tiempo no hay más de uno en toda la comarca de Jerusalén, y este [se] tiene en gran precio, y muy cercado y guardado. Por esto, la Esposa hace tanto caso de él y dice que iba a ver si las vides y granados florecían; mas no se entiende que iba sola $[y]$ principalmente a esto, por lo de arriba que dijo que vio a su Esposo allá, y por lo que después dijo declarándose que su ánima la había llevado con tanta presteza. Mas, yendo al huerto por ver a su Esposo, vio cómo ç caban las plantas de él y cuales florecían y cuáles tenian fruto; y esto se siguió del ir allá, mas no que fuese causa de la ida. Y es esto como si dijera: "Fui corriendo a ver mi huerto si florecía". Porque no era posible sino que, estando en él, todo había de renovarse y brotar de bellas flores. Y que esto sea así se muestra por lo del Esposo arriba, que, viniendo al huerto de su Esposa por verla, decía que cogió de las flores. Y ella, convidándole a que la viniese a ver al huerto, decía: Venga mi amado y coma de los frutos que están para él guardados.

[En] cuanto a las sentencia de estas palabras, entendemos que la Esposa, entendiendo la vuelta de su Esposo, cuyos espirituales gustos, sentimientos y regalos antes no probaba por su culpa, prestísimo torna [a] su deseado Esposo; y, en este tornar, es tan ligera cuanto la mueve la alegría de su ánima y favor de su Esposo, que le pone alientos y fuerza para ellos. Y, así, con tan grandísima voluntad, lo recibe, viendo su gran misericordia, que tiene por bien (de) ${ }^{605}$ tornar a ella, no acordándose de los enojos pasados, antes loándola más y mostráa: dole mayor amor. Y a este su Esposo lo halló en el huerto de las nueces, que es en las Divinas Escrituras, cuyos sentidos y entendimientos son como el fruto del nogal, que debajo de aquella corteza o cáscara tiene el dulcísimo meollo, que es muy preciado de los moradores de la Tierra Santa, que son los hijos de las divinas promisiones, los que creen y siguen la religión cristiana. $\mathrm{Y}$ en este huerto la Esposa mira si florecen las vides y los granados y los otros árboles. Quiere decir que estudia y procura entender los preceptos de los Santos Libros para que de este entendimiento venga a creer y obrar lo que allí se manda y coja el fruto de las promisiones y

\footnotetext{
${ }^{604}$ Enfirmar: informar.

${ }^{605}$ (De): tuuevo caso de infinitivo en función de C.D. construido con la preposición de.
} 
bendiciones que alli están hechas. Y esto parece que significa el mirar si florecen las plantas, para que de aquesta flor se espere el fruto. Así que en aqueste huerto se halla el Esposo, con cuya presencia y favor luego las flores del buen entendimiento se muestran.

Donde declaramos y trasladamos carros de los principes de mi pueblo, seguimos el vocablo hebreo, que es a aminadib ${ }^{606}$, que el intérprete latino lo dijo así, sin interpretar sino en su voz hebrea. $Y$ algunos se engañarían pensando que era nombre propio del algún lugar. mas son nombres que quieren decir "de mi pueblo príncipe". Y esto dice porque, como en tierra de Judea había pocos caballos, toda la más gente usaba ir cabalgando en asnos, si no $\operatorname{eran}^{607}$ los poderosos y principales de ella, que hacian traer de Egipto caballos muy buenos y ligeros, y andaban en carros que traen aquellos caballos.

El vocablo sulamita, como está en la letra criginal, quiere decir "hierosolamita" o "mujer de Jerusalén", como llamamos "romana" a la mujer de Roma. Y esto es porque Jerusalén se llamaba ntiguamente Salem, como lo hallamos en la Escritura Sagrada, adonde ${ }^{608}$ dice: Melquisedec, rey de Salem ${ }^{609}$. Y David, encareciendo la misericordia que Dios había hecho a los hebreos en tomarlos por suyos, entre otras cosas dice: $Y$ entre ellos mora y su lugar está en Salem $^{610}$. Adonde ${ }^{611}$ el latino traslada en paz después se llamó Jerusalén.

\footnotetext{
${ }^{606}$ Aminadib: más arriba hemos encontrado al iorma timinadab.

${ }^{607}$ Si no eran: a no ser.

${ }^{608}$ Adonde: donde.

${ }^{609}$ En el manuscrito, Génesis, 14. Concretamente se trata de Génesis $(14,18)$.

${ }^{610}$ En el manuscrito, salmo 76 (75). El titulo de este salmo es Canto de victoria.

${ }^{611}$ Adonde: donde.
} 


\section{[CAPÍTULO VII]}

¿Qué miráis en la sulamita como órdenes de los ejércitos? ¡Cuánto son bellos tus pasos en el calzado, oh, hija del príncipe! Los cercos de tus muslos como collares obra de mano de maestro. Tu ombligo como taza de luna que no le falta bebida. Tu vientre un montón de trigo cercado de violetas. Los dos pechos tuyos como dos cabritos mellizos de una cabra. Tu cabello $^{613}$ como torre de marfil. Tus ojos fuente de Hesebón ${ }^{614}$ junto a la puerta de BatRabim $^{615}$. Tu nariz como la torre del Libano, que mira frontero de Damasco. La cabeza tziya como el Carmelo. ¡Cuán bella eres y cuán dulce eres, amada, en los deleites! Esta tu estatura semejante a la palma, y tus pechos a los racimos. Dije: Yo subiré a la palma, asiré sus racimos y serán tus pechos como los racimos de la viá, y el olor de tu nariz como de las manzanas, y tu paladar como excelente vino, que va a mi amado a las derechas, que hace rebosar los labios de los viejos. Yo soy de mi amado. Salgamos al campo, pasemos las noches en las granjas, levantémo[no] $s^{616}$ de mañana a las viñas y veamos si florece la vid, si se ha mostrado el agraz, si brotaron los granados. Ahi te daré mis amores. Las mandrágoras trascienden y en nuestras puertas todos los frutos, asi viejos como nuevos, los guardé para ti.

\section{[EXPOSICIÓN]}

¿Qué miráis en la sulamita como órdenes en los ejércitos?

En el fin del capítulo pasado, vimos cómo las mujeres se ponían con gran atención a ver [a] la Esposa y le rogaban que no se diese tanta priesa, sino que tornase y se parase un poco para que la viesen, que no se hartaban de mirarla. En el principio de este, se introduce un tercero que pregunta a estas mujeres que miran qué cosa hay que ver tanto en aquella hierosolimitana doncella que con tanta atención están todas a mirarla, puestas en orden y en calle como suelen ponerse los escuadrones, y les pregunta con grande admiración. [Siguen] diciendo:

¡Cuánto son bellos tus pasos con el calzado, oh, hija del príncipe!

Comienzan la loa de esta belleza las mujeres desde los pies hasta la cabeza, por ir desde lo menor hacia lo mayor, que es galana manera de loar. Dicen pues: „¡Oh, princesa! ¡Cuán hermosos son tus pasos, cuán gentiles son tus pies y con qué gracia los mueves! Y el calzado que en ellos tienes está tan bien que parece nacido alli". De manera que, diciéndole del calzado, la loan de la hermosura y gracia de los pies, y de la gracia en el andar, que es parte

\footnotetext{
${ }^{612}$ [CAPITULO VII]: realizamos esta la adición y suprimimos lo que hemos encontrado en el manuscrito (Cap. $7^{\circ}$.) en un intento de homogeneizar los titulos de los capitulos.

${ }^{613}$ Cabello: según lo que encontramos más adelante, en la Exposición de este pasaje, parece claro que se trata de un error: cabello en lugar de cuello.

${ }^{614}$ Hesebón: en el manuscrito encontramos la forma Hesbon.

${ }^{615}$ Bat-Rubim: en el manuscrito encontramos la forma Batrabin.

${ }^{616}$ Levantémo/no]s: completamos la forma según la que aparece en el parágrafo correspondiente, considerando que se adecúa mejor al sentido.
} 
grande de la belleza, como ya hemos dicho, que en los movimientos está gran parte de ella. Luego la alaban de los muslos y piernas, diciendo: "Los cercos de tus piernas -o muslos- son como ajorca ${ }^{617}$-o collar muy bien labrado de mano de maestro-". Y esto dice[n] por la espesura de las piernas, que no son flojas, sino recias y bien hechas, redondas; en tal manera que, si hiciese un buen artífice un collar -o ajorca- muy perfecte en redondez y se lo ciñese a las piernas, vernía ${ }^{618}$ justo y se hincharía todo el redondo de la carne de ellas. Y esto es parte de beldad, ser las piernas bien hechas, no sólo en las mujeres $\operatorname{mas}^{619}$ también en los hombres.

\section{Tu ombligo como taza de luna que no le falta bebida.}

Quiere decir: "Sobre estas dos hermosas y recias columnas de tus piernas se asienta el bello edificio de tu persona; la primera parte es el ombligo y vientre tuyo ${ }^{620}$, el cual está muy hermosamente proporcionado, porque no parece sino una taza tan redonda como la luna y que ${ }^{621}$ esta taza siempre está llena de mixtura, que es vino mezclado con agua para beber; así, ni más ni menos, es el vientre: [lleno] ${ }^{622}$ de virtud que nunca le falta". Y, para más declarar esta loa del vientre, torna a decir: "Es tu vientre tan redondo y lleno, tan hermoso en su blancura, como un monte de trigo cubierto de violetas blancas y lirios". Y' es muy gentil apodo este, porque el montón de trigo está por todas partes igual en redondez, que en ninguna parte de él hay seno o hoyo alguno, porque luego los granos lo hinchen; y así dice ser, de toda parte lleno y levantado, el vientre de la bella Esposa, [a] la cual aquí llaman princesa las mujeres, porque la Esposa de Salomón, que es la figura y sombra que en esta canción se loa, era hija de un rey de Egipto; y también se lo dicen por vía de regalo y encarecimiento, como acá solemos decir: "Tiene una presencia y una tan gentil vista que parece hijo de un rey".

Después le loan los pechos, viniendo por su orden en la fábrica del cuerpo, y dicen que ambos -los pechos de la Esposa- están tan gentiles, tan llenos y agraciados que parecen dos cabritos parejos, mellizos, hijos de una cabra. Y el cuello, que está sobre los pechos, es largo, derecho, parejo y blanco, que en su beldad parece una torre hecha de blanco, liso y reluciente marfil. "Los tus ojos -después de esto- son grandes, claros, llenos y bellísimos, como son las fuentes que están en Hesebón", que es una ciudad fresca de Israel, la cual ganaron los hebreos a Sión, rey de los amorreos. Y estas fuentes que aquí dice la letra están junto a la puerta de la ciudad que se llama Bat-Rabim, que quiere decir "hija de muchedumbre", y es nombre de una puerta por la cual entiendo daban luego a una plaza grande, y capaz de mucha gente. Y, según uso hebreo de hablar, se llama "hija de muchos" aquella plaza porque los hebreos se sirven de

\footnotetext{
${ }^{617}$ Ajorca: Especie de argolla de oro, plata u otro metal, que para adorno traian las mujeres en las muñecas, en los brazos o en la garganta de los pies (DRAE)

${ }^{618}$ Vernia: forma de condicional arcaico.

${ }^{619}$ Más: equivalente a sino.

${ }^{620}$ Tuyo: concuerda en singular con el sustantivo más cercano, es decir, con vientre, aunque se refiera también a ombligo.

${ }^{621}$ No parece sino una taza... y que: Si no apareciera esa conjunción $y$, podria pensarse que la forma que fuera un relativo, dependiendo de taza (significando la cual taza...). Pero, tal y como encontramos el texto, se trata de una doble construcción con parece. Dos complementos predicativos: taza y la completiva encabezada por que.

622 [Lleno]: realizamos esta adición, que consideramos importante para el sentido, a partir del Comentario según la letra. Dado que este fragmento es casi literal en ambo\& textos y que en esta oración existen aigunas diferencias, la transcribimos según el otro textos, pues pensamos que en esie se han producido mutilaciones: "Asi, ni más ni menos, es el tu vientre: redondo, bien hecho, ni flojo ni flaco, sino lleno de virtud, que nunca le falta."
} 
nombre de "hijo" en muchas cosas; como, por decir "mi sabio" dicen "mi hijo de sabiduría"623; por "muy malo", "hijo de maldad".

Dicen luego, loando lo demás: Tu nariz es semejante a la torre del Libano que mira hacia Damasco. La cual torre estaba puesta en aquel monte tan nombrado y celebrado por su frescura, y era muy fuerte, porque servía de atalaya en la frontera de Damasco, que era cabeza de Siria. Asi, [dice]: "Esta tu nariz hermosa y bien hecha, que se levanta fuera del bellísimo rostro [es] como aquella hermosa y fuerte torre [que] ${ }^{624}$ está asentada sobre el fresco monte Líbano y se levanta sobre él".

El sentido figurado de esta letra [lo] podemos declarar así: que los pies calzados de la divina Esposa den a entender la bella prontitud y diligencia que los predicadores de la palabra de Dios tienen, los cuales pasos le están muy bien a la Esposa y le agracian mucho, conforme [a] aquello de Isaías que en esta sentencia trae San Pablo: $;$ Cuán hermosos son los pies de los que llevan la buena nueva de la paz! $!^{625} \mathrm{Y}$ el mismo Apóstol a los Efesios ${ }^{626}$, exhortándolos a la publicación de este Evangelio, dice: Calzados los pies, aderezados para el Evangelio ${ }^{627}$.

Por los muslos y piernas recias y bien hechas entendemos la potencia y virtid para engendrar, $(y){ }^{628}$ la cual los hebreos dan a entender por los muslos, como se ve en el misterio del juramento que tomó Abraham a su siervo ${ }^{629}$. Pues quiere decir esta loa de los muslos que la virtud y fuerza de engendrar hijos espirituales que tiene la Esposa es grande y muy recia, perfecta del tojo y acabada como el círculo, que es figura perfectísima. Y esto luego se declara en lo de abajo, porque, de la misma manera entendemos la redondez del vientre, semejante a la taza redonda que jamás esta vacía, que por esto se denota la fertilidad de esta sagrada Esposa, que siempre está llena de nuevas preñeces espirituales, pariendo cada día hijos fieles; y nunca cesan estos santos partos, sino son espesos como granos de trigo que están en un montón o vientre. Está hermosísimo con la blancura y simplicidad de los santos -que aquí significan los lirios-, porque la santidad de estos es grande ayuda para la multiplicación del fruto en el vientre de la Esposa. Y, después que ha parido estos hijos, les da leche de los dos pechos, Testamento[s] Nuevo y Viejo, que son iguales de igualdad y autoridad, como quiera que son hechos y firmados de un mismo Dios, que no puede faltar ni se muda jamás.

\footnotetext{
${ }^{623}$ Mi sabio... sabiduria: por analogia con el ejemplo posterior (y también en base al Comentario según la letra), seria aqui esperable el adverbio muy donde el posesivo mi, en mi sabio, y estaria de sobra en mi hijo de sabiduria.

${ }^{624}$ [Es]... [que]: de nuevo las adiciones proceden del Comentario segin la letra. Los pasajes resultan exactos en todo lo demás. Por ello y no resultar del todo coherente la sintaxis de esta oración, hemos creido necesarias las adiciones.

${ }^{625}$ Alusión biblica sin anotación al margen en el manuscrito. Esta idea se recoge en Isaias $(52,7)$. La cita corresponde a Romanos (10, 15).

${ }^{626}$ Efesios: en el manuscrito, aparece abreviado: Efes.

${ }^{627}$ En el manuscrito, Carta a los Efesios, 6. Concretamente se trata de Efesios (6, 14-15),

${ }^{628}(Y)$ : se da el mismo fenómeno que hemos visto ya páginas atrás: la ccnjunción debe ser suprimida, dado que la proposición que la sigue no está coordinada con la anterior sino subordinada a ella.

${ }^{629}$ Esta idea se recege, como sef̃ala el manuscrito en anotación marginal, en Génesis, 24. Concretamente se trata de Génesis (24, 1-4).
} 
El cuello de la Esposa, como ya vimos, es la voluntad, en la cual en ella es derecha y sencilla y blanquísima, sin ninguna mancha de fealdad humana, y fuerte y constante, $y$ en todo esto se parece al marfil.

Los ojos de la Esposa, que son el juicio y entendimiento, son hermosos, claros y llenos como dos fuentes, porque, ejercitada en la ley de Dios, tiene claro y lleno el juicio, que no le faltará; antes, sobrepuja a toda la sabiduría del mundo, como dice David: La ley del Señor sin tacha, que enamora los corazones; el testimonio del señor fiel, que da sabiduría a los pequeños. Y en otro lugar: El precepto del señor resplandeciente, que alumbra y hace claros $\operatorname{los}_{\text {ojos }}{ }^{630}$.

La nariz -después de esto-, siendo el instrumento de oler, es señal también de la ira y reprensión, como vemos arriba, trayendo el dicho de $\mathrm{Job}^{631}$. Hacen, pues, semejante la nariz de la Esposa al Libano, que mira a Damasco, porque está muy avisada la Esposa, oliendo y conociendo la infidelidad y sus argumentos, lazos y traiciones, para guardarse de ellos y avisar a los suyos [de] que se guarden y, con la defensa de la reprensión, echar de sí todos los daños que le cometen, así como la torre estaba en el Líbano para centinela ${ }^{632}$ contra Damasco, que era pueblo fiel y enemigo del hebreo. Y todo esto del aviso y defensa de la Esposa está muy hermoso, por estar asentado en la silva ${ }^{633}$ de las virtudes que en ella hay, como la torre estaba en el fresco Líbano.

Tu cabeza sobre ti como el monte Carmelo, y las madejas de tu cabeza como la púrpura. El rey atado en las canales ${ }^{634}$.

La última parte de las personas es la cabeza, considerando desde los pies. Y llamamos en este lugar cabeza al casco de ella, donde nacen los cabellos, no toda ella, con el rostro, porque el rostro ya está dicho. Y, por eso, dice la letra: La tu cabeza que está sobre ti. Quiere decir: "Lo último de tu cabeza -que está sobre todo cuerpo, que no hay arriba de ella más de ${ }^{635}$ los cabellos-, esto es tan hermoso, tan gentil, como el monte Carmelo", que es un monte muy alto, en tierra de Israel, bien celebrado en la Sagrada Escritura. Y, para denotar cuán gentil mujer sea esta Esposa, le dicen que su cabeza sobrepuja a las otras, como la cumbre del monte Carmelo a los otros montes.

Después loan la belleza de los cabellos, diciendo que son semejantes a la púrpura antigua, de la cual ahora no tenemos noticia por uso, que era finamente bermeja y relucía desde lejos, como el carmín que los pintores dan sobre oro o plata. Asemejan el cabello de la Esposa a la púrpura porque debía de ser castaño, que, aunque no sea perfectamente rojo, tira más a ello que

\footnotetext{
${ }^{630}$ En el manuscrito, salmo 18 (19). El título de este salmo es Himno a Yavé.

${ }^{631}$ Alusión biblica sin anotación al margen en el manuscrito. $\operatorname{Job}(4,8-9)$.

${ }^{632}$ Estaba... para centinela: construcción paralela a la llamada, en gramática latina, dativo de finalidad.

${ }^{633}$ Silva: selva: abundancia desordenada de alguna cosa (DRAE, 3).

${ }^{634}$ El rey... canales: esta oración no aparece enunciada al principio del capitulo. Por contra, la que aparece en su lugar al principio no aparece en la Exposición. No se trata de un fenómoneno aislado, pues los desajustes de este tipo -asi como las diferencias en la traducción de lo ciiado al principio con lo citado en el parágrafo correspondiente- son relativamente frecuentes.

${ }^{635} \mathrm{De}$ : lo usual actualmente sería que.
} 
a otro color, y porque, en las tierras calientes, como son las de Asia, no se estima el cabello rubio; antes, a los hombres está muy bien el negro y a las mujeres negrc o castaño y otros. Que se le parecen cuando relucen que son sus luces rojas, así como las luces de lo amarillo tiran a lo blanco y las de verde a negro.

Le dicen aquí que son sus cabellos rojos un poco y relucientes, como la púrpura, y que son crespos y ondeados, como canales o regueras de agua que van dando vueltas. Y usan luego de un parlar común de los enamorados, diciendo: "En esas vueltas de tus cabellos tienes tu atado al rey, Esposo y enamiorado tuyo; de los cabellos hace amor la cuerda con que lo liga". Es muy regalada, graciosa y amorosa esta loa. $\mathrm{Y}$ esto parece querer decir a la clara lo que obscuramente suena [en] ${ }^{636}$ la letra, diciendo: El rey atado en las canales -o corrientes-. Como si dijese: "Son tus cabellos como púrpura en cuyas vueltas y ondas está atado el rey, tu Esposo".

Después que particularmente han loado a la Esposa, tornan, según su uso y según uso de las canciones, a loarla universalmente, diciendo: iCuán bella y hermosa eres en tu vista, y cuán graciosa en tus aseos, oh, amada, sobre todas! No hay deleites ni placeres en el mundo mayores que verte y gozarte!" La cabeza que aquí se loa en la Esposa sagrada es el juicio y propósito suyo, porque en esta significación se toma a las veces ${ }^{637}$ en la Escritura Sagrada. Porque, así como la cabeza es lo principal y más alta parte del cuerpo, así la mente y el entendimiento es ${ }^{638}$ lo principal del hombre, [de] donde salen los propósitos y pensamientos, por quien se gobierna toda la vida humana. Y a esto alvide David, diciendo al Señor: Tú quebrantaste las cabezas de los dragones en las aguas ${ }^{639}$. Iguai $\mathrm{es}^{640}$ el juicio y cabeza de la Esposa en esto al Carmelo monte, porque es altísimo juicio, muy empinado a las cosas del cielo, y fuerte en ellas y que no mira las bajezas terrenales, del cual juicio salen los buenos pensamientos y propósitos de la Esposa, que se entienden por sus cabellos, como ya hemos visto; y estos ${ }^{641}$, siendo colorados, del rojo de la claridad, y q le resplandecía su luz delante de los hombres, de manera, que vistas sus buenas obras, que son luz y muestra de los buenos propósitos, sea glorificado el Padre que está en los cielos. Siendo pues tales estos cabellos, hacen fortísimo nudo de amor con que se liga el rey eterno y soberano Esposo, de quien aquí se trata.

Esta tu estatura semejante es a la de la palma, y tus pechos a los racimos. Dije: Yo subiré [etc.].

\footnotetext{
${ }^{636}[E n]$ : según nuestra interpretación, resulta necesaria esta preposición para la construcción de la oración. Existe, no obstante, otra posible interpretacion, dejando el texto tal cual está. En este caso, se trataria de un uso transitivo del verbo sonar, cuyo sujeto seria la letra y cuyo C.D. seria lo que.. Nos hemos inclinado por la segunda opción por considerar este segundo uso un tanto extraño en relación a otras construcciones del texto.

${ }^{637}$ A las veces: modernamente, $a$ veces.

${ }^{638}$ Es: nuevo cas 9 de concerdancia en singular con un sujeto doble.

${ }^{639}$ En el manuscrito, salmo 37 (36). El título de este salmo es La suerte de los buenos y los malos.

${ }^{640}$ Igual es: caso de cuncordancia análogo al anterior.

${ }^{641} Y$ estos: no está clara la sintaxis en este lugar. En principio parece que aqui se da comienzo a una nueva oración, cuyo predicado vendria tras las proposiciones subordinadas incrustadas. Sin embargo, se trata de un nuevo anacoluto, pues no llega a desarrollarse esa proposición principal.
} 
Aunque en el loor de la cabeza se encerraba la gentileza de toda la persona de la Esposa, no dejan las mujeres de tratar de ella, debajo de otra semejanza, la cual es clara y acrecienta mucho a la loa; porque, diciendo que su estatura es como la de la palma, dan a entender que es gentil mujer y muy bien dispuesta, y no torcida ni corcovada ${ }^{642}$ sino como la palma, que siempre crece derecha y no la tuerce ningún peso que encima le pongan. Y dicen que los pechos suyos parecen dos racimos, como si dijesen: "Parecen tus pechos, que cuelgan y están asidos a tu gentil estatura, dos racimos de uvas que cuelgan de una palma donde esté encaramada alguna vid". Y, como quiera que la belleza es por sí amable y pone deseo de gozarla en cuanto puede a quien la conoce, desean las mujeres que han cantado estos loores de la hermosura de la Esposa gozar de ella abrazándola y besándola; y esto es muy común en las mujeres que están contando de alguna otra hermosura que mucho les agradó. Dicen: "Iba tal que se quisiera llegar a ella y darle mil abrazos y besos". Este mismo afecto está en estas palabras que ahora habla(n $)^{643}$ cada cual de aquestas mujeres, aunque lo dicen debajo de la metáfora que tomaron de la palma. Que, habiendo loado su estatura y hermosura de pechos con figura de la palma con racimos, dicen luego:

Dije: Yo subiré a la palma y asiré sus ramas y serán tus pechos como los racimos de la vid, $y$ el olor de tu nariz como el de las manzanas, y tu paladar como el excelente vino, que va a mi amor a las derechas, que hace $(n)^{644}$ rebosar los labios de los viejos.

Quiere decir: "Me has parecido tan bien, joh, hermosa palma!, que querría ser en ti y asirme de tus ramas -entiendo por esto el abrazar, que no es otra cosa sino abrazar a otra persona y asirse de los brazos de uno con el otro-. Y, así abrazándote, luego gozaría de tus pechos, los cuales me serían dulces como racimos de uvas; y luego darte ${ }^{645}$ mil besos y gozar del suavísimo huelgo que sale de tus narices, más oloroso que todas las frutas del buen olor; $y$ gozaría también de la dulzura de tu boca, que me daría mejor gusto que el buen vino da a mi amado cuando más sabor haya en él y más dulce lo siente, que bebe tanto de él que después parla mencando y temblando los labios, como viejo diciendo palabras desconcertadas por causa del vino". Esta es su sentencia; ahora declaremos las palabras.

Será tu paladar como el buen vino, que va a mi amado a las derechas. Quiere decir "concertadamente", y es tanto como si dijese: "Que con mucha dulzura y gusto lo bebe mi amado". Porque, de la misma manera de decir y en tal materia lo usó Salomón en los Proverbios, diciendo: "No mires el vino cuando se torna rojo ${ }^{646}$ y toma su color y va a las derechas". Quiere decir que se cuela muy dulcemente. Y, porque los que beben mucho vino y se toman de él hablan desconcertadamente y muchas palabras, por eso dice que hace rebosar

\footnotetext{
${ }^{642}$ Corcovada: encorvada.

${ }^{643}$ Habla(n): suprimimos ei morfema de plural, pues el sujeto de habla(n) es cada cual. El plural viene dado claramente por el sentido (estas mujeres).

${ }^{644}$ Hace $(n)$ : en plural, fallo de concordancia, pues su sujeto es vino.

${ }^{645}$ Darte: la sintaxis de esta oración es un tanto confusa. Más arriba aparece la forma querria, de la que dependen los infinitivos ser y asir. Después, comienza una nueva construcción, esta vez de condicional (gozaria). Sin embargo, aparece ahora de nuevo un infinitivo (sin un verbo del que dependa, por lo que es de supener que depende del querria de arriba), para pasar, acte seguido, otra vez a la forma condicional.

${ }^{646}$ En el manuscrito, Proberbios, 23. Concretamente, se trata de Porverbios $(23,31)$.
} 
los labios de los viejos. Es lo mismo que decir: "Hace hablar desatinadamente, desatinado", no solamente en las razones, mas $^{647}$ también en las pronunciaciones.

En cuanto al espiritual sentido: que la ánima fiel de estas hijas de Jerusalén que loan a la Esposa, viendo su hermosura, propene que su deseo es estar abrazadas ${ }^{648}$ con esta sagrada Esposa, que es la Iglesia en unión de fe y caridad, y gozar el fruto de los dos racimos, que hemos dicho ser los dos Sagrados Testamentos, cuya sombra y figura son los pechos de la Esposa; y entonces gozar de la suavidad de sus ejemplos, que aquí significa el olor, por los cuales ejemplos y muestras que la santa y católica Iglesia da de sí es de muy buen olor a las gentes, dando noticia de Cristo, conforme [a] aquello del Apóstol: Somos buen olor de Cristo $^{649},(y)^{650}$ el que de esta manera está abrazado con la Esposa y goza de la suavidad de su olor, alcanzando los besos de su boca, que son la santísima doctrina suya, participada de su Esposo, la cual da más dulzura y agrada más al apetito que el más gentil vino del mundo.

Yo soy de mi amado, y sobre mi su deseo.

Viéndose la Esposa loar tanto y desear, no se ensoberbece; antes, responde con gracia, refiriéndolo todo a la excelencia y divinidad de su Esposo, y dice: "Toda cuanta yo me ${ }^{651}$ soy y toda mi belleza no soy ${ }^{652}$ mía ni por mí valgo cosa, sino toda soy de mi amado Esposo y estoy obligada a cumplir su deseo y voluntad, y tenerle toda obediencia. De manera que mi hermosura de él viene, y no tengo de abrazar ni amar a otro que a él y a quien suyo fuere; quien a mí amare a él ha de amar, pues yo no tengo cosa ni soy sin él, y a él ha de obedecer y servir". Es muy gentil respuesta y que en breves palabra[s] encierra grande sentencia.

¡Ven, amado mio! Vámonos al campo, pasemos las noches en las grajas, levantémonos de mañana a ver si florece la vid.

Habiendo conocido la Esposa cómo todo su bien y honra le viene[n] del Esposo y que en gozar de él consiste todo su placer, deseosa por esto de no apartarse de él, antes hacerse muy familiar, y procurando también que en este gozo ningún estorbo se le interponga, convida a su Esposo con grande instancia a lo que antes él le había rogado, que era irse al campo a gozar el uno del otro, y sus palabras son estas: " $¡ \mathrm{Oh}$, Esposo amado, cuya soy yo toda y en quien tengo todo mi bien! Ven ahora, que ya estoy desengañada, que no hay más que desear que a ti; por tanto, querría gozar de ti sin impedimento ninguno. Apartémonos de las ciudades y lugares donde hay tantos bullicios y desasosiegos, vámonos a la quietud del campo, donde, estando sola contigo, estaré la más acompañada, la más rica, la más contenta del mundo; allí será nuestro ejercicio cual suele ser el de los rústicos, que sin ruido viven: andaremos todo el día por el campo, dormiremos las noches en las casas de las granjas y levantarnos hemos de

\footnotetext{
${ }^{647}$ Más: equivalente a sino.

${ }^{648}$ Abrazadas: dado que el sujeto de la oración es la ánima fiel de estas hijas de Jerusalén, se da una actitud titubeante a la hora de concordar en singular 0 en plural.

${ }^{649}$ En el manuscrito, Il Carta a los Corintios, 2. Concretamente se trata de Il Carta a los Corintios (2, 14-16).

${ }^{650}(Y)$ : de nuevo un fenómeno ya aparecido en varias ocasiones: la conjunción debe ser suprimida, dado que la proposición que la sigue no está coordinada con la anterior sino subordinada a ella.

${ }^{651} \mathrm{Me}$ : uso enfático.

${ }^{652}$ Soy: en primera persona, concuerda únicamente con el primero de sus sujetos.
} 
mañana a visitar nuestra hacienda, donde recibiremos una alegria increible viendo cómo en la viña florecen las vides y cómo se limpia el agraz en los huertos, cómo brotan los granados y muestran la flor los otros árboles.

\section{Alli te daré mis amores.}

"Alli no habrá cosa que desear, ni habrá a quien quiera sino a ti. Tú gozarás de mis amores, teniéndome siempre a tu lado en tu servicio".

\section{Las mandrágoras dieron su olor.}

Quiere decir: "Después nos andaremos por el jardín cogiendo las olorosas mandrágoras cuando están ${ }^{653}$ floridas, las cuales, así como son contrarias a la memoria y causan olvido a quien de ellas usa, así yo me olvidaré de todas las cosas del mundo teniéndote a ti, amado mío, riqueza mía y honra mía, conmigo, y cogeremos de las flores y hierbas preciadas, de las cuales nos haremos luego mil presentes y guirnaldas".

\section{$Y$ en nuestras puertas todos los hermosos frutos nuevos y viejos te guardé.}

Prosigue contando la buena, quieta y abundante vida del campo en que desea estar con su Esfoso y dice: "Después de estos ejercicios, no nos faltarán buenos y dulces mantenimientos para sustentación de nuestra vida, porque, de las puertas adentro, sin ir a comprar cosa, tendremos las más bellas frutas que el campo suele producir, así de las frescas guindas, cerezas, ciruelas, manzanas y todas las de esta suerte, como también de las anejas que [se] pueden conservar, que son vino, tocino, trigo, aceite, con todas las otras cosas de que suele abundar la vida rústica; y esto sola yo seré la que te lo guardaré y aderezaré". Estas palabras son todas del estilo amorosas, porque, ordinariamente, los enamorados no quieren ni piden cosa para sí, sino todo lo dedican para quien bien quieren; y por eso dice: Los guardé para ti.

Desea mucho la espiritual Esposa coger gran familiaridad con Dios, su Esposo; y, para esto, tiene por cierto medio el apartarse de los desasosiegos de la carne y de los bullicios mundanos, que le dan pena, ni le estorben ${ }^{654}$ el continuo gozo del Esposo. Y, como quiera que esto se alcance por la gracia del Esposo, como dice San $\mathrm{Pablo}^{655}$, no por las fuerzas humanas, que no pueden librar el cuerpo de la muerte, que es el principio de todas estas turbaciones; por eso ${ }^{656}$, la Esposa le ruega que la saque consigo a vivir en la quietud del espiritu, que es entendida por el campo, y que allí vivan el día y la noche y todo el tiempo, y entonces ella le dará todos sus amores enteros, sin que tenga[n] parte en ellos ei mundo ni el demonio, porque ya andará con ella Cristo, y la terná ${ }^{657}$ mudada en nueva vida de justicia, santidad y verdad, dejando al viejo hombre con sus obras y negaciones. Y eitonces sus ejercicios serán predicar y alabar $\mathrm{el}^{658}$

\footnotetext{
${ }^{653}$ Están: habiéndose usado un futuro imperfecto en la proposición principal, seria aqui esperable un presente de subjuntivo.

${ }^{654}$ Ni le estorben: se da aquí un claro salto sintáctico, pues esta construcción exigiria otra anterior que fuera final y negativa. Si bien resulta aceptable por el sentido, resulta incoherente desde el punto de vista sintáctico.

${ }^{655}$ Alusión biblica sin anotación al margen en ei manuscrito. Romanos $(8,12-13)$.

${ }^{656}$ Por eso: retoma la construcción comenzada tres lineas más arriba $(Y$, como quiera...)

${ }^{657}$ Terná: ver nota $i 61$.

${ }^{658}$ El: al.
} 
enamorado Esposo y enseñar su ley a los otros que no la saben y gozarse viendo el provecho y acrecentamiento de los fieles, que se entiende por la uva en cierne y por el agraz limpio. $Y$ veríamos entonces la mandrágora, que, como hemos dicho, da un cierto fruto, como avellanas, que causa olvido en quien lo come; y aquí se entiende por la predicación, que a los que la reciben hace(n) ${ }^{659}$ olvidar las cosas del mundo y buscar las de Dios. [Como si dijese]: "Veremos, pues, cómo esta mandrágora de buen olor hace su efecto en los fieles, y todos los frutos que en esta nuestra heredad se criaren, viejos y frescos, todas las buenas obras, todos los que bien obran, así de los antiguos como de los que nuevamente se recogeren, todos serán en tu servicio y no para otro.

\footnotetext{
${ }^{659}$ Hace $(n)$ : suprimimos el morfema de plural, pues su sujeto es predicación. La aparición del plural puede, probablemente, deberse a estar situado este verbo junto a reciben.
} 


\section{CAPíTULO [VIII] ${ }^{600}$}

¿Quién te me dará como hermano mio, que mamases los pechos de mi madre? Hallarte ya fuera, besariate y también no me despreciarian, meterte ${ }^{661}$ ya en casa de mi madre, enseñariasme, hariate beber el vino adobado y del mosto de las granadas mías. Su izquierda debajo de mi cabeza y su diestra me abrazará. Yo os conjuro, hijas de Jerusalén, ¿por qué despertaréis, por qué desasosegaréis [a] la amada hasta que le agrade? ¿Quién es esta que sube del desierto sustentada en su amado? Debajo del manzano te desperte; alli te parió tu madre, alli estuvo de parto la que te parió. Ponme como sello sobre tu corazón, porque el anor es fuerte como la muerte, dura como el infierno la emulación, los sus carbones son carbones de llama de Dios. Muchas aguas no pueden matar el amor, ni los rios lo pueden anegar. Si diere el hombre todos los haberes de su casa por el amor despreciar, lo despreciarán. Hermana es a nos ${ }^{662}$ pequeña y tetas no tiene ella. ¿Qué haremos a nuestra hermana cuando se hablare de ella? Si hay pared, edificarémosle un palacio de plata y su puerta fortalecerémosla para ella con tablas de cedro. Yo soy muro y mis pechos como torres. Entonces ven sus ojos como aquella que halla paz. Tuvo una viña Salomón en Baal-Hamón ${ }^{663}$. Entregó la viña a las guardas y que cada cual traiga por el fruto mil monedas de plata. La viña mia, que es mía, delante de mi está; mil para ti. Salomón, y doscientas para los que guardaren sus frutos. Estando tú en el huerto y los compañeros escuchando, haz que yo oiga tu voz. Huye, amado mío, y sé semejante a la cabra montesa y a los ciervecitos sobre los montes de los olores.

\section{[EXPOSICIÓN]}

¿Quién te me dará como hermano, que mamases los pechos de mi madre?

Una de las cosas que en el verdadero amor hay es el crecimiento suyo, que, mientras más de él se goza, más se desea y más se precia; al contrario es el amor falso y vil, que es fastidioso y pone una aborrecible hartura. Hemos visto muy bien los procesos de este gentil amor que aquí se trata. Como, al principio, la Esposa, careciendo de su Esposo, deseaba siquiera algunos besos de él, después de haber alcanzade la presencia, habla y regalos, y los abrazos suyos, desea tenerlo en el campo consigo; $y$, ya que en el campo le tenía a sus solas, gozando de él

\footnotetext{
${ }^{660}$ [VIII]. realizamos esta la adición y suprimimos lo que hemos eicontrado en el manuscrito $\left(8^{\circ}\right)$ en un intento de homogeneizar los titulos de los capítulos.

${ }^{661}$ Hallarte... meterte: extraña alternancis de infinitivos y condicionales.

${ }^{662}$ Es a nos: construcción paralela a la latina sum +dativo, equivalente a tenemos.

${ }^{663}$ Baal-Hamón: en el manuscrito encontramos las formas Radahnon, Bahalmon y Bahal-hamon.
} 
donde no hubiese quien los impidiese, querría tener más licencia de nunca apartarse de él, sino en el campo y en el puebio siempre andar junta a él y gozar de sus besos en todo lugar y en todo tiempo, como aquella que había gustado la suavidad de los besos de su Esposo y no querría dejar siempre de gozarlos. Y, para mostrar este deseo la Esposa y la nanera como querría curnplirlo, comienza su pregunta diciendo: ¿Quién te me dará?. Esto es en lengua hebrea oración de ánimos deseosos y vale tanto como "ojalá" o "plugiese ${ }^{664}$ a Dios". Y así es aquello que dice Jeremías: ¿Quién dará agua a mi cabeza? ${ }^{665}$ Y David dice: ¿Quién me dará alas, como paloma, y volaré? ${ }^{666}$.

Dice, pues, la Esposa que, estando a sus solas, sin conversación de otra gente, ella goza de los besos de su Esposo y se huelga y alegra mucho con él; mas, cuando está delante gente, tiene vergüenza, como la suelen tener las mujeres de besar a sus Esposos; y que ${ }^{667}$ le es gran pérdida aquella, porque siempre querría estar coigada de sus besos, sin desasirse un punto, que pluguiese a Dios ella pudiese tenerlo y tratar con él como con un niño pequeño, hermano suyo, hijo de su madre, que aún mamase; que, como ella lo hallase en la caile, arremetería con él y le daría mil besos delante de cuantos allí estuviesen; porque esto es muy usado de las mujeres con los niños y no son notadas de esto y no tienen empacho de $^{668}$ hacer estos regalos y mostrarles este amor públicamente.

Esta facilidad desea la Esposa tenei en los besos de su Esposo y en gozar de él. Y, durando aún en la semejanza que ha puesto del niño, prosigue con su deseo, diciendo: "En teniéndole yo en casa, con mil besos y abrazos le daría a beber dulce vino, adobado con miel y especies y otras cosas", que los antiguos usaban para que fuese más suave y menos dañoso; y este era más género de regalo que de ordinaria bebida. "Y darte ya también arrope de granadas"; porque con todas estas cosas dulces se huelgan los niños, y sus madres y hermanas tienen gran cuidado de regalarlos así. Y lo que dice enseñariasme quiere decir: "Estando tú todavía en la figura de niño, diríasme nill cosas de las que hubieses visto y oído por la calle y mil cantarcicos"; porque los niños todo cuanto ven y oyen, todo lo parlan, bien o mal, como ellos aciertan; y de esto reciben gran regocijo los que los crían y aman.

[En] cuanto al espiritual sentido de estas enamoradas palabras, entenderemos que los enamorados de Dios tienen sus grados en el amor. Primero lo aman inducidos del buen conocimiento que de él tienen, así por sus obras universales como por los particulares beneficios que de él reciben. Y así lo muestra el profeta largamente en el salmo que comienza: Bueno es confesar al señor ${ }^{669}$. Estos tales enamorados desean sus besos, que es la perfecta unión con él. Después van creciendo en este amor, amándolo cada vez mucho más, porque reciben nuevos y suavísimos regalos, y sienten grandes gustos espirituales y gozan de él como

\footnotetext{
${ }^{664}$ Plugtiese: forma arcaica de pretérito imperfecto de subjuntivo dei verbo placer.

${ }^{665}$ En el manuscrito, Jeremias, 9 . Se trata de un error. Corresponde a Jeremias $(8,23)$

${ }^{666}$ En el manuscrito, salmo 54 (55). El titulo de este salmo es Canto de paz entre las luchas.

${ }^{667}$ Que: completiva dependiente de dice.

${ }^{668}$ Tienen empacho de: hoy más habitual en.

${ }^{669}$ En el manuscrito, salmo 91 (92). El titulo de este salmo es Al Dios justo v providente.
} 
si estuviese presente. Los que de esta manera van aprovechando vienen a punto que se van a apartar al campo con él; quiero decir que, a sus solas, cuando otros no los ven, en sus retretes, en el encerramiento de su pecho, están hablando y gozando de él muchas veces. Mas no están en tanta perfección que sufran con gran ánimo la vergüenza del mundo, las afrentas y deshonras, y el ser notados o de hipócritas o de escandalosos, y otros trabajos que la cruz tiene y trae consigo. Porque todavía anda un poco flaca la carne, tienen respeto a cumplir con sus deudos, con sus familias, no sólo [en el] cumplimiento necesario al que son obligados sino otro de no darles qué decir, de contemporizar con ellos y con los demás. En este estado de amor se hallaban los discípulos cuando, amando al señor grandemente, tenían cerradas las puertas por miedo de los judíos ${ }^{670}$, y otros muchos exemplos tales se hallan en la Escritura Sagrada. Mas, cuando, últimamente creyendo, amando y adorando, vienen [a] aquella perfección de gracia que andan ya en espíritu, santidad y verdad viviendo vida espiritual y fiel como viven los justos; no teniendo respeto a cosa alguna, sino en público y elı secreto gozando de la suavidad de estos amores, entonces son hermanos de Cristo, hijos perfectos de Dios, como lo manifiesta el Apóstol, diciendo: Los que son gobernados por el espiritu de Dios, estos hijos son de $\operatorname{Dios}^{671}$. Y el mismo dice que C-isto tiene muchos hermanos y él es el primogénito entre ellos.

Esto es lo que desea la Esposa alcanzar; y, de esta manera, en pút'ico y en secreto [amar] a su Esposo, sin curar [de] que nadie de ella diga; antes, entonces todos callan y ni tienen qué reprender aunque quieran, porque el espíritu de verdad que en ella está les atapa ${ }^{672}$ a todos las bocas y quedan convencidos, $o^{673}$ tropiezan en sus mismas malicias. Al tal estado y grado de amor había subido el Apóstol cuando no solamente no temía a las afrentas ni injurias y aflicciones, mas ${ }^{674}$ de buena gana se gloriaba y regocijaba en ellas.

Y, cuando ella está ya de esta suerte empinada en el amor, mete al su Esposo en casa de su madre, que es la congregación pecadora, hija de Adán, de la cual tuvo origen esta Esposa porque de los hijos del viejo Adán se escogió, tornando los hijos de él nuevo- y lo mete en casa de su madre por la predicación, para que su madre lo abrace y para que allí oigan su doctrina y sean enseñados de él, porque la doctrina de Dios es muy gustosa y nunca se harta quien una vez la prueba. Y una de las grandes mercedes que este divino desposado hace, así a los perfectos miembros de su Esposa como a los imperfectos, es el continuo pasto de su doctrina y sabiduría, de que ellos nunca se hartan, como lo confiesa David, diciendo: Ansiada está mi ánima deseando la doctrina de tus jistificaciones en todo tiempo, siempre $^{675}$; y esta sentencia repite muchas veces en aquel salmo.

\footnotetext{
${ }^{670}$ Por miedo de los judios: lo normal, actualmente, seria a los judios. La construcción que aqui encontramos es paralela a la conocida en sintaxis latina como genitivo objetivo.

${ }^{671}$ En el manuscrito, Carta a los Romanos, 3. Concretamente se trata de Carta a los Romanos (3, 21-26).

672 Atapar: Lapar.

${ }^{673} \mathrm{Ni}$... o: nuevo caso de anacoluto, dándose un cambio de construcción sintáctica.

${ }^{674}$ Mas: equivalente a sino.

${ }^{675}$ En el manuscrito, salmo 118 (119). El titulo de este salmo es Encomic de la ley divina.
} 
$\mathrm{Y}$, siendo enseñada de aquesta manera la Esposa con el gozo de su Esposo y su continua presencia, ie da a beber el vino adobado y el arrope de las granadas. Dar a beber, en la Sagrada Escritura, algunas veces es dar contentamiento y mucha alegría a otro, como lo dice David del Señor: En el agua de la hartura me abreva ${ }^{675}$. Así, la Esposa da a beber a su Esposo vino adobado con las obras conformes a la doctrina, y este es el adobado del vino, porque ya hemos visto que el vino significa la doctrina; $y$, con esta doctrina, bien guisada con las obras del que la oye, se contenta y alegra mucho el Esposc, y también con el arrope de granadas, que es la dulzura de la caridad; con tales regalos se contenta mucho el soberano Esposo. A estos tales llama San Pablo ofrendas espirituales y agradables a Dios ${ }^{677}$. Y estas le ofrecen más excelentemenie cuando está tan familiar el Esposo, como aqui lo demanda y como lo ha sentido y recibido la misma Esposa, en muchos de sus miembros, como fueron los Apóstoles, y otros muchos que fueron y son, que han gozado de estos besos pública y secretamente, a los cuales nos remitimos en la declaración entera de su lugar ${ }^{678}$, y de otros semejantes, porque saben y han experimentado bien aquello, que ninguno sabe sino el que lo recibe.

\section{Su izquierda debajo de mi cabeza y su derecha me abrace.}

Las palabras que la Esposa arriba decía, en que su deseo era [estar] en el campo, donde a sus sclas gozando de él estuviese, como vimos ${ }^{679}$. Y, estando en este deseo, viendo que le faltaba aquella facilidad de gozar totalmente de su amado, se desmaya de amorosa congoja, como en semejantes efectos otras veces lo ha hecho. Y, porque para sus pasiones todas tiene por único y solo remedio a su Esposo, conforme a la demanda del otro desmayo ${ }^{680}$. Y ahora, estando el Esposo con ella, es de creer que la favoreció con cual amoroso abrazo, porque arriba, cuando se desmayó, no estaba el Esposo junto a ella, aunque luego acudió a favorecerla. Y, porque la letra y el espíritu de esto ya se declaró ${ }^{681}$, y también lo que tras esto vendrá, no nos detendremos más que en declarar un lugar de la letra, que es este:

Conjúroos, hijas de Jerusalén, ¿por qué despertaréis y por qué alborotaréis a la amada hasta que le agrade?

La pregunta ¿por qué, por qué? vaíe tanto como iogar vedando; y lo mismo quiere decir ¿por qué despertaréis, por qué alborotaréis? que si dijera "no alborotéis, no despertéis". Y tal como esto es lo que dice el profeta: ¿Por qué te apartaste. Señor, tan lejos? ¿Por qué escondes

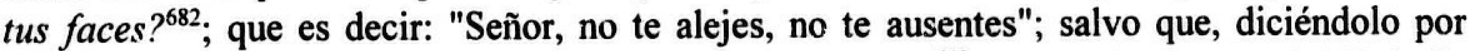
pregunta, pone más compasión, como si dijera: "¿No habéis ${ }^{683}$ lástima de despertarla? Dejadla

\footnotetext{
${ }^{676}$ En el manuscrito, salmo 22 (23). El titulo de este salmo es Canto al divino pastor.

${ }^{677}$ Corintios $(12,1-11)$

${ }^{678}$ Esta idea se recoge, como señala el manuscrito en anotación marginal, en Apocalipsis, 2. Se desarrolla a lo largo de todo el capitulo.

${ }^{679}$ Las pcilabras... vimos: manifiesto anacoluto.

${ }^{680}$ Y, porque... desmayo: de nuevo nos encontramos con un fuerte anacoluto. A la vista del pasaje paralelo del Comentario según la letra - que resulta casi literal-, parece ser un salto del copista. He aqui ese pasaje: "Y, porque para todas sus pasiones tiene por único remedio a su Esposo, al tiempo de su desfallecimiento demanda el regalado socorro del abrazo suyo, conforme a la demanda del otro desmayo [...]".

${ }^{681}$ Declaró: en singular, concuerda únicamente con uno de sus sujetos.

${ }^{682}$ En el manuscrito, salı $\quad 1$ título de este salmo es Dioi triunfador sobre los impios.

${ }^{683}$ Haber: poseer, tener una cosa (DRAE, 1). Acepción desusada.
} 
dormir y pasar su desmayo hasta que torne de suyo a entrar en sí". Ruega, pues, a sus compañeros los fieles que no la molesten, no perturben su reposo, sus gustos amorosos, no la calumnien ni pongan disensión, sino la dejen gozar de su amor simplemente y a su sabor. Y esto, [en] cuanto a lo espiritual, es mucho de notar el cuidado que tiene el Esposo de esto y cuán presto lo avisa y amonesta, de donde podemos bien conjeturar que le dan gran enojo los que lo contrario hacen.

También consideramos aquesto: que, cada vez que la Esposa se desmaya, después que ha tornado en sí, sube en perfección de amor, porque el Esposo, que está cerca de ella y la ama tanto, no consiente que pene mucho en aquel deseo que la hacía desmayar y, gozoso de verla tan enamorada suya, presto le concede nuevos favores de amor.

¿Quién es esta que sube del desierto en su amado? ${ }^{684}$ Debajo del manzano te desperté; alli te parió tu madre, alli estuvo de parto la que te parió.

El primer verso es paréntesis o sentencia encajada entre las hablas de los dos Esposos, y son palabras de las personas que veían cómo los dos amantes se van juntos desde el campo a la ciudad [y] la Esposa venía muy pegada y abrazada a su Esposo. Porque, después que ella desmayó y tornó en sí, se finge subir a ia ciudad y ella, con más atrevimiento que antes, se iba muy junta y abrazada a su Esposo, sin tener el respeto que primero tenía, porque el amor le daba alientos para vencer todo esto; y parte fue para ello aquel desmayo. Y esto es cosa muy aguda en este caso de amor y punto muy de notar: cada vez que alguno, sobre algún negocio [que] le daba pasión, deseándolo o de otra manera, se desmaya o pierde el juicio; cuando torna en sí, tiene nuevo ánimo y atrevimiento en aquel negocio. $Y$ esto es muy probado en los que han estado sin seso, que después tornan otros hombres diferentes de los de antes; y vemos que el que enloqueció por algún caso de honra, después que torna en su libre poder, no estima aquello: y de estas hay cada día muchas experiencias. Aunque se echa más de ver en los locos que en los que por algún rato han estado transportados, porque, como los otros estuvieron más tiempo, hubo lugar de hacer mayor mudanza y mostrarse más ${ }^{685}$; en esotros ${ }^{686}$, no tanto. Mas ahora bien se muestra aquí haberla habido grande, pues, la [que] poco antes se congojaba ${ }^{67}$ por no osar públicamente gozar de sus amores con su Esposo, viene ahora delante de todos tan asida y firmada ${ }^{688}$ en él que los otros con admiración preguntan: "¿Quién es esta que sube del desierto tan asida y junta a su Esposo que viene como sustentada toda sobre él?".

El úlimo y más adelantado paso de este divino amor dijimos ser aquel con que la Esposa viene en tanta perfección que pública y [no] secretamente manifiesta sus amores, sin tener respeto a cosa de la tierra. Este deseaba denantes y pedía de su Esposo, que le puede él solo dar los alientos para ello. Y este paso muestra aquí haber ya dado, pues que ya viene sustentada y

\footnotetext{
${ }^{684}$ En su amado: en el principio del capitulo leemos sustentada en su amado.

${ }^{685}$ Más: la tilde muestra que hemos interpretado esta forma como un adverbio. Podria, no obstante, interpretarse también como una conjunción, que uniria los dos elementos que, según la intepretación por la que nos hemos inclinado, se encuentran yuxtapuestos.

${ }^{686}$ Esotros: forma antigua de demostrativo, por esos otros.

${ }^{687}$ Congojar: acongojar.

${ }^{688}$ Firmada: afirmada.
} 
andando por los $^{689}$ pasos, que el espiritu de su Esposo ia guía y en él se sustenta ${ }^{690}$, como dice el Apóstol. Y así sube del campo, que aquí llama desierto, adonde ${ }^{691}$ gozaba de él, a gozar de él públicamente y dar muestras claras de este amoroso gozo al mundo y lucir entre todos los ctros, como el sol y la luna hacen en el mundo ${ }^{692}$, con gran resplandor obrando y haciendo obras más extremadas y heroicas que antes. Y, así como el gozo es mayor y el gusto de los amores, así las palabras son más amorosas y las muestras evidentes, como luego veremos.

Dijimos que desierto en este lugar, a la letra, significa lo mismo que "campo", porque así muestra que ellos no tornaban a la ciudad sino del campo, donde había huertas y viñas con árboles y granjas; también porque este vocablo desierto no siempre significa entre los hebreos lugares yermos y que carecen de habitación y de pastos y verduras; antes, muchas veces significa lugares anchos y llanos en el campo, donde, aunque no haya tan espesas moradas de gente, no faltan a lo menos algunas $y$, juntamente, hay pastos y abrevaderos. Porque, en la Sagrada Escritura, muchos pueblos y ciudades se cuentan estar ${ }^{693}$ asentada $^{694}$ en el desierto, que quiere decir en campo llario; y, así, leemos que Moisés llevó el ganado de su suegro al desierto ${ }^{695}$, más adentro que antes estaría; y, en Josué, [que] a los del tribu de Judá les cupieron seis ciudades del desierto ${ }^{696}$.

Debajo del manzano te desperté; alli te parió tu madre, alli estuvo de parto la que te parió.

Esto es trasladado al pie de la letra de lo hebreo; el latino dice: Alli fue corrompida tu madre, alli fue violada la que te parió.

El sentido, a la letra, de estas palabras parece ser que la Esposa, habiendo tornado en sí del pasado desmayo y, con mayor atrevimiento, comenzando a gozar de su Esposo (el cual, en la mayor parte de esta canción, se pinta rústico pastor, conforme a la imaginación que el autor de ella tomó), viniendo ahora con él muy junta y abrazada, se acuerda del principio de sus amores, de los cuales ella ahora tan dulcemente goza; $y$, acordándose, lo cuenta con grande alegría. Porque una de las condiciones del amor es que a los enamorados hace de gran memoria y, en un purto, se acuerda[n] de todas cuantas cosas le[s] han pasado [desdie] su principio hasta el fin; ante[s], nunca jamás se les olvida cosa, por pequeña y liviana que sea, y siempre les parece tener delante un retablo de toda la historia de sus amores, acordándose del tiempo, del lugar y del punto de cada cosa. Y, así, en sus dichos y escritos, usan muchas veces

\footnotetext{
${ }^{689}$ Los: el sentido exigiria los sus o simplemente sus.

${ }^{690}$ En el manuscrito, Carta a los Romanos, 3. Esta idea se desarrolla a lo largo de todo el capitulo.

${ }^{691}$ Adonde: donde.

${ }^{692}$ Esta idea se recoge, como señala el manuscrito en anotación marginal, en Carta a los Filipenses, 2 . Se desarrolla a lo largo de todo el capitulo.

${ }^{693}$ Se cuentan estcr: de nuevo sintaxis influenciada por la latina. Este caso es un ciaro ejemplo de la llamada construcción personal del infinitivo.

694 Asentada: claro fallo en la concordancia, pues, no sólo no concuerda con los dos sustantivos a los que califica (en masculino plural), sino que ni siquiera concuerda con el segundo (en femenino plural), que seria lo esperable.

${ }^{695}$ Alusión biblica sin anotación al margen en el manuscrito. Éxodo $(3,1)$.

${ }^{696}$ En el manuscrito, Josué, 14. Se trata de un error. Esta idea se recoge en Josué $(15,1-63)$
} 
de las cosas pasadas para su propósito, unas veces contándolas sin parecer que hay para qué y otras que se ve claro el fin de su intención. Y, como la retórica de los enamorados consiste más en lo que hablan dentro de sí que en lo que por la lengua publican, muchas veces traen lo primero a la postre y lo último al principio, como vemos en este lugar que ${ }^{697}$ la Esposa dice el principio de sus amores tanto al fin de la canción, que parece que lo debía haber contado antes si de ello querría hacer mención. Como hemos dicho, en ellos no hay antes ni después en estas cosas, que todo lo tienen presente en su fantasía; y ahora, embebida en la suavidad del amor que delante tenia, pensando unas cosas y callándolas, dice otras. $\mathrm{Y}$ es lo que dice esto: " $\mathrm{iOh}$, amado mío Esposo!, que parece que ahora te veo la primera vez que te moví a amarme y a que tratases este desposorio conmigo; y esto era estando debajo de un árbol en las huertas, y en aquellas huertas, debajo de aquel árbol, te parió tu madre".

$Y$ alli estuvo de parto la que te parió. Repite la sentencia, como suele. Quiere decir: "No eres extranjero, porque de allí eras natural y te había parido tu madre; y allí te desperté y te moví a amarme. Y, porque (de) $)^{698}$ este amor me ha hecho tan dichosa, gozando del bien que por aquel gozo, bendigo aquel día y aquella hora y aquel lugar donde tú me amaste". Esta es la sentencia de la letra en cuanto podemos alcanzar. Iba muy conforme a las otras razones que en este caso suelen los enamorados decir.

[En] cuanto al espíritu ${ }^{699}$, parece $[\ldots]^{700}$, aunque está más claro lo que significa este misterio, y es que la Esposa. viéndose tan levantada en la cumbre de todo el bien que por los favores que de su Esposo ha recibido, siendo ensalzada de pecadora, hija de ira justa e hija de Dios, con gran maravilla y danco gracias y bendiciendo este hecho, entre sí cuenta el proceso de estos amores, diciendo: "Cuando yo estaba debajo de aquel árbol vedado, que comiendo de él tragué la ponzoña de mi perdición y caí en la red de mi enemigo, entonces te moví a ti para que me amases y determinases (de) ${ }^{701}$ sacarme de aquel gran peligro; y esto se había de hacer amándome tú y desposándote conmigo y celebrando las bodas donde te habías enamorado de mí, quiero decir, en otro árbol, donde tú la celebraste con gran dolor de tu madre y gran compasión de la que te parió, la cual padeció gravísimos dolores viéndote en aquel árbol, cuales lo suelen padecer las que están de parto".

Y esto en espíritu ${ }^{702}$, se entiende por la sagrada madre de Cristo, Virgen María señora. Y la Esposa, para contar la manera de las bodas que se acabaron en la pasión de Cristo y mostrar cuán grandes tormentos sufrió, entonces dice de los dolores de su madre, porque así se entiende bien la cosa. Que cierto es que, si la madre estaba en gran pena, la causa era ver a su hijo penado y en vehementes $[\mathrm{y}]$ intensos dolores puesto. $\mathrm{Y}$ así celebraron y trataron estas

\footnotetext{
${ }^{697}$ Que: construcción ambivalente. La forma que podria interpretarse, bien como relativa (con la preposición en, dependiendo de lugar) bien como completiva (dependiendo de vemos).

${ }^{698}$ (De): suprimimos por resultar incoherente sintácticamente. Tendría sentido si el verbo estuviera en primera persona.

${ }^{699}$ Espiritu: en el manuscrito aparece con la abreviatura spi.

${ }^{700}$ Parece [...]: probablemente haya aqui una mutilación del texto.

${ }^{701}(\mathrm{De})$ : como en casos anteriores, uso de la preposición de con el complemento de verbos transitivos.

${ }^{702}$ Espiritu: en el manuscrito aparece con la abreviatura spu.
} 
bodas que ${ }^{703}$, donde el Esposo se enamoró de la Esposa, allí vino a tomarla por mujer. Quiere decir que en [ese] árbol fue la perdición de ella, y entonces determinó (de) ${ }^{704}$ remediarla y en el árbol vino a labrarla y matar la muerte que en ella reinaba y poner en ella la vida eterna, haciéndola una misma cosa consigo en aquellas admirables bodas que nunca se harta de alabar, palabras en las cuales su sagrana madre recibió extrañísima pena. Porque esto significa aquí el parir a la letra, que otra cosa no quiere decir que la $^{705}$ parió allí sino que allí penó gravísimamente viendo en él ser hechas [las] crueldades que vio. Y en esta significación se toma el vocablo "parir" en muchos lugares de la Escritura, como es en aquel salmo: Tendrán dolores como las que están de parto ${ }^{706}$. Y en Isaias: Tendrán dolores como las que paren ${ }^{707}$. Y en el mismo vocablo hebreo habal, que declaramos "parir", más significa los dolores de la que pare, no el mismo parto.

Ponme como sello en tu corazón y como sello en tu brazo, porque el amor es fuerte como la muerte, dura como el infierno la emulación, los sus carbones son carbones de llama de Dios. Muchas aguas no pueden matar ei amor, y los rios no lo pueden anegar. $Y$, si diere el hombre todos los haberes de su casa por el amor desprecia[r], lo despreciarán.

El gran misterio de este lugar es muy digno de considerar. Que, hasta aquí, el Esposo bien ha mosirado ei amor que a su Esposa tenga, mas no del todo abiertamente, que unas veces la regalaba antes que entrásemos y otras la loaba y algunas se le mostraba esquivo (fuese) [y] ${ }^{708}$ airado, porque ella [fuese] poco a poco conociendo la falta que sin él tenía; ahora, después que ella ha venido a amarlo con gran vehemencia y después que él le ha comunicado los grandes tesoros de su gracia $(y)^{709}$ dándole tan grandes dones, le muestra y le da a entender cuanto la ama. Como si dijera entre sí: "Ahora es tiempo de avisar a esta mi Esposa de mi amor y de amonestarle, que no pierda el amor que me tiene". Y le dice estas palabras, las cuales pronuncia con grande y vehemente afecto en esta sentencia: ";Oh, Esposa carísima ${ }^{710}$ a mí! Ten cuenta ${ }^{711}$ con cuánto te amo y con cuánto he penado por tus amores, y nunca me dejes de tu corazón, nunca ceses de amarme, de manera que tu corazón tenga esculpida e impresa en sí mi imagen y no la de otre ninguno. Haz que yo esté tan simple y tan firme en tu corazón como está la figura en el sello, porque la figura del sello no es más de una siempre, ni se muda hasta que se destruye el mismo sello, y todo cuanto imprimen con él sale de una misma imagen; así quiero yo que tú me tengas en tu corazón, corno sello, que no esté en él otra imagen sino la

\footnotetext{
${ }^{703}$ Asi... que: secuencia modal.

${ }^{704}(D e)$ : caso idéntico al sen̂alado en la página anterior.

${ }^{705} \mathrm{La}$ : se trata de un error: la en lugar de lo.

${ }^{706}$ En el manuscrito, salmo 47 (48). El titulo de este salmo es Canto de Jerusalén liberada

${ }^{707}$ En el manuscrito, Isaias, 13. Concretamente se trata de Isaias $(13,8)$

${ }^{708}$ (Fuese) [y]: realizamos esta supresión y esta adición con vistas a intentar dotar de sentido la frase. Probahlemente se deba a un lapsus del copista, y este fuese sea el verbo que echamos en falta en la siguiente proposición. Seguimios, como en casos anteriores, el pasaje paralelo del Comentario segín la letra: "que unas veces la regalaba antes de ahora y otras la loaba y algunas se le mostraba esquivo y airado, porque ella fuera poco a poco conociendo $[\ldots] "$.

${ }^{709}$ (Y): suprimimos la conjunción, pues no se trata de dos proposiciones coordinadas, sino que la segunda está subordinada a la primera.

${ }^{710}$ Caro: Amado, querido (DRAE, 4).

${ }^{711}$ Ten cuenta: más abajo podemos leer ten cuenta de. Expresión paralela a la actual tener en cuenta.
} 
mía, que no impriman los pensamientos en tu corazón [a] otro sino a mi, y primero lo hagan pedazos que le puedan hacer mudar el retrato que en sí tiene mío. Y no sólo deseo que me tengas en tu corazón y en tus pensamientos, $\operatorname{mas}^{712}$ también de fuera que no mires a otra cosa sino a tu: Esposo y que todo te parezca que soy yo y que alli estoy yo, y no quieras gozar, oír ni ver cosa sin mí. Y esto harás trayéndome ante tus ojos siempre, como los que usan a sellar sus decretos y sus escrituras, que, porque nadie los pueda hurtar ni faltar el sello, lo traen siempre consigo en alguna ajorca del brazo o en alguna sortija de la mano, de manera que siempre vean su sello y nadie se lo pueda hurtar -porque la parte de nuestra persona que más presto y más a menudo vemos es ${ }^{713}$ las manos-. Y sabe, Esposa, que tengo razón de pedirte esto por(que) ${ }^{714}$ lo que he hecho por ti por causa dei amor tuyo que está dentro en mi, el cual es tan fuerte y me ha forzado tanto sin poderle resistir que la muerte (contra quien no vale defensa humana) no es más fuerte que el amor que yo tengo a ti; ha hecho este amor de mí todo lo que ha querido, como la muerte hace su voluntad con los hombres, sin ser ellos parte para defenderse de ella. Deseo también, Esposa, que me ames solo, sin amar a otro, así porque mi amor lo merece como por el tormento que reciben con los celos los que aman, como yo; que te certifico que no les es menos dura y gìve la imaginación celosa que la vista de la sepultura, y más fácilmente sufrirán que les digan 'en este sepulcro que está abierto te han de echar ahora luego' que si les dicen 'la que tú amas tiene otro amado'. Por eso, ten cuenta de amarme solo, así como solo lo merezco como por el encendido amor que te tengo".

Y, tornando el Esposo a hablar y recordar su amor debajo de esta figura de fuego y encendimiento, dice: "Las brasas de ese fuego amoroso que arde en el corazón son brasas de llama de Dios". Quiere decir: "Son brasas de vivisima y fuerte llama. Mayor y más ardiente fuego es este que el que acá se usa, porque el fuego de acá, con echarle un poco de agua, se mata; mas el fuego de amor vence a todas las aguas: echándole agua, arde más y se embravece; y no solamente muchos cántaros que encima se vaciasen no bastan [para] apagarlo(s) ${ }^{715}$, mas $^{716}$, aunque sobre él se derramasen todos los enteros ríos, de manera que cubriesen este fuego, no bastarían con todo eso que todo lo vence. Así que tan fuerte es el amor que no basta todo el poder de la tierra para vencerlo por fuerza, ni tampoco se quiere dejar vencer por dádivas y sobornos, porque no se abate a nada de eso el amor por su majestad; antes, afirmo que, si el hombre se quisiese rescatar del amor cuando el captiva ${ }^{717}$ a uno y le diese (que) todas cuantas riquezas y haberes [que $]^{718}$ en su casa tiene, aunque fuese muy rico, no se curaría el amor de ellas y despreciaría al que se las ofrecía con gran desprecio y le haría servir por fuerza. De manera que el amor es señor muy fuerte e implacable, que él ${ }^{719}$ ha tomado posesión en el

\footnotetext{
${ }^{712}$ Mas: equivalente a sino.

${ }^{713}$ Es: son

${ }^{714}(\mathrm{Que})$ : realizamos la supresión para evitar el anacoluto.

${ }^{715}$ Apagarlo(s): suprimimos el morfema de plural, pues este pronombre va referido a fuego.

${ }^{716}$ Mas: equivalente a sino.

${ }^{717}$ Captiva: cautiva.

${ }^{718}$ (Que)... [que]: corregimos la claramente errónea colocación del relativo. De nuevo nos apoyamos en el otro Comentario.

${ }^{719}$ Que él: en el Comentario según la letra leemos cuando, lo que da mayor sentido a la oración.
} 
corazón de alguno. Pues, siendo tal mi amor contigo, justo es que tú me respondas amándome con gran vehemencia y firmeza".

Esta que hemos visto es la sentencia de la letra, la cual se entiende de la misma manera espiritualmente; porque el eterno Esposo, después de justificada ya su Esposa, le pide que lo ame a él solo de todo su corazón, no mezclando su amor con cosa de la tierra sino procurando, deprendiendo y sabiendo las cosas de arriba ${ }^{720}$, considerando el divino [amor] que en él está ${ }^{21}$ para con ella, el cual es fortísimo, más que la muerte, como se ve por las cosas que le ha forzado [a] hacer y padecer este amor, las cuales bien tenía ella en la memoria [antes] que esta plática él comenzó, como ya vimos en los pasos [de] antes de estos. Por esta causa, es muy celoso El Esposo y le da gran pena, la tal Esposa suya que así está beneficiada de él ${ }^{722}$, que amase a otro. Le pide, pues, ser amado de ella con verdadero amor, cual es el suyo, declarando las propiedades de verdadero amor, $\mathrm{ni}^{723}$ solamente del que él tiene sino del amor en común, que es verdadero, es más abrasador que el mayor fuego del mundo, que mueve, incita y enciende vivamente los corazones a amar, y todas las aguas ni ríos, que son las tribulaciones, no basta[n] para apartar $\mathrm{el}^{724}$ amante del amor, ni tampoco todas las promesas y ofrecimientos de las dignidades y riquezas; que más precian su amor y lo que aman que a todo el mundo. Tal amor dice el Esposo que tiene a su Esposa y tal le pide. Un tal sentía[n] en sí ei Apóstol y los otros santos a quien[es] él escribía en esta misma sentencia, diciendo: ¿Quién nos apartará del amor de Dios? ¿Por ventura la afició[n], la angustia, la persecució[n], la hambre, el andar desnuidos, el pelejo o el cuchillo? ${ }^{725}$. Como está escrito: Por ti nos llevan a matar cada día, estamos como ovejas apartadas para el matadero; mas, sin todas estas cosas, vencemos, por aquel que nos amó; porque esioy cierto que ni la muerte ni la vida, ni los ángeles ni los principados ni los poderios, ni lo presente ni lo por venir ${ }^{726}$, ni lo alto ni lo bajo, ni ninguna otra criatura nos podrá[n] apartar del amor de Dios, que es en Cristo Jesús, único Señor ${ }^{27}$. Hemos traído todo este lugar del Apóstol porque es muy a propósito de nuestra exposición, y de gran consolación para los que lo consideran.

En la letra del vocablo infierno declaramos "sepulcro", porque así lo significa aquí y en otros muchos lugares, como en aquel de Jacob, descenderé al infierno ${ }^{728}$, que quiere decir:

\footnotetext{
${ }^{720}$ Esta idea se recoge, como señala el manuscrito en anotación marginal, en Carta a los Colosenses, 3. Concretamente, se trata de Carta a los Colosenses $(3,1-4)$

${ }^{721}$ El divino [amor] que en él está: parece un claro calco de un uso del verbo sum latino, el cual, además de los valores ser y estar, posee el de haber, que seria el más propio en este caso.

${ }^{722}$ La tal... de él: nos encontramos ante un fuerte desplazamiento, pues estas palabras son el sujeto de la proposición compietiva que después de ellas comienza.

${ }^{723} \mathrm{Ni}$ : y no. Actualmente, lo habitual es utilizarlo sólo cuando se trata de una negación múltiple.

${ }^{724}$ El: al.

${ }^{725}$ En el manuscrito, Carta a los Romanos, 8. Concretamente, se trata de Carta a los Romanos $(8,35-39)$

${ }^{726}$ Lo por venir: construcción de infinitivo sustantivada por el articulo neutro. Aún no funciona como un sustantivo propiamente dicho (con género masculino: el porvenir).

${ }^{727}$ En el manuscrito, salmo 43 (44). El titulo de este salmo es Canto de las desventuras nacionales.

${ }^{728}$ En el manuscrito, Génesis, 37 . Concretamente, se trata de Génesis $(37,35)$,
} 
"Esta desgracia de la muerte de mi hijo José me ha de acabar y llevar a la sepultura". Donde dice también llama[ra]da de Dios, declaramos "recia y fuerte llama", porque en la Escritura juntan el nombre de Dios a las cosas que quieren exagerar y encarecer, como "montes de Dios", "cedros de Dios", quiere decir "altísimos, crecidísimos cedros". Y, así, dice David al Señor: Tu justicia es como los montes de Dios ${ }^{729}$. Y de semejante decir usamos los españoles y otras naciones para ensublimar ${ }^{730}$ y engrandecer una cosa, que usamos del vocablo divino, diciendo "es un hombre divino", "tiene una divina elocuencia".

En la declaración espiritual ${ }^{731}$, dijimos que las aguas, cuya fuerza no bastaba para apagar la llama del amor, significaban las tribulaciones, y esta declaración es conforme al uso de hablar de la Escritura, como se ve por la autoridad del Apóstol que a este propósito trajimos, en el profeta que dice del Señor que lo había librado (y sacóme de muchas aguas ${ }^{732}$ ); y otros muchos lugares hay que significan lo mismo.

Hermana es años ${ }^{733}$ pequeña y tetas no ha $^{734}$ ella. ¿Qué le haremos ha nuestra hermana el dia que $e^{735}$ de ella se hablare? Si hay pared, edificarémosle un palacio de plata y su puerta fortalecerémosla para ella con tablas de cedro. Yo soy muro y mis pechos como torres. Entonces fui en sus pechos como aquella que halla paz.

Después que las mujeres están casadas y, por su parte, contentas con sus buenos esposos, les suele acudir nuevo cuidado de remediar y poner en $\operatorname{cobro}^{736}[\mathrm{a}]$ las hermanas menores que en casa de sus padres quedauan, y comienzan desde entonces a mirar por ellas y por su honra, y su Esposo les ayuda tomando por suyo el negocio de las cuñadas y procurándolas guardar y honrar hasta que las casen. Este mismo cuidado se le mueve ahora a esta contentísima Esposa y cuenta a su Esposo cómo ellos tienen una hermana tan pequeña y que ${ }^{737}$ aún no le han nacido los pechos, que es hermosa. Y, como quiera que la mayor está ya casada, ahora no se ha de hablar sino de la menor, que no faltarán nuevos enamorados para ella. Y, simple con la niñez, no terná valor para rescatarse y mirar por sí; por tanto, que mire qué la harán, cómo la ampararán para que ninguno se atreva a ofenderla. Y esto dice ahora la Esposa para más gloria de su Esposo, como luego veremos.

\footnotetext{
${ }^{729}$ En el manuscrito, salmo 35 (36). El título del salmo es Maldad humana y bondad divina.

${ }^{730}$ Ensublimar: sublimar: engrandecer, exaltar, ensalzar o poner en altura (DRAE, 1).

${ }^{731}$ Espiritual: en el manuscrito encontramos la abrevatura spual.

${ }^{732}$ Alusión biblica sin anotación al margen en el manuscrito. Salmo 35, titulado Maldad humana y bondad divina.

${ }^{733}$ Años: probablemente se trate de una confusión del copista, pues al principio del capitulo encontramos a nos (repárese en el parecido gráfico), sintagma -ya comentado- que resulta más conforme con lo que podemos encontrar en otras traducciones de este texto (además de ser igual a la del Comentario según la letra).

${ }^{734} \mathrm{Ha}$ : ver nota 683

${ }^{735}$ El dia que: el dia en que. Omisión de la preposición que debe acompañar al relativo en ciertas funciones circunstanciales. Uso extendido también actualmente.

${ }^{736}$ Poner en cobro una cosa: colocarle en paraje donde esté segura (DRAE)

${ }^{737}$ Tan pequeña y que: pareceria más lógico que estos dos elementos, en lugar de ir coordinados, fueran engarzados en una misma secuencia de carácter consecutivo.
} 
Hecha la pregunta ${ }^{738}$, responden ellos mismos, diciendo: "Será bien tenerla encerrada en un lugar que esté muy fuerte y será bien que, si se ha de hacer edificio de paredes, le hagamos una casa tan fuerte, $\tan$ maciza y lisa por defuera como si fuera de plata hecha, que ni la puedan quebrantar mirándola ni subirla trepando por ella. Y, cuando le hagamos la puerta, la guarnezcamos de muy fuertes y durables tablas de cedro para que, de esta manera, esté bien guardada nuestra hermana".

Estas palabras parecen ser dichas burlando, como si dijesen: "Si por vía de guardar lo hemos de hacer, hagámosla un palacio fortísimo, que no baste nadie a poder entrar donde ella está. Mas, en fin, todo esto no es menester. ¿Por qué no es menester, gentil Esposa?" Responde ella: "Si yo no estuviera casada con tal Esposo como tengo, tuviéramos necesidad de tratar de esos negocios para la guarda de mi hermana. Mas ahora, estando yo tan emparada ${ }^{739}$ con la sombra de mi Esposo, tan honrada con su nobleza y tan acatada por causa de su grandeza, no hay para qué tener a mi hermana encerrada de esa manera, sino traerla conmigo, junta a mí y abrazada con mis pechos, que no habrá quien ose $(a)^{740}$ decir una mínima ofensa. Porque no hay muro tan recio como yo ni hay torres tan recias como mis pechos; y esta fortaleza tengo yo en mí, para defender a quien a mí se llegare ${ }^{741}$, desde entonces, cuando yo comencé a agradar a mi Esposo y le parecí bien a sus ojos, que el comenzó a comunicarme su amor".

La hermana de la espiritual Esposa es la fe, aquella tanto preciada de Dios y que tanto él ama y que no hay cosa que mediante ella le pidamos, aunque sea más dificultosa que traspasar los montes, que nos sea negada. Esta es la hermana de la Iglesia, muy conjunta a ella y que mucho la ama; y, porque es simple y tierna, por causa [de] que no se funda en fuerzas de nuestros sentidos ni en cosas humanas, antes es muy más delicada cosa que todo lo que puede la grocesa de nuestro entendimiento alcanzar, y era en aquel tiempo del divino desposorio más tierna, cuando el hijo de Dios se desposó públicamente con su Esposa; pues $^{742}$ será bien que se vea cómo la podrán defender de los contrarios que tiene, que la persiguen y esto todas las bellezas que se hablare de ella para casarla para recibirla en matrimonio y juntar a los infieles que no la conocen.

Ponen primero los negocios y ofensas humanas para ver de qué valor son para defender la humana niñez de esta santa fe, y luego los deshechos como vanos y de gran fatiga y ningún provecho, porque no por vía de fuerza, no por riquezas ni humanos poderes ni por ambiciones ni por guerras ni contenciones se ha de llevar adelante el negocio de la fe, como lo muestra el Apóstol, probando que no escogió Dios los medios y caminos humanos para ensanchar su fe, sino solamente su Evangelio, por cuyos ministros instituyó [a] los más desechados que en el mundo tenía, porque no tenga la carne que presumir delante de Dios ${ }^{743}$. Pues, ¿por qué,

\footnotetext{
${ }^{738}$ Hecha la pregunta: construcción de participio absoluto.

${ }^{739}$ Emparada: amparada.

${ }^{740}(A)$ : no es habitual actualmente este uso prepositivo con el verbo asar.

${ }^{741}$ Llegar: allegar, juntar (DRAE, 9).

${ }^{742}$ Pues: retoma la construcción comenzada cuatro lineas más arriba $(y$, porque...).

${ }^{743}$ Romanos (1, 1-32).
} 
veamos, se defendará esta fe? Responde la Esposa: "Yo soy muro fortísimo y firmísimo, y mis pechos, que son los dos Sagrados Testamentos, son torres de gran fortaleza para defender la fe". Porque en la palabra del Señor está toda la firmeza para sustentación y defensa de la fe, y estos son los pechos de la Esposa. Y sola esta fuerza es bastante para defenderla y conservarla, sin ayuda otra ninguna de vanas maquinaciones y artes humanas. Y esta virtud está en la Esposa para la defensa de la fe, la cual virtud recibió desde el día que ${ }^{744}$ agradó a su Esposo y él se enamoró de ella, porque nunca faltó palabra de Dios en la Iglesia antigua ni en la de ahora.

Una viña tuvo Salomón en Baal-Hamón. Entregó la viña a las guardas; cada uno trae por el fruto de ella. Mil para ti, Salomón, y doscientos a los que guardan su fruto.

Después que las mujeres se casan con buenos y honrados maridos, para la sustentación de su familia es necesario que entiendan en $l$ legar ${ }^{74}$ y guardar la hacienda. $Y$, cuanto más honrada es la mujer y más amada a su marido, más cuenta tiene con esto, como claramente [se ve] en las postreras lecciones de los Proverbios $^{746}$ que a estos tales los favorece Dios con poner en ellos el cuidado que puede; $y$, [al] ejercitarse en buenas artes, cual es la agricultura, les da Dios frutos para cumplir las necesidades que en las familias le ofrecen.

Luego que esta Esposa se casó tan a su contento con su buen Esposo, comienza a tener cuidado de su hacienda y esperar (de $)^{747}$ haber gran provecho. Porque ella tiene muy buena viña, como arriba le oímos decir; $y$, como ahora está favorecida con su Esposo, ella tendrá gran cuidado de guardarla hasta que se coja el fruto y no habrá quien ose apartarla de guardar su viña, como de antes harían los hijos de su madre. Y, guardándola ella tan bien como persona que se duele por ser suya la viña, estará más entero el fruto y rentarle ha más. Y, para decir esto, usa de un argumento entero, y en esta manera: Salomón, el rey de Jerusalén, tiene una viña en aquel lugar que se llama Baal-Hamón que quiere decir "señorio de muchos", como si dijésemos, en el pago de muchas viñas. Y esta viña la arrienda Salomón a unos hombres para que la guarden y labren y traigan mil monedas de plata, del valor cierto de aquel tiempo, por el fruto de ella, y que ellos se ganen lo demás. Y, de aquí, concluye la Esposa que, por fuerza, habrá la su viña de rentar más que no la de Salomón, porque ella la guarda, que es propia señora, y estará mejor labrada que la otra, por no ser sus dueños y que no tienen tanta cuenta en labrarla y aderezarla como si fuera propria. Y dice: "Pues, si la tuya, Salomón, te renta mil a ti, y los que la arriendan y guardan ganarán por lo menos la quinta parte, que son doscientos; ¿qué me rentara la mía, de quien yo terné tanto cuidado?" Así se apareja la Esposa a la guarda de su viña, con esta buena esperanza que suele poner aliento a los labradores.

La viña de la espiritual Esposa es la congregación de los fieles que tiene a su cargo, como ya arriba vimos y como en muchos lugares de la Escritura se halla. Esta promete y propone (de) ${ }^{748}$ guardar muy bien, no como antes, que tenía tantos contradictores y tantos que de esta

\footnotetext{
${ }^{744}$ El dia que: ver nota 735 .

${ }^{745}$ Llegar: ver nota 741

${ }^{746}$ En el naanuscrito, Proverbios, 31 . Esta idea se desarrolla a lo largo de todo el capitulo.

${ }^{747}$ (De): como en casos anteriores, uso de la preposición de con el complemento de verbos transitivos.

${ }^{748}$ (De): como en casos anteriores, uso de la preposición de con el complemento de verbos transitivos.
} 
guarda la apartaban, $\operatorname{mas}^{749}$ el guardar más diligente, porque, después que Dios celebró estas santísimas bodas con su Esposa, ella está mucho más amparada que antes y no habrá quien la ose tocar. Y, guardando y labrando esta viña, también cierto es que ha de dar mucho fruto para su Esposo y que ha de haber gran provecho en las ánimas fieles, que son vides de esta viña, del cual fruto ella goza y su Esposo, porque de aquí resulta grande gloria y alabanza suya.

Estando tú en los huertos y los compañeros escuchando, haz que yo oiga tu voz. Huye, amado mio, que parezcas a la cabra montesa y al ciervecico sobre los montes de los olores.

La viña de la Esposa no estaba muy lejos de los huertos, como podemos colegir de lo que ella en el capítulo antes de este decía, convidando a su amado al campo: Levantarnos hemos de mañana y veremos las viñas y los huertos, etc. De manera que, estando ella en los huertos, podía ver y guardar su viña. Y, como el Esposo es pastor, le convenía entre día andar con su ganado. Y, así, el uno en el pasto y la otra en la guarda de las viñas se ocupaban, y en aderezar también algunas cosas del huerto, que esto competía a la Esposa. Y, como quiera que ambos se amen tanto, no querrían estar apartados uno de otro. Demás ${ }^{750}$ de esto, suele acaecer que, cuando dos están en gran conformidad de estrecho amor, nunca faltan envidiosos que les pese de ello, o porque ellos no tengan amores, o no tales, y cualquiera cosa y señal que ven pasar entre los buenos amantes les es enojosa y grave. $\mathrm{Y}$ de esto reciben gran gi sto los que mucho se aman, [porque] no solamente con estas muestras hacen pesar a los émulos, mas ${ }^{751}$ también se acrecienta su amor; que parece que el atizar del contrario los enciende más el amoroso fuego de sus corazones. Esto es lo que pasa en la letra presente, que el Esposo dice a su amada: "Cuando tú estuvieres en los huertos guardando las viñas y yo anduviere por el campo apacentando el ganado, por tu vida que algunas veces cantes alguna canción que pertenezca a nuestro amor, de manera que yo lo oiga y me goce mucho por ser tu voz, que tanto yo amo y los pastores que están ${ }^{752}$ escuchando revienten de envidia".

La canción que la Esposa dice para estos propósitos de mostrar el amor suyo y de su Esposo y hacer rabiar a los malos es la que está luego en la letra, que dice: "Esposo y mi amado, gran deseo tengo de verte. No estés mucho sin venir a visitar a tu Esposa; acude de cuando en cuando a verla y, cuando vinieres, no te estés en el camino sino muéstrame el amor que me tienes, no solamente en visitarme a menudo sino en venir más ligero que la cabra montesa y más que el ciervecico que anida en los montes espesos, donde hay cedros, terebintos ${ }^{753}$ y otras plantas olorosas. Porque bien sabes tú correr con gran ligereza, jno tardes!, jcorre!, amor mío verdadero, pues no puedo valerme sin ti; con gran presteza acude a verme".

\footnotetext{
${ }^{749}$ Mas: equivalente a sino.

${ }^{750}$ Demás: además.

${ }^{751}$ Mas: equivalente a sino.

${ }^{752}$ Según las formas verbales utilizadas en ei resto de la oración, dentro de la consideración de la acción como posible, lo adecuado aqui seria, en lugar de la forma están (de presente de indicativo), la forma estén (de presente de subjuntivo).

${ }^{753}$ Terebinto: arbolillo de la familia de las anacardiáceas, de tres a seis metros de altura, con tronco ramoso y lampiño; hojas alternas compuestas de hojuelas ovales, enteras y lustrosas; flores en racimos laterales y por frutos drupas pequeñas, primero rojas y después casi negras. Es comín en España; su madera, dura y compacta, exuda por la corteza gotitas de trementina blanca muy olorosa, y suele criar agallas de tres a cuatro centimetros de iargo (DRAE).
} 
Muchos émulos tiene el divino Esposo que no querría[n] que entre él y su Esposa hubiese paz ni concordia; antes, si pudiesen, se la desean ${ }^{754}$ quitar de su amparo y mando. Por esto, él le pide la voz de su cantar, en que le muestre su amor; y esta es un amargo y mortal tóxico para el gusto de sus envidiosos contrarios, cuales son el demonio y sus compañeros, y miembros los falsos profetas y de mal sembradores de cizaña. Tiene, pues, la fiel Esposa gran cuidado de publicar el amor que entre ella y su Esposo hay y coníesar que todo su bien le viene de él y que en su ausencia todo le es tristeza y angustia, y le ruega continuamente que no la olvide sino que siempre la visite, enviándolo ${ }^{755}$ su santo espiritu para corroborar, fortalecer y rehacer lo flaco que hay en ella. Y estc le pide y suplica siempre con grande instancia, $\mathrm{el}^{756} \mathrm{cual}^{\mathrm{la}} \mathrm{a}^{75}$ plega $^{758}(\mathrm{de})^{759}$ enviar en estos nuestros Esposos sobre la haz ${ }^{760}$ de la tierra, para que de ella huyan todas las tinieblas y vista el mundo de la divina luz. Y a Dios, nuestro Señor, que nos puede dar en gran demasía mucho de lo que pedimos, sea gloria y honra por los siglos de los siglos. Amen.

Fin de los Cantares de Salomón en el sentido espiritual ${ }^{761}$.

\footnotetext{
${ }^{754}$ Desean: lo habitual actualmente, según la forma verbal utilizada antes (pudiesen, pretérito imperfecto de subjuntivo), seria que apareciera aqui un condicional simple.

${ }^{755}$ Enviándole: más allá de los casos de loismo, este debe tratarse de un error, pues el pronombre se refiere a ella. Léase, por tanto, enviándole.

${ }^{756} \mathrm{El}:$ al

${ }^{757}$ La: se trata de un claro error, pues, más allá de los usos laistas, en este caso se trata de que este pronoinbre, que deberia ser masculino, pues es a él a quien tiene que placer el envio de lo que la Esposa le ruega.

${ }^{758}$ Plega: forma arcaica de presente de subjuntivo del verbo placer.

759 (De): uso de preposición con el infinitivo en función de sujeto.

${ }^{760} \mathrm{Haz}: \mathrm{faz}$

${ }^{761}$ Fin... espiritual: en el manuscrito encontramos lo siguiente:

"Fin de los cantares de Sa lomon en el sentido \& spual \&"
} 


\section{ÍNDICE}

INTRODUCCIÓN

página I

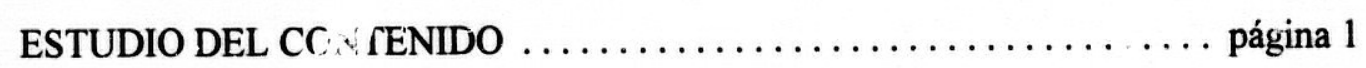

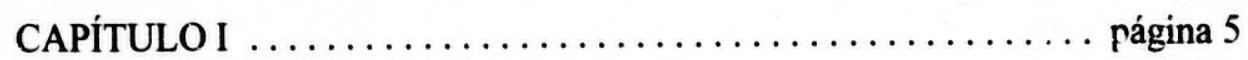

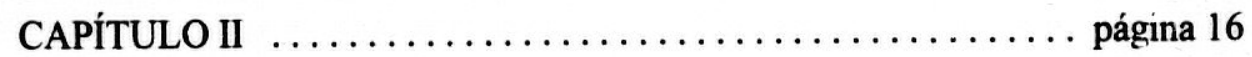

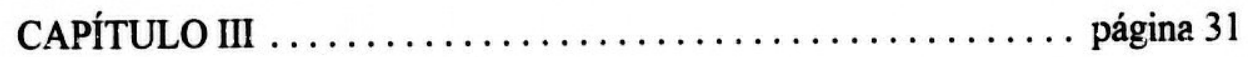

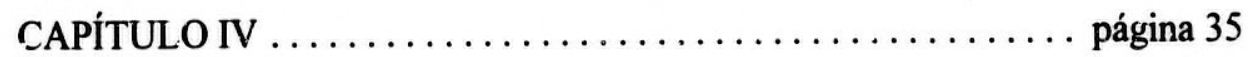

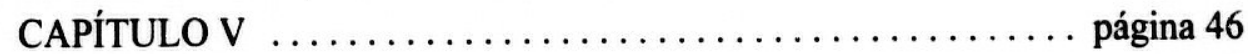

CAPÍTULO VI ............................. página 57

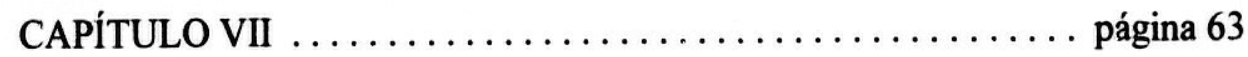

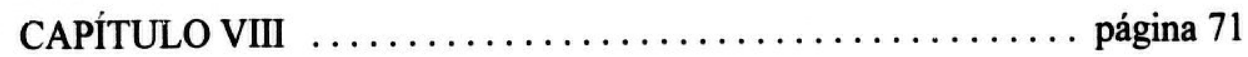

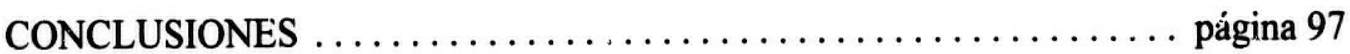

TEXTO L :

PROEMIO SOBRE LA EXPOSICIÓN

DE LOS CANTARES DE SALOMÓN POR EL PADRE

FRAY LUIS DE LEÓN SEGÚN EL SENTIDO ESPIRITUAL . . . . página 102

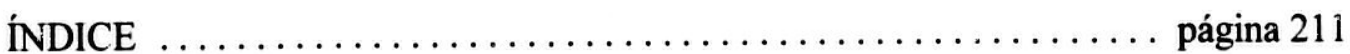

